\title{
'Incidental' Ethnographers
}




\title{
Studies in Christian Mission
}

\author{
General Editor \\ Marc R. Spindler (University of Leiden) \\ Editorial Board \\ Heleen Murre-van den Berg (University of Leiden)
}

VOLUME 33 


\section{'Incidental' Ethnographers}

French Catholic Missions on the

Tonkin-Yunnan Frontier, 1880-1930

by

Jean Michaud

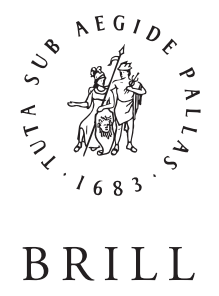

LEIDEN • BOSTON

2007 


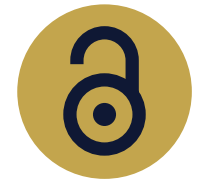

This is an open access title distributed under the terms of the CC BY-NC-ND 4.0 license, which permits any non-commercial use, distribution, and reproduction in any medium, provided no alterations are made and the original author(s) and source are credited. Further information and the complete license text can be found at https://creativecommons.org/licenses/by-nc-nd/4.0/

The terms of the cc license apply only to the original material. The use of material from other sources (indicated by a reference) such as diagrams, illustrations, photos and text samples may require further permission from the respective copyright holder.

On the cover: Father André Kircher (1863-1922) in Chinese attire among Miao (Miaotse) converts in Yunnan, photographed by his friend Paul Vial, undated. Source: MEP Archives

Relevant illustrations are reproduced with the permission of La Société des Missions Etrangères de Paris.

This book is printed on acid-free paper.

ISSN 0924-9389

ISBN 9789004139961

(C) Copyright 2007 by Jean Michaud. Published by Koninklijke Brill NV, Leiden, The Netherlands.

Koninklijke Brill NV incorporates the imprints Brill, Hotei Publishing, IDC Publishers, Martinus Nijhoff Publishers and VSP.

All rights reserved. No part of this publication may be reproduced, translated, stored in a retrieval system, or transmitted in any form or by any means, electronic, mechanical, photocopying, recording or otherwise, without prior written permission from the publisher.

Authorization to photocopy items for internal or personal use is granted by Koninklijke Brill NV provided that the appropriate fees are paid directly to The Copyright Clearance Center, 222 Rosewood Drive, Suite 910, Danvers, MA 01923, USA.

Fees are subject to change.

PRINTED IN THE NETHERLANDS 


\section{CONTENTS}

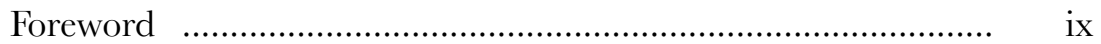

Acknowledgements …………........................................... xi

List of Illustrations …...................................................... xiii

List of Maps ….................................................................. xvii

PART ONE

SETTING THE SGENE

Chapter One Missionary Ethnographers In and Around

Tonkin .......................................................................

Introduction ……............................................................ 1

The New Dialogue Between Missionaries and

Anthropologists ………...................................................... 6

Why French Upper-Tonkin and Yunnan? …….................... 14

Structure of the Book ........................................................... 17

Chapter Two Upland Northern Vietnam .............................. 19

The Northern Highlands in the Late Imperial Era …......... 22

Under French Rule .......................................................... 26

Peoples of Upland Tonkin Towards the End of the

19th Century ……......................................................... 28

The Situation Today …………………………………........ 35

PART TWO

COLONIAL ETHNOGRAPHY AND THE FRENCH HERITAGE

Chapter Three French Ethnography in New France ............ 43

New France 1534-1763, A Seminal Field of Missionary

Ethnographic Practice for France ……………………...... 43

Sagard, Lafitau, and Brébeuf ............................................ 48

The Colonial Heritage .......................................................... 59

Chapter Four Focusing Upon the Catholic Colonial

Missionary Towards the End of the 19th Century ............... 65 
The Catholic Missionary ………............................................ 67

On the Relevance of Biographies …………….................... 81

PART THREE

\section{UPPER TONKIN}

Chapter Five Early Contributors to the Ethnography of

Upper Tonkin

The First MEP Publications from Upper-Tonkin

Publications by 19th Century Explorers, Diplomats and

Military Observers

Chapter Six Missionary Colonial Expansion and the

Upper Tonkin Vicariate

Missions and the Colonial Project in Tonkin

Establishment of The Upper Tonkin Vicariate

Missionaries in the Highlands

Lull and Decline

PART FOUR

\section{MISSIONARY AUTHORS AND THEIR TEXTS}

Chapter Seven Missionaries and Their Texts ……................. 131

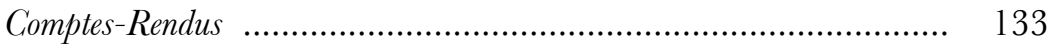

Religious Publications ...................................................... 139

The Special Case of Anthropos ……….................................. 141

Chapter Eight The Works of Missionaries Liétard, Vial,

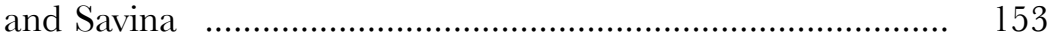

Alfred Liétard and Paul Vial Among the Lo-lo .................... 153

François Marie Savina and 'His' Miao ................................ 167

A Life of Savina ……..................................................... 168

The Disciplinary Hypothesis ........................................ 181

A Word on Savina's Dictionaries ......................................... 183

Savina's Ethnographic Publications .................................... 185

Inside Histoire des Miao .................................................... 186

On Savina's Legacy ............................................................ 203

Conclusions …................................................................. 211

Chapter Nine Rivalry, Avoidance, and Scientific Longing ..... 213

Lacking Knowledge and Failing Memory …….................... 219 
Missed Opportunities and the Republican Obstacle 224 Finale

Bibliography 235

Illustrations and Maps 247

Index 271 
Jean Michaud - 978-90-47-42021-7

Downloaded from Brill.com๑4/26/2023 $\odot 9: 56: 23 \mathrm{AM}$

via free access 


\section{FOREWORD}

This book combines an interest in colonial history, French Catholic missions in and around northern Vietnam, and textual analysis. However, it is not the work of an historian, nor a missiologist, nor a literary specialist. In more ways than one, this study is a typical anthropology work. Arguably, anthropology can at times be described as a generalist discipline in the social sciences, never shy to mine neighbouring fields for their riches, from botany to philosophy. Anthropologists love to assemble multiple elements in eccentric jigsaws transgressing disciplinary boundaries. This book does just that while studying production of missionary ethnography on the highland minorities of northern French Indochina and southern Yunnan.

This book is thus situated at the junction of a number of established fields. But to this day, the texts explored in the next pages have largely been left unaddressed. Why? Because the place (on the margins of colonial Indochina), the peoples (mountain minorities), and the texts (penned by 'amateurs') all pertain to a subsidiary universe that, some would argue, was and remains of little historical, political, economic, and intellectual consequence.

It is true that practically all of the men who will take the front stage in the nine chapters that follow have remained minor historical characters, and that the fruit of their intellectual work, had it known the good fortune to be published, was not judged worthy of much interest by the specialists of the era. If I chose to devote a book - and a few years of my life - to them, clearly, it is because I challenge that label of inconsequentiality. As do a growing number of historians, linguists, and anthropologists today. My hope is that this constitutes only a first step to stimulate colleagues in a number of fields to dig deeper into the rich and original textual legacy of the authors brought to light here. 
Jean Michaud - 978-90-47-42021-7

Downloaded from Brill.com๑4/26/2023 $\odot 9: 56: 23 \mathrm{AM}$

via free access 


\section{ACKNOWLEDGEMENTS}

Financial support for the background research and the completion of this book was provided, over several years, by the Economic and Social Research Council of the United Kingdom, the British Academy of the United Kingdom, the Canadian Social Sciences and Humanities Research Council, and the Fonds Québécois de la Recherche sur la Société et la Culture. Academic institutions I have been linked to during the gestation of this book have all provided facilities, these are the University of Hull (UK), the University of Otago (New Zealand), and in Canada, Université de Montréal and Université Laval.

This book owes a lot to the intellectual contribution of many colleagues and friends. Though naming them all is an unrealistic task, a few ought not to remain anonymous: my partner and colleague Sarah Turner for decisive contributions at every stage of the book's production, Desmond Manderson and Jackie Adcock for intellectual inspiration and constant encouragement, journal editors Bruce Lockhart and Colin McKerras for their important inputs to earlier versions of Chapters 5 and 6, Yves Goudineau and Bénédicte Brac de la Perrière for the chance to test my ideas with the participants to their graduate seminar at École des Hautes Études en Sciences sociales in Paris, and Agathe Larcher-Gosha and Christopher Gosha for insightful suggestions. Especially, I would like to thank Brian Heenan, Margaret Swain and Frédéric Laugrand for their helpful comments on earlier versions of the manuscript.

Father Gérard Moussay and Brigitte Appavou at the archives of Société des Missions étrangères de Paris, Lucette Vachier from Centre des Archives d'Outre-Mer in Aix-en-Provence, and staff of the documentation centre of École française d'Extrême-Orient in Paris have all earned my gratitude for their highly competent and dedicated assistance while searching archival material in France. Father Moussay's gracious permission to include previously unpublished MEP photographs to this book is particularly appreciated.

Canadian graduate students François Fortin-Deschênes, Claire Tugault-Lafleur, Caroline Goulet, Marise Lachapelle and Priscilla Taché have all helped in skilfully preparing and putting together various parts of the manuscript. Laura Schoenberger has shown great patience and competence editing a final version of the text. Merci à toutes et tous! 
And finally, series editor Marc Spindler, and Brill staff Mattie Kuiper and Ingeborg van der Laan, have been unfailing supporters of this project from its early stages and their diligent efforts have made the burden of delivery almost painless. 


\section{LIST OF ILLUSTRATIONS}

1. Execution of MEP Bishop Pierre Borie (1808-1838) in Don-hoi (Tonkin), September 24, 1838. This colour painting is shown in the Martyr Room at the MEP Seminary in Paris, and is exemplary of the 19th century movement for the emulation of young recruits.

2. The Pavie Mission team in Xieng-Hung, c. 1891. The picture includes Auguste Pavie himself in the center under the flag, his protégé Pierre Lefèvre-Pontalis in a white shirt on the right, and White Thai leader Deo-van-tri, second left from Pavie. Source: Lefèvre-Pontalis, 1902.

3. Father Léon Girod (1854-1924) with Kinh converts, 1885. Photographer unknown. Source: MEP Archives.

4. Missionaries of the West Tonkin vicariate at their annual retreat. Undated, c. 1885. 1. Paul-Marie Ramond (1855-1944), who will become the first Vicar Apostolic of Upper Tonkin in 1895; 2. Pierre Gendreau (1850-1935), who will take over the West Tonkin vicariate at the death of Bishop Puginier in 1892; and 3. Léon Girod. Source: MEP Archives.

5. Paul François Puginier (1835-1892), Evếque de Mauricastre in partibus, Vicar Apostolic of West Tonkin from 1868 until his death. Undated, c. 1890, probably in Hanoi. Source: MEP Archives.

6. 1895-P.-M. Ramond photographed in Hanoi when he was ordained Évêque de Linoë in partibus. Vicar Apostolic of Upper Tonkin from 1895 to his resignation in 1938. Source: MEP Archives.

7. "État des Missions du Tonkin Occidental et du Haut-Tonkin depuis le 15 juin 1894 jusqu'au 15 juin 1895"- Statistics on the state of the West and Upper Tonkin vicariates, dated October 27, 1895. These two vicariates are listed here as having respectively 2 Bishops for 43 missionaries, and 1 Bishop for 12 missionaries. This list was part of the first annual comptes-rendus from the newly established Upper Tonkin. Source: MEP Archives.

8. "Compte-rendu de l'exercice 1896-1897." Annual report from the Upper Tonkin vicariate written by Bishop Ramond, dated September 11, 1897. The Bishop reports for that year 18 missionaries and 11 native priests for a population of 2.9 million. Source: MEP Archives. 
9. Paul-Marie Ramond (1881), Léon Girod (1879), Antoine Bourlet (1898), Alfred Liétard (1896), and François-Marie Savina (1901) each photographed in Paris just prior to their departure to Asia. Source: MEP Archives.

10. Father Aloys Schotter (1857-1924), top centre in the back row, smoking a long pipe, in his boys' school of Lanlong, western Guizhou. This picture was taken the year of his death. Fung Yut Hin, photographer. Source: MEP archives.

11. Paul Vial (1855-1917) dressed as a Lolo, with two Lolo converts. This undated picture appeared on the cover of his 1905 book, Yun-Nan Nadokouseu grouping articles previously published in Annales de la Société des Missions-Etrangères.

12. 1895-Lou-mei-y, eastern Yunnan. Residence of Father Paul Vial, possibly his 'château' of St-Paul-la-Tremblaye. Photograph (fragment) by Paul Vial. Source: MEP Archives.

13. Father André Kircher (1863-1922) in Chinese attire among Miao (Miaotse) converts in Yunnan, photographed by his friend Paul Vial, undated. Source: MEP Archives.

14. White Miao women in eastern Yunnan. Undated photograph by Paul Vial. Source: MEP Archives.

15. Paul Vial's "Dictionnaire Français-Lolo”, 1909.

16. First page of an article on the Lolo of Yunnan by Paul Vial in Les Missions Catholiques, 21 September, 1888. The picture is also from China but is not connected with the article.

17. Peu-méo (Hmong) girls in upland Tonkin in the late 1910s, from Maurice Abadie's Les races du Haut Tonkin de Phong Tho à Lang-Son, 1924. Photographer unknown.

18. French soldier interacting with a Hoa-méo (Hmong) woman, PaKha (today Bac Ha), northern Tonkin, late 1910s. Photographer unknown. Source: Abadie 1924.

19. Le bateau de 1901-The 1901 ship. Representative group photograph taken in the gardens of the MEP Seminary in Paris, with the 45 recruits (a very successful year) about to board a ship to Asia. In circle is François-Marie Savina (1876-1941), the future author of Histoire des Miao (1924). Source: MEP Archives.

20. Father F.-M. Savina among the Miao (Méo, Hmong) in Tonkin. Undated, c. 1920. Source: Savina 1924.

21. 1920-F.-M. Savina at age 44 in Xieng-Khouang (Tranninh), northeast Laos, during the two years he was detached to the colonial troops sent to tame a Méo rebellion. Savina stands with his Nung 
personal assistant (centre) and a Miao leader (left). Source: Savina 1924.

22. The missionaries of Upper Tonkin meeting in Hung Hoa on June 30, 1924, for their yearly retreat. 1. Bishop Ramond; 2. Léon Girod (who fell ill the night this picture was taken and died 9 days later); 3. F.-M. Savina (age 48) the same year he published Histoire des Miao; 4. G. Vandaële, who would succeed Ramond in 1938 as Vicar Apostolic of Upper Tonkin. Source: Bulletin de la Société des Missions-Étrangères de Paris, 1924.

23. F.-M. Savina (top left), at age 58, with colleagues in Hong Kong, 1934 (fragment). Just back from a year in France, Savina was starting a 5 year stay in Hong Kong to put together his Guide linguistique de l'Indochine française (1939). Source: MEP Archives.

24. 1938 - F.M. Savina (circled) still at the MEP house in Hong Kong writing his multilingual dictionary. Source: MEP Archives.

25. North face of the MEP St-Joseph Minor Seminary in Ha-thach, Upper Tonkin vicariate. The seminary was destroyed, along with the buildings of the vicariate's see in Hung Hoa, during the First Indochina War (1945-1954). Undated. Source: MEP Archives. 
Jean Michaud - 978-90-47-42021-7

Downloaded from Brill.com๑4/26/2023 $\odot 9: 56: 23 \mathrm{AM}$

via free access 


\section{LIST OF MAPS}

Map 1. General area of interest

Map 2. Principal locations today

Map 3. Northern Vietnam - Provinces and topography, 2006

Map 4. Tonkin: Military Territories (1903) and Vicariates (1896)

Map 5. Mission du Tong-King occidental, by Adrien Launay, 1889

Map 6. Carte schématique pour l'Histoire des Miao, F.-M. Savina, 1924 
Jean Michaud - 978-90-47-42021-7

Downloaded from Brill.com๑4/26/2023 $\odot 9: 56: 23 \mathrm{AM}$

via free access 
PART ONE

SETTING THE SGENE 
Jean Michaud - 978-90-47-42021-7

Downloaded from Brill.com๑4/26/2023 $\odot 9: 56: 23 \mathrm{AM}$

via free access 


\title{
CHAPTER ONE
}

\section{MISSIONARY ETHNOGRAPHERS IN AND AROUND TONKIN}

\begin{abstract}
We submit that, in order to follow up on [Talal] Asad's admonition to study the location of anthropology in the colonial encounter, it is necessary to free the study of colonial ethnographies of disciplinary bias and to treat them sui generis, not in thrall to an academic idea. ${ }^{1}$
\end{abstract}

\section{INTRODUGTION}

The purpose of this book is twofold. From the very start of its planning stages it was to introduce an English speaking audience to a particular body of ethnographic literature produced by Catholic missionaries at the time of French Indochina. This body of literature is still largely unknown to non-French speakers - and to a majority of French speaking anthropologists alike. From this initial and relatively modest aim, I also wanted to pursue a complementary, more critical objective, that is to weigh up these ethnographic writings by assessing the intellectual context of their creation and the methods by which they were produced. This objective is important so that we can discuss their potential validity today in the turmoil of ongoing debates regarding ethnography as text.

Over the last few decades, the number of anthropologists examining missionary contributions to ethnography has grown, evident in mounting numbers of publications. In the broader Asian context, these published works take many forms, from James Clifford's Person and Myth: Maurice Leenhardt in the Melanesian World, published in 1982 in which Clifford discussed the contribution the French Protestant missionary made to New Caledonia's ethnography as well as to anthropology in general, to Albert Schrauwers' analysis of the work of Dutch pastor Albert C. Kruyt among the To Pamona of Indonesia in his Colonial 'Reformation' in the Highlands of Central Sulawesi, Indonesia, 1892-1995 published in 2000.

${ }^{1}$ Pels, Peter and Oscar Salemink (eds). Colonial Subjects: Essays on the Practical History of Anthropology. Ann Arbor: University of Michigan Press, 1999, 7.

(C) JEAN MICHAUD, 2007 | DOI 10.1163/9789047420217_002

This is an open access chapter distributed under the terms of the CC BY-NC-ND 4.0 licensemichaud - 978-9๑-47-42021-7 
One should also note the many scholarly dissertations, articles and book chapters taking a similar path, an excellent example being Margaret Byrne Swain's "Père Vial and the Gni-p'a. Orientalist Scholarship and the Christian Project" published in 1995.

However, in comparison to the vast majority of these earlier publications, this book takes a distinct stance. It does not concentrate on a particular individual's life and work. Its focus, instead, is at a broader scale, concerning a group of missionaries brought together by chance, geography and time. Will this mean that disparities between such an eclectic assembly of authors and their texts may exceed potential similarities? Possibly, but this does not overly worry me. My point is that these single men - and they were all men - were actors in the same play, the plot of which was the expansion of France's grandeur to the Orient. In the minds of these actors, the playwright was God Himself. Not surprisingly however, in the minds of the French colonial administrators in Indochina, the script was instead in the hands of the conquering Third Republic, dictated by its economic interests and craves for prestige. The primary, and perhaps the most ubiquitous tension underlying the actions and the writings of missionaries in Tonkin, was thus triggered by the differing agendas of the religious and republican institutions. At times in relative harmony with each other, sometimes paying no attention to the other's actions, and more than occasionally outright conflicting, this marked stress between religious and republican ideals and desires in Tonkin will constitute the backdrop, the trope of this book. We will see the effects rippling down the power hierarchies to influence even the hesitant prose of the humblest messenger of the Lord labouring in His fields.

Yet, merely presenting these early works would hardly be satisfactory as a scholarly undertaking. Discussing and analysing them is another objective of this book. The intellectual context of the production of colonial ethnographies at the turn of the 20th century has to be scrutinised if one hopes to assess these works for what they actually meant, and why they were completed. What is colonial ethnography? Who performed it? In what frame of mind? What methods did the early 'researchers' use? How did all these questions materialise in French Indochina? To answer these questions, I have decided to focus on the earliest embodiment ethnographical research took in Indochina, namely, that performed by individuals ingrained in segments of the colonial apparatus (as opposed to research that was later to be conducted by trained ethnographers under the auspices of the École française d'Extrême- 
Orient). The early ethnographers who will be presented and discussed in this book were either missionaries, administrators or military officers, all belonging to the spearhead of a colonial system in the process of taking over an ancient civilisation and its frontiers.

It has been observed in various contexts of European colonial expansion that explorers, administrators, the military and missionaries constituted, in practical terms, the first Western ethnographers.

In 1953, Meyer Fortes wrote that it is characteristic and important that anthropological studies owe a great deal to enthusiasts from outside the academic world, to officers of the Crown, to missionaries, traders and travellers. In France, Maurice Leenhardt was an important missionary presence among anthropologists, while in Austria and Germany, Father Wilhelm Schmidt and his journal Anthropos, started in 1906, made an important impact on behalf of his congregation, the Missionary Society of the Divine Word. Yet, histories of anthropology do not usually consider missionary anthropologists and when they do, their missionary background is thought to be of no importance. The importance of the administrative background is illustrated by the fact that in Britain, Cambridge anthropology owed a lot to the Orientalist and administrator Sir Richard Temple, and that as late as 1953 Meyer Fortes succeeded to a Cambridge professorship which was handed down by two former members of the Indian Colonial Service, T.C. Hodson and J.H. Hutton. Malinowskian functionalism could not have established itself without the support of missionaries like J.H. Oldham or administrators like Lord Lugard. [...] These cases indicate the importance of non-academic influences on the establishment of academic anthropology. ${ }^{2}$

Two categories in particular, the missionaries and the military officers, probably due to their relatively long residence in contact with local populations, as opposed to the generally shorter visits paid by explorers and colonial administrators, have undoubtedly produced a durable legacy of empirical and methodological approaches to the Other which is still of value today. In many cases, and despite definite biases dictated by the epochs and the ideologies with which these early observers were associated, their legacies are highly valuable as first hand observations of populations, some of which have since disappeared. Not only because of the importance and the relevance of these legacies, but also because they are highly relevant to the French Upper-Tonkin case, it is the publications and correspondence of missionaries that form the bulk of the

${ }^{2}$ Pels, Peter and Oscar Salemink. "Introduction: Five Theses on Ethnography as Colonial Practice." History and Anthropology, vol. 8, nos. 1-4, pp. 1-34, 1994, 4. 
ethnographic works presented and analysed in this book. Hundreds of documents, indeed thousands of pages, exist and wait to be analysed while perhaps an even larger number has not yet been made available to the research community. Nevertheless, enough is obtainable to fully justify attempting to understand, analyse and interpret it.

While it has often been argued that missionary writing is of disputable scientific interest, this literature nonetheless forms a body of direct observations that should not be shunned, especially in view of the paucity of ethnographic information available on isolated ethnic groups at the time of European colonization. I argue that studies of Peninsular Southeast Asian highland ethnicity today cannot afford to ignore this rich, though disparate assortment of views from the past.

It is not possible here to review all of the archival material on hand regarding upland northern Indochina and Yunnan and as a consequence, a selection of texts will be addressed. I have selected these texts based on four key criteria: their qualitative and quantitative importance, the competence of their authors, the conditions under which they were produced, and their value in supplying material for a discussion on ethnography in the French colonial context. I give particularly prominent authors more space with additional biographical data, providing details regarding their intellectual formation, a major factor in the performance of their ethnographic work. For each of these figures, a major piece of work will receive extra attention.

\section{The New Dialogue Between Missionaries and Anthropologists}

Are academic anthropologists today ready to approach colonial missionary ethnography with an open mind? Certainly more than they ever were in the past. Along with a growing number of authors making a case in favour of acknowledging the contributions of non-academic ethnographers to anthropology, I am of the opinion that studying the texts of 'incidental' ethnographers such as missionaries is of great value for the discipline. As Guiart succinctly put it: "There is still, in missionary archives, a wealth of material waiting to be analysed, if the anthropologist had been trained to make use of it instead of brushing it aside as tainted with bigotry." ${ }^{\prime 3}$ Pels and Salemink also clearly voice

\footnotetext{
${ }^{3}$ Guiart, Jean. "Comments on Stipe." Current Anthropology, vol. 21, no. 2, pp. 170-1, 1980,171
} 
their support for this option, arguing that "an essential methodological move in the study of the history of anthropology needs to be made: the dialectical one of accounting for the extra-academic and extradisciplinary influences on the constitution of the discipline". ${ }^{4}$ Studying missionary writings in the context of colonial northern Vietnam constitutes a step in that direction.

Over colonial times, professional anthropologists and missionaries were able to largely ignore one another or keep out of each other's way for as long as the colonial enterprise provided a logical division between their respective roles. It is a telling symptom that open and frank debates between Western anthropologists and Christian missionaries only took place on a significant scale from the late 1970s onwards, after the colonial era was over. Facing superb indifference, even hostility as shown by a number of British academic anthropologists, ${ }^{5}$ the missionaries long considered the academic ethnographers as intruders and unconcerned intellectuals whom, they believed, spent just enough time with their subjects to produce a report or a thesis, giving locals little in return. Academics on the other hand, saw in the missionaries incompetent and moralistic hordes focused on normalizing the natives, causing their cultural and, often, material demise. ${ }^{6}$

Precursors to a dialogue could be found on both sides of the fence, ranging from Rivers in 1920, Smith in 1924, Westermann in 1931, and Junod in 1935, to Nida in 1959 and 1966, Luzbetak in 1961, and Miller in $1970 .^{7}$ All have indeed questioned the perceptions of anthropologists

${ }^{4}$ Pels and Salemink. "Introduction", 3.

${ }^{5}$ Cf. Delfendahl, Bernard. "On Anthropologists versus Missionaries." Current Anthropology, vol. 22, no. 1, pp. 89-90, 1981; Abbink, Jan. "Anthropology and the Missions: A Critical Epistemological Perspective." Methodology and Science, vol. 18, pp. 254-70, 1985.

${ }^{6}$ On occasions in this book, the word 'natives' with inverted commas, sometimes without, will be used in consistency with the colonial terminology. The same applies to 'tribe' and 'tribal', 'savages,' and a few additional terms associated with the colonial era. This should by no means be interpreted as a promotion of those terms.

7 Rivers, W.H. "Anthropology and the Missionary." Church Missionary Review, vol. 71, pp. 208-15, 1920; Smith, E.W. "Social Anthropology and Missionary Work." International Review of Missions, vol. 13, pp. 518-31, 1924; Westermann, Diedrich. "The Missionary as an Anthropological Fieldworker." Africa, vol. 4, pp. 164-77, 1931; Junod, H.P. "Anthropology and Missionary Education." International Review of Missions, vol. 24, pp. 213-28, 1935; Nida, Eugene A. "The Role of Cultural Anthropology in Christian Missions." In Readings in Missionary Anthropology II, ed. Smalley, W.A., South Pasadena: W. Carey Library, 1978 [1959]; Nida, Eugene A. "Missionaries and Anthropologists." Practical Anthropology, vol. 13, pp. 273-7, 287, 1966; Luzbetak, L.J. "Towards an Applied Missionary Anthropology." Anthropological Quarterly, vol. 34, pp. 165-76, 1961; Miller, 
regarding missionary work and thus have made attempts to breach the unity of an overall and all-powerful condemnation of missionary 'ignorance' and 'ethnocentrism' by senior scholars in academia. ${ }^{8}$ Such a dominant anti-clerical front had prevailed to the point of profoundly negatively influencing the curriculum in universities, as Trouwborst recalled in the Leiden of the late 1940s. ${ }^{9}$

In the meantime, over the 20th century, without needing in any way to wait for an elusive seal of approval from academia for their work in the field, missionaries took the initiative to publish their ethnographic observations in an array of forms including novels, diaries, children's books, religious journals, annual reports, travelogues and articles in various kinds of magazines, many of them aimed at members of the public at large. A more formal branch of the missionary world also officially entered the select field of academic anthropology through the creation of the academic journal Anthropos in 1906. For a century, this successful journal has promoted the ethnographic work of Christian missionaries by offering them a serious venue for publication, as well as a medium that has contributed to sharpening their intellect and acquainting them with the current debates they could measure their own reflections against. Anthropos has earned a right to sit on university library shelves next to academic anthropology journals. Elsewhere, some missionaries have entered the academic field to the point of playing influential roles within higher education institutions. Frenchman Maurice Leenhardt, who started his career as a Protestant missionary in New Caledonia where he spent two decades, was offered upon his return to France the Marcel Mauss chair at the École des Hautes Etudes en Sciences Sociales. When Leenhardt died in 1954, that chair was then passed on to the young Claude Levi-Strauss.

As was just mentioned, the post-colonial rapprochement between the two dedicated groups of lay and religious modern ethnographic

E.S. "The Christian Missionary: Agent of Secularization." Anthropological Quarterly, vol. 43, no. 1, pp. 14-22, 1970.

${ }^{8}$ Such a statement is necessarily sweeping, only aiming at indicating what was the general state of mind among professional anthropologists of the colonial period. Exceptions, or at least moments of exception, also existed, for instance when Lowie spoke in defence of Father Wilhelm Schmidt, whom he assessed was unfairly criticised. Fittingly, Lowie declared "... let him that is without bias cast the first stone." Lowie, Robert H. The History of Ethnological Theory. New York: Rinehart \& Co., 1937, 193.

9 Trouwborst, A.A. "Missionaries and Ethnography." In The Ambiguity of Rapprochement. Reflections of Anthropologists on their Controversial Relationship with Missionaries, eds. Bonsen, R., H. Marks and J. Miedema, Nijmegen: Focaal, pp. 32-44, 1990, 33. 
fieldworkers took place 30 years ago. ${ }^{10}$ Following several seminal individual contributions, the landmark was an article published in 1980 by anthropologist Claude Stipe in the academic journal Current Anthropology, starting a three-year debate that had just been waiting to happen, an exchange of views that helped, as one commentator put it, "to bring an important issue out of the anthropological closet." That debate was then quickly followed by substantial works by Clifford in 1982, Whiteman and Salamone in 1983, and Abbink in 1985, and the road to a mature discussion was resolutely opened. ${ }^{11}$ This involved multiple voices, as was illustrated by the remarkable book The Ambiguity of Rapprochement. Reflections of Anthropologists on their Relationship with Missionaries, edited in 1990 by Bonsen, Marks and Miedema, in which authors assessed the legacy of decades of reciprocal suspicion and investigated with intellectual honesty the common grounds where the two sides, vividly aware of their primary differences, could nevertheless safely discuss issues of mutual interest. ${ }^{12}$

Peter Pels wrote in 1990 that a systematic study of the historical relations between missionaries and anthropologists had yet to be produced, and I personally do not know of any having been published since this statement was made over 15 years ago. Such lack is symptomatic. ${ }^{13}$ Pels also explained in a concise way why, in his view, anthropologists and missionaries were both professionals 'on a mission', although the exact meaning of these words proved to be more complex than expected. Limits between these two universes are more blurred than one would like, with considerable overlap:

During the professionalization of anthropology, anthropologists' missions have often been directed, not at the mission areas of the Christian

${ }^{10}$ Cf. Salamone, F.A. "Anthropologists and Missionaries: Competition or Reciprocity?" Human Organisation, vol. 36, no. 4, pp. 407-12, 1977.

${ }^{11}$ Clifford, Person and Myth; Whiteman D. and F. Salamone (eds). Missionaries, Anthropologists, and Cultural Change. Williamsburg: William and Mary College, Studies in Third World Societies nrs. 25 \& 26, 2 volumes, 1983; Abbink, "Anthropology and the Missions."

${ }^{12}$ Bonsen et al., The Ambiguity of Rapprochement.

${ }_{13}$ Pels, Peter. "Anthropology and Mission: Towards a Historical Analysis of Professional Identity.' In The Ambiguity of Rapprochement. Reflections of Anthropologists on their Controversial Relationship with Missionaries, eds. Bonsen, R., H. Marks and J. Miedema, Nijmegen: Focaal, 1990, 81. This absence of course has not precluded individual anthropologists and missionaries from getting together and further reflecting on the issue from their particular vantage points, as illustrated in 2004 with the proceedings Anthropologie et missiologie: $X I X^{e}-X X^{e}$ siècles: entre connivence et rivalité, eds. Servais, Olivier \& Gérard van 't Spijker, Paris: Karthala, collection Mémoire d’Églises, 2004. 
missionaries, but at the Christian missionaries themselves. In doing so it meant that these anthropologists had to endorse - be it passively - the civilizing mission in which the Christian missionaries participated. ${ }^{14}$

One of the unquestionable consequences of the progress made during this recent debate, is that it is now not only possible, but also desirable for anthropologists to go back in time and re-assess the legacy of missionary ethnographers with a fresh eye. This, they must do devoid of emotional rejection and also without the resistance created by a long period of uncomfortable proximity. Academic anthropologists, as a group, have matured and as Petersen wisely put it, it has recently become possible to acknowledge that:

we all rely upon [the missionaries'] documents; we are all familiar with and lament the changes they have had a hand in; and we are all acquainted with one or another of wise and humane men and women who serve in the missions there today. Fools and charlatans are there as well, but most of my colleagues manage to discriminate among them. ${ }^{15}$

The recognition of non-professional contributions to institutionalised anthropology has therefore occurred against the will of many, and this resistance has not always been with the best intentions. To a large extent, the professionalization of fieldwork in British anthropology depended on the tactical disparagement of both missionary and administrative ethnographies. ${ }^{16}$ Yet, at the same time, we now know that early modern anthropologists like Malinowski succeeded in their seminal fieldwork research because of major ground work having already been conducted on location by earlier explorers, traders, administrators, and Christian missionaries. As stated by Stocking,

Anthropology needed the missionaries. The shift from the amateur ethnographer to the professional fieldworker, embodied by people like Franz Boas, A.C. Haddon, W.H.R. Rivers and W.B. Spencer, was not possible without the help of the missionary ethnographers in the field. ${ }^{17}$

14 Pels, "Anthropology and Mission," 81.

${ }_{15}$ Petersen, Glenn T. "Comments on Stipe." Current Anthropology, vol. 21, no. 2, 1980, 173

${ }_{16}$ Pels and Salemink. "Introduction."

${ }_{17}$ Stocking 1983:74-76, rephrased by Pels, Peter. "Anthropology and Mission: Towards a Historical Analysis of Professional Identity.' In The Ambiguity of Rapprochement. Reflections of Anthropologists on their Controversial Relationship with Missionaries, eds. Bonsen, R., H. Marks and J. Miedema, Nijmegen: Focaal, 1990, 83. 
Indeed, in his preface to The Nuer, E.E. Evans-Pritchard made this connection explicit by thanking:

the staff of the American Mission at Nasser, of the Congregation of Verona at Yoahnyang, and the Church Missionary Society at Ler, [with] particular acknowledgement to the staff of the American Mission, [...] who unreservedly placed their home, their time, and their knowledge at my disposal. ${ }^{18}$

Acknowledging this debt may seem sensible and relatively harmless to younger generations of anthropologists today. But it was far from obvious early in the 20th century. Even when administrators or missionaries happened to also be trained ethnographers, the professional anthropologists of the time were reluctant to acknowledge their work, let alone give them credit.

Colonial missionary ethnography was, for the most part, conducted by non-specialists for whom this activity was accidental in the course of their apostolic mission. In this sense, I call them 'incidental ethnographers.' The preference I give here to the word 'incidental' instead of the more neutral equivalent 'accidental,' may appear to suggest that such ethnography could be of a lesser value. This is not the case. In this context of course, 'incidental' between inverted commas is meant as an irony pointing at the contempt institutionalized anthropology has held for a long time for non-professional ethnographers and their texts.

To make sense of their writing, we need to consider these 'incidental' ethnographers and their work individually, as well as their historical, cultural, and political circumstances. Throughout colonial times, a few dozen French Catholic missionaries were first-hand witnesses and gatherers of information regarding the highland populations living beyond the Red River ${ }^{19}$ delta in what constitutes today northern Vietnam, northeastern Laos, and the south of Yunnan province in China. Yet, while a handful of published missionary texts from these individuals were later found to be of use to academic anthropologists, linguists,

${ }^{18}$ Evans-Pritchard, Edward E. The Nuer. A Description of the Modes of Livelihood and Political Institutions of a Nilotic People. New York and Oxford: Oxford University Press, 1971 [1940], p. vii.

${ }_{19}$ As a matter of lexical concordance with the documents and archives used to write this article, place names, people's names, and ethnonyms will be spelt as in the original texts unless an English equivalent is widely used, in which case the latter will be preferred (such as Red River in place of Fleuve Rouge). 
and historians, little is known of the actual circumstances of their production in the field. Clerical prose produced within the missionary apparatus humbly collects dust in religious archives; most pieces that were published in missionary journals have gone largely unnoticed, while rather modest attention has been paid to a few essays that appeared in more established media. In this book, I want to offer a glimpse into some of this neglected ethnographic literature.

But, one might ask, with a variety of French colonial authors having left ethnographical texts on the populations dwelling in the highlands of Tonkin, why should the missionaries be of singular interest? The answer is: Because they were observers at the forefront meeting with and producing texts on the 'savage' Other. And these representatives of Europe and Christianity were active in the colonies on a continuous basis for far longer than any other category of Western observers.

Case studies by authors such as Pels and Foster have emphasized that missionary texts actually constitute a specific form of ethnography, undertaken in unique conditions rarely matched by current anthropologists, most strikingly with regards to the embeddedness of the outside observer in the host society. This new relativism has contributed to toning down, even to leaving behind, the all-pervasive and one-sided representation of the near-wicked clergymen among the 'natives.' To its credit, such hostility focused on the very real contradictions inherent to missionary work in the colonial setting, and on the cultural damages caused to host societies by over-zealous missionary practice and ideology. Yet at the same time, such dismissals also sadly deleted any valuable contributions these early observers could have made, and this is precisely what is being corrected to a degree in this book. ${ }^{20}$

Curiously, during colonial times, French academic anthropologists remained somewhat on the margins of this historical dismissal of missionaries, being noticeably less vocal than their British colleagues about the vices of missionary work in the field. This low-key attitude was linked to a series of factors. In addition to the fact that the practice of ethnography remained separated from the discipline of ethnology for longer than elsewhere, a point to which we will return, one dominant

${ }^{20}$ See discussions in Huber, Mary T. The Bishops' Progress. A Historical Ethnography of Catholic Missionary Experience on the Sepik Frontier. Washington and London: Smithsonian Institute Press, 1988; Comaroff, J. and J. Comaroff. Of Revelation, and Revolution: Christianity, Colonialism, and Consciousness in South-Africa, vol. 1. Chicago: University of Chicago Press, 1991. 
factor was that French missionaries in the colonies were usually unmarried Catholic priests. ${ }^{21}$ In French colonial history, this allowed many Catholic missionaries to play a long-term spearhead role in the colonial venture. They took roots in remote settings for decades on end, setting themselves up in a prime position for gathering intelligence on little accessible locations, infiltrating coveted countries and societies, learning the natives' customs and languages and diffusing them afterwards, and acting as cultural as well as political interpreters, often brokers of the colonial take-over. ${ }^{22}$ As a consequence, French academics have acknowledged earlier and more freely than their British and American colleagues the contributions that missionary work and texts have made to anthropology. Important administrative successes and also great ethnographic works owe a debt to the use of archives collected by generations of missionaries. ${ }^{23}$ In the next chapter, I will expand on the reasons for this difference in the appreciation of their work, which lie in the specifics of the French Catholic missionary institution. In Indochina, in their role as actors in a multi-layered historical drama, French Catholic missionaries were bound together by a very unique mindset instigated by the combined ideological forces of their era - the Third Republic in France, and missionary politics - and religious traditions and institutions - here chiefly those of the Société des Missions Étrangères de Paris. While searching for traces of this ideological imprint and in order to read between the lines of written archives, I will at different stages detail the particularities of each author, including their intellectual genealogy, and combine such individual histories with an understanding of what was occurring in the local surrounds. I do this to be able to answer the important questions: who? when? how? and, crucially, why?

\footnotetext{
${ }^{21}$ To disentangle the sometimes byzantine debates associated with the exact definitions of the terms 'Catholic' and 'Roman Catholic', I take in this book a conciliatory approach by which both terms will be used as alternative names for the entire Christian Church governed by the Pope. The word 'Catholic' alone - in contrast with 'Roman Catholic' used in the British/US tradition, which is needed there to distinguish the English Catholic and Anglican traditions - is used in harmony with the French autonym: l'Église catholique de France, the Catholic Church in France.

${ }^{22}$ Leiris, Michel. "L'ethnographe devant le colonialisme." Les temps modernes, vol. 6, no. 58, pp. 357-74, 1950.

${ }^{23}$ Mauss, Marcel. "L'ethnographie en France et à l'étranger." La Revue de Paris, vol. 20, pp. 537-60, 815-37, 1913, 829.
} 


\section{Why French UpPer-Tonkin and Yunnan?}

One could argue without encountering much resistance that northern Vietnam, or colonial Tonkin, shared many similarities with other regions of the world colonized by Catholic conquerors such as Africa, Brazil, Mexico, the Philippines before the 1890s, and French North America prior to the British conquest. Indeed, a similar book could be written on any of these locations. The choice of Tonkin is due to five key reasons. First, it is triggered by my personal interest and experience in that region and its populations - another illustration, if ever it was necessary, of the inherent subjectivity of anthropological inquiry. But clearly, this familiarity argument alone does not suffice to make this place a suitable scene for a study such as the one conducted in this book. There are also tangible features that make colonial Tonkin, and particularly Tonkin's uplands, and nearby southeast Yunnan especially suitable for this inquiry into Catholic missionaries and their ethnographic legacy. Allow me to review them briefly.

The significant Catholic presence in Tonkin, like the French colonial presence as a whole, was neatly circumscribed in time. Prior to the 1880s, the sheer difficulty in accessing the northern high region meant that the first French testimony on the northern mountain regions and their inhabitants had yet to be produced, with the exception of a handful of explorers such as Jean Dupuis, who limited their observations to river valleys. Leaving aside the events in 1873 when Francis Garnier briefly held Hanoi and its environs, the French presence in Tonkin spanned from the start of the formal military conquest in 1883 to the Geneva agreements of 1954. In the mountainous section of the new Tonkin protectorate, the time period of missionary activity was even shorter. This began in 1891 with the establishment of a military administration along the Chinese border and lasted until the start of the First Indochina War in 1946, which marked the retreat to Hanoi of most of the missionaries attached to the uplands. Within this timeframe, by the early 1930 s, the most serious ethnographical publications on the northern highlanders had appeared, that is, after François-Marie Savina's Histoire des Miao and Maurice Abadie's Les races du Haut-Tonkin de Phong Tho à Lang-Son were published in the mid-1920s. From that moment to the official launch of the First Indochina War, security issues had largely subsided in the upper reaches of Tonkin, the pax gallica had been firmly installed on the China frontier, and everyday administration of populations had become a routine actively geared towards the fullest 
possible exploitation of economic resources - mise en valeur, as the French euphemistically called this operation. Therefore, all that was published on the uplands and its inhabitants after the 1930s essentially repeated earlier publications, with the notable exception of infantry officer Henri Roux's Quelques populations du Nord Indochinois ${ }^{24}$ much cited in English mainly because it was published in 1954 at the start of the American involvement in Indochina. The book was in fact based on its author's memories and field notes from investigations conducted in the 1920s while he commanded the 4th and the 5th Military Territories.

Nevertheless, between the 1880s and the 1930s, an impressive amount of ethnographic observations, linguistic surveys, and analyses were produced by independent, administrative, military, and missionary observers - the third key reason as to why this book focuses upon them. This sheer volume of work in itself arguably places this particular region among the most intensely researched in terms of the general ethnography of 'tribal peoples' of the whole French colonial empire. In particular, the military officers posted in the Tonkinese high region were prolific authors, leaving in their wake major ethnographic inquiries rivalling the missionaries' contribution. A fair number got published, such as, and in addition to Abadie and Roux just mentioned, Émile Lunet de Lajonquière's two famous versions of the same research, Ethnographie des territoires militaires in 1904 and Ethnographie du Tonkin septentrional in 1906, Émile Diguet's Les Montagnards du Tonkin published in 1908, and Auguste Bonifacy's dozens of articles released between 1902 and $1930 .^{25}$ A great many such reports also remain in archives and thus, have never made it into the public eye. It is not possible here to study these military texts, as that would require another book entirely. Yet, their contribution will be felt in several ways here, sometimes simply because missionary authors had a chance to read these accounts prior to writing their own observations, at other times because their paths crossed, some missionaries having congregated with officers during their postings in the highlands and having had the opportunity to discuss their thoughts.

${ }^{24}$ Roux, Henri (Colonel). "Quelques populations du Nord Indochinois." France-Asie, vol. 92-93, 1954.

${ }^{25}$ Just to mention a few publications by this prolific author: Bonifacy, Auguste Louis-M. (capitaine d'infanterie coloniale). "Contes populaires des Mans du Tonkin." BEFEO, vol. II, pp. 268-79, 1902. "Monographie des Man Quan-coc." Revue Indo-Chinoise (30 novembre), pp. 726-34; (15 décembre), pp. 824-32, 1904. Ethnographie de l'Indochine. Vietnam, Cambodge, Laos. Hanoi-Haiphong: Imprimerie d'Extrême-Orient (Gournement Général de l'Indochine), 1919. 
The fourth important reason why upper Tonkin and its immediate periphery constitute a fertile field of inquiry for our purpose relates to the Vatican's Congregatio de Propaganda Fide, the Congregation for the Propagation of the Faith, the Roman arm responsible for actively spreading the Catholic faith throughout the world. This reason dovetails more precisely with the Vatican's strategy in East Asia of assigning only one missionary society to work within the limits of a given vicariate - the see of a Vicar Apostolic, equivalent to a diocese. This constituted, so to speak, an exclusive licence to convert within that particular territory. ${ }^{26}$ This exclusivity, in turn, lead to a homogeny among the priests sent to harvest souls with regards to language, culture, ideology, and intellectual preparation. Thus, in the largest part of Tonkin's highlands, one single Catholic missionary congregation was granted the right to proselytise, the Société des Missions Etrangères de Paris (MEP), the Paris Society of Foreign Missions. The only exceptions were the provinces and Military Territories east of the Clear River and the lower Red River that were part of different vicariates assigned to Spanish missions by Rome in the late 17th century. Conveniently for us, Yunnan and northern Laos were also organised in formal vicariates attended by MEP missionaries. A welcome consequence of this homogeny today is that while devoting most of our attention to the Upper Tonkin vicariate case, political borders will not stop us from considering the texts of neighbouring missionaries in other MEP vicariates when appropriate. For instance, I argue that it is justifiable to include here the work of, among others, Paul Vial in southern Yunnan and Antoine Bourlet in eastern Laos, because their institutional background, their relationships to the local populations, their administrative circumstances, their conception of their ministries, and their ethnographic writings are very much comparable.

Fifthly and finally, Tonkin's highlands are again on the international agenda of anthropological research thanks to the recent political liberalization in Vietnam, Laos and China. There may never again be another opportunity like this one, when a large concentration of minority peoples - millions of them-speaking dozens of distinct

${ }^{26}$ Following a strategy made necessary after many historical setbacks throughout the world, the Congregation for the Propagation of the Faith in Rome (often called the Propaganda Office) nominated bishops abroad as vicars apostolic, heading new missionary territories where no formal ecclesiastical organisation had been erected before and where local authorities were reluctant to let such an installation occur. These 'floating' bishops held symbolic titles in partibus, which bore the names of ancient vicariates (such as Mauricastre) that had been abandoned or were in places no longer Christian. 
languages, is suddenly available to be observed, studied, and understood better by outsiders. This clearly justifies the current high level of ethnological interest in the Mainland Southeast Asian massif and its populations. ${ }^{27}$

\section{Strugture of THE Book}

The seemingly eclectic structure I chose to give this book calls for an explanation. The volume is divided into four parts with nine chapters in total and the development of the argument does not follow a linear path. The current chapter sets the scene by asking questions about the logic of the study and the rationale of the topics addressed in the next chapters. Chapter 2 completes this introduction by concisely presenting the populations in northern Vietnam who were subject to missionary ethnography, with a portrait of their situation today. The circumstances on the Chinese side of the border have not been included as they would have required a significant supplement. For our purpose here, we can argue that southeast Yunnan and southwest Guizhou, where some of the ethnographers analysed in Chapters 7 and 8 were posted, offer a general situation comparable to that in northern Vietnam in terms of ethnicity and the history of Catholic missions.

The two chapters forming Part II - Colonial Ethnography and the French Heritage, paint a historical background to the development of ethnography as conceptualised and practised in France. Thus, in Chapter 3, I build a foundation for a comparative evaluation of the missionary ethnographic production from northern upland Indochina. The early experience of French Catholic missionary ethnography performed during France's expansion in Canada in the 17th and 18th centuries is used to establish that point of comparison. Chapter 4, then, summarises the particulars of the formation and life of the French Catholic missionary in the late 19th century and contributes to explain why, in the reflection on individual missionaries' text to ensue in Part IV, biographical information on each author is needed.

Part III-UpPer Tonkin, takes us to the field in the highlands of colonial northern Vietnam. In Chapter 5 are first surveyed the ethnographic texts of religious and secular authors who were active in

${ }^{27}$ Michaud, Jean. Historical Dictionary of the Peoples of the Southeast Asian Massif. Lanham: Scarecrow Press. 2006. 
that region before the establishment of the Upper Tonkin vicariate in 1895. The religious texts are in direct relation with our object; secular authors, however, are also important because they generated a wealth of information available to those who walked in their footsteps. Entirely devoted to the creation, life, and decline of the Upper Tonkin Vicariate over its fifty years of existence, Chapter 6 sets the political stage on which missionary ethnographers posted among the highland minorities performed.

Part IV-Missionary Authors ANd theIr Texts is a critical presentation of ethnographic texts produced by variously talented missionary authors working in the southern portion of the Southeast Asian Massif. Following a short biographical introduction for each author, their main works are presented and discussed. One of these, a monograph, is contemplated in more details from the point of view of its ethnographic context. Thus, Part IV is divided in two. Chapter 7 deals with 'minor' authors who came on the scene early and illustrates the most widespread type of missionary writing on the 'natives.' In Chapter 8, three more gifted and prolific authors are paid special attention: Alfred Liétard and Paul Vial, both writing from Yunnan, and François-Marie Savina, in the Upper Tonkin vicariate, arguably the most prolific author the Missions Étrangères de Paris ever dispatched to northern Vietnam. Accordingly, he is apportioned the lion's share of Chapter 8. A romantic, perplexing author, Savina was a phenomenal ethnographer.

In Chapter 9, the conclusion, I discuss the ambivalent intellectual relations missionary ethnographers in southern portion of the Mainland Southeast Asian massif developed with each other and with secular scholars as well as colonists. I attempt a characterization of their prose based on their intention as author, and the chapter brings the book to a close with a discussion of the favourable and adverse conditions which determined their actions. 


\section{CHAPTER TWO}

\section{UPLAND NORTHERN VIETNAM}

This chapter is a general introduction to colonial highland Tonkin and its populations intended to set the cultural background of the ethnographies presented in this book. It begins with an outline of the history of the northern highlands from imperial times to French colonial rule. A picture is then drawn of the highland ethnic situation during the French watch, using the French ethnic categories. Finally, the situation as it stands today is exposed, this time using the official Vietnamese categories. This last section gives a measure of the demographic significance of the region and the 5 million or so mountain dwellers found today in this part of northern Vietnam.

The Red River delta and its mountainous periphery correspond, by and large, to the former French protectorate of Tonkin. It is a fanshaped territory centred on the capital city, Hanoi, which sits at sea level, with a gradual altitude increase as one proceeds along the rays of the fan. At its highest point, close to the Chinese border, this territory peaks at just over 3000 metres.

Today, the ethnic diversity there compares with what it was when the French arrived in the late 19th century, and the locations where the various ethnic groups dwell have remained largely unchanged. This is not to say though, that these ethnic groups have always inhabited the area. History and archaeology tell us that of the actual indigenous societies of northern Vietnam, very little remains. The bulk of the lowland population today is formed of Viet migrants who arrived from China a few centuries B.C. The Proto- and Deutero-Malay migratory waves that preceded the Viet have been virtually wiped off the lowlands and the coastal areas and pushed to the highlands where they are still represented today by Austronesian and Austro-Asiatic speakers. Then, in the highlands, came the Tibeto-Burman and the Tai-Kadai speakers from central-eastern China between 1000-2000 years ago on their way to today's Thailand. Over the last five centuries came the Miao-Yao speakers, that is, the Yao and, within the last 300 years, the Hmong. Any such substantial in-migrations practically ceased with the closure of the international borders when the French took over Tonkin in the 
1880s, quickly followed by territorial and population control even in the remotest parts of the Annam Range.

Prior to the late 19th century, archives in Vietnamese and Chinese languages or what has been written about them in English or French, show very few traces of these politically minor peoples, except when addressing ad hoc administrative and trade problems, whilst modern historians such as Lê or Ngo rarely touch on them. ${ }^{1}$ Without significant home-grown written records produced by these highland societies and without a sufficient number of decisive archaeological studies, what is left of their early history in upper northern Vietnam is scarce.

Since the foundation of the early lowland kingdom of Van Lang in Vietnam in the 7th Gentury B.C., interactions with the hinterland and the kingdoms to the north and the west, beyond the Vietnamese portion of the Southeast Asian massif, were either defensive when an attack was launched, offensive when a neighbour was to be subsumed, or commercial in times of peace. By the start of the second Lê dynasty in the 15th century A.D., nearly all of the Black River (Sông Đà) catchments and part of the upper Red River (Sông Hồng) bore the generic label of Hưng Hóa, while Thâp-châu was the name for the 10 châu of An-tây prefecture, covering a large portion of the remaining area on both sides of the Sino-Vietnamese border. Sub-prefectures bore either the name of huyen or châu. In the huyên, the head was a mandarin sent from Hanoi; in the châu, indigenous chiefs were kept in place, reporting directly to the provincial governor. In a way, one could say that ethnic differences were thus known, yet as long as the state's objectives were met in terms of taxation and military draft in the châu, the ethnic identity of the local leader was considered irrelevant.

In his study of Vietnamese public institutions in the 18th century, Dang stresses that at the time, the northern frontier and the peoples inhabiting it were, at least nominally, under the responsibility of the Vietnamese Ministry of the Armies (Binh Bô). The peripheral and mountainous districts they occupied still bore the names châu and huyên.

${ }^{1}$ Lê Thàn Khôi. Histoire du Viêt Nam des origines à 1858. Paris: Sudestasie, 1981 [1971], 40-7. Ngo Gia Van Phai Unification du Royaume sous les Lê. Paris: Ecole française d'Extrême-Orient, 1996. For an account of the preserved pre-19th century Vietnamese archives, see Dang Phuong-Nghi, Les institutions publiques du Viêt-Nam au XVIII ${ }^{e}$ siècle, 1969, pp. 23-31. See also an early Chinese account in Ma Touan Lin, Ethnographie des peuples étrangers à la Chine, 1883, a 13th century text translated from Chinese and annotated by Marquis d'Hervey de Saint-Denys. 
But both were now administered by $\mathrm{Kinh}^{2}$ mandarins sent to live on location, called respectively Tri-huyên and Tri-châu. In the northern region in the 18th century, there were 44 such highland châu and 163 lowland huyen, which indicate that a fairly large proportion of the territory was actually still classified as remote. Due to the larger proportion of Kinh population in the huyen, it can be assumed that the system worked more smoothly in these districts than in the more distant châu. Ultimately, at its maximum extension, this system's only remaining purpose was to locate existing villages, administer the census for military draft and corvées purposes, and try to tax the population in proportion to the surface of terraced rice fields they owned. Consequently, the long settled and agriculturally very active groups closer to the Delta like the Tai ${ }^{3}$ speakers and the Muong were fairly heavily burdened while all the remoter and more mobile groups in the mountains, like the Miao-Yao speakers, practising dry rice cultivation on swiddens, largely escaped direct state control. ${ }^{4}$

But who exactly were the inhabitants of these highlands during precolonial history? Were they the same as those met by the French from the mid-19th century onwards? Very little evidence has been uncovered to provide a satisfactory answer to these questions. Historian Nguyên Thê Anh states that until the 17 th century the montagnards ${ }^{5}$ in the upper catchments of the Red River Delta were generically called Man without further distinction, as was also the case in large parts of southwest China. ${ }^{6}$ The Vietnamese state control in the region was limited to administrative and military centres along the main river and land routes leading into China. It did not control the vast mountain ranges

2 'Kinh' is used here as a convenient shortcut to designate the lowland Vietnamese, whom we can also call 'Viet'. No further ethnic distinction amongst the lowland population will be made in this book.

Unlike the official listing in Vietnam today, but in accordance with the official Vietnamese linguistic classification of National Minorities, all the groups belonging to the Tai language sub-family, when addressed collectively, will be called Tai in this text.

4 Dang Phuong-Nghi. Les institutions publiques du Viêt-Nam au XVIII ${ }^{e}$ siècle. Paris: École française d'Extrême-Orient, 1969.

5 In accordance with French colonial archives and publications, the French term 'montagnards' - with lower-case ' $m$ ' - is meant here to include all the highland populations in Tonkin as well as in the rest of French Indochina. In this book, I use it interchangeably with other equivalents such as 'highland populations', 'upland groups', 'mountain minorities', etc.

6 Nguyen The Anh. "L'image de la piraterie tonkinoise dans la litterature coloniale." In Rêver l'Asie. Exotisme et litterature coloniale aux Indes, en Indochine et en Insulinde, ed. Lombard, Denys, Paris: École des Hautes Etudes en Sciences Sociales, 1993. 
separating these routes. The border zone was more akin, in the minds of the lowland powers, to a "no man's land."7

\section{The Northern Highlands in the Late Imperial Era}

We turn now to an examination of the general conceptions of the mountainous north and its populations by the lowland powers in the 19th century, firstly by the Imperial Vietnamese, and then by the arriving French colonists.

In the north-western highlands, more precisely in the upper valley of the Black River, the Thái town of Muang Lai, today's Lai Chau, is known to have existed since at least the Mongol invasions in the late 13th century, with the loose federation of Sip Song Chau Tai, the Twelve Tai Cantons, later formalised around it. Paying tribute to Luang Phrabang at certain times, to Burma or China at other times, it was eventually brought under Hue's influence. Hue, the Nguyên dynasty's stronghold, had become the new capital of Vietnam at that time. Nguyên Anh, also known as Emperor Gia Long, established modern Vietnam in 1802 and convinced China, its overlord, to acknowledge its new form, including the mountainous areas in the north.

In turn, when he visited these highlands in the late 1880 s, French diplomat Auguste Pavie briefly described the feudal society there, and stated that he had no doubt that the Sip Song Chau Tai were dependent on the Court of Annam (as Hue's government was known to the French). ${ }^{8}$ Not only the Tày (then called Thô) in the Clear River (Sông Lô) area closer to the Delta, but also the Thái of the Black River valley were paying tribute to Hue. Abuses by the state under the Nguyên in the 19th century caused more than 400 registered rebellions against the regime. At least one of these rebellions involved montagnards in the north in a bold act of opposition to the state. ${ }^{9}$ In addition, the Taiping uprising in China (1851-1864) pushed Chinese gangs into Upper Tonkin where they harassed the montagnards in the Thái Nguyên region. At the same time, famines struck mercilessly.

\footnotetext{
7 Nguyên "L'image de la piraterie," p. 67.

${ }^{8}$ Pavie, Auguste. A la conquête des coeurs. Paris: Presses Universitaires de France, $1947,125$.

${ }^{9}$ Lê Histoire du Viêt Nam, 383.
} 
A systematic study on the history of the highland minorities in Vietnam would require that the documents prepared and published under the Nguyên be seriously scrutinised in search for clues on the highland populations that dwelled on the margins. Gia Long's Nhât thông du-dia chi (General Geography) for instance was completed in 1806. In this work, the principal roads of the Vietnamese Empire were described along with the limits, the main produce and the cultural customs of each province. Gia Long's son, emperor Minh Mang, initiated in his time the production of the Dai Nam liêt truyên (Biographies of Dai Nam) which chiefly included information about the aristocracy and the great people of the Empire, but also famous rebels, some of whom might have been from non-Kinh ethnicity and living in the mountains. Emperor Tu-duc next produced over 1865-1882, in several volumes, what Lê Thành Khôi has labelled the best work on the geography of Vietnam, the Dai Nam nhât thông chi. ${ }^{10}$ Among many other dimensions, this monumental work informs for each province on the populations and famous local historical figures. Also potentially useful for the north is the Dong-Khánh Dia-du chi lúoc produced in 1886 by Huynh Huu Xúng, which includes several maps noting the details of the recent expansion westwards under Minh Mang. ${ }^{11}$

But for our purpose here, a briefer assessment will have to suffice. Drawing upon many 19th century writings in his research on the history of Vietnam before the French, Lê Thành Khôi provides useful additional information about the highlands in that century. ${ }^{12}$ He notes that under Emperor Gia Long, the central government ministerial structure that was active under the Lê dynasty had been maintained, now controlled by six ministries. In administrative terms, the northern region was granted the right to a distinct political existence (Bac Thành) and state pressure was kept to a minimum there for several years in order not to fuel the anti-Nguyen feeling in a population that had long been connected to the Lê, whom the Nguyen had overthrown. During this early period of unified Vietnam, Bac Thành had 13 tran, or provinces

10 Ibid., 357-8.

11 See also Quach-Langlet, T. "Le cadre géographique de l'ancien Campa." Actes du séminaire sur le Campa, Université de Copenhague, le 23 Mai 1987, pp. 28-48, Paris: Travaux du Centre d'Histoire et Civilisations de la Péninsule Indochinoise, 1988. p. 29.

${ }^{12}$ Lê, Histoire du Viêt Nam, 345-84. 
(renamed tinh under Minh Mang). The tran were divided in phu, prefectures, themselves sub-divided in huyên (for the lowlands) and châu (for the mountains) as was the case prior to this new administration, then in tông (cantons), and in $x \tilde{a}$ (communes). As in the 18th century, the cantons and communes were granted particular autonomy and were administered by local chiefs co-opted by local prominent men, subject to provincial scrutiny. Historian Lê Thành Khôi does not give the number of provinces in the north nor does he name them or give the precise location of those incorporating the mountains. Only one clue is given upon discussing the rules of draft for soldiers, when he mentions "the ten 'exterior' provinces were inhabited by mountain peoples." 13

If we are to believe the general map provided by Lê Thành Khôi ${ }^{14}$ which shows the extension of Vietnam under Minh Mang (1820-1841), it appears that the official inclusion of the northern mountains into the empire extended only to the mid-region, the foothills and the midvalleys of the rivers flowing from the north, a region essentially populated by Tai speakers. Even within the controlled mountainous region, it is probably safe to assume that the higher reaches and the populations dwelling there were not very solidly attached to the central state. It is more likely that the Tai speakers, already traditionally in contact with the higher up populations, were acting as middlepeople between the very high region and the delta. Knowledge of these elusive montagnards of upper Tonkin by the Viet was probably filtered through the feudal Tai, and no Viet felt they really needed to know much more than that to conduct the affairs of the state efficiently. Nevertheless, imperial Vietnamese military parties would occasionally be dispatched into the northern mountains to restore order when caravans and trading posts were threatened by banditry. This occurred especially in the second half of the 19th century when wandering rebel groups appeared en masse, pushed out of the Chinese periphery by insurrectional movements in Yunnan and Guangxi.

The town of Lào Cai ('Old Market' in quan hoa), for example, a rudimentary settlement and trading post conveniently located on the banks of the upper Red River at the Yunnan border, known to have existed since at least the 17th century, was not under direct Vietnamese control. It was observed by French adventurer and trader Jean Dupuis

13 Ibid., 348.
14 Ibid., 365. 
in the 1860s that armed groups of Cantonese merchants were installed in Lào Cai. ${ }^{15}$ Even though such merchant parties also conducted some local trade with montagnard dwellers, ${ }^{16}$ this local trade was only marginal compared with the long haul circulation of merchandise between Yunnan and the Delta.

Beyond the general administrative expansion of the state, what exactly was the Hue policy towards the montagnards prior to the French takeover? Was it structurally different from the political and economic dependency in which the Hue court, its mandarins and their local representatives, kept the peasants of the Red River Delta? Probably not. We know that Hue's rulers did not hold the highlanders in the highest esteem, maintaining a pejorative attitude toward those 'primitive' mountain dwellers. The Muong and the Thô (Tày), because they had, with time, become culturally closer to the Kinh, were considered superior to other highland groups. With the latter, "it generally was believed that familiarity held the danger of polluting superior Vietnamese ways"17 and inter-marriage with state functionaries or employees, for instance, was stated in the 15th century Lê code as punishable.

It could be said that Imperial Vietnamese, and the French colonial regime that succeeded it, shared at first a common political understanding of the highlands in the north. To summarise that conception in a single word, it was that of a frontier. A geographical one obviously, due to the mountainous topography, it was also a geostrategic frontier, a buffer zone between different lowland states or, in the case of Yunnan, upland Warlords and non-Han monarchs with enough power nevertheless to pose a potential security threat to Tonkin. ${ }^{18}$ In addition, it was a cultural frontier, with upland populations being linguistically, genetically and ethnically distinct from the lowland Viet majority, while at the same time forming neither a unified cultural and political entity nor a confederation of independent elements. It is not an exaggeration to state that the northern uplands also represented, from the lowlanders' point of view, a distinct religious entity and an unchartered mythical

${ }^{15}$ McAleavy, Henry. Black Flags in Vietnam. The Story of a Chinese Intervention. London: George Allen and Unwin Ltd., 1968, 5,107.

${ }_{16}$ Essentially providing them with salt and metals bartered for forest products and, after the mid-nineteenth century, raw or boiled opium.

${ }_{17}$ Hickey, Gerald C. Sons of the Mountains. Ethnohistory of the Vietnamese Central Highlands to 1954. New Haven and London: Yale University Press, 1982a, 154.

${ }_{18}$ Winichakul, Thongchai. Siam Mapped. A History of the Geo-body of a Nation. Chiang Mai: Silkworm Books, 1994. 
territory with specific ghosts, spirits and malicious evils. Typically, mountain people were categorised as a bizarre mixture of humanity bearing uneasy characteristics: unruly, dangerous, in touch with the otherworld, practising barbaric rituals, a lesser kind of humans. This harsh appreciation of the montagnards mirrored a widespread human tendency found by countless ethnographic studies around the world, one that makes Us civilised and the Other barbaric, and this rule did not fail to apply in the Southeast Asian massif. The highlands there were thus not a space to be dealt with lightly, and colonising them was not seen as a necessary step; it was rather one to be avoided as long as feasible, preferably indefinitely.

\section{Under Frengh Rule}

Despite the initial similarity in the conception of the highland zones, when the French colonial apparatus actively started taking over Vietnam in the mid-19th century, a significantly different approach to the uplands was implemented. Not that the French were less biased towards highland populations; in Europe itself the persistent division between the 'civilised' plains and the 'uncivilised' uplands - and of course the fores $\mathrm{t}^{19}$ - was an ancient and persistent defining feature. However, following the Enlightenment, the naturalistic vision of human diversity had implanted in French thinking a durable vision of cultural relativism and, later, social evolutionism. ${ }^{20}$ The ideological foundations were then well in place to take French colonial perceptions of the highlands away from that of old imperial Vietnam.

In terms of geopolitics, France's will to impose direct rule over Vietnam entailed the implementation of Western notions such as the Nation-state and territorial sovereignty. The first obvious step in this political control of the new colony ${ }^{21}$ was the need to occupy the territory and subject its populations, and then set clear and solid borders of the national territory. Negotiations and a short war with China led in 1885 to bilateral agreements on an international border between

\footnotetext{
${ }^{19}$ Cf. a stimulating essay by Harrison, Robert P. Forests: The Shadow of Civilisation. Chicago: University of Chicago Press, 1992.

${ }^{20}$ Incidentally, the publication of Darwin's On the Origin of Species in 1859 is contemporaneous with the French takeover of central Vietnam.

${ }^{21}$ For convenience, I use the term colony generically here; Tonkin in the late 19th century was actually a Protectorate.
} 
French controlled Tonkin and south China. ${ }^{22}$ To the West, Auguste Pavie's diplomacy eventually led to the recognition of French preeminence over the Lao territory east of the Mekong river, while the ancient Tonkin-Laos border in the mountainous area west of the Black River was formalised. ${ }^{23}$ The highlands conquered, and their political limits set, all that was left to do was to firmly attach the populations to the colonial state.

The northern uplands, a harsh, barely accessible maze of mountain ranges and high valleys populated by alien minorities, did not offer promising enough economic or political potentialities to justify a colonial presence on a magnitude exceeding the simple safeguarding of the heartland, the Red River Delta. Accordingly, the French authorities preferred to keep a minimal number of troops in the highlands, just sufficient to guard the borders. Any increase in this minimal involvement was met with blunt rejection from the successive Governor Generals of the time. Infrastructure to access the region was also kept to a minimum, and was calibrated to support the military installations in the north. During at least the first decades of colonial French Tonkin - the period covered in this book - entrepreneurs and missionaries wanting to penetrate the highlands were to do so mainly at their own expense and risks, with minimal logistical support from the colonial administration except when accompanying the troops.

During the whole of the colonial period, French policy towards the northern highlands and its populations did not deviate significantly from this initial stance. Alliances with more or less significant highland potentates, such as the White Thái of the Sip Song Chau Tai, would suffice to ensure political control and economic exploitation of the desirable resources. Actual administration was confided to the military. This pragmatic approach was coherent with the cultural distinction that the French more or less openly admitted that they saw between the civilised European colonists, the somewhat civilised Annamite (Vietnamese) culture, the barely civilised Tai-speaking feudal groups in the mid-region, and the truly 'savage' tribal groups perched in the highlands. A symptom

\footnotetext{
${ }^{22}$ Fourniau, Charles. "La frontière sino-vietnamienne et le face à face franco-chinois à l'époque de la conquête du Tonkin." In Les frontières du Vietnam/Histoire des frontières de la péninsule indochinoise, ed. Lafont, P.B., Paris: L'Harmattan, pp. 85-103, 1989.

${ }_{23}$ Gay, Bernard. "La frontière vietnamo-lao de 1893 à nos jours." In Les frontières du Vietnam/Histoire des frontières de la péninsule indochinoise, ed. Lafont, P.B., Paris: L'Harmattan, pp. 204-232, 1989.
} 
of this cultural hierarchy in the French psyche is reflected in the proportionate number of articles devoted to each of these categories by French scholars which were published over 50 years in the prestigious Bulletin de l'École française d'Extrême-Orient. Official terminology also bore this distinction, geographically dividing Tonkin between the Delta, the mid-region (la moyenne région), and the high-region (la haute région). Administratively speaking, the provinces in the Delta fell under the direct administration of the civilian colonial state, while a large portion of the mid-region and all of the high-region were put in 1891 under military administration - the Territoires Militaires.

In this book it is the high-region that is the main focus of interest. In the French understanding, that region comprised nearly all the Tonkinese territories immediately adjacent to Laos and the Chinese border. Although under military administration, the coastal areas in contact with Guangxi in the extreme east of Tonkin were not part of it, and as such, it was the combination of highlands and border area that actually defined the high region. Thus, it can be said that the high region comprised all land above 500 metres, along a half-circle that had the Red River delta at its centre, and stretching from the province of Lang Sơn to the east, to Sơn La in the west. Today, these would correspond to the provinces of Lạng Sơn, Cao Bằng, Hà Giang, Lào Cai, Lai Châu, Điện Biên, and Sơn La, with adjacent portions of Yên Bái, Tuyên Quang, and Bắc Kạn. The river valleys cutting through this vast periphery of mountains were the main access roads, while a circular road, the Colonial Road no. 4 was swiftly built along the Monkay - Langson - Cao Bang axis to safeguard the most active section of the Chinese border.

\section{Peoples of Upland Tonkin Towards the End OF THE 19Th Century}

During the early years of the colonisation of Indochina, it was first through second hand accounts by Vietnamese informants and the reports of a handful of European observers that the existence of montagnard groups in the Southeast Asian massif began to be known to the French. Spearheading the colonial penetration of northern Vietnam, occasional explorers like Francis Garnier and Ernest Doudart de Lagrée in the 1860s, and Jean Dupuis and Émile Rocher in the 1870s, rowing their way up into Yunnan via the Mekong and the Red River, reported 
sightings of unknown peoples who they generally depicted as primitive, colourful enough to be portrayed, but without much commercial interest. ${ }^{24} \mathrm{~A}$ clear sign of this lack of knowledge was the general map produced by Garnier that accompanied the publication on his expedition of 1866-68. This map, titled Carte générale de l'Indo-Chine (General Map of Indo-China) showed the highlands in the north and west of Tonkin bearing the labels 'région inexplorée' and 'région à peu près inconnue' - yet to be explored and virtually unknown regions. ${ }^{25} \mathrm{~A}$ further illustration is provided by another map authored by the Société des Missions Étrangères de Paris and published with accounts of early attempts to make contact with potential converts in the mountainous north. This map shows the little known high region of western Tonkin bearing the mention tribus sauvages, savage tribes, without further specification. ${ }^{26}$

For the specific purpose of this book and to reduce to a minimum unnecessary complications, the ethnic diversity of the northern region, which amounts today to more than thirty different ethnic groups and sub-groups according to some authors, ${ }^{27}$ has been standardized along the broad ethnic categories that are most often found in the French colonial literature. ${ }^{28}$ It seemed more sensible to bear with the unavoidable imprecision and colonial overtones of some of these exonyms that characterized the writings of the turn of the 20th century. Therefore in the following chapters we will work with the categories most often found in the official French ethnonyms and ethnolinguistic taxonomy,

${ }^{24}$ See the colour sketches from the Garnier \& Doudart de Lagrée expedition to Yunnan in Garnier, Francis. Album pittoresque, frrst part of Atlas du voyage d'exploration en Indo-Chine. Paris: Librairie Hachette, 1873a.

${ }^{25}$ Garnier, Francis. Voyage d'exploration en Indo-Chine. Tome II. Paris: Librairie Hachette, $1873 \mathrm{~b}$

${ }^{26}$ Map 14: 'Mission du Tong-King occidental' dated 1889, in Launay, Adrien. Atlas des missions de la Société des Missions Étrangères de Paris. Lille: Desclée, de Brouwer et Cie, 1890.

${ }^{27}$ Khong Dien. Population and Ethno-demography in Vietnam. Chiang Mai: Silkworm Books, 2002.

${ }^{28}$ For a more complete ethnographic panorama of the northern highlands seen from non-Vietnamese viewpoints, see Lunet de Lajonquière Ethnographie du Tonkin septentrional. Paris: Ernest Leroux, 1906; Abadie, Maurice. Les races du Haut Tonkin de Phong Tho à Lang-Son. Paris: Société d'éditions géographiques, maritimes et coloniales, 1924; Lebar, F.M., G.H. Hickey and J.K. Musgrave (eds). Ethnic Groups of Mainland Southeast Asia. New Haven: Yale University Press, Human Relations Area Files, 1964; chapters 1 and 18 to 20 in Kunstadter, Peter (ed.). Southeast Asian Tribes, Minorities and Nations. Princeton: Princeton University Press, 1967; and Schrock, Joann L. et al. Minority Groups in North Vietnam. Ethnographic Study Series. Washington D.C.: Headquarters of the Department of the Army, 1972. 
and hence, in the missionary writings of the time. Today's official Vietnamese classifications will be presented in the next section so as to give the reader an appreciation of who these people are in the present, but it should be kept in mind that these groups are not consistent with colonial categories. Just to underline the taxonomic complexity in the uplands, here is a sampling of issues at stake. Colonial authors tended to confuse the Nùng, an important Tai-speaking group on the Guangxi border, with the 'Thô', their more numerous cousins and neighbours. But the ethnonym Thô was later allocated instead to a small Vietspeaking group dwelling in the Annamitic Range while the colonial 'Thô' were given back their rightful autonym, the Tày. Farther west, most of the time the Red Thái and the Tai Lue on the Laos-China border were mixed up with the more numerous Black and White Thái, their close relatives in Tonkin; concurrently, some Tibeto-Burman speaking groups such as the Lolo were wrongly classified into the Tai-speaking family. Nearer to Hanoi, the Muong, close relatives to the Viet, were often registered as Tai speakers while they actually belong to the VietMuong linguistic branch. Such confusion of specific identities cannot easily be solved. To try to decide, retroactively, to which categories the peoples colonial authors were mentioning should belong to in today's ethnolinguistic categories would be a hazardous enterprise, with shaky scientific grounding and a good risk of error.

Bearing in mind the taxonomic predicament, today we nevertheless have a fairly reliable picture of where the main ethnic groups of highland Tonkin were located at the time of the arrival of the French in the 1880s. The Carte Ethnolinguistique published in 1949 by Service géographique de l'Indochine under the supervision of École française d'Extrême-Orient (EFEO ${ }^{29}$ summarizes this information in broad terms. Although this map is posterior to the French conquest of Tonkin by a good sixty years, its state of sophistication and its incorporation of the best available linguistic findings of the time, combined with the maximum extension of the French exploration of the Indochinese territory, make it the most detailed and overall accurate visual representation of the distribution of ethnic groups in all of French Indochina. The ethno-linguistic categories it uses were proposed and debated by the scholars of the time, and formed thereafter the basis for colonial ethnic classification of the Indochina population. As far as Tonkin was

${ }^{29}$ Service géographique de l'Indochine. Carte ethnolinguistique (au 1:2,000,000 ème). Under the supervision of EFEO. Hanoi: Service géographique de l'Indochine, 1949. 
concerned, these linguistic categories amounted to nine: Vietnamien, Muong, Thai Laotien, Thai, Nung, Sino-Tibétain, Môn Khmer, Man, and Méo. This French colonial categorisation, when completed with the specific ethnonyms indicated on the map, shows a logic that allows one to target with reasonable accuracy the sub-categories and to connect them in broad terms with today's linguistic classifications. I will therefore use this French colonial linguistic categorization as the main structure to list and present the ethnic diversity present in upland Tonkin at the time of the arrival of French missionaries.

\section{Vietnamien}

The French had long favoured the name Annamites, from Annam, to label the lowland majority called Viet or Kinh today. But when it came to naming the linguistic family, the French equivalent to Vietnamese, Vietnamien, was preferred. Today, the Vietnamese language is associated with the parent language Muong in the cluster Viet-Muong, a sub-branch of the Austro-Asiatic family. On the 1949 EFEO Map, the location of the Vietnamese speakers chiefly overlapped with all land situated at altitudes lower than 200 metres.

\section{Muong}

As just mentioned, the Muong belong to the Viet-Muong sub-division of the Austro-Asiatic family. On the EFEO map, all Muong speakers were located in the western foothills of the delta, in and around today's Hoa Binh province.

\section{Thai laotien}

This small category belongs to the Tai branch of the Tai-Kadai linguistic group. Linguistically, these Thai Lao are directly related to the Lao speakers of Laos. The EFEO map suggests that the river valleys tributaries of the Mekong, in particular the higher reaches of the valley of the Nam Ou, might have led some Thai Lao to install settlements in Tonkin, although none appears on the 1949 map.

Thai (Thô [Tày]; Black, White, and Red Thái; Thái Neua, Thái Lue, Thái Phong, Phouthai, Nyang)

The major portion of the Tai-Kadai family represented in Vietnam, this group moved to Mainland Southeast Asia from China between one and two thousand years ago (perhaps more in the case of the Tày). 
Spreading today over northern Vietnam, Laos, Thailand, northern Burma and southwest China, Tai-speakers have, thanks to their relative isolation from each other, developed over time an array of related languages that eventually gave birth to different ethnic groups and ethnonyms. In Tonkin and eastern Laos, the EFEO map registers 9 Thai groups, most straddling that border. This is the case for the Thai blancs, the Thai noirs, Thai rouges and Thai neua, all of whom are found both in western Tonkin, that is west of the Red River in the Black River and Song Ma watersheds, and east of the Mekong river in Laos. The Thái Lue are shown to dwell along the Chinese border (Yunnan). East of the Red River are the 'Thô' [Tày] who occupy a half-circle around the lowlands of the Delta all the way to the coast along the border with China (the Chinese provinces the French called the two Kouang: Kouangsi and Kouangtong). Upriver from them are pockets of less numerous Nyang spread along the Yunnan border between the Red River and the upper Clear River.

\section{Nung}

An unnecessary category much like the Thai laotien, the Nung (today the Nùng) should be grouped with the other Tai speakers listed as Thai. They constitute part of the eastern branch of that family along with their cousins in Guangxi, the Zhuang, the most numerous Minority Nationality in China. On the EFEO map, all the Nung are located east of the Red River along the Chinese border, with a concentration in the provinces of Langson and Cao Bang.

All these Tai-speaking groups (Thai laotiens, Thai, and Nung) had in common the fact that they dwelt at intermediate altitudes between the plains and the mountains. They occupied the moyenne région favouring the lower slopes of river valleys and plateaus between 200 and 800 metres. In terms of political organisation, the Tai groups represented a transitional stage between kinship-based systems of the uplands, and fully-blown feudal organisation in the lowlands, with an aristocracy ruling over peasant masses. In certain areas like the Black River, the Tai-speaking villages and towns were inter-connected through a feudallike, loose agrarian political regime composed of relatively independent principalities under the suzerainty of a Tai lord. ${ }^{30}$ Whatever the precise state of their political formalisation, the Tai were in tributary relation-

${ }^{30}$ Condominas, Georges. "Essai sur l'évolution des systèmes politiques Thais." Ethnos, vol. 41, pp. 7-67, 1976. 
ships with their more powerful neighbours: imperial Vietnam most of the time, but also the Lao kingdom of Luang Phrabang, and powers as remote as Burma and China.

These Tai-speaking groups all formed peasant economies based on subsistence-oriented horticulture, wet rice cultivation, and trade. The bulk of this trade concentrated on regional marketplaces attended chiefly by other Tai speakers, where cash crops such as rice and animal produce like eggs and meat would be exchanged. Due to their location at the periphery of the Red River delta, the Tai groups were also in a favourable position to act as intermediaries between the Viet and other traders coming from afar, such as other minorities higher in the mountains, or long haul traders from Yunnan and Guangxi. The Tai speakers controlled the river valleys leading into the hinterland and they saw fit to take advantage of this in terms of taxation and control over the flow of goods.

At the time of French installation, Animism was important among the Tai, with influences from Chinese belief systems such as Taoism and ancestor worship. The Kinh had implanted in the nearest Tai groups a mixed aristocracy involving Kinh mandarins who had married locally and whose descendants acted as power brokers in the mid-region. The Kinh used these elites as go-betweens to plant the seed of acculturation in the Tai groups, although the ultimate goal was political and economic subjugation, not cultural merging.

\section{Sino-Tibétain}

This is another composite group although far less numerous than the Tai-speaking group. It is called today the Sino-Tibetan language family. In colonial times, in northern Vietnam it included a number of sub-groups: the Chinese and Tibeto-Burman sub-families, the latter including the Lolo-Burmese groups. The EFEO map locates pockets of Sino-Tibetan speakers at the extreme north-west and extreme east of Tonkin, the former including the Houni [Hani], and the Ho [Haw, Hoa, Hui], and the latter, the Kho, essentially lowland Han speakers around Moncay.

\section{Môn Khmer}

The only group listed on the EFEO map as dwelling in Tonkin and belonging to the Mon-Khmer sub-category of the Austro-Asiatic family are the Mou (today the Khmu). They dwelt in their larger numbers in Laos while very small extensions penetrated into extreme western Tonkin. 
Man

Belonging to the Miao-Yao branch of the Austro-Tai linguistic family, the Man (a Chinese exonym) are known internationally as the Yao today, although it may be more accurate to name the ones dwelling in northern Vietnam Kim Mien, their autonym. They form one of the most recent migrant groups to have entered Tonkin from China.

Méo

This name was derived from the Chinese exonym Miao and was used to refer to the other, more numerous branch of the Miao-Yao family. The particular branch of the large Miao group in China-nearly ten million in total - that can be found in Vietnam today is the Hmong.

The EFEO map locates the Sino-Tibetan Man and Méo at higher altitudes than the Tai groups, up to 2000 metres. Their habitat was therefore limited to the higher northern reaches of the main river valleys and to the summit areas in the upper-region, the haute région. They are often shown as being embedded within the areas controlled by the Tai speakers.

At the time of the French takeover, all the non-Tai and non VietMuong speakers dwelling in Tonkin were practising either nomadic swiddening or a combination of swidden and sedentary agriculture. All had their economic systems based on subsistence agriculture complemented by limited trade aimed at acquiring the indispensable items that could not be produced in the mountains, such as salt, iron, silver, or gun powder. Their trading partners included other minorities in upper Tonkin, but it is undoubtedly with the adjacent Tai-speaking groups in the mid-region that trade flourished. With lowland Viet being the ultimate buyers of forest produce, coffin-wood and opium, the Tai-speakers were in a strategic location to impose their role as intermediaries between the highland embedded minorities and the lowland majority.

In terms of political organisation, the non-Tai and non-Viet-Muong groups had a kinship-based structure with no political formalisation beyond the kinship group or, on occasions, the village. None of these groups had yet been reached and/or successfully converted to one of the main religious traditions that had taken root in the Peninsula. They were Animists, although syncretisms with Chinese philosophical systems were frequent, especially among the later migrants from China like the Hmong and the Yao. 


\section{The Situation Today}

For several decades after the French departed from Tonkin in 1954, no Western anthropologists, linguists, or historians, at least no nonCommunist ones, could study highland minorities dwelling in the mountain ranges circling the Red River delta. When the official decision was made in 1986 by the Communist Party to open up the country to the market economy - a liberalisation process known there as Đổi Mớ $i$, the 'economic renovation'-Vietnam gradually welcomed again foreign scholars from all political allegiances. Very slowly at first, then at an accelerated pace thanks to a relaxation in the early 1990s of the controls over the circulation of foreigners outside the main cities, huge areas previously inaccessible to non-authorised researchers became the focus of new research. Today, in the country's northern highlands, in addition to Vietnamese ethnologists working for the State, dozens of local and foreign researchers as well as research students are climbing the hills to study some of the five million or so non-Kinh highlanders living there.

Vietnam recognizes five indigenous linguistic families within its borders, each comprising several minority groups. These are: the $\mathcal{N a m}-\dot{A}$ family (Austro-Asiatic), with the Việt-Muoòng (4 groups including the Kinh) and Môn Kho'-me (Mon-Khmer, 21 groups) branches; the Nam-Đảo family (Austronesian or Malayo-Polynesian, 5 groups); the Thai-Kadai family (Tai-Kadai, 12 groups); the Sino-Tibetan family, with the Sinitic (3 groups) and the Tibetan-Burman (6 groups) branches; and finally the Hmông-Dao family (Miao-Yao, 3 groups). ${ }^{31}$ Of the 54 'nationalities' (các dân tộc) officially catalogued in the country, 53 are considered 'national minorities' (các dân tộc thiểu số). The 54th group, the Kinh, forms the national ethnic majority with a population of 65,795,718 in 1999 .

At the 1999 census, the 53 official national minorities of Vietnam represent 10,527,455 individuals, or 13.8 per cent of the national population. However, as four of these are simply overspills from lowland majorities in neighboring countries, they should be subtracted from this total. These are the Hoa (Chinese), Kho-me (Khmer), Cham, and Lao, who together record a total population in Vietnam of 2,062,029. Thus the total of highland minority representatives in Vietnam, sometimes

${ }^{31}$ Đặng Nghiêm Vạn, Chu Thái Sơn, Lưu Hùng. Ethnic Minorities in Vietnam. Hanoi: Thế Giới, 2000, 2. 
called các dân tộc miền núi or ngươi miền núi (the mountain people nationalities) becomes 8,465,426, or 11.1 per cent of Vietnam's population. Roughly two-thirds of these are found in the northern highlands. ${ }^{32}$

Of these 49 highland groups, the six largest numerically in 1999 were the Tày $(1,477,514)$, the Thái $(1,328,725)$, the Mường $(1,137,515)$, the Nùng $(856,412)$, the Hmông $(787,604)$, and the Dao $(620,538)$, all dwelling in the northern highlands. Together, these six groups form exactly 70 per cent of all highland minority populations in the country. The largest linguistic family represented in the north as well as in the rest of the country is the Thai-Kadai (Tày, Thái, Nùng, Sán Chay, Giáy, Lự, Bố Y, La Chí, Gờ Lao, La Ha, Pu Péo, plus the Lao) with 46 per cent of all national highland minority speakers, the Hmông-Dao coming second at 16.7 per cent. The provinces with the largest highland minority population are, in the north, Sơn $\mathrm{La}(728,431)$, Lạng Sơn $(587,718)$, Thanh Hóa (568,996), Hòa Bình $(546,861)$, Hà Giang $(529,551)$, Lai Châu (488,488), Cao Bằng $(467,379)$, and Lào Cai $(397,475)$. In the south, these provinces are Dắc Lắc $(524,541)$, Gia Lai $(421,902)$, Lâm Đồng (212,629), and Kon Tum (168,535). ${ }^{33}$

Over the last twenty years the economic renovation has contributed to somewhat reducing the intensity of Communist state authoritarianism in the highlands. A generally more liberal attitude regarding trade, religion, education, and cultural expression has, however, failed to completely dissolve the government's worries regarding highland security issues such as Christian agitation both in the north and the south, allegedly encouraged by outside agents. Yet, perhaps the most hotly debated issue regarding the highlands is environmental protection. The highland people of Vietnam are blamed by their government for the deforestation occurring in the uplands. In fact, the massive migration of Kinh from the plains, officially launched under the New Economic Zones scheme, put immense additional pressure on the natural resources of the upland ecosystems. Further, more or less spontaneous economic immigration unfolded at the end of the 1980s, and was soon encouraged, in the Gentral Highlands in particular, by crop substitution schemes and

\footnotetext{
${ }^{32}$ Michaud, Jean. Historical Dictionary of the Peoples of the Southeast Asian Massif. Lanham: Scarecrow Press, 2006.

${ }^{33}$ National Census of Vietnam, 1999, CD-ROM version. Since, Lai Châu has been divided into two distinct provinces. To harmonise with archival use and avoid unnecessary confusion, place names will generally be written in the rest of this book in conformity with what is found in the French colonial documents.
} 
extensive plantations such as coffee aimed at enticing ever more farmers. This policy persists today, compounded with economic migration of minority peoples from the north to the south, in particular the Tày, Nùng, and Hmông. This excessive stress on resources has caused social tensions and triggered severe social unrest as well as a deterioration of the environment, most dramatically visible in the rapid deforestation, the lowering of ground water tables, and the increasing severity of annual flooding in the lowlands. In search of a sustainable solution, Vietnamese scholars are conducting research on issues such as customary law in relation to natural resource management, on indigenous knowledge and indigenous strategies for improved fallow management, and on community-based forest management institutions.

The renewed academic interest for the highland societies of upland Vietnam faces many challenges. One of the most discouraging ones is the scarcity of written material to work with when attempting to trace back the history of these societies or in assessing their past state when evaluating the pace and importance of social change occurring today. Undeniably, ethnological research has been conducted by Communist ethnologists during the 1954-1980s years. But as Evans sharply pointed out, this production was heavily tainted by a very pragmatic ideology inherited from the USSR and China, which perceived minority nationalities as a 'problem' standing in the way of the Socialist project, of national unity, and of modernisation. Still, the rare Western anthropologists allowed to keep in touch with Vietnamese ethnologists before the economic renovation, showed in their own publications that local ethnographies, with their imperfections, nevertheless constituted a unique body of valuable on-site observations, one that awaits translation into English.

In this context of a lack of availability or plain scarcity of ethnographical material on Vietnam's highlanders, the French speaking cohort of anthropologists are at an advantage. During the nearly one hundred years that France was in a position to impact decisively on the course of Vietnam's history (1858-1954), an impressive sum of documents was released. Perhaps it is concerning the minorities in the Central Highlands that the largest amount of written material has been produced, this advantage due to a relatively late blitz of ethnographical research done between 1954 and 1975 when Western ethnographers formerly working in the north had retreated south of the 17th parallel. This was clearly a troubled period when, for strategic reasons related to the West's involvement in supporting the southern Republic of Vietnam's 
resistance against the northern Communist forces, large sums of money and logistical facilities were made available to perform anthropological research among the southern highland minorities. ${ }^{34}$

However, before 1954, it is arguably the uplands of the north that benefited most from the ethnographical research effort of colonial times. When the French unleashed their troops to take-over CochinChina in the south of Imperial Vietnam in 1858, it was towards the north that their main concerns regarding border security were directed. The historical feud between Imperial China and Vietnam had long conferred a geo-strategic importance to the Marches north and east of the Red River delta, an importance surpassing that of the southern highland frontiers where former foes (the Cham, the Khmer, the Lao, and the Siamese) did not pose a serious threat. Thus, in the north, massive military ethnographical ventures were organised by the French in 1898 and 1903 on a scale that was never matched in the south, to study populations dwelling beyond the Red River delta. Missionaries, administrators and academics then did the rest.

Today, the paradox is that this ethnographical data from the north is left largely untouched, even ignored in the performance of anthropological research on populations in the upland north of Vietnam. Untouched, first, by the Vietnamese researchers for whom the knowledge of French language has been downgraded to a low priority. Untouched also by the international community of researchers in anthropology for whom mastering Vietnamese already constitutes a tall order, while accessing French colonial archives becomes an obstacle often considered hardly worth the effort. Even French archivists and researchers are not entirely aware of the data contained in these archives.

As a result, a number of scholars who conduct their research on highland societies in the north of Vietnam today can unknowingly go down paths that have already been explored by their colonial predecessors. If they could take into account the history embedded in ancient publications and archives, many of the hypotheses researchers base their investigations on could be better demonstrated, perhaps wholly verified, or simply contradicted. Obviously this predicament is very complex and cannot be easily resolved. As alluded to in Chapter 1, this book thus

${ }^{34}$ Cf. Hickey, Gerald C. Sons of the Mountains; Hickey, Gerald C. Free in the Forest. Ethnohistory of the Vietnamese Central Highlands, 1954-1976. New Haven and London: Yale University Press, 1982b; and Salemink The Ethnography of Vietnam's Central Highlanders. 
becomes a contribution to helping researchers avoid such unnecessary repetitions and omissions by presenting in a concise form the most valuable among an important segment of those early ethnographical works performed during colonial times by some of its most ancient representatives, the Catholic missionaries. It also constitutes a glimpse into Western ethnology in the making. 
Jean Michaud - 978-90-47-42021-7

Downloaded from Brill.com๑4/26/2023 $\odot 9: 56: 23 \mathrm{AM}$

via free access 
PART TWO

COLONIAL ETHNOGRAPHY AND

THE FRENCH HERITAGE 
Jean Michaud - 978-90-47-42021-7

Downloaded from Brill.com๑4/26/2023 $\odot 9: 56: 23 \mathrm{AM}$

via free access 


\section{CHAPTER THREE}

\section{FRENCH ETHNOGRAPHY IN NEW FRANCE}

Taking the focus away from Asia for a moment, I want to introduce here one key period in the progress of French ethnographic tradition, that is, its North American colonial episode which spanned from the early 16th century to 1763 when France surrendered that colony to the British Crown. This detour is a bold move meant to step back in time, instead of laterally elsewhere in the late-19th century world, in search of the seminal production, a blueprint so to speak, of ethnographical knowledge and practice by French missionaries sent to missionize in the colonies. These two centuries of France's presence in North America were cause for many Catholic priests to find themselves, for the first time in France's history, embedded within diverse and utterly unfamiliar native cultures. This durable exposition has led to some of these men composing major pieces of observation of an ethnological nature, a good many of which today are considered classics of early anthropology. What I propose is to examine a few of these authors and their texts with an aim to verify the degree of refinement of French missionary ethnographic practice at the time, therefore setting a benchmark of that type of practice in French missionary ethnographic tradition.

This snapshot, as it were, is meant to serve as a point of reference in our later discussion of missionary ethnography in Southeast Asia, a strategy by which the value of late-19th and early-20th century ethnography produced by Catholic envoys in another colonial setting can be appraised. The logical limitations of such a distant comparison are obvious and need not be stressed here. Its validity, in my mind, lies in the signature heritage left by missionaries in Canada; an extremely well documented one that, for that very reason, must have supplied information and guidelines to 19th century followers. Or did it?... But let us not anticipate.

\section{New France 1534-1763, A Seminal Field of Missionary Ethnographic Pragtice for France}

More than three centuries earlier than its installation in peninsular Southeast Asia, France's official expansion towards the New World made 
a decisive contribution to the genesis of a French ethnographical tradition. In France, the Enlightenment itself owes much to that heritage.

Several tentative French colonial settlements were attempted on the shores of the Americas over the 16th century. Together, they were given the names of Francisca - to honour king Francis 1st - or Nova Gallia. In northeastern America it became Nouvelle France, New France. While France's general interest in exploring the far side of the Atlantic was akin to that of its European neighbours, that is, the quest for a passage to China and its riches, the early French installation of permanent settlements in the Americas was driven first by religious imperatives. These installations answered the need to find a resettlement location for the ostracized French Protestants trailing in a vicious battle against the Catholics for overall domination in the French kingdom. Facing growing adversity, Gaspard de Coligny, a staunch Protestant and Amiral de France under Henri III, made sure there were enough such expeditions in the second half of 16th century to eventually guarantee safe havens to his brothers and sisters in faith, should fleeing the motherland become inevitable.

While stating that France's first push towards colonial installation in the Americas was driven by religious motives is broadly true, conversion of the savages encountered in America was not, at least initially, on the agenda. Conversion, which was paid lip service over the 16th century in contrast to the aggressively proselyte colonial policy of Spain and Portugal, never caused the addition of more than a handful of priests on the ships sailing to the New World over that century, most of whom stayed overseas only for a few months. At that stage, missions sponsored by the crown were still a vision of the future. If the early colonists wanted conversions and needed protection, they had to solicit it from one or several powerful patrons for whom the personal benefits of the venture would eventually exceed the costs of arms and personnel.

Despite the well-known fact that Basque and Breton fishermen had already been fishing cod, whales, and seals in the Gulf of the Saint Lawrence River for more than a century, hitting periodically the shore to dry their catch and extract oil, permanent settlements were only established later on those shores in Tadoussac (1600), Sainte-Croix Island (1604), and Québec (1608). From there, carrying out a profitable fur trade with the 'savages' became the next strategic objective, in addition to looking for local riches in minerals as well as - the old obsession - for a maritime passage to Asia.

While the French started radiating out from these settlements into the hinterland, successive monarchs still showed no interest in providing 
financial support from the Crown for such actions. From Francis I to Louis XIII, each was content with merely granting commercial privileges to noblemen willing to invest their own fortune into this business opportunity. This situation was to change significantly in 1663 when, meeting grave difficulties with some unwelcoming Native Americans and faced with the very real possibility of having to abandon Canada, the Crown finally stepped in to take direct control, and Canada was made a colony of France. Louis XIV, his chief minister Cardinal Mazarin, and his minister of colonies Jean-Baptiste Colbert formed a powerful combination. Keen to expand France's power overseas, they also saw to the birth of the new colony. Royal troops were sent to Canada to repel attacks from certain Iroquois groups and eventually force them into submission. This military presence, not always massive enough for the liking of the governors stationed in Québec, nevertheless sufficed to also keep the British in New England at bay. But a few decades later, this could not ultimately prevent the final eviction of the French from Canada following their defeat on the Plains of Abraham in September 1759, confirmed by the Versailles Treaty of 1763 .

Thus, with a permanent settlement from 1600 to the 1760s, New France provided a unique opportunity for the French to relate to the Native Americans, conduct observations among them, and gain a fine level of understanding of their numerous and rich cultures. Even before, as early as the voyages of Jacques Cartier between 1534 and 1542, observations on native customs were noted and published. But it was later, in particular with Samuel de Champlain, founder of Quebec and the original European explorer of the upper Saint-Lawrence basin, that an abundant documentation was developed on the tribes he met over his three decades of yearly visits to Canada. Champlain understood the crucial importance of allying with some Native Americans - the Hurons and Abenaki in particular - against other native tribes - chiefly the Iroquois federation - as well as against Dutch and British threats. He understood well that in order to gain the natives' trust, playing by the native rules was mandatory. Under his authority and that of successors such as Frontenac, important initiatives were conducted to gain ethnographic information on the Hurons, the Abenakis, the Montagnais and the Iroquois most notably.

Gathering intelligence about these populations was therefore a necessity in order to perform the three necessary strategic steps in the installation of a durable colony: knowing, controlling, and allying with the natives, in order to trade successfully and keep foes in check. Interpreters fluent in the vernacular tongues were needed, education of 
selected natives in the French language was promoted, and gathering crucial information on enemy parties were all conditions of survival for the colony. Two strategies were implemented by the authorities. The first was to mandate the religious communities to recruit young natives and instruct them in the French language and customs; this was done by taking advantage of the custom of being 'given' native children by tribal chiefs as a form of ritual exchange aiming at linking natives and Europeans. Most of the native males thus educated in French would eventually become scouts and translators for the French authorities. The second strategy required to send young and adventurous Frenchmen to establish themselves within native villages, often accompanying missionaries and acting as servants for them. After a few years away, these now fluent interpreters in languages and cultures could be used to set up and carry out strategic missions. But so far, the benefits in terms of ethnographic writing were meagre as there are most unfortunately very little traces left by these native scouts and French interpreters. None of them were required to be literate to perform their duties, let alone to be able to write an account of their journeys. As a consequence, very little has remained from these potential informants. ${ }^{1}$

Parrallel to this civilian deployment and interwoven with it, the missionary presence in New France started early. Noble pious patrons back in France made parts of their fortunes available to fund missionary travels to and establishments in Canada. The first such party to arrive was of the Catholic Récollet order (Franciscan Recollect) who disembarked a few years after the foundation of Québec. In the 1630s, the Jesuit replaced the Recollect with a directive to provide European settlers with spiritual guidance, while the local authorities also directed a number among them to reach the native tribes with whom the fur trade was conducted in the basin of the Saint Lawrence and north of the Great Lakes. Conversion of the 'savages' was the official objective.

1 There are exceptions to this rule of course, with written accounts by explorers such as Pierre Esprit Radisson (Voyages of Peter Esprit Radisson being on count of his travels and experiences among the North American Indians from 1652 to 1684. New York: Smith, 1943 [1885]) and Robert Cavelier de La Salle (Relation of the Discoveries and Voyages of Chevalier de le Salle from 1679 to 1681, the Official Narrative. Melville B. Anderson, translator. Chicago, IL: The Caxton Club, 1901). These accounts focused primarily on geographical and economic observations. What was written on the natives these observers met on their way was above all determined by strategy: numbers, identity of chiefs, location and importance of settlements, etc. Nevertheless, these provide a useful glimpse into the native cultures at that time. 
This also rather conveniently required the Catholic priests to settle in native villages for long periods, often years, and learn the local languages and customs in accordance with the near-Machiavelian precepts later summarised by Abbé de Raynal: "In studying the savages' language, in conforming to their behaviour, to their preferences, in trying all possible means to gain their trust, [missionaries] have gained absolute power over their souls."

A good illustration of how missionaries were used by the colonial authorities is provided in early explorations. Jesuit Jacques Marquette was a member of the first French expedition down the Wisconsin and Mississipi Rivers in 1673, a journey which resulted in his travel journal, made on behalf of the Crown, being made public that same year. Soon after, Recollect Louis Hennepin, also commissioned by the King, explored the upper Mississipi River and was taken prisoner for one year by the Sioux in 1679. From such a unique experience, he published in 1683 his Description de la Louisiane, nouvellement découverte au sud-ouest de la Nouvelle-France, par ordre du roi, avec la carte du pays, les moeurs et la manière de vivre des sauvages [Description of Louisiana, newly discovered southwest of New France, by order of the king, with a map of the country, mores and ways of life of the savages] and, in 1697, his aptly titled Nouvelle découverte d'un très grand pays situé dans l'Amérique, entre le Nouveau Mexique et la mer glaciale, avec cartes et figures, l'histoire naturelle et morale, et les avantages que l'on peut tirer par l'établissement des Colonies [New discovery of a very large country located in America, between New Mexico and the icy sea, with maps and drawings, natural and moral history, and the advantages to be gained in establishing colonies]. ${ }^{3}$ Hennepin's works spelled out a political agenda and provided strategic information; they were translated into several languages and re-printed dozens of times. Other examples include Father Ménard in Wisconsin, Father Allouez north of Lake Superior, and Father Membré who joined the La Salle expedition to claim ownership of Louisiana in 1682. Even fifty years later, Jesuit

\footnotetext{
${ }^{2}$ Raynal, Guillaume-Thomas, abbé de. Histoire philosophique et politique des établissements et du commerce des Européens dans les Deux Indes. Neufchâtel: Libraires associés, 10 volumes, 1783, vol. VII, p. 295.

${ }^{3}$ Hennepin, Louis. Description de la Louisiane, nouvellement découverte au sud-ouest de la Nouvelle-France par ordre du roi, avec la carte du pays, les moeurs et la manière de vivore des sauvages. Paris: Veuve Sébastien Hure, 1683. Hennepin, Louis. Nouvelle découverte d'un très grand pays situé dans l'Amérique, entre le Nouveau Mexique et la mer glaciale, avec cartes et figures, l'histoire naturelle et morale, et les avantages que l'on peut tirer par l'établissement des Colonies. Utrecht: G. Broedelet, 1697.
} 
François-Xavier de Charlevoix, with a background in philosophy and humanities, was commissioned to travel to North America and to report on what he saw. His Histoire et description générale de la Nouvelle-France (1744) includes a narration of his travels and experiences together with diverse accounts of the ways of life of the native peoples. ${ }^{4}$

In this way, in New France, Catholic missionaries were actively involved in the colonial venture as spearheads of the state in the hinterland and among native societies. Even during the most violent times of the long period over which the French settlers were fighting their chief native foe, the Iroquois (that is until 1701) 'Black Robes' were sent to live with the enemy as well as with the allies.

To get a sense of these French missionaries' vision of that 'savage' Other in New France, let us consider the work of a few of them, in particular one of the most celebrated figures among many who have written diaries, letters and chronicles, Jesuit missionary Jean de Brébeuf, whose life and work constitute in more ways than one a blueprint of French Catholic missionary work among natives in the colonies.

\section{Sagard, Lafitau, and Brébeuf}

In order to suitably approach Jean de Brébeuf's ethnographic legacy, setting the scene with two contrasting, yet complementary missionary authors is a worthy exercise. Recollect Gabriel Sagard and Jesuit Joseph-François Lafitau are today among the most widely cited names of Amerindian ethnography in French America. Sagard's main work was published in two volumes as Le Grand Voyage du Pays des Hurons Situé en l'Amérique vers la Mer Douce, les Derniers Confins de la Nouvelle France dite Canada [The Great Voyage to the Huron Country located in America Towards the Fresh Sea, the Last Marches of New France also called Canada $]^{5}$ that included a Huron language dictionary. In spite of being the fruit of only a brief stay in North America, his work quickly brought him fame in France and became a benchmark as well as compulsory

${ }^{4}$ Charlevoix, Pierre François-Xavier de. Histoire et description générale de la Nouvelle-France, avec le journal historique d'un voyage fait par ordre du roi dans l'Amérique septentrionale. Paris: Rolin Fils, 6 volumes, 1744. Incidently, it is Charlevoix who wrote the entry 'Sauvage' in Encyclopédie by Diderot and D'Alembert.

${ }^{5}$ Sagard-Theodat, Gabriel. Le Grand Voyage du Pays des Hurons Situé en l'Amérique vers la Mer Douce, les Derniers Confins de la Nouvelle France dite Canada avec un Dictionaire de la Lanque Huronne (1632). Paris: Librairie Tross, 2 volumes, 1865. 
reading for Sagard's successors evangelizing Canada. As for Lafitau, his most celebrated work, Møurs des Sauvages amériquains, comparées aux møurs des premiers temps [Customs of the American Indians Compared with the Customs of Primitive Times] was published in 1724 and inspired several Enlightenment thinkers in France. ${ }^{6}$

Gabriel Sagard-Theodat (c. 1600-1650), arrived in the hamlet of Quebec City in 1623. He soon went to settle for nine months in Huronia, the Huron country situated on the northeastern shore of the namesake lake, being, with his comrades Joseph Le Caron and Nicolas Viel, among the earliest French missionaries to be posted among these Native Americans. However, he hastily returned to France the next year when called back by his religious superiors. While in Huronia, Sagard, instructed to do so by his superiors, had spent most of his time recording the local customs and describing with precision their country's fauna and flora. For his missionary colleagues who would follow him in the field, and at the request of the civilian and religious authorities for whom such a tool was of importance, Sagard also learned enough of the Huron language to co-author a dictionary in 1632. This work was at the time, the most comprehensive research done on any native North American language. Even today, it remains the most complete compendium of early contact Huron language, all the more invaluable since that form of Huron language is no longer spoken today.

A self-taught ethnographer, Sagard made detailed descriptions of the culture of the Huron. A good example is his depiction of tobacco and smoking practices which not only included the production, transformation and smoking of tobacco together with the making, decorating, maintenance and usage of pipes, but also records of myths, legends and rituals associated with tobacco smoking. Both as a catholic missionary and a representative of the colonial state, Sagard personified and became an early model of the combination of vocational motivation and political work that defined missionary activity in French Canada. Back in France, Sagard presented a memoir to the Duke of Montmorency on the state of religious affairs in New France in which he vilified the fur trade companies and their agents among the natives, a culpable influence that he assessed counterweighted missionary actions. He convinced his superiors of the necessity to send a more powerful

${ }^{6}$ Lafitau, Moeurs des sauvages amériquains. 
religious congregation to tackle this difficult situation. Thanks in large part to his report, the choice of the powerful Jesuits as a reinforcement was ratified by Cardinal de Richelieu in 1625 .

Much has been said and written about the life and work of Jesuit missionary and writer Joseph-Francois Lafitau (1681-1746). Indeed, Arnold Van Gennep (1913), Alfred Métraux (1963), Michèle Duchet (1971), Michel de Certeau (1980) and Andreas Motsch (2001) among others have acknowledged him as a father of comparative anthropology. Lafitau went to New France on two occasions. Between 1712 and 1717, he was posted in the Iroquois mission of Sault Saint-Louis near Montréal where he conducted a thorough study of Iroquois culture. Back in France to take up duties with his congregation, he actively pleaded in favour of his American prozelites while working on the publication of his Mours des Sauvages amériquains. Returning to Canada in 1727, he became Superior of Sault Saint-Louis mission but soon had to abandon this posting to return to Paris for good in 1729 and take up more duties for his Society.

Lafitau's 1724 Moeurs is by any standard a stunning piece. Its author had received a very solid education. Despite the numerous weaknesses that are visible when scrutinized with today's eyes, the scientific scope of this book exceeds by far that of Sagard's. With a crucial century of European intellectual history unfolding between him and his 17 th century predecessor, Lafitau was more able to distance himself, to reflect on his object, and to include his personal deliberations in his writings - his political and epistemological project. ${ }^{7}$ Using first hand observations combined with a selection of notes made by earlier authors also active in the Americas (over 150 different sources are quoted approximately 400 times in the text, including travellers, explorers, philosophers, scientists, and missionaries), Lafitau wished to write, as the extended title of his Meurs shows, a vast comparison between the native American mores and those of European Antiquity. His project, evolutionist by nature, was in part designed to better comprehend the nature, the origin, and the evolution of human civilisations separated by space and time, and to uncover a pattern of progression towards civilization and Christ. He underlined the 'natural qualities of the savages' closer to Adam and Eve - innocence, kindness, simplicity, ignorance - and opposed these

${ }^{7}$ Motsch, Andreas. Lafitau et l'émergence du discours ethnographique. Québec and Paris: Septentrion and Presses de l'Université de Paris-Sorbonne, 2001, 26-40. 
to the decadence of the modern (European) Man. He was in this way positioning himself at the heart of the unfolding philosophical project of the Enlightenment. Today, along with Pierre de Charlevoix, Lafitau is widely regarded as the most remarkable historian and naturalist ever sent to Canada by the Jesuits. Møurs has sometimes been acclaimed as the first scientific treaty in this field.

But for the purpose of more finely measuring the ethnographic practices in New France resembling that of later missionaries in upper Tonkin, the most fitting of the three characters portrayed here is Jesuit Jean de Brébeuf (1593-1649). In producing their ethnographies and comparisons, Sagard and Lafitau willingly made their observations and thoughts available to a wide and educated audience, for political or academic purposes. Jean de Brébeuf instead quietly wrote for an in-house publication the Jesuit congregation in New France had set up to report to Paris and to let devout readers in France know about their work among the 'savages. ${ }^{\prime 2}$ The rest is history. The yearly consolidated Relations des Jésuites en Nouvelle-France, the Jesuit Relations in New France yielded 41 volumes between 1632 and $1672 .{ }^{9}$ These have been translated into English in 73 volumes, and are considered today the most significant source of information on Native Americans ever produced during the 17 th century. ${ }^{10}$

An amalgamated prose, the Relations formed an essentially collective work sent from the field. Often anonymous authors dutifully fed their mission Superior year in, year out, with the details of their daily joys and miseries in the course of an often solitary life in far away outposts. These missionaries were filled with the assurance that their writing would be reviewed by a colleague before being released, and

\footnotetext{
${ }^{8}$ Jesuit superiors had started sending Rome in 1565 a yearly report on their activities around the world. At first, these reports were for the exclusive use of the Society and the Pope. Later, the Jesuits decided to make these Relations public, which thus came to act as propaganda to attract donations and recruits. Local reports written in the field were first channelled to a distinguished and prudent member of the Society who could write well. He would compile these into a general report leaving a fair amount of space to individual authors who wrote the pieces in the first place. Thérien, Gilles. "Introduction." In Écrits en Huronie, Brébeuf, Jean de, Montréal: Bibliothèque québécoise, pp. i-lix, 1996, XXXVIII.

${ }_{9}$ To which must be added the unpublished Relations of 1672-1678.

${ }^{10}$ Cf. Thwaites, R.G. The Jesuit Relations and Allied Documents. Gleveland: Burrows Brothers Co., 73 volumes, 1896-1901. Pouliot, Léon. Etudes sur les Relations des jésuites de la Nouvelle-France (1632-1672). Paris: Desclée de Brouwer, 1940; Trigger, Bruce (ed.). Handbook of North American Indians. Vol. 15: Northeast. Washington: Smithsonian Institute, 1978.
} 
that beyond their colleagues, families, and friends, the pious sponsors and prospective recruits were likely to be the only readership. Untypically, however, due chiefly to a lack of available personnel in Québec to edit the reports coming from various missions across New France, the reports filed by the successive Superiors of the Huronia mission from 1635 to 1649 were passed directly to Paris without significant alteration, and the individual names of the Huronia Superiors who produced them remained explicitly attached to the texts. These were then made public by the Directors as distinct pieces of their worldwide Relations, this one reporting on Huronia alone. It is in this noninterventionist context that the two yearly reports written by Brébeuf as superior of Huronia, in 1635 and 1636, found their way into the final cut virtually untouched.

Ethnohistorian Bruce Trigger has eloquently exposed that in the first half of the 17th century, Huronia had first been visited in 1615-1616 by Recollect Joseph Le Caron and Samuel de Champlain, founder of Québec. With the growth of the fur trade, Sagard and colleagues Le Caron and Viel returned to settle a mission among the Huron in the mid 1620s accompanied by explorers and agents of the trade, including Pierre Boucher, François Gendron, Nicolas Perrot, and famously, Frenchmen turned native Étienne Brûlé and François Marguerie de la Haye. The name Huron was an exonym given by these first French visitors after the hair style of the natives, the Huron calling themselves Ouendat (Wendat), which became Wyandot in the USA. Huronia at the time of Brébeuf covered an area of approximately 1800 square kilometres. It was located between the Georgian Bay and Lake Simcoe in Ontario, approximately $125 \mathrm{~km}$ north of Toronto. Some have estimated the Huron population at the time at 30000 , some at 10000 . Others assessed that in the 1630s, within a few years, the population of Huronia dropped from 30000 to 12000 due to smallpox and other infectuous diseases unknowingly brought along by Europeans - including Brébeuf. The population was scattered over roughly 20 villages, some surrounded with wood palisades, and the population practised a combination of horticulture and hunting. The Huron, who had allied with the French since Champlain had helped them defeat an important Iroquois party in 1610 at the lake bearing his name, were in competition with the latter, themselves supported by the Dutch and the British from New England as intermediairies in the profitable fur trade. The French missionaries saw great conversion potential in the sedentarized Huron as opposed to the nomadic or semi-nomadic Abenaki, Algonkin, 
Cree, Ottawa, and others. The more so since Huron language was used as the lingua franca among different groups north of the Great Lakes. Mutual interest allowed for French agents to come to live among the natives in Huronia, and for Huron prozelytes to attend French religious schools in Québec, Trois-Rivières, and Montréal. ${ }^{11}$

In the 1640s, hostilities intensified between the Iroquois and the Huron. The early advantage the latter had built up thanks to French firearms acquired through the fur trade eroded away when the initially reluctant British and the Dutch finally agreed to provide the Iroquois with similar implements. From their main domain south and east of Lake Ontario, Iroquois parties grew bolder and more numerous in the Saint-Lawrence valley and north of Lake Ontario. With the unexpected help provided by European infections decimating the Hurons, the Iroquois destroyed Huronia in 1649-1650, killing large numbers among their enemies and pushing wary survivors further away; a fraction of Christianized Huron took refuge in the town of Québec, where their only remaining community in Canada still lives today.

Though one obviously has to remain cautious when attempting such distant comparison, we may notice that in terms of geopolitics, the Huronia of Brébeuf bore a number of similarities with the uplands of Tonkin later colonized by the French. Huronia was on the edge of the French domain and inhabited by little known native groups with whom alliances were sought. The trip from Québec to Huronia took three to four weeks through difficult terrain. Small military parties had been through it to pacify the region, but it was down to the missionaries to secure the native allies. The most pressing needs were gaining language proficiency, bringing French literacy to a native elite, and to make sure that commercial endeavours would be secured over a large territory. In terms of actual missionary activity, long immersion was seen as the best strategy, and ethnography became a tool for ensuring lasting obligations and control. The economic potential of the Huron and their trade networks were harnessed to bring to Quebec the riches of the forest - furs, essentially - much the same way as the French in Tonkin were eager to harness opium production in the mountains and channel it to the transformation industry in Hanoi and Saigon. Unlike Tonkin however, the Jesuits in Huronia could not really count

${ }^{11}$ Trigger, Bruce. The Children of Aataentsic: A History of the Huron People to 1660. Montréal: McGill-Queens University Press, 2 volumes, 1976. 
on military backup in case of problems with the natives, New France in the first half of the 17th century being practically devoid of military personnel. Wisely, missionaries on assignment there knew to remain extremely careful not to offend their hosts unnecessarily.

Jesuit Jean de Brébeuf, the man who interests us, was born in 1593 in a hamlet near Condé-sur-Vire in western Normandy. Like Sagard, who preceded him to the field only by a few years, Brébeuf came from the rural bourgeoisie. He studied at the seminary in Rouen and was ordained as a priest in a hurry in 1622 when his frail health led his superiors to believe that he might die soon. Having recovered, he was made college administrator in Rouen, a position requiring sound intellectual capacities. He became involved in a famous dispute between the Jesuit order and Rouen's Protestant leaders, which constituted an opportunity for Pierre Coton, Superior of the Society of Jesus, to take notice of him. Despite his frail health, Coton decided to send Brébeuf with a few Jesuit colleagues to assist the struggling Recollects in New France. Brébeuf arrived in Québec in 1625 and spent his first winter with a hunting nomadic Montagnais (Innu) band, learning their language. The following summer, he moved to Huronia with a handful of companions, missionaries and laymen to set up a new mission. Successfully deflecting accusations of evil doing by his hosts, who could not explain otherwise the sudden and dramatic death toll amongst them while the 'Black Robes' remained healthy, he maintained his presence there until the Kirke brothers captured Québec on behalf of England in the summer of 1629. French subjects being forced to return to the motherland, missionaries had to leave too. Brebeuf thus resumed his duties in the Rouen college until Canada was handed back to France at the 1632 Saint-Germain-en-Laye treaty. In March 1633, Brébeuf set sail for Québec on the same ship as Champlain and for his first year back in the recovering colony, stayed in the Québec City Jesuits' house and taught what he knew of the Huron language to his companionspresumably using Sagard's dictionary published the year before. He then returned to Huronia in 1634, this time in the capacity of Superior of that mission, which explains why he was asked to write the Relations for the years 1635 and 1636. In 1638, his colleague Jérôme Lalemant replaced him as Superior and Brébeuf could thereafter devote all his time to proselitizing among the Huron and the Neutrals. In 1642, he returned to Québec for two years largely to recover from an injury he had suffered the winter before. By 1644, he was back in Huronia and kept preaching the Huron until March 1649 when a village where he 
was working at the time was taken over by an Iroquois party. Most Huron villagers fled or were killed. Over the next two days, Brébeuf and his collegue Gabriel Lalemant (nephew of Jérôme) were tortured in the customary Iroquois way - a practice he was well acquainted with, having himself prayed with Iroquois prisoners being unhurriedly put to death by their Huron captors - and killed. His heart, recipient of the courage displayed during his supplice, was eaten by the Iroquois. A splendid end proving that he had been accepted within the mental universe of his captors, making Laburthe-Tolra say that "Jean de Brébeuf thus pushed 'participant observation' to its paroxysm." 12

In total, Brébeuf spent 15 years living among the Huron, with whom he became intimately acquainted. Over the three years of his first assignment, he hardly attempted any converting, focusing his energy instead on learning the vernacular language and understanding their world. $\mathrm{He}$ was adopted as a member of the Bear nation, the largest subgroup of the Huron confederation. Contemporanous observers, including natives, were astonished by his mastery of the Huron language.

In 1635 Brébeuf produced the first yearly report on the Huronia mission, which he wrote in a fairly unremarkable way, simply narrating the succession of events that happened to him, his colleagues, and his community over twelve months. The next year, in addition to narrating the year again, he also saw an opportunity to assemble his thoughts on his hosts' culture. ${ }^{13}$ Brébeuf's 1636 Relation, the most interesting one, was thus shaped in two unequal sections. The first one was approximately 16000 words divided in four chapters. Much as for the 1635 Relation, it narrated chronologically the joys and chores of a year amongst the Huron, in accordance with the expectations of the Society's superiors. Then, chapters 3 and 4 are of specific interest, the latter briefly discussing the particulars of the vernacular language, while the former warned prospective comrades wishing to join the mission of the many dangers and discomforts of such a demanding assignment. But with over 25000 words, roughly 85 pages, it is the second part of the 1636 Relation that formed the bulk of the text, divided into nine thematic

\footnotetext{
${ }^{12}$ Laburthe-Tolra, Philippe. "Pourquoi et comment un lien inextricable existe entre anthropologie et mission chrétienne." In Anthropologie et missiologie: XIX ${ }^{e}-X X^{e}$ siècles: entre connivence et rivalité, eds. Servais, Olivier \& Gérard van 't Spijker, Paris: Karthala, collection Mémoire d'Églises, pp. 15-24, 2004, 18.

${ }_{13}$ These 1635 and 1636 texts have been reprinted in: Brébeuf, Jean de, Écrits en Huronie, Montréal: Bibliothèque québécoise, 1996.
} 
chapters of roughly equal size. In writing these pages, Brébeuf wanted to "content all those curious to know about the mores and customs of those peoples." He also noted that when his usual daily activities as a priest were done, there was nothing else for him to do than learn the language, converse with the sauvages and amass information. Ordinary observation over several years indeed became the most important channel for him to gather data on such topics as feasting, dances and games (chapter 4) and death rituals (chapters 8 and 9). What he wrote in relation to Huron mythology (chapter 1), the otherworld (chapter 2), the interpretation of dreams (chapter 3), 'sorcery' (chapter 5), and political organisation and decision making process (chapters 6 and 7 ) most definitely necessitated a trusting relationship with his informants, a proof of the depth of his integration into Huron society.

This division into thematic chapters and the choice of themes most likely came to Brebeuf through suggestions from his superior Paul Le Jeune in Québec, who had written in the 1634 Relation a moralistic and rather ethnocentric account of the customs of the Montagnais, an Algonkian group situated lower along the Saint Lawrence valley. It also certainly came from reading similar works written by some of his colleagues elsewhere in the world, and most likely through reading the works of his predecessor in the same location, Gabriel Sagard. Brébeuf himself did not say a word on his methods.

As Gilles Thérien has summarized, several authors have noted that in Brebeuf's texts, as well as in those of his two successors at the helm of the Huronia mission, studying native religion was seen as a key to understanding the Huron psyche and finding the most effective channel through which the Bible's message could be passed on to them. ${ }^{14}$ This had been Brébeuf's deliberate priority in Part 2 of the 1636 Relation. Once this main concern was addressed, with nothing else being required from him, Huron domestic and social life also caught his attention, as well as the political structure of Huron society, including forms of individual power. Broader forms of policing were shown as being virtually non-existent, most legal decisions being reached by consensus. Brébeuf also competently described funeral rituals, and his accounts of "superstitions" and "magic" have brought to light two important features of Huron animism: dream interpretation, and ritual healing. Feasts and games were detailed but appear not to have been fully understood as

14 Thérien, "Introduction." 
cohesive social activities; nor were the ceremonial exchange of objects repeatedly passed on from one group to another (this was three centuries prior to Marcel Mauss' seminal deliberation on the ritual nature of the gift). ${ }^{15}$ Now and then finally, Brébeuf mentioned the mores of other peoples for the sake of a brief, heuristic comparison, for instance the Japanese and the Chinese, presumably based on earlier contributions he read in the Jesuit world Relations.

However, it is not just what was being addressed in Brébeuf's text that bears interest, but also what was not. Oversights and confusion often cropped up. Huron horticultural economy consisted of sending men on frequent hunting and fishing trips as well as war parties while women stayed closer to the villages. This was cause for the Jesuit's emphasis on the role of women in Huron society, sedentary activities taking precedence over nomadic ones in his descriptions. More predictably, information on rites of passage and sexual life in general, which probably embarassed the author, were rarely recorded and matrimonial regimes were left unclarified. It is, instead, the sexual laxity of lay Frenchmen living in Huronia that he denounced whilst, curiously, all other aspects linked to the presence in Huronia of his secular compatriots, more numerous than the missionaries themselves, were left out.

This 1636 report undoubtedly constitutes Brébeuf's most important piece of ethnographic writing. It was not a text written in full maturity, its author was by then only five years into the 15 that he would spend with the Hurons. Nevertheless, five years already constituted a generous amount of time in direct contact with his subjects, and his text reflects this familiarity in numerous descriptions and astute remarks. On the other hand, Brébeuf's explanations show the limitations of an observer coming from a European culture that had not yet started observing itself in a systematic way, one which, at the dawn of its colonial experience, still lacked the necessary distance to reflect on its own idiosyncrasies. Hence, our missionary could not possibly envisage Huron society with as much detachment as would have been necessary to understand the general economy of social behaviours, the truly ecological approach to nature, forms of reciprocity, animistic cosmology, and so on. Lacking the intellectual tools that his own society had not yet produced to analyse the Other in relation to the Self, lacking also sufficient methodological

${ }^{15}$ Mauss, Marcel. 'Essai sur le don. Forme et raison de l'échange dans les sociétés archaïques', Année sociologique, série 2, 1, pp. 30-186. 1923-1924. 
preparation (not a single reference is used besides the occasional evocation, for pedagogical purposes, of biblical and European Antiquity mythical characters), but above all, coming as it were too early in the history of European ethnography, Brébeuf did his best under challenging circumstances.

Brébeuf himself later became a subject for academic studies, as did his writing. ${ }^{16}$ Both Charlevoix and Lafitau, the 18th century stars of French missionary ethnography of the sauvages, quote him. Descendants of the Hurons in Canada today - French speakers in the majority - read his works and confirm that his observations were exact. But what matters most for us, is to keep in mind that at the time Brébeuf was writing his 1636 Relations, he was doing so at the request of his Superior and his intention was first to narrate his activities and that of his mission for the benefit of his colleagues and the moral edification of a select readership back in France. An additional, apparently very personal and probably unsolicited reason for writing ethnography arose from the need he felt to make productive use of his spare time and to inform his Jesuit colleagues on the culture of the Huron in order to make his successors' life less miserable and their work more effective. It is probably fair to say that Brébeuf did not harbour any scientific intention, or if he did, it was at best a very blurry, spontaneous one. The fact that he did not write a single follow-up piece, is probably the most telling sign of this.

Nevertheless, the point of this book is not to systematically exploit early New France missionary ethnography. As I stated earlier, my aim in doing this is to put in place a reference point to weigh up the value of the missionary ethnography that will be produced over two centuries later in the northern uplands of French Indochina.

${ }^{16}$ Cf. Talbot, Francis, s.j. Saint among the Hurons: The Life of Fean de Brébeuf. New York: Harper \& Brothers, 1949; Donnelly, J.P. Jean de Brébeuf, 1593-1649. Chicago: Loyola University Press, 1975; Trigger, Bruce. The Children of Aataentsic: A History of the Huron People to 1660. Montréal: McGill-Queens University Press, 2 volumes, 1976; Latourelle, René, s.j. Fean de Brébeuf. Montréal: Bellarmin, 1993. Kennedy, John H. Jesuit and Savage in New France. New Haven: Yale University Press, 1950; Latourelle, René, s.j. Études sur les écrits de saint fean de Brébeuf. Montréal: Éditions de l'Immaculée-Conception, 2 volumes, 1953; Thérien, "Intrtoduction." 


\section{The Golonial Heritage}

The Canadian opportunity contributed greatly to nurturing French and European thinking on civilisation and savagery. With Hobbes and Voltaire on the one side, and Rousseau and Montesquieu on the other, primitive society was acknowledged and gradually understood as either anarchic and bloody, or as a paradise lost. French philosophers of the Enlightenment all knew about Canada and the Native American ethnographic literature, they all had access to the published accounts written by all categories of observers, and their revolutionary contemplation of human cultural variety could be rooted in the systematic use of first hand accounts.

So, with such a promising start, why was French anthropology to virtually stall in the following century? Evans-Pritchard, with his History of Anthropological thought, ${ }^{17}$ had retained Auguste Comte as the sole meaningful French contributor to the evolution of anthropological thinking in the 19th century. Before Evans-Pritchard, French social scientist Marcel Mauss himself was no less harsh on the subject of French anthropology in the 19th century, stating in 1913:

Old [17th century] books by Jean de Lery and Marquess of Rochefort have more to teach us on who the Caribbean races belong to than all our works published in the 19th century. [...] One would have to look hard to find, in the 19th century in French language, a work of equal worth [to earlier pieces such as] Lesson's on Polynesians (Dumont D'Urville expedition). Compared with the work done in the 19th century by scholars in England, the United-States, Germany or even Holland, France could only show a sorry face. ${ }^{18}$

On the broad French political stage, the Revolutionary turmoil in the late 18th century followed by the imposition of Imperial rule and, in turn, the return to monarchy, all fundamental political changes taking place between the 1780 s and the 1820 s in war-ridden continental Europe, were followed by several popular upheavals and mini-revolutions. With the Industrial Revolution and the second phase of French colonial expansion both progressing at an accelerated pace, the times were less than conducive for French thinkers to carry-out detached thinking on ethnography, ethnology and anthropology.

17 Evans-Pritchard, A History of Anthropological Thought.

18 Mauss, Marcel. "L'ethnographie en France et à l'étranger." La Revue de Paris, vol. 20, pp. 537-60, 815-37, 1913, 538, 548, 550. 
More precisely, Mauss reckoned that the reason for France's poor performance in furthering its reflections on the ethnography of the sauvages after the 18th century lay with the fact that between the Seven Year War and the end of the Napoleonic adventure (from the 1750s to the 1810s), ancient colonies where France had sizeable native populations to administer were lost - namely New France, Louisiana, and the West Indies - and with them vanished the interest in knowing about primitive societies. In addition, this loss was endured concurrently with the abolition of the Jesuit order by the Pope in 1773 and a staunch anticlericalism that developed in the wake of the 1789 Revolution. On such thin soil, the young tradition of French missionary ethnography could only lose ground. Furthermore, in Mauss' words again, over the first three quarters of the 19th century, "a kind of general, social, reactionary and stubborn opposition hampered the progress of the Science of Man: Ethnography, as an auxiliary of anthropology, was still relegated with it to the margins of the French scientific movement." 19 As a consequence, it can not be just a coincidence if over the 19th century, ethnographic literature was nearly devoid of significant works produced in the French language.

To France's credit, with regards to more politically stable England, George Stocking has convincingly argued that even during the Victorian zenith of the British colonial empire, it was not before the late decades of the 19th century that the methods of ethnography, and thus the accumulation of the building blocks used in the construction of the disciplines of ethnology and anthropology, changed significantly from the form they had taken during the preceding century. ${ }^{20}$ Indeed, this statement is broadly true for most ethnography that was conducted in the Western world, where Darwinian evolutionism was the dominant intellectual influence following the Enlightenment in 19th century Western Europe.

Yet, the basis for the theoretical arguments of 19th century ethnologists and social evolutionists was still, as it had been for the philisophers of the Enlightenment, the ethnographic material found in books describing the experience of travelers, explorers, naturalists, missionaries, and colonial officials that continued to flow from the press. Stocking also points out the fact that much later, in the 1960s, the relationship

19 Ibid., 549.

20 Stocking, G.W. Jr. Victorian Anthropology. New York: The Free Press, 1987. 
between anthropology on the one hand, and colonialism and imperialism on the other, finally became, for the first time, a burning issue for anthropologists. ${ }^{21}$ The 1960s were a hotbed of change for Western social sciences, with the re-organizing of the world order in the midst of the Cold War, decolonisation, Third World nationalism, and ventures of neo-imperialism such as the so-called Vietnam War. Third World social scientists like Franz Fanon were raising their voices to denounce the new forms of Western infringement. ${ }^{22}$ This reshuffling of the world order had, among its many impacts, sudden complications for First World ethnographers attempting to access their 'traditional' fieldwork sites. Trouble was also brewing inside academia. In the West, a growing body of anti-imperialist academics was becoming increasingly outspoken. The discipline of anthropology itself came under attack from within its own ranks following the exposure of covert collaborations between some anthropologists and the American military intelligence in such enterprises as Project Camelot in Latin America in the mid-sixties, and the counter-insurgency movements in Mainland Southeast Asia a few years later. ${ }^{23} \mathrm{~A}$ fracture developed among anthropologists between the most vociferous supporters of the New Left rejecting any form of imperialism, and those practitioners of anthropology who stressed that they were acting in good liberal faith when ethnographying cultures in politically contested areas.

This shift of political power, and the growing numbers of those anthropologists opposing the dwindling crowd of pro-imperialism authors was certainly a positive evolution in the long run. Yet, according to some, stating that the works of anthropologists have been instrumental to imperialism is perhaps giving too much credit to anthropologists. In real political terms, as was soon to be recognized,

the role of anthropologists in maintaining structures of imperial domination has, despite slogans to the contrary, usually been trivial; the knowledge they produced was often too esoteric for government use, and even where it was usable it was marginal in comparison to the vast body of information routinely accumulated by merchants, missionaries, and administrators. ${ }^{24}$

${ }^{21}$ Stocking, George W. Jr. (ed.). Colonial Situations. Essays on the Conceptualisation of Ethnographic Knowledge. Madison: University of Wisconsin Press, "History of Anthropology" series vol. 7, 1991.

${ }_{22}$ Fanon, Franz. Les damnés de la Terre. Paris: François Maspéro, 1961.

${ }^{23}$ Cf. Wakin Eric, Anthropology Goes to War.

${ }^{24}$ Asad, Talal. "Afterword: From the History of Colonial Anthropology to the 
It was the non-academic producers of ethnography who, thus, were publicly outcast from the debate, with the stigma of collaborators in the exploitation of Man by Man being assigned to them by academics and forceful critics of imperialism.

Unavoidably, the debate on the historical and somewhat embarrassing relationships between anthropology and colonialism/imperialism is one that has haunted the discipline in the period from 1950 to $1975 .{ }^{25}$ At times, this debate took on the proportions of a real crisis due to the emerging assumption that anthropologists, with a specific academic formation dispensed by universities around the world, should take an ethical stance and keep a distance from the imperialist world order. In the hottest period of the anti-Vietnam War movement in the USA, in May 1971, the American Anthropological Association adopted for the first time its 'Principles of Professional Responsibility,' a code of ethics that has ever since tied its members to standard practices when conducting research involving populations at risk.

The fracture embedded in the professionalisation of anthropology, and with it ethnography, caused a separation between two groups of performers of ethnography. On the one side was a select group of academic anthropologists, relatively independent from their governments' policies and motivated by the high ideal of contributing to the better understanding of Humankind; on the other stood the cohorts of non-academic, amateur or semi-official ethnographers employed by the state or connected to it for purposes suiting the latter's agenda. Until relatively recently however, such a drastic categorisation did not take into account the huge grey zone separating the two extremes of this polarised spectrum, a zone where trained anthropologists could also be instruments of the state's exploitation/domination project by

Anthropology of Western Hegemony." In Colonial Situations. Essays on the conceptualisation of ethnographic knowledge, ed. George W. Stocking Jr., Madison: University of Wisconsin Press, History of Anthropology series, vol. 7, 1991, 314. See also James, Wendy. "The Anthropologist as Reluctant Imperialist." In Anthropology and the Colonial Encounter, ed. Asad, Talal, London: Ithaca Press, Atlantic Highlands: Humanities Press, pp. 42-69, 1973.

${ }_{25}$ Cf. Leiris, Michel. "L'ethnographe devant le colonialisme." Les temps modernes, vol. 6, no. 58, pp. 357-74, 1950; Balandier, Georges. "The Colonial Situation: A Theoretical Approach." In The Sociology of Black Africa: Social Dynamics on Central Africa. New York: Praeger, pp. 34-61, 1951 (1970); Leclerc, Gérard Anthropologie et colonialisme: essai sur l'histoire de l'africanisme. Paris: Fayard, 1972; Asad, Talal. "Introduction." In Anthropology and the Colonial Encounter, ed. Asad, Talal, London: Ithaca Press, Atlantic Highlands (NJ): Humanities Press, pp. 9-19, 1973; Lewis, Diane. "Anthropology and Colonialism." Current Anthropology, vol. 14, pp. 581-91, 1973. 
accepting its 'tied' research funding, and conversely, where non-trained ethnographers inside the state's machine could actually stand-up against its abuses.

The history of anthropology within colonialism/imperialism is approached today in a more mature, less emotional way and is incorporated as a subject matter of anthropological studies in universities throughout the world. The dust having largely settled, looking back at the anthropology of colonial times with a fresh eye is now feasible, credible, and for many, it is a necessity. Searching that period, its actors, its specific ethnographic production and the discourses crafted in the very peculiar context of the expansion of dominant 'Western civilization' serves an important purpose in the renewal of the discipline of anthropology. A sign of this renewed interest comes with the recent publication of volumes and review articles on colonial anthropology by many authors including Said in 1989, Bonsen et al. in 1990, Stocking in 1991, Pels \& Salemink in 1994 and 1999, Vermeulen \& Roldán in 1995, Pels in 1997, and Salemink in 2003. It is clear that more balanced critical analyses of colonial ethnographies have now joined the larger debates on ethnographic writing. ${ }^{26}$

${ }^{26}$ Cf. Said, Edward. "Representing the Colonized. Anthropology's Interlocutors." Critical Inquiry, vol. 15, pp. 205-25, 1989; Bonsen, Roland, Hans Marks, Jelle Miedema (eds). The Ambiguity of Rapprochement. Reflections of Anthropologists on their Relationship with Missionaries. Nijmegen: Focaal, 1990; Stocking, Colonial Situations; Pels and Salemink, Colonial Subjects; Pels and Salemink, "Introduction"; Vermeulen, H.F. and A.A. Roldán, eds. Fieldwork and Footnotes. Studies in the History of European Anthropology. London: Routledge, 1995; Pels, Peter. "The Anthropology of Colonialism: Culture, History, and the Emergence of Western Governmentality." Annual Review of Anthropology, vol. 26, pp. 163-83, 1997; Salemink, Oscar. The Ethnography of Vietnam's Central Highlanders. A Historical Contextualization 1850-1990. London: Curzon Press, 2003. 
Jean Michaud - 978-90-47-42021-7

Downloaded from Brill.com๑4/26/2023 $\odot 9: 56: 23 \mathrm{AM}$

via free access 


\section{CHAPTER FOUR}

\section{FOCUSING UPON THE CATHOLIC COLONIAL MISSIONARY TOWARDS THE END OF THE 19TH GENTURY}

The aim of this chapter is to examine the formation and education of French Catholic missionaries, the specific group of 'incidental' ethnographers that form the focal point of this book. To practice his trade, the ethnographer's main tool is his/her own personality combined with intellectual equipment. Subjectivity thus runs high in the early practice of describing the exotic Other - as indeed one can argue it still does today. In any case, for the missionaries considered here, faith, the institution of the Church, and loyalty to the motherland combined to produce a signature type of agency which we now examine.

To begin, I first turn to describe the circumstances of the Catholic missionary and then consider what made him distinct from other missionaries belonging to non-Catholic Christian denominations. I then examine the particular case of missionary education within the French Société des Missions Etrangères de Paris, the institutional home of our religious ethnographers. Finally, I explain how biographical information on these authors becomes necessary to accurately assess their texts.

Philosopher Jean-Jacques Rousseau was an early advocate of the benefits - for Europe that is - of embracing human diversity rather than trying to eradicate it. Rousseau suggested that studying human variety was a most important and necessary task. This task, however, as he wrote in 1762, was subject to methodological problems linked to what would later come to be known as ethnocentrism.

For three or four hundred years inhabitants of Europe are flooding other parts of the world and incessantly publish new travel accounts and diaries. I'm persuaded that all we know about Man is in fact only about Europeans. People may come and go but it appears that philosophy cannot travel, thus the philosophy of one people is not appropriate for another people. The cause for this is manifest, at least regarding far away countries: there is not much more than four categories of men who endeavour to travel to distant lands; these are sailors, traders, soldiers and missionaries; one cannot expect the first three classes to produce good observers, while as far as the fourth goes, busy with the sublime vocation that calls them, 
and supposing they would not be subject to prejudices like the others, one has to believe that they would not readily set on their research motivated purely by curiosity, which would detract them from the more important work they are destined to. ${ }^{1}$

Rousseau thus pointed to one of the most important problems linked to the observation of the Other: the observer's lack of adequate preparation. As a rule, missionaries sent to the colonies were not trained to conduct ethnography. In French Indochina, in the second half of the 19th century, these missionary agents still predated by more than half a century the popular availability in France of the specific formation on how to perform ethnography - which only occurred after the 1920s. ${ }^{2}$ Not only that, but these churchmen were not even exposed to the most common intellectual notions and assumptions that academics of their time shared; quite the opposite, they were often actively sheltered from them. Administratively as much as ideologically, the missionaries were embedded in, and dependant on, highly hierarchical institutions that had the first and last words on their work, their whereabouts, and some could argue, their mindsets.

If we give the term 'ethnography' the broad definition of the carrying out of systematic observations of human social behaviour in situ, and if we accept that an ethnographer is a person conducting such observations, then the missionaries within the colony of Indochina were definitely ethnographers, at least for a portion of their time. Self-awareness and reflexivity, two elemental virtues of modern academic ethnography, were extremely limited among colonial missionary ethnographers; in their particular context, it needed not be any greater. Actually, these men were not even apprentice ethnographers as their intention was not to learn the trade of the ethnographer. They also cannot be branded amateur ethnographers as again, their studies were not performed out of curiosity but served instrumental purposes, a sort of digging for facts geared to highly specific needs. Then, if we were to adopt the academic viewpoint that sees the formalisation of ethnography into its ultimate form - academic ethnography - as a progression on a continuum going from simplicity to complexity, we could stretch a

\footnotetext{
${ }^{1}$ Rousseau, Jean-Jacques, Oeuvres complètes. Du contrat social et autres écrits politiques (vol. 3, 1762). Paris: Gallimard, collection La Pléiade, 1964, 212.

${ }^{2}$ Menget, Patrick, "Histoire de l'Anthropologie." In Dictionnaire de l'Ethnologie et de l'Anthropologie, eds. Bonte, P. \& M. Izard, Paris: Presses universitaires de France, 328-332, 1991, 331.
} 
concept proposed by Leclerc and label these agents pre-ethnographers. ${ }^{3}$ However, using such a notion would mean that we implicitly accept the principle that academically-informed ethnography is of higher value than its non-academic forms, precisely the perception that I am careful not to promote in this book.

As introduced in Chapter 1, I like to use the idea of 'incidental' ethnography instead. By avoiding applying a label relative to an intellectual evolution through time, this notion is consistent with the suggestion that all forms of ethnography have merits in their specific contexts, without respect to the professionalisation of this activity. It also conveys the sense of these observers, otherwise busy with their chief duties, being accidentally dragged into this activity. A call of duty so to speak, to which they responded with a high degree of variation in their levels of commitment, competence, and precision. Clearly, this variation calls for an individualised consideration of 'incidental' ethnographers and their work in situ. Therefore, as a step in that direction, let us examine the background and the preparation of this very particular category of 'incidental' ethnographers that we are interested in, the Catholic missionary.

\section{The Catholic Missionary}

In comparison with the Catholic missionary universe, understanding the mind set of other colonial actors-cum-ethnographers requires less explanation since those observers and their world are somewhat more evident. They have been studied for longer, particularly the categories of colonial explorers and state representatives, including the military. ${ }^{4}$

\footnotetext{
${ }^{3}$ Gérard Leclerc, Anthropologie et colonialisme: essai sur l'histoire de l'africanisme. Paris: Fayard, 1972. See also the parent notion of "pre-ethnology' proposed by Poirier, Jean. "Histoire de la pensée ethnologique." In Ethnologie générale, ed. Poirier, Jean. Paris: Editions Gallimard, Encyclopédie de la Pléiade, pp. 3-179, 1968.

${ }^{4}$ Cf. Jean Copans, Anthropologie et impérialisme. Paris: Maspero, 1975; Henri Eckert, Les militaires indochinois au service de la France (1859-1939). PhD dissertation in History, Université de Paris IV (France), 1998; Stephan Feuchtwang, "The Colonial Formation of British Social Anthropology." In Anthropology and the Colonial Encounter, ed. Asad, Talal, London: Ithaca Press, Atlantic Highlands: Humanities Press, pp. 72-100, 1973; Gerald C. Hickey, Sons of the Mountains. Ethnohistory of the Vietnamese Central Highlands to 1954. New Haven and London: Yale University Press, 1982a; John Kleinen, "Ethnographic Praxis and the Colonial State in Vietnam." In Viêt Nam. Sources et approches, eds. Lefailler, P. and J.-M. Mancini, Aix-en-Provence: Université de Provence, 1996; Gérard Leclerc, Anthropologie et colonialisme: essai sur l'histoire de l'africanisme. Paris: Fayard,
} 
In addition to being a complex universe in itself, the specificities of the Catholic Church regarding the formation of the missionary and his actions in the field demands some explanation.

Contrary to Protestant ministers or pastors of various denominations for whom the separation from the larger body of the Catholic Church at the Reformation entailed drastic changes in the ways and lives of the working members of the Church, Catholic friars, deacons, priests, and bishops from continental Europe operating in the colonies were invariably celibate and male. Along with other particularities that will be addressed in the next pages, this fact has far reaching implications when studying the contributions of these men to ethnography. We will start here by considering the distinctiveness of Catholic missionary preparation, context, and work as a preliminary step to assessing the influence these idiosyncrasies may have had on their texts. To keep this exposé within reasonable limits, it is specifically the late 19th century French Catholic traditions that will be addressed, which bore many similarities with other Western European Catholic colonial traditions such as in Spain, Portugal, Italy, and to an extent, the Netherlands and England.

First, we turn our attention to the formation years. The education of a Catholic missionary constituted a fundamental stage in his development, one that would determine his social character and provide him with an intellectual foundation. In the French Catholic tradition, young boys seen by their parents or relatives as prospective religious recruits were sent to provincial petits séminaires, minor seminaries, also called preparatory seminaries, around the age of 12. The preferred candidate was usually born into a rural family and showed dispositions for introspection and studies, and perhaps not much inclination for agricultural work. More often than not, however, he was merely the first-born son in the house. In addition to the not insignificant benefit of having one less child to feed, peasant parents would also agree to this course of action because they believed that the whole family would gain merit from such sacrifice. The parents would also ensure one of

1972; William H.R. Rivers, "Report on Anthropological Research outside America." In Reports upon the Present Condition and Future Needs of the Science of Anthropology, eds. Rivers, W.H.R., A.E. Jenks and S.G. Morley, Washington D.C., pp. 5-28, 1913; Edward Said, "Representing the Colonized. Anthropology's Interlocutors." Critical Inquiry, vol. 15, pp. 205-25, 1989; Oscar Salemink, The Ethnography of Vietnam's Central Highlanders. A Historical Contextualization 1850-1990. London: Curzon Press, 2003; G.W. Stocking Jr., Victorian Anthropology. New York: the Free Press, 1987. 
their children would have a more secure future than what rural life, with all its uncertainties, could offer.

During the first few years of general education in the minor seminary, some of the adolescents would be sent back home for lack of the required temperament and qualities; some would simply quit due to an incapacity to adapt to religious life. Others would elect to stay with the congregation for the long term, completing their studies and devoting their life to simpler matters like providing primary education to pupils or the material maintenance of the seminary and the congregation; these were the frères (friars), who were not ordained priests, and did not normally go on missions. And, there were others, young seminarists contemplating the higher state of priesthood or even missionary life, who would be sent to a grand séminaire, a major seminary, also known as a theological seminary, for further studies, with one major seminary usually operating in every diocese. There, for four more years, the novice would complete his education and prepare for a life fully dedicated to apostolic work, either at home or elsewhere, since at this stage, whether the candidate would eventually be a parish priest or become a missionary abroad was not yet decided. General formation was still the main item on the educational agenda. For example, in the late-19th century, the curriculum at the major seminary of the Société des Missions Étrangères de Paris, on the corner of Rue du Bac and Rue de Babylone, blended various elements reflecting the union between Catholic religious tradition and French Republican values. Studies included arithmetic, antique philosophy, antique languages such as Latin and Greek, theology, Christian philosophy and moral doctrine. These studies were accompanied daily by four or five collective prayers and a mass, as well as collective meals and moments of solitary contemplation. Learning the rites and the history of the congregation and participating in its spiritual and material life were also required. In lesser as well as in major seminaries, topics that were not approved of by the almighty Vatican censors were carefully kept out of the curriculum. All written sources the students had permission to lay their eyes on were carefully screened, and the prospects for a particularly curious candidate to expand his knowledge on such topics as non-religious travel writing, Darwinism, or the ethnography of the Savages, were tantamount to nil - at least within the walls of the seminary.

In such seminaries, direct or indirect contact with the secular world was restricted and during all his years of training, the seminarist would rarely see even his family. Brief and most often yearly visits would be 
allowed for close family members in the seminary's parlour, while leaving the compound altogether would only be permitted for specific duties or for attending important family events such as weddings and funerals. On the whole, the young priest in the making was confined within the physical and intellectual ramparts of his seminary.

Diocesan major seminaries varied in importance, shape, atmosphere and tradition not only between religious denominations - such as Ordre Dominicain (Ordre des Prêcheurs, OP), Oblat de Marie-Immaculée (OMI) and Congrégation du Très-Saint Rédempteur (CSsR), present in other parts of French Indochina- but as well within one given denomination. For instance, larger establishments located in prominent cities would offer more opportunities for socialising than smaller ones in the countryside, not only because of the former's proximity to population centres but also because these would be the preferred choices for wealthy families to send a child of their own. This selection process brought additional depth to in-house discussions and debates among young novices who also had more numerous opportunities to glimpse into the lay world while, for instance, accompanying a senior colleague 'into the world' to perform some logistical or religious duty.

Upon graduating from the grand séminaire, which most of the times meant that the candidate had just been ordained to priesthood, which happened towards the end of his training, the question of his final destination was raised. The young man was asked to choose his path. Although recruits may have voiced their preference much earlier and made it known to all, it was at this point that they could officially opt for missionary life. If not educated in a seminary specifically dedicated to missionary work (in which case they were now ready to leave on their assignment), the young priests could ask to be sent to such a place. These seminaries, where the young men would reside generally not exceeding one year, were suppliers of Catholic missionaries to the colonies. Among these providers stood the Société des Missions Étrangères de Paris (MEP). Being entirely devoted to missionary work abroad, not only did it accept fully formed priests wanting to become active in its missionary network, it also was a training ground for younger candidates on their way to priesthood. In the cases when adolescents graduating from minor seminaries showed an early determination to enter missionary life, the MEP would operate as a major seminary, hosting such pupils for the full four-year formation leading to priesthood. These students were then included in the larger crowd of priests-cum-missionary candidates coming to the MEP from all over the country. Together, 
these students were given a one-year preparation devoted to learning about the precepts and history of the MEP and the development of its overseas missionary activities since the 17 th century. Then they were sent away on their mission. It is important to note that even at this late stage in their formation, only weeks away from actually boarding the ship that would take them away, the missionaries-in-the-making were still unaware of their exact destination and thus, they could not undertake any specific historical, cultural, or language studies while still in France.

Why, one is tempted to ask in today's fast moving world, would a young priest from late 19th century France, coming most often from the countryside and unexposed to the larger world, accept a one-way ticket to an uncertain future far from home, and ignore safer and more comfortable options like priesthood in a homeland parish, teaching in a seminary, or perhaps staying at the MEP headquarters to take up some administrative task? This resolve and dedication of a young missionary may seem hard to grasp, it may even appear dramatically naive. At the time however, it went without saying.

First, there was the very nature of the missionary societies. Some of them, like the MEP, had no other raison d'etre than to produce missionaries. The more priests that the society sent abroad, the more prestige it gained, and the more donations it received from devotees to support its activities. The atmosphere within the missionary seminaries was thus conducive to seminarists wishing to reach this sublime objective of being sent abroad and spread the Word of God to the Pagans. Social origin was another decisive factor. Most of the candidates came from humble social backgrounds where the traditional notions of sacrifice to God, family, and the Nation were widely accepted values. In contrast, the wealthy families of candidates from higher social origins were more likely to ensure that their heir steered safely away from physical danger and remained closer to home. But beyond such objective factors, for the hardcore candidates of missionary life, total dedication to the simple destiny of 'labourer of God' in a foreign and hostile country was above all the surest way to make His Kingdom come and to press forward towards sanctity.

The braver ones among the young candidates were also fuelled by an irrepressible desire to follow the brothers of yesteryears whose names and memory were solemnly revered in the missionary community. Indeed, there was a regiment of sanctified predecessors, each of whom were ostentatiously displayed in grand pictures hung high on 
every available wall of the seminary, in sculptures set up on pedestals in every chapel, garden and cloister, in engravings adorning missals, or represented in pious images kept close to one's heart or on a bedside table. Some were depicted in the blissful presence of God, others in the gruesome agony of martyrdom, on their way to sitting on the right of Christ, the first among martyrs. Letters sent by French missionaries from various colonial locations regularly referred to the glorious and much enviable opportunity for martyrdom that could be looming on the horizon. Although a degree of apprehension was certainly a common occurrence among missionaries, the possibility of dying in the most atrocious circumstances while devoting body and soul to advancing God's project was generally not dreaded, instead it offered a path for the 'true' missionary to accelerate his pace towards an enviable fate in Paradise. Those who had been granted the 'joy' of becoming martyrs were elevated back home to the pinnacle by their community; their lives were cited and studied as models, the circumstances of their violent death told again and again. ${ }^{5}$

In 1842 at the MEP headquarters in Paris, this serene form of fascination with death led to the establishment of a permanent exhibition in a salle des martyrs, still open today, a room where were put on display various artefacts that pertained to those MEP members who died brutally. ${ }^{6}$ This was orchestrated so that future generations of recruits could be enlightened by the contemplation of graphic representations of their elders' torment and touch objects that belonged to them. In the 19th century, with the anti-Christian religious movements in Vietnam reaching their peak, dozens of French missionaries and scores of Vietnamese converts and proselytes were put to death by Vietnamese rulers. To deter the population from following the bad example of their 'deviant' brothers and sisters, the execution of a foreign priest in particular had to be public, exemplary, and violent. However, as gruesome as these demonstrations were, they often backfired. Paintings of the capital punishments were made by eye-witnesses and accounts were written. These were then copied and secretly circulated among

${ }^{5}$ Thus for instance, Jean de Brébeuf whom we've met in Chapter 3, was beatified in 1930 by Pious XI and appears today as one of only two historical characters worthy of representing his town of origin on the communal website of Condé-sur-Vire, Normandy (http://www.conde-sur-vire.com). His short biography explicitly states that he died a martyr.

${ }^{6}$ http://128.mepasie.org/salle-des-martyrs-presentation.fr-fr. 1 1..contents.htm 
converts. The martyrs became the objects of special reverence among their flock as their example was spun into a source of emulation. Meanwhile in Paris, the individual displays in the salle des martyrs grew accordingly in number and importance. By the end of the 19th century, they had reached dramatic proportions that impacted profoundly on the psyche of the seminarists preparing for their departure. Faced with such forceful glorification of the martyrs, and still remote from the sensorial displeasure of such a miserable end, the earnest would-be missionaries were understandably tempted to follow in these bloody, yet inspirational footsteps.

The choice of apostolic destination for each new missionary generally depended on the Society's commitments at that moment, on the financial and political support from benefactors, and obviously, on the current colonial politics. As far as the religious establishment was concerned, exactly how many neophytes would be sent to one particular colonial vicariate in any given year was determined by the number of new recruits available combined with the requests for help received from bishops in their overseas missions. A few weeks before their departure, which usually occurred in summertime, all the new priests would solemnly gather in the seminary's common room and hear from the assembly of directors what was in store for each of them, their individual name and assignment being publicly called from a role. According to accounts left by recruits, this is when their emotions of expectancy and excitement were at an all time high. ${ }^{7}$

About to leave their homeland permanently, the young men bade farewell to their families and asked for their blessing in the face of the hardships awaiting them. Unlike Protestant missionaries who would occasionally go back home on furlough and were entitled to contemplate retirement in the homeland, Roman Catholic missionaries were all conditioned and geared to spending the rest of their life abroad without the prospect of ever returning home. ${ }^{8}$ In hometowns where the young priests were allowed to visit their family one last time, farewells were, accordingly, a mixed bag of bouts of elation and heartbreaking moments.

\footnotetext{
${ }^{7}$ For a contemporanous narration of that event, see Monteuuis, Gustave. L'âme d'un missionnaire. Vie du P. Nempon, missionnaire apostolique du Tonkin Occidental. Paris: Victor Retaux et Fils, 1895.

${ }^{8}$ In the case of the MEP, such comfort as occasional visits to France would only be introduced in 1922 (Guennou, Jean. Missions étrangères de Paris. Paris: Fayard, 1986).
} 
Continuing to consider the objective and ideological conditions of the French Catholic missionary's work on assignment in colonial Tonkin, and particularly in highland Tonkin, we reach the important step of his insertion into, and adaptation to, a new setting where his personality and his training will be turned into praxis in the mould of a physical and cultural confrontation with the host society and the 'pagan' Other.

Initially stationed at the vicariate's headquarters, one of the first tasks for the missionary was to learn spoken and written Vietnamese, the dominant vernacular language. For West and then Upper Tonkin, these headquarters were located south of the capital in Keso prior to 1885 , or, between 1885 and 1895 in the MEP Hanoi enclave and then, after 1895, at the Upper Tonkin vicariate headquarters proper in Hung Hoa. Concurrently, the newcomer's participation in simple missionary work nearby in the company of older colleagues contributed to his becoming acquainted with the local customs while facilitating his acclimatization to the tropical environment. After a time period that varied according to local conditions, lasting roughly one year, the apprentice was then ready to be dispatched to his first formal apostolic assignment. Depending on his personality, keenness, linguistic proficiency, and talent, his Bishop had a choice between several locations requesting help and requiring varying degrees of survival skills and political finesse. Commonly, a newcomer would first be assigned to a well established lowland mission outpost among the Kinh where he would 'learn the ropes' in the company of more seasoned colleagues. Later, the capable ones among this young crowd could be reassigned to more demanding tasks, such as opening a new mission in the uncharted uplands. In this case, a clear connection existed between the need for this particular apostolic assignment and the colonial military agenda of winning territories and controlling populations, as Bishop Puginier's agency will aptly illustrate in Chapter 6. For the colonial authorities in Hanoi as much as for the religious ones, a crucial task of the despatched missionary was to be the eyes and ears of the colonial structure among the natives.

In terms of daily affairs and accountability, the priests in each local mission were under the direct responsibility of a senior colleague in charge of that particular mission, who would in turn report to the Bishop in charge of the vicariate. Bishops chosen by the MEP Board of Directors in Paris and commissioned directly by the Pope were given substantial authority, with political imperatives as well as moral, 
financial, and managerial ones. ${ }^{9}$ Lower in the religious hierarchy, the simple missionary sent to outposts in the highlands had to nurture more humble aspirations. Often the only non-military European present in a vast territory apart from the occasional trader or custom officer, he would tend to be attached to French troops in a regional town. At other times, beyond the Red River delta's lowlands, he might be sent to a more remote location to live among the natives. There, his life as an outsider in a drastically different culture was a solitary one in spite of the few Vietnamese aids he could take with him on his assignment. Mastering Vietnamese and, in many cases, learning a regional vernacular language was a crucial requirement if he was to be able to communicate and hope to survive. In upper Tonkin, vernacular languages differed drastically from the Vietnamese they had learned in the lowlands. In these uplands, as in Huronia two centuries earlier, missionaries had no other choice but to give first priority to the linguistic chore. Since some among them were only sporadically in contact with France's colonial representatives, they had to 'make it' in the company of their hosts. For that purpose alone, it was imperative that isolated missionaries mould themselves to the local ways of life.

For the missionary in the field, writing his observations on his hosts, at times actively seeking information in connection with a matter of specific interest that he was asked to keep an eye on for the colonial apparatus, and successfully securing letters back to the vicariate's see, was a mission in itself. These reports were to be performed with various

\footnotetext{
${ }^{9}$ Formerly, in the 17th and 18th centuries, bishops were commonly appointed from the outside, often by the King. Many had aristocratic origins, strong political backing, and solid patronage from one or several wealthy benefactors. Far from the homeland and the eyes of their directors, their political power and freedom to manoeuvre was important, and the material benefits substantial. In pre-colonial Vietnam, Jesuit Vicar apostolic Pigneau de Behaine became a trusted counsellor at the court of Nguyên and brought decisive support to the future emperor Gia Long by taking his case to Louis XVI in 1787 (Hall, D.G.E. A History of South-East Asia. New York: St-Martin's Press, 4th edition, pp. 449-54, 1981). Jesuit François de Montmorency de Laval, an early MEP member and the first bishop of Canada in the late 17th century, converted enormous surfaces of forest granted to him by the colony's Governor, into farmland for the benefit of his congregation. With money given to him by his aristocratic supporters in France, he also built a hospital and a seminary. He was a de facto member of the Sovereign Council and as such, part of all political decisions regarding the conduct of the colony's affairs. In the 19th century however, a democratisation of promotion from within missionary congregations lead to bishops being recruited from the ranks and files more often, which was the case in Tonkin in the late 19th century.
} 
degrees of regularity depending on the magnitude of the events reported and the strategic importance of the population he was attached to. On the other hand, besides the usual task of converting the natives, the missionary was also expected to convey messages to his hosts from the colonial authorities and encourage compliance with the laws and decrees - taxation, military draft, implementation of specific crops, and so on. In addition, once a year, the MEP missionary was also expected to produce a chronicle of life in his mission and submit it to his superiors. The Episcopal authorities would then draw out from this raw material whatever was of a political nature or could be useful in the management of the colony, and submit the results to the civil and military colonial authorities. Then, in a process on which we will expand in the remainder of this book and that was comparable to the Jesuit Relations described in Chapter 3, the rest of the chronicle's content was edited and blended with those from other missionaries in the same vicariate, and published in the form of yearly comptes-rendus (accounts or reports). As we will see in this book, more prolific authors could also publish individual articles in missionary journals, while a select few went on to publish scholarly pieces, which were most often also screened and approved by their superiors.

With ongoing war, conquest, resistance, rebellions, and spying on each other inevitably tainting the relationship between natives and outsiders in colonial Indochina, it is easy to realize that most native groups did not like always having a European observer so close to home all year long, let alone one who could understand their language and report on their private conversations. As such, the hosts were exposed more than they wanted to the outsider's gaze without being able to prevent sensitive information from leaking out. Most native hosts knew perfectly well what their guests were doing, but assessed the risk was still worth taking. Many saw the political benefits stemming from having a resident representative of the colonial state at hand. Lineage-based groups in particular, without a central authority and with active internal fractures between competing lineages and clans, did not present a unified front regarding the local missionary. Indeed, vying parties would constantly attempt to win the missionary to their cause and use him as an ally against their foes or competitors.

In cases when factions were fiercely opposed to a missionary's presence, this dramatically increased the hardships of the ministry and in moments of crisis, could result in the death of the intruder. Thus, aware of living on a tight rope and needing to make his presence acceptable 
to the largest possible number of natives, the missionary would perform a constant and delicate balancing act, and as a precaution, devote a lot of his time to performing good deeds in the village. This could involve helping to cure as many ill people as feasible, contributing to economic activities such as agriculture and hunting, or playing the role of advocate with the colonial authorities whenever necessary. Indeed, at times missionaries only stopped short of participating actively in warfare and taking a local spouse...

When sufficiently well established, the missionary assigned to remote locations and populations was invariably used by the colonial system in several additional ways. He and his mission would serve as hosts for visiting colonial parties (diplomats, scholars, traders, or wealthy travellers), and as linguistic and cultural interpreters for scientific, trade, and military expeditions. In fact, virtually every expedition to remote areas of French Indochina and Yunnan would stop over in isolated missions, where a bearded priest in a robe would be happy to entertain European company for a short time. Expedition leaders would sometimes enrol the skills of their host for one or several legs of their journey. Well known cases from the MEP include Paul Vial, based just across the border in southern Yunnan, who led British explorer Archibald Colquhoun into upper Burma in 1882, and Jean-Baptiste de Guébriant who guided the D’Ollone Mission across Sichuan in 1907. ${ }^{10}$

MEP missionaries in Indochina were thus living a slow paced life, yet not one exempt from dangers. On average, in the course of their careers, they would move around a few different locations according to their competence and the needs of the missionary society (and the colonial state). If they lived to see old age, some would elect to finish their life among their converts, while others would return to their vicariate's headquarters and complete their mission in relative tranquillity. A good example, though not an entirely typical one, is that of Paul-Marie Ramond, who had arrived in Tonkin in 1881 at age 26. He was assigned to various postings for about 10 years before being appointed as the first Bishop of the Upper Tonkin vicariate in 1895. He retired from his Episcopal duties in 1939, and stayed in Tonkin to die of old age in 1944. Following his will, he was buried in Chapa, a

${ }^{10}$ Colquhoun, Archibald R. Across Chrysê. A Fourney of Exploration through the South China Border Lands from Canton to Mandalay. London: Sampson Low, Marston, Searle and Rivington, 2 volumes, 1883; D’Ollone, Henri. Langues des peuples non chinois de la Chine. Mission d'Ollone 1906-1909. Paris: Ernest Leroux, 1912b. 
colonial hill station and a missionary post he particularly cherished. His grave, recently restored, can be found behind the church.

$* * *$

The training period for a MEP missionary, as in most other French Catholic missionary companies, formed the key intellectual features of this potential ethnographer. First, on the psychological front, the young man had severed the emotional ties with his family and, to a certain extent, with the outside world as he had known it, to become a permanent and obedient member of a discrete social system, a hierarchical institution with God, and his champion the Pope, at its top. In all the years spent at the seminary, the would-be missionary was relentlessly immersed in an ideological universe where truth was wellknown, and uncertainty non-existent - at least when it applied to the world order and to moral principles. He was educated in rigorous terms compared to most of his contemporaries, with an emphasis on the rigid application of the rules rather than critical thinking. He was literate and thanks in particular to the study of religious philosophy, he could produce logical and well structured arguments, but rarely unprejudiced ones. It is difficult to assess what was left of his individual educational heritage from prior to his insertion into the formal religious education system. However, it is doubtful that this residue was very important in intellectual terms, unless the candidate came from an elite social background, which was rare among 19th century MEP recruits. For most, the intellectual legacy of their family would be of minor relevance to a future life in the colonies compared with the inbuilt provincial or rural habitus internalized in early childhood. Early and deeply ingrained, this pragmatic, empirical knowledge underpinned a down to earth, commonsense approach to the daily matters of life, which would become a priceless adaptive asset when the priest would need to survive and relate to his hosts in alien and isolated peasant hamlets.

With this knowledge of the missionary's education and, later, his life in the mission, what can be said of him as a potential ethnographer? On the bright side, the missionary's foremost strengths were undoubtedly the familiarity he could gain with the local population and their circumstances, thanks to the sheer length and intensity of his stay. In addition he had linguistic proficiency, and a status as a relatively harmless alien compared to most other categories of colonists in the highlands. As a producer of text, his duty to send regular reports to his superiors must have encouraged him to find something meaningful to 
say about the locals, thus forcing him to observe them. In addition, the rather extreme mindset developed during his training years made him virtually undeterred by harsh circumstances and immediate physical danger. Crucially, the severing of the emotional links with his homeland and family turned him into an enduring member of the institution, ever ready to serve. Indeed, contrary to administrative or military personnel, the missionary did not even nurture the desire to be sent home when a posting was completed or after a particularly demanding assignment. In one word, as an ethnographer, the MEP Catholic missionary of colonial times was in a vantage point to produce distinctive and exceptional observation pieces.

The evident weaknesses of the Catholic missionary as an ethnographer, as was recorded later by quite a few academic and religious authors, were his near-total deficiency in cultural relativism, his lack of cross-cultural education, and the fact that his morality would constantly infringe upon his judgement. In other words, like most of his contemporaries outside of religious life, he did not conceive of the 'savage' Other as a fully developed human, nor of tribes as apt forms of social organization. Cultural relativism was absent. His essentially patronizing agenda was set on doing what was 'right' to elevate the moral condition of the uncivilized to suitable levels of civilization. His missionary biases extended to him siding politically, consciously or not, with the colonial project, even if a number of recorded cases have convincingly shown that in specific circumstances, missionaries could also encourage natives to stand up against abuse by the colonial administration. He was made to wear intellectual blinders during his religious education, carefully sheltered as he had been from the necessity of having to develop a critical opinion on politics and social issues. His mindset was not geared towards learning, but towards teaching; so as a rule, on location, most missionaries only accepted to take in what they perceived as likely to make their teaching more effective. Often left to himself amongst the natives of his ministry, the lone apostle often did not have the opportunity to debate his observations and share his thoughts with a likeminded counterpart, and was inclined to reflect only within the limited boundaries of his own persona. Even among the most learned of these men, limited critical intellectual preparation combined with the absence of extra stimulation led to conclusions and generalizations that still baffle the scientific mind. Finally, on the darker side, he could easily be depicted as the ultimate political emissary to remote lands and little known peoples. His total commitment to the colonial institution 
secured - that task was in large part the duty of the religious institution, even if this was done less convincingly in times when profound disagreement between civilian and religious leadership threatened this alliance - he was the perfect scout, the eyes and the ears of the colonial system on the margins of the empire where the colonial machine could only reach with appreciable difficulty. He was one of the state's cheapest, most effective and efficient political and cultural spearheads and as such, his actions undeniably left a wound in the flank of every upland society he lived among and missionised.

As tempting as it has been for many authors to envision the French colonial Church as a radical, authoritative and inflexible body, it is difficult to ignore that it also harboured a capacity to be genuinely discerning. As a proof of this potential one finds the oft-quoted instructions - based on the 1659 principles promoted by the Roman Propaganda (the Congregation for the Propagation of the Faith), the moral authority for Catholic missionary initiatives outside Europe - that were read to every MEP young missionary leaving France in the late 19th century. These were a set of thoughtful recommendations indicative of a much less aggressive strategy than the stern critics of the Catholic missions have often suggested. It read:

Do not put any zeal into, do not promote any argument aiming at convincing these peoples to change their rites and their customs, unless of course these are contrary to moral and religion. What would be more absurd than to carry to the Chinese the ways of France, Spain, Italy or any other country of Europe? Do not introduce our countries to them, but introduce faith, the faith that does not repulse nor harm other peoples' rites and customs unless these are undesirable, but on the contrary faith that keeps and protects them. It is, as it were, part of any man's nature to esteem, love, and place above all others the traditions of his country, and the country itself. Conversely, there is no more powerful cause of separation and hatred than bringing changes to a nation's specific customs, especially customs whose practice goes back in time as far as the elders can recall. What would be the consequence if, after discarding them, you were to replace them with customs from your own country, brought from the outside? Thus, never compare traditions of these peoples with those from Europe: on the contrary, be swift in getting used to theirs. Admire and praise what deserves to be praised. As for what does not, and if it is appropriate not to praise it with flattery, be cautious not to judge or condemn mindlessly or excessively. Regarding the decisively wrong habits, one should fight them with head shakes and silence rather than with words. ${ }^{11}$

${ }^{11}$ Cited in Guennou, Missions étrangères de Paris, 74, my translation. A different trans- 
What actually remained of such open mindedness once a missionary reached the field is of course another matter - not to mention defining what qualified as 'wrong habits'. Yet overall, such cautionary remarks made to the new missionaries about to enter the field were laudably balanced and give an indication of the evolution that the Catholic Church had undergone after a period of difficult and often fruitless proselytizing abroad.

\section{On the Relevance of Biographies}

Before embarking on a review of missionary texts from Tonkin in the next chapters, a word is needed to explain why I will establish biographies of individual missionary authors in as much details as feasible prior to examining the production of their written work. These details may at times seem to bear little historical significance - actually, this will be the case for most of them. However, there is a rationale for not losing sight, in our analysis of their texts, of their backgrounds and frames of mind.

One of the most explicit conclusions triggered by the meeting of anthropology and post-modernist thinking in the 1980s was that the traditional objectivity of the ethnographer had to be questioned, that is, that all ethnographic texts are constructs. ${ }^{12}$ Therefore, the personality of the ethnographer, his/her past, education, career, intentions, and emotions cannot be brushed aside when assessing the value of the ethnographic text she or he has produced. In the cases being studied here, the need to explore the 'incidental' ethnographers' biographies is further compounded by the fact that these authors did not belong to the academic field, and therefore, as has been shown in this chapter, lacked its intellectual training and standardised methodology - albeit they had been taught philosophy, ethics, etc. Instead, they thought without patent uniformity, they were not as homogeneous in their appreciation of reality as, say, the military, their early individual lives were all distinctive, and their careers in Asia took them in a number of different directions. These variations left their mark on the texts,

\footnotetext{
lation can be found in Burridge, Kenelm. "Missionaries and the Perception of Evil." In Missionaries, Anthropologists, and Cultural Change, eds. Whiteman D. and F. Salomone, Williamsburg: William and Mary College, Studies in Third World Societies nrs. 25 \& 26, 2 volumes, 1983, 153.

${ }_{12}$ Clifford, James, and George E. Marcus (eds). Writing culture: The poetics and politics of ethnography. Berkeley, CA: University of California Press. 1986.
} 
the roots of that influence digging into each priest's separate past, and could be felt at every step from the data collection to the final editing of their written prose.

Some simple examples of biographical information from colonial Indochina that influenced the production of ethnographies may help to illustrate the relevance of taking note of the backgrounds and details of these individuals. Father François-Marie Savina, whom we will meet more at ease in Chapter 8, came from rural Brittany, a region whose inhabitants had long been defiant of the capital, Paris. Savina grew up speaking the Breton minority language, French coming second. This helps clarify why he developed an immense interest in linguistics, and sensitivity for highland minority cultures. As a non-missionary example, military commander Émile Lunet de Lajonquière, who in 1904 authored a major ethnographic report on upper Tonkin, had become a close friend of scholar Louis Finot after they had met on a ship taking them both from France to Indochina in 1899. At Finot's invitation, both men toured Indochina together for over a year. This friendship played a key role in the selection of the Commander by the École française d'Extrême-Orient, founded and directed by Finot, to produce the seminal Ethnographie des Territoires Militaires in spite of the fact that other officers in Tonkin might arguably have been better qualified than him to put this book together.$^{13}$ In another case, military officer Auguste Bonifacy had a degree in Chinese language before coming to Tonkin. This is the main reason why he was to become an expert of the Man tribe - today better known as the Dao, Yao or Mien - which happened to be a montagnard group of Tonkin using Chinese script for their ritual texts, parts of which Bonifacy went on to translate and study in a scholarly fashion. And finally, Colonel Henri Roux published in 1954 a much cited book on the ethnic minorities of Upper-Laos, Quelques populations du Nord Indochinois. ${ }^{14}$ In fact, it was over 30 years earlier that Roux had been in that region, and he wrote his book in good part from memory once he had retired in France. Nearly blind since 1945, he could still write, but could not read his old notes or his own manuscript, which was edited largely by an assistant who incorporated unplanned flaws. Used as illustrations to make a point, none of these biographical details is of

${ }^{13}$ Émile Lunet de Lajonquière (Commandant). Ethnographie des territoires militaires. Hanoi: F.H. Schneider, 1904.

${ }_{14}$ Roux, Henri (Colonel). "Quelques populations du Nord Indochinois." France-Asie, vol. 92-93, 1954. 
truly crucial importance. However, the accumulation of such elements, when taken into consideration and put in context, reveals a distinctive intellectual signature for any given author. Combined with additional elements regarding educational background and career contingencies, this signature helps deconstruct the texts and interpret the pieces.

However, obtaining a sufficient amount of biographical information on people who did not leave a vital mark on history can prove somewhat difficult. None of the missionary ethnographers who will be presented in the following chapters have been the subject of a formal biography, unlike for instance French Protestant missionary Maurice Leenhardt whose life and work in New Caledonia were analyzed by James Clifford..$^{15}$ Researchers are thus forced to dig deep in order to find nuggets of biographical information scattered amongst in-house obituaries, occasional comments published by contemporary observers and colleagues, or the infrequent detail given by the ethnographers themselves in the course of their text. A 'who's who' of French Indochina up to the early years of the 20th century, Brebion's Dictionnaire de bio-bibliographie générale, ancienne et moderne de l'Indochine française has been priceless in helping to grasp the little that was recorded about many a character who remained backstage during the Indochina colonial performance. ${ }^{16}$

Therefore, for me, the challenge has been to attempt to build a biography from scratch for each important ethnographer considered in the following chapters, filling in the blank spaces by superimposing biographical sketches over the background portrait of the institution that they belonged to in the particular historical time period that they lived. This is why I have presented in this chapter the structure of missionary education and the characteristics of life in the colonies in some detail. And whilst a degree of conjecture is inevitable, it has been kept to a strict minimum.

${ }^{15}$ James Clifford, Person and Myth: Maurice Leenhardt in the Melanesian World. Berkeley: University of California Press, 1982.

${ }^{16}$ Antoine Brebion, Dictionnaire de bio-bibliographie générale, ancienne et moderne, de l'Indochine francaise. Annales de l'Académie des Sciences coloniales, Vol. VIII. Paris: Société d'éditions géographiques, maritimes et coloniales, 1935. 
Jean Michaud - 978-90-47-42021-7

Downloaded from Brill.com๑4/26/2023 $\odot 9: 56: 23 \mathrm{AM}$

via free access 
PART THREE

UPPER TONKIN 
Jean Michaud - 978-90-47-42021-7

Downloaded from Brill.com๑4/26/2023 $\odot 9: 56: 23 \mathrm{AM}$

via free access 


\section{CHAPTER FIVE}

\section{EARLY GONTRIBUTORS TO THE ETHNOGRAPHY OF UPPER TONKIN}

In Part 3, we are firmly setting foot in and around colonial Tonkin. In the upcoming two chapters, we will meet some of the men whose agency contributed to the expansion of Catholic proselytism into the highlands of Tonkin, from the seminal influence of the 17th century Jesuits, via Bishop Puginier in the 1860s, to the end of the missionary presence in the highlands in the late 1940s. We will first follow a historical narrative to briefly review missionary as well as lay ethnographic texts produced until the 19th century on the upland ethnic groups. I should stress again the fact that I am presenting these lay authors here in order to establish what kind of ethnography of the northern Indochinese highlands was available at the time of the missionary installation in upper Tonkin. This should allow us, downstream, to gain an idea of the degree to which MEP members were acquainted - or not - with sources that could be found locally with relative ease. We will proceed next with the story of the foundation, growth, and decline of that MEP vicariate at the heart of this study, Upper Tonkin, with the aim of setting the political and ideological backdrop for the more detailed consideration of texts that unfolds in Part 4.

Since the early 1600s, Catholic missionaries from various denominations were present in Vietnam, although on a small scale and only in the lowlands. ${ }^{1}$ Near the end of that century, a papal intervention gave the evangelising task of the northeast portion of Tonkin - covering roughly one-third of it - to Spanish Dominicans based in Manila, whilst the Société des Missions Étrangères de Paris was given the remaining two-thirds. ${ }^{2}$ Until the curtain fell on French Indochina in 1954, the MEP was to remain the most important source of Catholic missionaries to Tonkin. Yet, despite this early start to Catholic proselytising, the mountainous areas at the periphery of the Red River delta remained untouched by

${ }^{1}$ Chappoulie, Henri. Rome et les missions d'Indochine au XVII siècle. Paris: Bloud et Gay, 1943.

${ }^{2}$ Guennou, Jean. Missions étrangères de Paris. Paris: Fayard, 1986.

(C) JEAN MICHAUD, 2007 | DOI 10.1163/9789047420217_006

This is an open access chapter distributed under the terms of the CC BY-NC-ND 4.o licenseMichaud - 978-90-47-42021-7 
European missionaries until late into the 19th century. Conversion was initially confined to the Kinh population in the delta - with the possible exception of some among the Muong minority, then still a fuzzy category used to designate an unspecified number of non-Kinh groups in the western foothills. ${ }^{3}$

Prior to the French military conquest of Indochina, reports were sent to France and Rome more or less regularly by a small number of missionaries who had succeeded in maintaining their presence in Tonkin, either openly or covertly. With no missionary outposts set up beyond the immediate periphery of the coastal areas and deltas, these reports and personal correspondences and diaries did not contain ethnographic material concerning the groups dwelling in the mountainous hinterland.

With his monumental Les missionnaires français au Tonkin et au Siam, XVII ${ }^{e}-X V I I I^{e}$ siècles [French Missionaries in Tonkin and Siam, 17th and 18th centuries] - his doctorat d'Etat - especially Volume Two devoted to Tonkin, historian Alain Forest has monitored the progress of French Catholic missionary work in Vietnam. He notes that in a clandestine fashion, often disguised as merchants, a few dedicated men from the MEP endeavoured for two centuries, starting in the 1660s, to spread the Word of God in 'Annam', hoping to be able to create the embryo of a local clergy. While their relationship with the local rulers saw ups and downs, Jesuits from Portugal and Dominicans from Portugal and Spain were also competitors to their project at times.

Dominican and Franciscan priests from southwestern Europe accompanied their countries' ships on voyages to Asia since the Renaissance. In the 16th century, some among them set foot in Tonkin on occasion, although none are known to have stayed for very long. In 1564, the Jesuits set up a base in Macau on the Chinese coast. Nearly a century later, from 1626, a few Jesuit missionaries - their total number estimated at 24 over 40 years - started to work in Tonkin. This was when their Japanese mission was closed and it was decided to redeploy those still embedded in Asia elsewhere. Among them, some French Jesuits visited the Vietnamese coast. The most famous French Jesuit representative to work in Vietnam before the 1660s was Father Alexandre

\footnotetext{
${ }^{3}$ Forest, Alain. Les missionnaires francais au Tonkin et au Siam (XVII $-X V I I I^{e}$ siècles). Analyse comparée d'un relatif succès et d'un échec total. Livre II-Histoires du Tonkin. Paris: L'Harmattan, 1998, 259-61.
} 
de Rhodes. He started his missionary work on the coast in Cua-bang in 1627. Jesuit preaching became so successful there that by 1639 it is estimated that 82500 Tonkinese had converted to Christianity. Local politics, however, obstructed further Jesuit activity and by 1663 nearly all their missionaries had been expelled from the northern kingdom by the Tring authorities.

To serve as a counterweight to the dynamic Portugal and Spain-based Catholic missionary expansion, of which the Jesuits were a spearhead, but also in line with the centralization of the administration of missionary work following the Trenta Council, in 1622 Pope Gregory XV created the Congregatio de Propaganda Fide, the Office for the Propagation of the Faith. This was operated by a permanent secretary and directed by 13 cardinals and two priests, with its headquarters in Rome. Thirty years later, it was to that Office and to Pope Alexander VII that Alexandre de Rhodes, back in Europe, directed his request to recruit more missionaries to send to Tonkin and Cochinchina, supported by his colleagues and future Bishops François Pallu and Pierre Lambert de La Motte. In Paris, the initiative was also supported by a number of influential people around the Compagnie du Saint-Sacrement who, at the time, were also promoting François de Montmorency de Laval as the first Bishop of Canada. King Louis XIV was eventually instrumental in the designation of all these Bishops and their promotion in Rome.

'Bishop', however, is not the correct word here. The system by which the Office nominated missionaries abroad where no formal organisation of the Roman Catholic Church had been erected before and where local authorities were reluctant to let such an installation occur, was to put a vicar apostolic, in fact a titular Bishop in partibus, at the head of former vicariates or new missionary territories. In the latter case, this action was the first step in establishing a local Christian community. This was done in the hope that future developments would be rewarding enough to eventually allow the erection of a full-fledged diocese headed by a formal Bishop. This last step would bring the new body into the Roman Catholic hierarchy under the authority of the Pope. This was the solution offered by Rome to Louis XIV in 1658 when officially, vicars apostolic, not bishops, were sent abroad from France to establish Catholic missions in Canada, China, Cochinchina and Tonkin.

So in 1658, François Pallu and Lambert de La Motte were made Bishops in partibus infidelium of Héliopolis and Bérythe respectively, and could thus, the following year, be made vicar apostolic for Tonkin and 
Cochinchina. ${ }^{4}$ The commission from the Office to the new vicars mentioned that they had to create an indigenous clergy, open schools and teach the Christian faith and Latin. In addition, they had to adapt to local customs as much as possible and avoid intervening unnecessarily in local politics. They also had to remember not to make any important decisions or name a new vicar apostolic without consultation with Rome and - more importantly for us - to regularly report in writing on their progress. ${ }^{5}$ Accompanied by several missionaries, these two vicars left France in 1660-1661 to eventually set up their Asian headquarters in Ayutthaya in Siam, where they were liberally welcomed at the time. It was only after several consultations with France and after elaborating a strategy of infiltration into their final destination that the first representative of the party, Father Chevreul, reached the Cochinchinese coast at Faifo in 1664. His arrival officially inaugurated three centuries of state-supported French missionary work in Indochina. Another representative, Father Deyder, was the first to arrive in Tonkin in 1666, disguised as a layman, three years after the last Jesuits had been forced to leave. He remained there until his death in 1693 after serving the last 14 years of his ministry as vicar apostolic of West Tonkin. In the meantime, Lambert de La Motte, representing Pallu who had returned to France on a diplomatic mission, had become the first vicar apostolic in Tonkin when he arrived in Thang Long (today Hanoi) in 1669.

Back in Paris, during this time, the Société des Missions étrangères de Paris was born. A seminary was founded in 1663 and recognised by the Pope the next year. This foundation immediately resulted in the formation of a missionary society to administrate the seminary.

In 1679 the Tonkin Vicariate experienced the first of a series of amputations when it was split in two parts, one in the west and one in the east, each under a different vicar apostolic. These two vicariates remained under MEP control although there was some rivalry between vicars from the MEP on the one side, and Jesuits as well as Dominicans on the other. In 1696, Rome changed its position and allocated the East Tonkin vicariate to the Spanish Dominican from the Philippines, represented by Bishop Lezzoli. From then on, that vicariate was to remain permanently out of the hands of the MEP. Further north in

${ }^{4}$ The third original vicar apostolic to Asia, Bishop Cotolendi, destined to set up a mission in China, died in India on his way to his ministry.

${ }^{5}$ Guennou, Missions étrangères de Paris, 74. 
the Southeast Asian massif, in adjacent territory under Chinese imperial rule, a MEP vicar was set up in Yunnan as early as the 1730s, and one was named to take charge of the Chinese provinces of Kouang-Tong (Guangdong) and Kouang-Si (Guangxi) in 1848, thus covering the northern and the eastern portions of the massif.

For most of the 18th century, the Catholic Vietnam missions had to live with the perils of travelling by sea from France, endure a disengagement of the motherland from Asia after the Siamese setback of 1688, and survive with insufficient recruitment in France and a general lack of financial means. In addition they had to skirt around the many shifts in Vietnamese politics and swings of mood towards the Christian religion, and handle the disturbances caused both by dissention within the MEP and by competition with other congregations that were locally active. Progress in the conversion of Tonkinese to the Christian faith was acceptable during periods of relative calm, only to experience critical setbacks during periods of adversity. From the arrival of Father Deydier in 1666 until the French Revolution in 1789, a total of 36 French missionaries affiliated to the MEP were stationed in Tonkin for periods ranging from little under six months, as for Lambert de La Motte and Bouchard in 1669-70, to nearly 50 years in the case of Bishop Néez between 1715 and 1764. Néez was also one of 20 missionaries who died in Tonkin in the same period. Never more than seven priests were present at any one time; all were stationed in the Red River delta close to coastal areas, more precisely in Pho-hien, Nghe-an/Thanh-hoa, Son-nam/Son-tay, and Ke-vinh. ${ }^{6}$ Clearly, no possible testimony on the populations of upland Tonkin was to be expected from such a small and geographically concentrated group of observers.

In 1790, a stretch of 25 years without support from France started thanks to the turmoil created by the French Revolution and the First Empire. Only four missionaries were left in Tonkin. The 1780 decade had also introduced a difficult period as it was the dawn of a dynastic change and a re-organisation of the political body that was to become modern Vietnam. The Lê dynasty was in its last years and the Nguyên dynasty was emerging in the person of Nguyên Anh, the future emperor Gia Long. Between 1792 and 1817, not a single missionary recruit could be sent from Paris. Ad hoc MEP recruitment in

\footnotetext{
${ }^{6}$ Forest, Les missionnaires francais au Tonkin et au Siam, 148, 183, 214-15.
} 
England and Italy yielded a meagre twelve new priests scattered over the whole of Asia. The Tonkin mission, like others in Asia, had to rely on the resources of the local clergy and temporary financial support from the Office in Rome.

Then, in 1822, after the MEP had recovered from this period, in order to solve the financial problems caused by the end of the era of royal patronage, it was decided to turn to popular support in France to finance the missionary work as well as the infrastructures. A new French national body was created, l'Oeuvre de la Propagation de la Foi, ${ }^{7}$ whose educational zeal to stimulate both human and financial commitment to missionary work overseas quickly established local branches in every diocese in the country. To whip up popular fervour and stimulate recruitment, an associated journal, les Annales de la Propagation de la Foi (Annals of the Propagation of the Faith) started being published the same year the Society was launched and was distributed to every parish in France (to which from 1868 onwards was added the additional weight of a weekly magazine, Les Missions catholiques). The former was often publicly read in church and quickly spread the stories and writings of missionaries abroad to many French households. It is certainly at this time and due to such literature that the first realisation came to the majority of the French that Siam, Cochinchina, Annam and Tonkin existed. This action without a doubt contributed to preparing the public opinion for the future colonial expansion in these areas, where many priests became martyrs in the decades that followed, a fate that was widely publicised and eventually served as an excuse to start the military invasion of Vietnam.

Between the moment Bishop Lambert de La Motte set sail for Vietnam in 1660 and the 1822 innovations directed at building a new financial basis for the missions, a total of 289 MEP missionaries had travelled to Asia. After the establishment of the Oeuvre de la Propagation de la Foi, this same figure was reached again within a much shorter time span of 30 years. In the next thirty years, 909 new MEP missionaries

${ }^{7}$ L'Oeuvre de la Propagation de la Foi, the Society for the Propagation of the Faith, was initially conceived of in 1819 in France by a devout woman, Pauline Jaricot, to support the MEP and its missionary work. When it was officially set up in 1822, its target had already been widened to include all missionary societies and all missionaries wherever they worked. Inspired by this model, a century later, the Vatican launched the Pontifical Mission Societies, under the Roman Curia, which centralised donations and redistributed them to over 1500 Catholic dioceses throughout the world. It continues to this day. 
were sent to Asia, a threefold increase. Then, between 1896 and 1900, in only five years immediately following the establishment of the UpperTonkin and Laos vicariates in 1895 and 1899 respectively, 336 missionaries were sent to ever more numerous Asian missions. This culminated with MEP having a total of 1420 active members in 1906, the record year in its whole history. Afterwards, numbers declined under the blows of an anticlerical Third Republic in France, two devastating World Wars, revolutions in Indochina and China, and the gradual public estrangement of the Church in the West. Overall, between 1815 and 1986, the year his book was published, MEP historian Jean Guennou calculated that a grand total of 4168 Catholic missionaries affiliated with his society joined missions. ${ }^{8}$

Back to the mid-19th century, in addition to the publicity orchestrated by Oeuvre de la Propagation de la Foi, several other factors help to explain the surge in recruitment numbers. First, both French missionaries and Vietnamese Christians, victims of religious persecutions between 1833 and 1859 under the three successors of Gia Long, were publicly awarded the status of martyrs back in France. This, as explained in Chapter 3, attracted considerable attention amongst the population and caused devout young men to step forward to partake in the glorious fate. As Guennou put it, during those decades, "the great recruiters for the missions were the martyrs. [...] Each time a missionary was slaughtered, ten volunteers came forward to take his place." ${ }^{9}$ Virtually all of the 172 MEP priests to be put to death during their apostolic mission in Asia were killed in the 19th century, a great many in Vietnam. Yet, the most important factor with regards to the ever increasing recruitment was probably the military invasion of Indochina from 1858, which allowed for easier physical and political access and called for more missionaries to carry the Catholic flag to the Orient. Seafaring was made easier in 1869 with the opening of the Suez Canal, with the appreciable consequence that fewer recruits would fail to reach their destination.

In the second half of the 19th century, the missionary presence, both in terms of numbers, as shown above, and geographical dispersion had expanded significantly. The MEP quickly found itself in charge of ever more numerous vicariates set up where and whenever the number of mission outposts and actual as well as potential converts

\footnotetext{
8 Guennou, Missions étrangères de Paris, 241-2.

9 Ibid., 242.
} 
justified it. In Tonkin, this time sequence reflected the specifics of the deployment of the colonial hold..$^{10}$ As mentioned earlier, the original Tonkin vicariate, created in 1660, had been divided in 1679 into West Tonkin under MEP responsibility, and East Tonkin attributed to the Spanish Dominicans. In the mid-19th century, West Tonkin was again considered too large to be comfortably administered from Hanoi and in 1846 was split from its southern portion. This became Tonkin Méridional (South Tonkin) while a diminished West Tonkin nevertheless still encompassed most of the western Red River delta including Hanoi, and, in theory, all of the mountainous areas between Laos to the west, and the right bank of the Clear River (Rivière Claire) to the East, where the Dominican domain started.

By 1880, for the French, Tonkin's northern and northwestern mountains were still an unknown domain that remained to be surveyed. It had not yet started to be an object of missionary activity. Yet, by the time the colonial 'pacification' of Protectorat du Tonkin was over in the mid-1890s, the West Tonkin vicariate was considered in need of being split again. Two new entities were chipped off the Hanoi-centred hub. These were Haut-Tonkin (Upper-Tonkin) in 1895, covering the high region from just north of Hanoi to the borders of China and Laos and, in 1901, Tonkin Maritime, which took over the southern coastal part.

In spite of this gradual breaking up of the hefty original 17th century Tonkin vicariate, the decentralization of missionary administration towards four secondary centres did not significantly undermine the political prevalence of Hanoi, the heart of Kinh society and the See of Catholic and colonial administration. Indeed, the vicar apostolic of a constantly shrinking West Tonkin vicariate invariably remained the 'first among equals' in the Protectorate's ecclesiastical hierarchy.

\section{The First MEP Publications from Upper-Tonkin}

The creation of the Upper-Tonkin vicariate in 1895 marked the start of active proselytizing in these mountainous areas. Before, severe unrest in the highland region caused by the threatening presence of runaway troops, freebooters and marauders from China had limited a missionary presence. Thus, only a handful of MEP priests had journeyed to one or

${ }_{10}$ This brief history on the constitution of vicariates in Tonkin is a synthesis of information found in various MEP archives, notably several yearly Comptes-rendus. 
another of the non-Kinh groups in the mountains north and northwest of the Red River delta. ${ }^{11}$ It is not very helpful to devote much time to their writings, which systematically lacked precise identification of the local people, tending to lump all non-Kinh into the broad category of 'tribus sauvages'.

The annual fournal de la mission du Tonkin later became known locally simply as fournal des missions, and later, Comptes-rendus. The pre-19th century issues of the fournal des missions yield useful insights into the mind sets of the authors who contributed to it, a mind set that was arguably similar to that of their colleagues who would later write on Upper-Tonkin. This journal was written in the form of a multi-voice narrative, composed of many quotations from letters of missionaries to their Bishop, linked together by a text produced by the official vicariate's editor. The facts that were presented were precisely located and the exact dates of events recorded. Yet these facts were visibly chosen to follow a particular agenda, or with the intention of making a specific point. Most of the time, the strategy was to make an impression on readers back in France with the intention of raising funds by stressing the hardships of missionary work while, in contrast, providing figures of the successful conversions obtained in any given mission. Often, such texts graphically described persecutions with the number of houses burnt or converts killed. Whenever a French missionary died violently in such clashes, the editor included an obituary on the deceased. Extremely useful from a historical point of view, these pre-conquest writings were however of little value as ethnographic text on highland populations.

On occasions, however, a pearl would appear. Such as when the Journal des missions included a rare story on a mission sent to non-Kinh populations. Before the end of the 19th century, such populations were always situated in the immediate vicinity of Kinh areas. For instance, in a letter dated July 3rd, 1789, ${ }^{12}$ author and missionary Le Roy tells his former missionary colleague Blandin about his visit to a then one-year old mission among the Muong of Lac-tho region. This area was less than a hundred kilometres south-west of Hanoi, thus within the limits of the (then) West Tonkin vicariate. Despite its proximity to a major urban and political centre, this region of moderate elevation standing

\footnotetext{
11 See for instance correspondence on early and short lived tentatives called Mission des sauvages in 1854 and 1881-83 narrated respectively in vol. 709 (nos. 90, 99, 100, 103, 112, 113, 114) and vol. 710 (nos. 2, 3, 4, 11, 21) at the MEP archives.

12 MEP Archives, vol. 962.
} 
between the delta and the valley of the river Ma was nevertheless very much on the margins of Kinh civilisation. A century later, in 1889, it was one of the areas still marked as inhabited by 'tribus sauvages' by religious historian Launay. At the time when Le Roy wrote to Blandin, there were apparently around one thousand converts among the Muong in this location thanks to the work of a Vietnamese priest, Father Hoa. Le Roy was sent to assess the progress of this remote community, nothing more. He noted that the region was rarely visited by Europeans as the roads were difficult, and reported that the customs of those he called montagnards, mountain dwellers, were totally different from those of the Kinh. In his letter he also described the form of local authority, assessing that winning the hearts of the local chiefs would be the surest way to be able to rule over these people. Additionally, he situated their cultural evolution at a level he called the Golden Age, and recorded the physical layout of villages, the house architecture, as well as making comments on marriage and funerals, religious beliefs, and cuisine. He glumly concluded that "Lac-tho region is not an attractive country and only charity and duty could attract missionaries there."13 What is of interest in such an account, in addition to the basic descriptions that can be used for comparative purposes, was information of a political nature. Le Roy tells us that these Muong spoke a language different from Vietnamese; they paid tribute in rice to the Kinh, and were sometimes enlisted to wage war on the side of the Kinh rulers, all information of historical and ethnographic value. Moreover, Le Roy revealed an aspect of the missionaries' persona in this location when he connected the appeal of mission outposts to the charm of the location, as opposed to selflessly conducting God's business wherever needed be. It seems men longing for martyrdom could also have preferences. Finally, Le Roy's letter itself did not contain any such words as 'savages' or 'tribe' but included instead the earliest mention of the generic word montagnards - not-capitalized - that I have found in relation to Tonkin, indicating the clustering of highland groups into a category, in this case an essentially descriptive one. ${ }^{14}$

Between 1650 and 1895, besides their general correspondence and their contributions to the official missionary media, some MEP mission-

\footnotetext{
${ }^{13}$ Ibid., 118, dated 1789.

14 The question as to whether Kinh missionaries could have written - in Vietnamese? French? Latin? - on their experiences and observations in non-Kinh areas, remains very much open, as is suggested by the fact that the Lac-tho mission among the Muong just mentioned was apparently managed by a resident Kinh priest.
} 
aries also published additional work relating to one aspect or another of the cultures of Tonkin. It would be beyond the scope of this book to name them all, so I will simply list a sample of these writings. ${ }^{15}$

At this stage in our exposé, one should not be surprised that the most prominent focus of published scholarship by missionaries in Indochina was indigenous languages. Not so much linguistic studies proper, which would have required appropriate intellectual education, but a utilitarian production of glossaries, dictionaries, and grammatical studies instrumental to the successful conversion of the Annamites. These included such tools as those produced by De Rhodes (1651), Jourdain (1872), Theurel (1877), Ravier (1880), Dourisboure (1889), or Bon and Dronet (1889). Travelogues as well as personal life stories and accounts of day to day existence in the missions were also in demand, especially in the popular religious publications as we will see in Chapter 7. Some scholarly works on Indochina history were also produced and some ecclesiastics also published personal observations on geography, culture and politics. Biographies of prominent MEP colleagues with substantial information on their lives and the milieu where they worked were commissioned for future generations to emulate, such as those by Louvet and Monteuuis. ${ }^{16}$

In addition, a handful of individual missionaries' contributions extended into the specific field of highland ethnography. Pierre-Jacques Lemonnier de La Bissachère became a member of the MEP in 1789, boarded a ship to his mission the following year, and spent 17 years in Tonkin before returning to France in 1805. Over the troubled years

${ }^{15}$ Some of these works have not been included in the bibliography. More detailed information on these can be found at the entry 'Société des missions' in Antoine Brebion's Dictionnaire de bio-bibliographie générale, ancienne et moderne, de l'Indochine francaise. Annales de l'Académie des Sciences coloniales, Vol. VIII. Paris: Société d'éditions géographiques, maritimes et coloniales, 1935, 354-97.

${ }^{16}$ De Rhodes, Alexandre. Le catéchisme en langue vietnamienne romanisée, 1651. Roma, Université Grégorienne, 1956-1957; Jourdain, Denis. Grammaire franco-annamite. Saigon: Imprimerie du Gouvernement, 1872; Theurel, Joseph (Bishop). Dictionarium anamiticalatinum, Ex opere ill. et Rev. Taberd constans; necnon ab ill. et Rev. F.S. Theurel. Ninh phu: Imprimerie des Missions du Tonkin occidental, 1877; Ravier, Marcel Henri. Dictionarium latino-anamiticum completum et novo ordine dispositum, Ninh-phu: Imprimerie des Missions du Tonkin occidental, 1880; Dourisboure, Pierre. Dictionnaire Bahnar-Français. Hong Kong: Imprimerie des Missions étrangères, 1889; Bon, Henri and J.B. Dronet. Manuel de conversation franco-tonkinois. Késo: Imprimerie de la Mission, 1889. Examples include: De Rhodes, Alexandre. Tonquinensis historiae libri dvo (...), Lyon: K.B. Denvenet, 1652; Launay, Adrien. Histoire ancienne et moderne de l'Annam, Paris: Challamel,1884; Louvet, Louis Eugène. Vie de Mgr Puginier, Évèque de Mauricastre, Vicaire Apostolique du Tonkin Occidental. Hanoi: Schneider, 1894; Monteuuis, Gustave. L'âme d'un missionnaire. Vie du P. Nempon, missionnaire apostolique du Tonkin Occidental. Paris: Victor Retaux et Fils, 1895. 
of the succession wars, La Bissachère spent long periods of time in hiding until the 1802 installation of Gia Long on the throne of unified Vietnam. Then came the normalisation of relations between Christian missionaries and the State, a direct consequence of the debt of honour the Emperor had agreed upon for the support provided to him by Bishop Pigneau de Behaine. In 1802, La Bissachère and his Bishop, Jean-Jacques Guérard, were made mandarins by Gia Long. This allowed the missionary to exercise his ministry and collect his observations freely. Once back in France, La Bissachère published two substantial books, one in 1811, the other in 1818, in which he drew a portrait of Indochina as it was known at the time, focusing on the high culture of the coastal areas and the deltas. Incidently, part of his books dealt with the same Lac-tho area and its Muong population mentioned above, supplying general observations, some ethnographic details, and historical interpretations on the origin of the Muong and of their relationships with the Kinh.

Later in the 19th century, missionary activity developed in the remoter areas. The Central Highlands were starting to be proselytized, leading to interesting contributions by missionaries Pierre Dourisboure and Jean-Baptiste Guerlach. In the north, Pierre-Charles Pinabel, who died in 1885 at age 41 after 15 years in Tonkin, published his Notes sur quelques peuplades sauvages dépendant du Tong-King in which he described the Chau-laos, a portion of western Tonkin on the Laotian border where he had worked for five years. This was also the time when his colleague, Léon Girod, whose work will be examined in the next chapter, started visiting Upper-Tonkin proper, kick-starting a steady stream of published observations on the highland populations there. ${ }^{17}$

\section{Publications by 19th Century Explorers, Diplomats and Military Observers}

In the preceding chapter it was established that missionaries did not operate alone. Individually as well as collectively, they were very much

17 Dourisboure, Pierre. Les sauvages Ba-hnars, Cochinchine orientale. Lyon, Lecoffre, 1875; Guerlach, Jean. "Moeurs et superstitions des Bahnars. Journal de voyage de M. Guerlach." Les Missions catholiques, vol. 19, pp. 441-527, 1887; Pinabel, PierreCharles. "Notes sur quelques peuplades sauvages dépendant du Tong-King." Bulletin de la société de Géographie de Paris, 7érie, vol. 5, pp. 417-33, 1884. 
part and parcel of the colonial apparatus that favoured their proliferation in Indochina and each missionary was unavoidably embedded in this colonial ideology. What is more, publications on upland Indochina by lay fellow Frenchmen presumably also had an impact on the missionaries' perceptions of the local space and peoples. At the time that the Upper-Tonkin vicariate was set up in 1895, a number of such works had already been made available. Some among the most prominent ones are reviewed in this section because of the role they then played in influencing the writings of all Europeans to follow.

From the 1860s, during the two decades before the French colonial army took control of the northern highlands, a few Frenchmen had ventured through the Vietnamese portion of the Southeast Asian massif. Some of the documents left by these early travellers contain variously elaborated observations of, and more or less educated opinions on, the indigenous populations encountered on their journeys. As a rule, these early travellers were pursuing political or economic objectives and only noticed in passing, as it were, the local populations.

It is not necessary to devote a lot of time to publications by early discovery teams such as the Ernest Doudart de Lagrée and Francis Garnier expedition up the Mekong in 1866-68, or individual ventures such as merchant Jean Dupuis and his explorations of the Red River around the same period. These contributions to the genesis of colonial French Indochina were indeed considerable, but their legacy in terms of ethnography, minor. ${ }^{18}$ Well aware of the particular interests of their readership, their portrayal of 'primitive' peoples only amounted to succinct mentions. These were calibrated along the principle that the smaller the military capacity and economic significance of a given group, the briefer the account should be. At best, such as in the Doudart de Lagrée and Garnier case, some 'primitives' were judged exotic enough to be depicted, artificially striking a pose and grouped in an improbable assembly, on plates for the Album pittoresque (the Picturesque Album)

18 Cf. Osborne, Milton. River Road to China. The Mekong River Expedition, 1866-73. London: Allen and Unwin, 1975. This is not to mean that these individuals were not scholarly in one way or another. Garnier did publish some ethnographic accounts and suggested some interesting historical connections between groups (1873b: 329ss). Dupuis spoke Mandarin, was a member of the Société académique indo-chinoise de Paris and published on political events and trade in Tonkin (Dupuis, Jean. L'ouverture du Fleuve Rouge au commerce et les événements du Tong-Kin, 1872-1873. Journal de voyage et d'expédition de J. Dupuis, 1879). 
forming the first part of the Atlas du voyage d'exploration en Indo-Chine, an approach resolutely reminiscent of the naturalist sketching plants and animals for his records. ${ }^{19}$

At about the same time, in this case in the late 1860s, Emile Rocher, an administrator for the French China Customs (l'Administration des douanes impériales de Chine), travelled from Tonkin to Yunnan. He did so as a member of a diplomatic mission launched in the wake of the recent agreement made with the Yunnan authorities aimed at providing local rulers with the Western weaponry they needed to crush the Muslim uprising (also known as the Panthai Rebellion) that raged in the region from 1855 to 1872 . Rocher published his account of that visit in two books in 1879 and 1880. To my knowledge, these constitute the first French language published accounts on the high region that included a section devoted specifically to the ethnography of highland societies, which makes this document worth looking at.

Facing important delays in the delivery of artillery pieces to Yunnan-sen (today Kunming), Rocher kept himself busy with investigating the mineral resources of the region. Over a period of two-and-a-half years, thanks to the travel documents granted to him as an official guest of local authorities, he was able to visit numerous remote areas around the Yunnanese capital and gather the data he needed to write his books. These books were designed for administrative consumption, with the aim of informing on the topography, the layout of roads, the communication systems, the regional history, the current rebellions, production and commerce, and in particular, indigenous metallurgy. Over a total of 500 pages, a modest but significant 26 pages are specifically devoted to a description of the tribus indigènes. While Rocher, in his capacity as the official envoy to Yunnan, was rather bold in his account of Yunnan in general, Rocher the ethnographer was more prudent. He declared:

The vast area from the point of view of races is indeed among the most interesting ones and would require special knowledge; true to our role as an impartial witness, we reproduced what we could learn, leaving to more scholarly persons the care to speak on these matters in an authoritative way. ${ }^{20}$

${ }^{19}$ Garnier, Francis. Album pittoresque, first part of Atlas du voyage d'exploration en Indo-Chine. Paris: Librairie Hachette, 1873a.

${ }^{20}$ Rocher, Émile. La Province chinoise du Yün-Nan. Tome 1, Paris: Ernest Leroux, 1879, xiii. 
Why, one might ask, was such a cultural section necessary to an inventory on the riches of Yunnan written to the attention of the colonial administration? The author certainly had a strategic purpose in mind when he wrote that all the non-Han groups which he encountered were fiercely opposed to assimilation by the Chinese. This, indeed, made them potential allies for a conquest operation, should the French authorities wish to launch one from Tonkin. As a writer, Rocher was also aware of the particular interests of his readership in France, and he undoubtedly wanted to entertain them with accounts of exotic races and customs. As many authors before him eloquently showed, this sort of intention can lead to the best, and the worst. Overall, Rocher does comparatively well. Though data was obtained through interpreters, it was still a first hand account in the field. In terms of configuration, this section was given a loose structure and touched on a number of topics in varying proportions depending on the group: history, geography, physiology, material culture, agriculture and trade, relations with Han Chinese, character, marriage, and family. Some sweeping statements such as 'ils ne connaissent aucune religion, ${ }^{21}$ they know no religion, certainly highlighted the author's unawareness. A dreamy standpoint also drove the Frenchman to adopt a semi-poetic, gender-biased style when describing Lo-lo women, revealed in particular by a concern with assessing exactly the degree of appeal these representatives of the sexe faible could reach on his personal scale.

Finally, Rocher used no methodological tools beyond observation and interviewing a random selection of people and taking notes. His account is weak on the empirical front; for instance, no indication is given of the demographic importance of any of the groups he presents and discusses nor are the location of places named in the text. The exact duration of fieldtrips, number of informants talked to, number of visits to such informants, and the exact circumstances in which the interviews were held, are all lacking. He divides the non-Han population of Yunnan between the Miao-tzu, Man-tzu, Lo-lo, and "an array of tribes without much importance." ${ }^{\prime 22}$ One is left without an explanation regarding the logic of these categories, while half of the 26-page ethnographic text is devoted to the Lo-lo alone.

21 Ibid., 24.

22 Rocher, Émile. La Province chinoise du Yün-Nan. Tome 2, Paris: Ernest Leroux, $1880,25$. 
Contemporaneous to the Rocher books, Marquis D'Hervey de StDenys, Chinese language professor at Collège de France, published in 1883 Ethnographie des peuples étrangers à la Chine, which was in fact a translation into French of a series of Chinese texts devoted to the non-Han peoples on the southwestern Marches of the Middle Empire. ${ }^{23}$ These had been written in the 13th century by Chinese administrator Ma Touan Lin. Properly speaking, Ma's text did not include ethnography and in this sense, de St-Denys' book derived all its information, be it the original Chinese text or the numerous footnotes that de St-Denys added, from second or third-hand sources, if not plainly from tales, gossip and hearsay. However, it has been widely read by subsequent observers and ethnographers, and in its position as one of the most ancient known accounts of the peoples in the Southeast Asian massif available in French, has been used repeatedly by French scholars thereafter.

Into a similar category falls the work of another fellow sinologist, diplomat Gabriel Devéria, who spent nearly twenty years on official postings in China between 1863 and 1882 before returning to Paris and eventually taking up a position at École des langues orientales vivantes. From his work on Chinese texts conducted from Paris, Devéria published in 1886 La frontière sino-annamite, description géographique et ethnographique d'après les documents officiels chinois, an account which, as its title indicates, made use of official Chinese written sources. Despite his lack of real first-hand knowledge of the peoples whom he touched upon in this document, Devéria's publication nevertheless influenced several of his successors in Asia, starting with MEP missionary Paul Vial who considered him to be the authoritative source on the political history of non-Han people in Yunnan. ${ }^{24}$

On the french Indochina side, medical doctor and diplomat FrançoisJules Harmand, a companion of military officer Francis Garnier during the 1873 military operations in Tonkin, and who became France's top man in Hanoi for a few months in 1883, published extensively on Indochina with regards to a number of fields. With a medical background, many of his papers present a strong leaning towards what today is called physical anthropology - biometrics, etc. Most of his papers are on Kinh

${ }^{23} \mathrm{Ma}$ Touan Lin. Ethnographie des peuples étrangers à la Chine, texte du XIII siècle traduit du chinois et annoté par le Marquis d'Hervey de Saint-Denys. Paris: Ernest Leroux, 1883.

${ }^{24}$ Devéria, Gabriel. La frontière sino-annamite, description géographique et ethnographique d'après les documents officiels chinois. Paris: Publications de l'École des Langues orientales, tome 1, 1886. 
culture, except for a few among the southern Central Highlanders. Out of his more than fifty publications, only a handful, including his 1912 De l'état de l'ethnographie indochinoise, hold interest, though moderate, for one studying the northern highlands. ${ }^{25}$

In the category of expedition literature addressing the northern Vietnamese uplands, one body strongly stands out, that of the publications derived from the Pavie Mission to Indochina which unfolded intermittently for 16 years from 1879 to 1895. Auguste Pavie, a Breton with a well-to-do family background, was a civil servant turned diplomat. His imprint on Indochina is of historic importance, not least because he was influential in the annexation of Laos to the French domain. He also paved the way for the pacification of northwest Tonkin thanks to an alliance with White Tai leader Deo Van Tri. He conducted a vast exploration of the mountainous regions on the fringes of the French colonial domain, directly contributing to claiming territory and defining borders with Siam, China, and British upper Burma. However, it was the scientific dimension of the venture, the Mission Pavie, which was to make him famous.

Officially, Pavie and his team were commissioned to go on a political reconnaissance representing France as part of a multi-lateral international border delimitation team along with the British and the Chinese. In spite of the clearly political nature of the project, valuable contributions to the ethnography of highland societies found their way into the official prose. In this regard, and unlike so many other contemporaneous ventures, it is of particular interest that the Pavie Mission was primarily composed of scholars and educated officers. Accordingly, its documents incorporated infinite details on itineraries (including maps), places visited, practicalities of the journeys, significant people met, the content of discussions with local leaders, estimations of the economic and political potential of allies, and a general political and strategic reflection. Such a fertile combination is a rarity. This explains in part why the Pavie Mission, being a reconnaissance trip to detail economic and strategic resources, has remained the richest single French contribution to the exploration of remote frontier territories and little known highland groups of Indochina.

${ }^{25}$ Harmand, Jules. "De l'état de l'ethnographie indochinoise." Revue d'etudes ethnographiques et sociologiques 4, 1912. 
These years under Pavie's overall leadership involved a number of separate sub-missions headed by several of his collaborators. They resulted in ten volumes published in France between 1898 and $1903 .{ }^{26}$ The substance of the seven volumes forming the Géographie et voyages series, the most interesting series from an ethnographical point of view, was based on daily notes taken during trips by collaborators of Pavie, or even Pavie himself when he happened to be part of the expedition.

For anthropologists of the highlands, the two most interesting books of the Pavie Mission are Captain Pierre-Paul Cupet's Voyages au Laos et dans les régions sauvages du sud-est de l'Indo-Chine [Voyages in Laos and the savage regions of southeastern Indo-China] (1900), and Voyages dans le Haut-Laos et sur les frontières de Chine et de Birmanie [Voyages in Upper Laos and on the borders of China and Burma] by Pierre LefèvrePontalis (1902). Captain Cupet's book focused on non-Kinh societies in the Central Highlands of Vietnam. As important as his text is for the ethnography of highlanders in that area, it is not related to the northern situation and will not be further commented upon here. With Lefèvre-Pontalis' Voyages on the other hand, we are touching the core of the social space interesting this book. So who was Pierre LefèvrePontalis, and what did he write that was to prove so interesting? ${ }^{27}$

Pierre Lefèvre-Pontalis was born and raised in an aristocratic family with his father being, in Pavie's own words, 'one of France's considerable personalities'. While still studying to become a diplomat, Lefèvre-Pontalis lobbied actively to approach Pavie in the hope that he would be per-

26 These are: I-Mission Pavie en Indochine. Etudes diverses. 3 volumes. Vol. 1: Recherche sur la littérature du Cambodge, du Laos et du Siam (Pavie); Vol. 2: Recherches sur l'histoire de ces mêmes pays, contenant la transcription et la traduction des inscriptions par M. Schmitt (Pavie); Vol. 3: Recherches sur l'histoire naturelle de l'Indo-Chine (Pavie). II-Mission Pavie. Géographie et voyages. 7 volumes. Vol. 1: Exposé des travaux de la mission (introduction première et deuxième périodes) (Pavie); Vol. 2: Exposé des travaux de la mission (troisième et quatrième périodes) (Pavie); Vol. 3: Voyage au Laos et dans les régions sauvages du sud et de l'Indochine. (Capitaine Cupet); Vol. 4: Voyage au Laos et dans les régions sauvages de l'est de l'Indochine (Capitaines Malglaive \& Rivière); Vol. 5: Voyage dans le Haut-Laos et sur les frontières de Chine et de Birmanie (Lefèvre-Pontalis); Vol. 6: Passage du Mékhong au Tonkin. (Pavie); Vol. 7: Récits de voyage (Pavie).

${ }_{27}$ Cupet, Pierre-Paul (Capitaine). Voyages au Laos et chez les sauvages du sud-est de l'IndoChine. Vol. 3 of Mission Pavie - Géographie et voyages, Paris: Ernest Leroux, 1900; Lefèvre-Pontalis, Pierre. Voyage dans le Haut-Laos et sur les frontières de Chine et de Birmanie. Introduction by Auguste Pavie. Volume 5 of the Géographie et voyages section of Mission Pavie Indo-Chine 1879-1895, Paris: Ernest Leroux, 1902. Prior to its appearance as a book, two earlier compilations of Lefèvre-Pontalis' observations of an ethnographic nature had been published in fournal asiatique (1892; 1896). 
mitted to join Pavie's Mission in Indochina. The two men first met in Paris in 1885 several years after the Mission had started. Lefèvre-Pontalis had obtained a degree in Vietnamese and Malay languages from École des langues orientales quickly followed by another degree in Law. Pavie saw the value of this recruit and arranged for him to be attached to the Ministry of Foreign Affairs. With his mentor's support combined with additional powerful patronage, the young diplomat was sent to Indochina in 1889 to join the Mission. He became Pavie's personal secretary and followed him for a year from Bangkok to Phnom Penh, Saigon, Hanoi and Luang Phrabang, receiving first-hand, on-location teaching on Asian-style diplomacy.

Pavie also included in this apprenticeship deeds akin to the work of an ethnographer. In his mind, this appears to have fitted the category of 'distractions':

Captivating as the Mission's work may be, I [Pavie] would soon show him [Lefèvre-Pontalis] that it also allows for distractions, for useful pass-times the voyager must seek: that walking on paths or near creeks bordered with luxurious vegetation presents to the traveller's eyes elements for the most interesting of natural histories; that one can, without even slowing down as it were, collect curious plants, shells and shiny insects; that the caravan's indigenes are skilled in catching, dead or alive, birds, fish, and small animals of all kinds; that there is no better way to make pleasant and fruitful the rest periods and the evenings spent in villages inhabited by peoples of all origins than to carry out, by interrogating the elders, research started by our predecessors and which can be, for a long time ahead, productive in terms of documents on the past, mores, customs, languages and folklore. [...] All these occupations I undertook myself with pleasure and was happy to introduce to him in turn. ${ }^{28}$

Promoted to head of sub-missions, Lefèvre-Pontalis had the opportunity to explore upper Tonkin, upper northern Laos, and southern Yunnan over two trips separated by two years. His specific commission for these journeys was to map the periphery of the French colonial domain, make contact with local leaders, and conceive of a strategic use for the populations and places visited. He was also to target good economic potentials, and imagine the possible organisation of trade networks that could root and support the profitable expansion of French commerce on these frontiers. ${ }^{29}$

\footnotetext{
28 Pavie, in Lefèvre-Pontalis, Voyage dans le Haut-Laos, xxxvi-vii.

29 This would in time include the production and trade of salt, silk, cotton, beeswax,
} 
The first, briefer trip unfolded from April to June 1891; the second lasted ten months from June 1894 to March 1895. Lefèvre-Pontalis' trips were made in the company and under the guidance of Deo Van Tri, the White Tai leader of the Sip Song Chau Tai, his family's feudal domain in the upper basin of the Black River in Tonkin. This established jurisdiction had been recognised by France in a treaty signed on a visit by Pavie in April 1889 which resulted in the political and military submission of the Deo family to the French colonial authority, bringing an end to the staunch armed opposition by the Tai ongoing since the colonials had first set foot in Tonkin in 1873.

With Deo Van Tri and his men, Lefèvre-Pontalis visited most of the main valleys of upper northern Laos, parts of the Tai Lue domain of Sip Song Phan $\mathrm{Na}$ in southern Yunnan, a section of eastern Burma on the right bank of the Mekong river, and nearly all of the Sip Song Chau Tai stronghold in Tonkin. He also navigated the Black River up and down to Hanoi several times. The diplomat went up the Mekong to check the application of the 1893 border treaty with Siam and to explore the Nam Ta River, its population and resources. He joined the multilateral commission in charge of setting the borders separating China from French Indochina between the Mekong and the Red River, and the Anglo-French border commission in western Laos set up to draw a mutually agreeable limit between the two colonial domains at the only point in the Far East where they actually touched. One can see without difficulty that with such an extensive coverage of the southern Southeast Asian massif coupled with language skills and in situ training, Lefèvre-Pontalis became the most significant French ethnographer of that era on the northern highlands of Indochina.

Two-thirds of his writings in Voyages dans le Haut-Laos et sur les frontières de Chine et de Birmanie relate to his second trip. This is in a way unfortunate. On his second journey, it is a more mature diplomat who revealed himself, one who had gained in experience, confidence and authority, busier than before with the promotion of France's interests among the local population. He held audiences, reprimanded local leaders, delivered passports, and saw to the enforcement of treaties. He encouraged the consolidation of existing trade networks and marketplaces that were

and tea, to which he later devoted articles. Lefèvre-Pontalis, Pierre. "Notes sur quelques populations du nord de l'Indo-Chine (lère série)." Extrait du Fournal asiatique, Paris: Ernest Leroux, 1892, 41-2, 57-69. 
of interest to France's political and economic ambitions in the region. In the evenings, around the fire, the little time left that could have been used for the "useful pass-time" of interrogating elders, was spent instead on strategic discussions with fellow Frenchmen and local allies. In this second trip, Lefèvre-Pontalis had come as the political arm of the conqueror, and he intended to leave those encountering him in no doubt about it. As a consequence, the space given to the description of the highlanders and their societies shrunk markedly from the first trip, leaving less to ponder in terms of interesting ethnography. Focused on the people whose authority had to be tamed, clipped, or won to the colonial cause, Lefèvre-Pontalis forgot about the unimportant people carrying little political weight.

The ethnographic material Voyages contains is thus of uneven value. For most of the book, it is mingled with a prolific prose. Provided that enough energy is devoted to the task, the reader can extract facts about, and learn valuable information on, the inhabitants of the mountainous area, in particular on the complex political situation linking together, or pitching against each other the many local groups. The same applies to the relationships between local groups and the regional powers in the surrounding mid- and lowlands.

A decisive factor that helped Lefèvre-Pontalis to nevertheless competently conduct first-hand observations of highland commerce and politics was the presence in his caravan of Deo Van Tri and his men. With a legacy built from years of Tai feudalism, tough politics, and occasional banditry that Deo's family took part in around these mountains, the White Tai had long been a force to be reckoned with on regional trade circuits. Of course, the trip publicly displayed the commitment to the French cause of Deo Van Tri, which was certainly Pavie's strategic goal. Yet, it was also a golden opportunity for the White Tai leader to visit distant trade partners in prestigious and powerful company and make progress on ancient deals, renew alliances, and secure new ones in less familiar areas visited by the expedition in this time of fresh peace. Lefèvre-Pontalis tells us that verywhere the French-Tai caravan went, the White Tai chief was feared and respected.

Lefèvre-Pontalis paid a great deal of attention to these encounters, eager as he was to understand local politics and a history that the French were still discovering. He liked to take part in the discussions held by Deo Van Tri and his trade partners. From this vantage point, he could ascertain the layout of regional power relations. He could for instance tell that the relationship between the White Tai and the 
other Tai-speaking groups in the region, in particular the Lao, Shan, Youne and Lue, was generally good enough to partake in common and profitable trade networks. These networks, in particular, were regarding an all-important merchandise, salt, brought from the Delta through regular river convoys on the Black River. He learned about ancient alliances and feuds that could have an impact on the enforcement of colonial rule. He mentioned that the Black Tai, whose territory was centred on the Dien Bien Phu plateau and the middle Black River valley, were loathed by the White Tai who considered the former to be stupid and cowardly. ${ }^{30}$ Around Muong Sing in upper Laos, the Tai Youne resented their northern cousins the Lue, who had invaded them on many occasions and were still posing a threat in the late 19th century. In Xieng Khong on the Mekong, the Youne paid tribute to the Nan principality for fear of military exactions they had often endured before, and this tributary relationship infuriated the Lao of Luang Phrabang who claimed lordship over Xieng Khong. As for the non-Tai groups, Lefèvre-Pontalis consistently depicted them as clients of one or several nearby Tai groups who had long used them as coolies (he names the Asong, Ounhi and Lolo), farmers (the Yao, Meo, Lolo), trade partners, or providers of food when a caravan crossed a village. ${ }^{31}$ Reading Voyages, one is actually left with the lasting sense that the non-Tai highland groups had little else in common with each other than to live in the upland jungle in precariousness and poverty, and that they existed in a state of economic and political dependency, even exploitation, by the feudal Tai groups. ${ }^{32}$ Lefèvre-Pontalis noted that these non-Tai highland groups were on a course of irreversible linguistic and cultural assimilation to the Tai, and the lower geographically the location of their villages, the faster the pace. Such examples, and many more contained in Voyages, offer a unique window onto the social relationships of power and commerce amongst Tai principalities in the mountains of the Peninsula.

\footnotetext{
${ }^{30}$ Incidentally, proof of this long term inimity continued to be found until the time of the Dien Bien Phu campaign of 1953-54. Cf. McAlister, John T., Jr. "Mountain Minorities and the Viet Minh: A Key to the Indochina War." In Southeast Asian Tribes, Minorities, and Nations, ed. Peter Kunstadter. Princeton: Princeton University Press, 1967; Michaud, Jean. "The Montagnards in Northern Vietnam from 1802 to 1975. A Historical Overview from Exogenous Sources.” Ethnohistory, vol. 47, no. 2, 2000.

${ }^{31}$ Lefèvre-Pontalis, Voyage dans le Haut-Laos, Chapter IV, 'Chez les Khas Kouen', and chapter X, 'Chez les Mou-Seu'.

32 "In the end, it is the eternal question of the Thai exploiting the Kha and trying to appropriate their labour at the cheapest cost." Ibid., 286.
} 
All things considered, one is led to think, reading Voyages, that, assuming Lefèvre-Pontalis was genuinely interested in conducting ethnography, the tone that he used in his accounts certainly has him fit nicely with what George W. Stocking Jr. called the benevolent colonial administrative despot as ethnographer. Still, our man was a rare breed. Of all the forty or so French officers, diplomats, administrators, physicians and other scholars who joined the Pavie Mission over its 16 year life, Lefèvre-Pontalis is the only one who published independent pieces devoted specifically to the ethnography of the peoples living in the remote regions that were visited. ${ }^{33}$ Why did he endeavour to write and publish this? Did he conceive of himself as being particularly well equipped to deal with issues such as language, taxonomy, culture and history of exotic peoples? Perhaps not. In a time when French professional anthropology was still a few decades away, a task involving fieldwork in the remotest possible locations an educated European could conceive of, was of immense appeal to whoever fancied the intellectual challenge. Lefèvre-Pontalis was simply a suitably prepared man finding himself in the right place at the right time. He had studied Vietnamese and Malay languages, true, though hardly any highland language. ${ }^{34}$ In terms of his acquaintance with the relevant literature of the time, he mentions that when preparing for his missions in Paris, he had read Alexander Colquhoun and British administrator Lord Lamington, and was familiar with the published works of fellow French explorers and officials such as Doudart de Lagrée and Garnier, Henri Mouhot, and medical doctors Harmand and Paul-Marie Néis. Later, he read dozens of additional authors to underpin his analysis in further publications. This may be just about the best that can be expected from a non-professional anthropologist at a time when direct experience of ethnographic techniques was by and large the only way to learn the trade.

${ }^{33}$ In addition to Voyages, he published in the fournal asiatique and T'oung Pao respectively the two "Notes sur quelques populations du nord de l'Indo-Chine" (1892 and 1896 mentioned above), and two papers on "L'invasion Thaïe en Indochine", (1897 and 1909). He also published a volume titled Populations du Nord de l'Indochine (n/a) and a few pamphlets on the Kha and the Youne. It would be fair, however, to also acknowledge attempts by two other fellow members of the Pavie Mission, one by Joseph Vacle in his input to volume Two of the Mission's Géographie et Voyages series; and, in addition to a participation in volume 4, one by Capitaine Armand-Joseph Rivière: "Notes sur les Méos et sur le commerce du Mékong" published in 1893-94 in Annales de Géographie.

${ }^{34}$ On his first trip, any form of Tai, for instance, was by and large alien to him. He confessed conferring with Deo Van Tri using some composite tongue mixing hand signs, Vietnamese, French and only a few words of Tai. 
And finally for this chapter, at about the same time as Pavie and Lefèvre-Pontalis were on their first joint journey in Indochina, it is not superfluous to mention a French aristocrat who followed in Pavie's footsteps of 1888 along the Black River, the Nam Ou, and the Mekong River, and went on to explore western Yunnan and Assam. Prince Henri-Philippe-Marie d'Orléans, directly related to the heir to the throne of France, not being able to find a comfortable place there under the Republic, had been refused the possibility of a high-flying career in the French military and turned to less orthodox means to prove himself. He published extensively on his travels through Indochina and has been credited with 'discovering' the sources of the Irrawaddy River. What he left in terms of ethnography of the peoples he met during his journey, notably in an account published in 1894, amounts to some reasonably well informed discussions on similarities in vocabulary between different groups. To Hmong specialists, one attractive contribution of his venture was the fact that he reported having met no representative of the Miao-tze - today's Miao and Hmong - on his journey. This supports the hypothesis that that group had not, at least at that time, yet used the route through western Yunnan to eventually enter Burma and Thailand. ${ }^{35}$

Having completed this short survey of secular authors, it is now time to meet missionary authors and enter the specific history of missionary expansion in highland Tonkin as well as the particular history of the Upper Tonkin MEP vicariate. As such, this will go a long way in revealing the administrative and, arguably, intellectual space within which the conceiving of upland cultures and identities took place.

35 D’Orléans, Prince Henri-Philippe-Marie. Autour du Tonkin. Paris: Calmann-Lévy, 1894. 


\section{CHAPTER SIX}

\section{MISSIONARY COLONIAL EXPANSION AND THE UPPER TONKIN VICARIATE}

Practically all the authors discussed in this chapter are missionaries. ${ }^{1}$ Only on occasion will a voice from the colonial administration - men again - be heard. This account, therefore, does not attempt to cover the full range of the colonial politics of missionary expansion in Tonkin, which would require many more voices to be inserted in the narrative and, in any case, it is the work of historians. ${ }^{2}$ Here, we will attach ourselves to the missionary side of the story. A good deal of attention will be paid to identifying individual missionaries, their intellectual itineraries (whenever possible), their exact postings, the course of their actions, and as much as possible, their mind sets when they wrote. Providing such details is needed for a number of reasons as were exposed earlier in this book, including being able to link the texts of these missionaries with specific local populations and with the texts of other colonial agents of that period.

In the narrative that is about to unfold, we will first meet the dominant figure of missionary Tonkin at the end of the 19th century, Bishop Paul Puginier (1835-1892), and consider his seminal influence in the establishment and the expansion of the Upper-Tonkin vicariate, a phase that lasted from 1895 to about 1920. Then, we will see that a lull in missionary activity preceded a slow decline, leading to the final termination of most missionary activity in the first years of the First Indochina War (1946-1954). Indeed, the Upper-Tonkin vicariate rose and fell within half a century.

1 This chapter is based in part on my article "French Missionary Expansion in Colonial Upper-Tonkin." Journal of Southeast Asian Studies, vol. 35, no. 2, pp. 287-310, 2004a, reproduced here with the Journal's kind permission and with alterations to adapt to the needs of this book.

${ }^{2}$ See Lê, Nicole-Dominique, Les Missions-Étrangères et la pénétration française au VietNam. Paris: Mouton, 1975. 


\section{Missions and the Colonial Projegt in Tonkin}

Acknowledging the importance of contextualising missionary expansion within the political extension of a colonial power, we need to outline the political foundations of missionary deployment in the upper region of Tonkin. Historian Cao Huy Thuần has discussed the successive stages of missionary collaboration in the colonial takeover, showing how churchmen even contributed to guiding this takeover, using it as leverage to implant their missions in Tonkin during the first decades of the French presence. ${ }^{3}$ One character stands out in this process as the most central and most powerful cleric that colonial Tonkin - and perhaps French Indochina - ever saw. This was Paul-François Puginier, Bishop in partibus of Mauricastre, and vicar apostolic of West Tonkin and of Hanoi from 1868 to 1892, a key figure in the establishment and expansion of French rule in Vietnam. Puginier has received a good deal of attention from various writers starting with a pious and hefty hagiography by Father Eugène Louvet as early as $1894 .{ }^{4}$

In the 1880s in the Red River Delta and its lower mountainous periphery, the advance of the French conquest caused many mandarins faithful to the Emperor in Hue - and concerned with maintaining their privileged position - to support the resistance. In response, the conquering French military machine launched its mission de pacification, an unforgiving military campaign that was to last a full decade. These were troubled times, and France's Residents and Governors General in Hue and Hanoi rarely remained in their postings for more than a year. Indeed, 15 came and went in less than 15 years between the nomination of Doctor Jules Harmand in 1883 and the arrival of Paul Doumer in 1897. Their administrations were short-sighted and sometimes brutal. Only a few visionaries among these administrators could foresee the potential of the new protectorate; among them Governor General Antoine de Lanessan, who held the post from June 1891 to December 1894.

In a study published two years before taking up his governorship, the strongly anticlerical Lanessan declared (referring directly to Bishop Puginier) that:

\footnotetext{
${ }^{3}$ Cao Huy, Thuan, Les missionnaires et la politique coloniale française au Vietnam (18571914). Yale: Yale Southeast Asia Studies, 1990.

${ }^{4}$ Louvet, Louis Eugène, Vie de Mgr Puginier, Évèque de Mauricastre, Vicaire Apostolique du Tonkin Occidental. Hanoi: Schneider, 1894.
} 
our representatives have allowed themselves to be more or less consciously dragged towards the missionaries' policy, based on suppressing mandarins and scholars [lettrés], with the consequence of conquering Annam and Tonkin with all the human and financial costs this imposes. ${ }^{5}$

The fact is that in the years following the 1884 Patenotre Treaty establishing the definitive French protectorate over the Vietnamese Empire, a policy of domination and assimilation was applied to the Vietnamese people, chiefly in response to the missionary leadership of Paul Puginier.

In those years Puginier was the most seasoned Frenchman in Tonkin, where he had developed an extensive network of informers among Europeans and Vietnamese alike. He had time to shape his vision for the new protectorate and he intended to make the highest authority aware of it. From the elimination of Regent Tôn Thất Thuyết, a leader of the anti-French resistance, in 1885 to the progressive crushing of all significant resistance in the north (completed by 1896), French military operations were stimulated by Puginier's policies and actively benefited from strategic information on the movements of the Vietnamese 'rebels' provided through the missionary network - often obtained in the confessional. ${ }^{6}$ Armed resistance was significantly undermined by the acquisition of thousands of new Catholic converts to the French cause every year in the delta and its immediate periphery.

Coming from the MEP seminary in Paris, Puginier first set foot in Indochina in 1858 and was made vicar apostolic of West Tonkin in 1868 at the young age of 33, following the death of his predecessor Joseph Theurel; he retained this position until he passed away in 1892. He knew the country, its language and its inhabitants like no other European at the time thanks to many years of missionizing in his vicariate, and was a strong believer in his motherland's civilizing duty towards the Vietnamese. Puginier was a mediator between local authorities and Jean Dupuis and Francis Garnier during their 1873 coup de force in Hanoi and played a decisive role in the installation and maintenance of the French Concession on the banks of the Red

${ }^{5}$ De Lanessan, Jean-Marie-Antoine, L'Indochine française, étude politique et administrative. Paris: Alcan, 1889, 711. See also De Lanessan, Jean-Marie-Antoine. La colonisation française en Indo-Chine. Paris: Alcan, 1895. In 1906-7, back in Paris, Lanessan tried in vain to have anti-clerical laws applied to the colonial system; Tuck, Patrick. French Catholic Missionaries and the Politics of Imperialism in Vietnam, 1857-1914: A Documentary Survey. Liverpool: Liverpool University Press, 1987, 338.

${ }_{6}^{6}$ Cao Huy Thuan, Missionnaires et la politique coloniale, 282. 
River, the initial French foothold in Tonkin in the 1870s. In 1878, he sent the first - unsuccessful - Catholic mission to Laos, a prelude to its annexation to French Indochina fifteen years later. In the early 1880s, stimulated by the expansionist policy of President Jules Ferry in France with the support of Bishop Charles Freppel, Puginier made use of his diplomatic skills and his contacts high up in the Vietnamese circles to help open the way for a permanent French presence in Hanoi in 1883 and for the subsequent conquest of Tonkin.

In 1884, at the request of the commander of French forces in Indochina, Puginier moved from the mission's headquarters in Ke Sơ (near Kiện Khê in present-day Hà Nam province) to take up residence in Hanoi and assist the colonial authorities in the pacification of Tonkin. ${ }^{7}$ Between that date and his death, which occurred at the peak of his influence, Puginier stamped a dominant Catholic presence on Hanoi, symbolised by the erection of the Saint-Joseph Cathedral in 1886. De Lanessan considers that Puginier's influence after 1883 was so important that most of the actions of French authorities were directly inspired by his ideas. ${ }^{8}$ The long-term impact of his influence on the authorities both in Tonkin and in France, and his conceptualisation and management of the opening up of Tonkin to missionaries' work, played a decisive role in shaping the political background and the working conditions for all the French missionaries who subsequently penetrated Tonkin and its highlands.

\section{Establishment of The Upper Tonkin Vigariate}

Shortly after Puginier's death in 1892, Pierre Gendreau, Bishop of Chrysopolis in partibus, was appointed vicar apostolic of West Tonkin. Of even longer apostolic longevity than his predecessor, Gendreau was to remain at his post until 1935; he pursued many of Puginier's visions and projects and ensured that his elder's spirit would endure. One such project, colonial expansion in the highlands, resulted in the detachment from West Tonkin in 1895 of the new Upper Tonkin vicariate. As mentioned in Chapter 5, the new entity consisted of all the former's northern and western mountainous frontier, a substantial chunk of land

${ }^{7}$ Puginier's relocation is mentioned in Hocquart, Charles-Edouard, "Trente mois au Tonkin." Tour du Monde, ler semestre, 1890, 117.

${ }^{8}$ De Lanessan, Indochine française, 715. 
of around $60,000 \mathrm{~km}^{2}$, nearly one-fifth of present-day Vietnam. This entity was later known as the Hưng Hoá vicariate after the name of the town where the new vicar apostolic See was installed. This town was located close to the delta, near the confluence of the three main rivers that drain the northern mountains, a location perceived at the time to be at the demographic centre of the vicariate.

In the 1860s, Bishop Theurel had asked for the creation of an Upper Tonkin vicariate, but the time was not ripe and support for the initiative did not materialise. It is only fitting that this formalisation of a missionary administration over an otherwise remote borderland occurred concurrently with the end of the 'pacification' period and the start of the French takeover of Laos, and at the precise moment when the China-Tonkin border was officially agreed upon between Chinese and French representatives. Once established though, how was the new vicariate to be delineated given that, as summarized in the following quote by Ramond, no missionary exploration had ever been undertaken beyond its lower portion?

The immense space unfolding between Tuyen Quang, Lao Kay and the Chinese border has not heard the Gospel yet. [...] It is difficult to define where the border to the West is. There lies an immense and still little known territory which has never seen a missionary. ${ }^{9}$

Geographically, western Tonkin had long encompassed three distinct regions: a deltaic plain inhabited by Kinh rice growers; a portion of low-altitude rolling hills comprising the sectors of Phú Thọ and Hưng Hoá with the lower parts of the Black and Clear River valleys, inhabited chiefly by various Tai-speaking montagnard groups; and a high region culminating at 3200 metres with a maze of high valleys and schist plateaus, inhabited by an array of little-known ethnic groups. This latter region formed a large portion of Tonkin's territory which, in spite of the recent establishment of direct colonial military rule in 1891, was only nominally included in the missionary domain.

The first vicar apostolic of the Upper Tonkin vicariate was PaulMarie Ramond (b. 1855), who arrived in Tonkin in 1881. As a simple missionary, Ramond was first assigned to the district of Nam Xang fifty kilometres south of Hanoi, then moved to Hưng Hoá when he was made Bishop of Linoë in partibus and put in charge of the new vicariate

${ }^{9}$ Comptes-rendus, 1895, p. 185; this source mentions Theurel's request as well. Comptesrendus are held in the MEP Archives. 
in October 1895. Like his colleague Bishop Gendreau in Hanoi, Ramond enjoyed a long tenure, remaining in his post for 43 years, nearly the entire length of the vicariate's existence.

In his earliest comptes-rendus from Hưng Hoá, those for 1895-6, ${ }^{10}$ Ramond first sets the scene by telling his readers about the loss of three consecutive harvests due to a drought that caused a severe famine. To make things worse, a major cholera epidemic broke out, killing ten per cent of the vicariate's population. After this grim prologue, the Bishop then proceeds to introduce his new domain. This tour is most useful for assessing the exact state of the missionary progress in the mountains at a time when the Upper Tonkin vicariate comprised the (then) provinces of Sơn Tây, Hưng Hoá and Tuyên Quang, as well as the western part of the Third Military Territory, all of the Fourth Military Territory, and the Commissariat de Van Bu in the west which coincided with the Sip Song Chau Tai domain of the Deo family. As already mentioned, in 1891 the colonial administration of the upper region along the Chinese border was given to the military, and the area was divided into Military Territories instead of regular provinces. Their shape and boundaries varied greatly over the years while their total number never exceeded five, spreading from Mon Cái to the East to Phongsaly in Laos to the West. ${ }^{11}$ The Upper Tonkin vicariate bordered Yunnan to the North, the right bank of the Lô River and (downstream from the junction of the two) Red River to the east, the western limit of the Đà River basin to the west, and Hanoi province to the south. Its population at the time was roughly estimated at 2.5 million, although no one had really any idea of the exact figure. ${ }^{12}$ In other words, most of the mountainous areas of Tonkin and their populations were part of this vicariate except for the gradually sloping ranges east of the Lô. The latter, as we have already seen, belonged to the Spanish Dominican mission while being

\footnotetext{
10 'Rapport annuel de la mission du Haut Tonkin pour l'année 1895-1896', Comptesrendus 1896. MEP archives no. 711-5, Vicariat apostolique du Haut-Tonkin.

${ }_{11}$ Teston Eugène and Maurice Percheron, L'Indochine Moderne: Encyclopédie administrative, touristique, artistique et économique. Paris: Librairie de France, 1931, 254.

12 That is a very rough estimate. Forty years later, a better-informed source gives a figure of 1.3 million for the same territory; Vandaële, Georges (Bishop). "Mission de Hung Hoa (Tonkin)." Les Missions Catholiques, pp. 396-414, 1936. The borders of the vicariate are from Girod, Léon. Dix ans de Haut-Tonkin. Paris: A. Mame et Fils, 1899, 54. Later, in the administrative divisions of the early 1930s, it included seven provinces: Phú Thọ, Sơn Tây, Hoà Bình, Sơn La, Yen Bái, Lào Cai, and part of Tuyên Quang; and two military territories: Lai Châu and part of Hà Giang (Vandaële, "Mission de Hung Hoa (Tonkin)", 398).
} 
under French military administration as the First, Second and eastern part of the Third Military Territories.

To expand this portrait first painted by Ramond, we know from various other sources that virtually all of the Christian hamlets in what was known in Vietnamese as the Xứ Đoài upland district - also nicknamed the 'Tonkinese Switzerland' by missionaries ${ }^{13}$ - were transferred to the new Upper Tonkin vicariate. These hamlets belonged to ten established parishes all located in the provinces of Sơn Tây and Phú Thọ on the outskirts of the delta, situated mainly in the lowlands and inhabited by Kinh. Only two settlements were set up outside this Red River corridor, constituting the southwest limit of missionary activity, west of the Black River. To the north, the limit of activity was Yên Bái on the Red River. To the east, between the arms of the lower Clear and Red Rivers east of Hưng Hoá town, there was one parish centred on the vicariate's seminary, while the furthest existing mission up the Lô was in Tuyên Quang. There were also five garrison towns - Sơn Tây, Yên Bái, Tuyên Quang, Lào Cai and Hà Giang - each with a mobile military hospital (ambulance) to which a chaplain (aumônier militaire) was attached.

\section{Missionaries in the highlands}

While their Bishop was busy with the administration of the vicariate, individual missionaries were starting to walk through the uplands. As the mountainous section of the Upper Tonkin vicariate was being opened to missionizing, clerics penetrated these previously little-known regions - little-known from a European point of view, that is - and made contact with their populations. Let us now trace the movements of these pioneers.

Prior to the French arrival in Tonkin, the provinces of Sơn Tây and Phú Thọ had already been officially incorporated into the Vietnamese imperial domain. The latter province had seen missionary activity over the nineteenth century that involved three of the most celebrated figures of MEP martyrology: Jean-Charles Cornay (in Vietnam 1831-7), Augustin Schoeffler (1847-51) and Pierre Néron (1848-60), all publicly executed in the provincial capital of Sơn Tây. Generally speaking, by 1895 only a few missionaries had seen the mountainous areas at all,

${ }^{13}$ Girod, Léon. Souvenirs franco-tonkinois 1879-1886. Paris: Desclée, de Brouwer \& Cie, 1900, 271. 
and when they did, it was primarily to provide religious services to the colonial troops on the march. Consequently, little if any missionary attention had been paid to the highland inhabitants. ${ }^{14}$

In the early 1880s Father Léon Girod $[1879]^{15}$ had been the first missionary sent by his bishop up the Red River valley, reaching a higher point than any of his known missionary predecessors. In 1886, a decade before the creation of the Upper Tonkin vicariate and five years before the establishment of the military administration along the border, he and Father Ambroise Robert [1883] were sent to take charge of the little-known part of the mountainous segment of the then West Tonkin vicariate - the Xú Đoài, the West Country. Xứ Đoài comprised the (then) provinces of Hưng Hoá and Tuyên Quang and included the very recently established military stations of Yên Bái, Tuyên Quang and Lào Cai. The two priests probably settled in Phú Thọ and from there, could spread out to reach these garrison towns. Girod recorded his observations, which were published in several issues of the weekly magazine Les Missions Catholiques and were later grouped into a book which appeared in $1899 .{ }^{16}$

It is difficult to calculate the exact number of missionaries sent into the mountains at the time of the creation of the Upper Tonkin vicariate. We know from the comptes-rendus that in 1895 out of a total of 56 MEP priests active in the West Tonkin vicariate, the seven who were already working in the Xú Đoài district were automatically transferred to the new vicariate. ${ }^{17}$ These seven missionaries were: Jean Robert [1882], attached to the Sơn Tây garrison; Emile Duhamel [1890], in charge of the parish of Bách Lộc; on the Clear River, Julien Chotard [1893] with the troops in Tuyên Quang and Mathurin Pichaud [1889] in the upstream parish of Bau-no; on the lower Black River, Eugène Brossier [1891] was in Đức Phong; and on the Red River, Pierre D'Abrigeon [1892] was in charge of the three parishes of Yên Tập, Dư Ba and Song-chay, with Léon Girod further upstream in Yên Bái. Within a year of the creation of the Upper Tonkin vicariate, five additional mis-

\footnotetext{
${ }^{14}$ Launay, Adrien. Atlas des missions de la Société des Missions Étrangères de Paris. Lille: Desclée, de Brouwer et Cie, 1890.

${ }^{15}$ Square brackets are used to indicate the year of the missionary's arrival in Tonkin.

${ }^{16}$ Girod, Dix ans.

17 Actually, this figure is valid for the year 1893, when the total number of native and non-native priests in the West Tonkin vicariate was 163, including these 56 Frenchmen (Comptes-rendus, 1893).
} 
sionaries were re-assigned from elsewhere to support this expansion. These were Ambroise Robert, who became superior of the vicariate's seminary near Hưng Hoá until his death in 1896; Amans Bessière [1883] who succeeded him; Louis Méchet [1883]; Pierre Chatellier [1891]; and Pierre Granger [1894]. This inaugural team also included twelve Vietnamese priests whose names are not known to us.

Every missionary posted in the upland region had a joint assignment. Chotard, located on the Clear River wrote,

Here, I have three sorts of ministry. First, my legionnaires, who for me are like my sons. [...] My second ministry puts me in touch with the French colonists established here. [...] Finally, I have laid the foundations of a Christian community among the pagans. ${ }^{18}$

Indeed, several missionaries in Upper Tonkin mentioned early on in their reports that ministering to the troops and the European settlers took all their time, leaving little or no opportunity for proselytising the natives, let alone investigating their customs and languages.

Within a few years of the creation of the new vicariate, missionary activity expanded. Since the mid-1880s, Yên Bái was an important colonial military outpost visited by surrounding populations as a market town, and was seen by the military commanders as one of several promising locations where some Christian Kinh could be persuaded to resettle and contribute to building a strong outpost on the outer edge of the delta. To attract such migrants to a region where lowlanders had been traditionally reluctant to settle, Colonel Théophile Pennequin, the chief 'pacifier' of Tonkin, decided to increase the religious presence there and helped to set up a formal Catholic mission in 1893. Girod, by then the most experienced missionary in the upper region, was immediately assigned to it and in 1894 he visited the military and customs post of Lào Cai further North for the first time. This was where the headquarters of the Fourth Military Territory had recently been established with one company of legionnaires. Lào Cai now needed a missionary to serve its European population and in September 1897 Girod became the first resident missionary there. ${ }^{19}$ Father Méchet

18 Comptes-rendus, 1895.

19 Swift to stamp a visible Catholic presence on the Sino-Tonkinese border, Girod had a church erected within a few months. It comes as an amusing quirk of fate that the stones used to build that first church came from a former foe's stronghold, the Black Flag leader Liu Yongfu's recently dismantled citadel located nearby on the right bank of the Red River. For more on Girod, see Méchet, Louis. "Léon-Xavier Girod, 
replaced him in Yên Bái, where the garrison and the growing number of migrants required a priest in residence. In addition, come 1900, Jean Gauja [1896] was the resident priest for Tuyên Quang, another highland town experiencing a similar pace of development.

During the Doumer governorship of French Indochina (1897-1902), further missions were opened in the mountains outside the main river valleys and garrison towns. The first opened in July 1899 when Edouard Karrer [1897] was sent to reside with Father D'Abrigeon among the Man (Yao or Dao) north-west of Hà Giang town close to the Chinese border. Concurrently, Auguste Blondel [1898] had been visiting the tribes in the mountains between Yên Bái and Tuyên Quang in order to assess the possibility of setting up a mission there. The next year, Fathers Alexandre de Cooman [1895] - future bishop of Thanh Hoá further south - and Joseph Laisi [1895] were sent among the Muong of the lower Black River in 1900, with a view to expand their operations further upstream in the direction of the Thai domain of the Sip Song Chau Tai to the north-west. In 1901, Granger and newcomers François Jordan [1898] and Antoine Antonini [1899] were sent to Nghĩa Lộ between the Red and Black Rivers, which was considered a remote district with

different tribes from an heterogeneous population: Tho, Muong, Meo, Man, Xa. The Tho and the Muong dwell in the valleys in houses on stilts, while the Meo, the Xa and the Man attach their houses to mountain slopes and hillsides surrounding the plain. ${ }^{20}$

In a significant departure from the priority given to servicing Europeans and making brief visits to upland villages from a nearby garrison town, these latter three missionaries appear to have been the first who actually elected to live among the montagnards - Granger with the Meo (Hmông), Jordan and Antonini with the Tho (Tày) - in order to study vernacular languages, an activity that quickly became their main occupation. Following the same trend, up the Clear River, François-Marie Savina [1901] opened a new mission in 1906 at Vĩnh Tuy among the Tho and the Man, roughly mid-way between the garrison towns of Tuyên

missionnaire du Haut Tonkin.” Bulletin de la Société des Missions-Étrangères, pp. 408-416, 472-480, 539-546, 597-605, 1925. On the Black Flags in Lào Cai see McAleavy, Henry. Black Flags in Vietnam. The Story of a Chinese Intervention. London: George Allen and Unwin Ltd., 1968.

${ }^{20}$ Comptes-rendus, 1901. 
Quang and Hà Giang. These initiatives by Granger, Jordan, Antonini and Savina, the latter a key figure discussed in Chapter 8, represent the point when MEP missionaries at last came into steady contact with the highlanders, thus marking the start of the production of missionary texts and ethnographic studies on Tonkin's highland societies.

\section{Lull AND Decline}

In spite of this active expansion, proselytising in Upper Tonkin did not yield the results that the missionary establishment was hoping for, as missionary Laisi reported to his Bishop with regards to the lower Black River region:

The almighty authority of the quan-lang [local leaders] is the main obstacle to conversion. Undisputed masters, they are wary of the missionary whom they wrongly fear will diminish their prestige. They make use of all means to keep those who might want to free themselves enslaved. [...] Polygamy and the excesses it entails, opium, inequity, do not allow much hope of converting these rulers. ${ }^{21}$

In fact, a large proportion of the baptisms recorded each year throughout the vicariate were of candidates on their deathbed: "The posts recently set up in wholly pagan regions have only yielded a few baptisms in articulo mortis." ${ }^{22}$ In those days - and since the earliest times of European colonial expansion throughout the world - this half-success was acceptable though not entirely encouraging. In the absence of better yields it was even rather morbidly sought after: "An epidemic of smallpox promised a substantial harvest of souls", wrote Ramond in 1902 when summing up that year's baptism figures for the Board of Directors in Paris. In fact, so slow was the progress in converting the uplanders that even three decades later Gustave Vandaële still observed that due to resistance, the ruggedness of the terrain, and the unhealthy conditions in the mountains, "conversion will be very laborious for a long time to come"...23

In comparison, the portrait of the Kinh in the lower reaches of the vicariate along the main river valleys was more encouraging. By 1910, after 15 years of activity, the Upper Tonkin vicariate included a total of

21 Ibid.

22 Comptes-rendus, 1902.

23 Vandaële, "Mission de Hung Hoa (Tonkin)", 403. 
115 Christian settlements, nearly all located along the main rivers and land routes. A significant factor that increased the number of Catholics in the vicariate was a specific historical circumstance. During the first decade of the twentieth century, the construction of the Haiphong-Yunnansen (Yunnan-Tonkin) railway had brought an important transient population of railway workers from various lowland origins to the upper Red River valley that for several years formed the largest portion of the increase in the number of Christians in Upper Tonkin. This success was only temporary, however, and the completion of the railway in 1909 meant that most of these labourers left the region, creating a lull in the local economy and leaving towns like Yên Bái and Lào Cai with a sudden and substantial population decrease. On the other hand, the new railway channel, convenient for internal colonisation in the high region, started to appeal to Kinh migrants from the lowlands who selected these same towns as their preferred area of relocation. Even so, this population movement upstream remained meagre.

According to Launay, by 1912 Upper Tonkin had a Catholic population of 28,350, with one bishop, 26 French missionaries, ${ }^{24} 25$ indigenous priests and 114 catechists, with two seminaries lodging 84 indigenous (chiefly Kinh) students. By 1920, a total 41 French missionaries had been assigned to work in the Upper Tonkin vicariate while the number of active priests there, inclusive of those with administrative and educational duties, was 50, of whom 24 were French and 26 Vietnamese. ${ }^{25}$ In total, 23 parishes were comprised of 271 Christian settlements. By 1920 however, the missionary expansion in the highlands had virtually stalled due to a number of adverse factors. Unlike the Central Highlands, colonial support for additional proselytising in Upper Tonkin had

${ }^{24}$ In addition to the names already given, other missionaries who were working or had worked in Upper-Tonkin by 1910 were: Gustave Hue [1895], Pierre Quioc [1897], Jean Jacques [1898], Gustave Vandaële [1899] who three decades later inherited Ramond's mitre, Paul-Marie Jaricot [1900], Bruno Blache [1900], Charles Bourdin [1901], Marie-Joseph Aigouy [1901], François Marias [1902], Louis Chapert [1903], Jean Massard [1903], Emile Proult [1904], Ambroise Tissot [1904], Louis Cornille [1905], Paul Gros [1905], Benoit Puyoo [1907], Prosper Suffray [1907], Edmond Pierchon [1907], and Pierre Gautier [1910]. (Brebion, Dictionnaire, 354-97).

${ }_{25}$ (Anonymous). "Mission du Haut-Tonkin. Aperçu historique." Bulletin de la Société des Missions-Étrangères de Paris, 1922, 551. The figures for 1912 are from Launay, Mémorial. Citing the MEP Comptes-rendus, Tuck gives for that same year the figures of 24,160 Catholics, 27 French priests, 20 native priests and 97 native catechists; Tuck, French Catholic missionaries, 316-21. 
irrevocably slipped in the face of more urgent needs - a testimony to the low priority that evangelism in these highlands held for the colonial State once the initial push to the Chinese border and the 'pacification' campaign had ended. With the rise of Vietnamese radicalism, the threat to the colony appeared to come more and more from within the Kinh population itself rather than from beyond the borders of Indochina. ${ }^{26}$ The need to penetrate highland societies for strategic purposes had thus subsided and the policy of military administration of the territories along the border with China was gradually abandoned in favour of the establishment of a regular civilian administration. In Hanoi, the item at the top of the colonial agenda was mise en valeur, the 'realisation' of the colony's economic potential. At the same time, recruitment of new missionaries in France had become less successful, due in particular to the fact that the First World War had taken the lives of many young men who would have been potential priests, while those remaining were needed at home and in industry. In addition to the war, the Great Depression was to cause the financial misfortune of many long-time donors to the MEP in both France and Indochina, thus undermining its capacity to recruit, train and send new missionaries, in addition to the maintenance of the existing infrastructure, staff, native students and catechists in Indochina and elsewhere. Consequently, the conditions for further missionary expansion had vanished and the mere survival of existing operations was now at the top of the missionary agenda. As a result, at the fullest extension of the missionary effort in Upper Tonkin, a great many highland hamlets in remote valleys or distant ranges remained untouched.

By the mid-1930s evangelism in the mountains had become an enormous burden carried out only by a few ageing priests. Taking stock of the situation, Vandaële, in an 18-page account published in Les Missions catholiques in 1936, produced a low-key and realistic appraisal of the situation reflecting the fin de règne atmosphere in Tonkin linked to the aged and now feeble bishops heading both the Upper and West Tonkin vicariates - Ramond and Gendreau. Vandaële declared that

${ }^{26}$ See Tai, Hue-Tam Ho, Radicalism and the Origins of the Vietnamese Revolution. Cambridge: Harvard University Press, 1992. Salemink shows that by contrast, during the 1930s and 1940s missionaries in the Central Highlands were actively supported by the colonial State as part of a divide-and-rule strategy aimed at separating the highland population from the lowland Kinh; Salemink, Ethnography of Vietnam's Central Highlanders. 
in the other provinces of the mission [outside Sơn Tây and Phú Thọ on the Red River], there are still only a few Christians and the lack of personnel has not yet allowed the evangelising of the numerous tribes in the upper region.

At that time the total population in the upland region, as stated in the 1932 yearbook for the colony, was a relatively low figure of 409,000 for the seven mountainous provinces plus two remaining Military Territories, compared with 558,000 for the two lowland provinces of Sơn Tây and Phú Thọ alone. ${ }^{27}$ More precisely, outside these two lower provinces, missionary work in the part of Tuyên Quang province situated within Upper Tonkin - that is, the right bank of the Clear River - was focused on the Kinh valley settlers who moved there in search of economic opportunities as labourers in coal and zinc mines. In the town of Yên Bái, the immigration of Kinh from the delta had been steady. In 1936, these migrants, along with the European population stationed on location, formed the bulk of the target population for the missionaries' ministry.

A further indication that missionizing in the mountains had receded to the point that no progress towards converting the montagnards appeared to have been made, was the fact that the permanent mission in Yên Bái town was still, in Vandaële's words, limited to providing "a means to visit the military posts in the Upper Region and bring spiritual succour to the brave troops." Indeed, in the whole of Vandaële's account, the only mention of non-Kinh populations occurs when talking about the market town of Nghĩa Lộ, the domain of missionary Doussoux and one of the first missions set up amongst the highlanders:

Since 1900 in that region, there have been missionaries who try, amidst great difficulties and at the cost of their own health, to penetrate the aboriginal tribes. Alas! Results do not match expectations. The two colleagues who are now in that region of fevers are in charge of 700 Christians, all Vietnamese who came from the delta as traders or labourers hoping to enrich themselves. Tentative evangelisation has been done among the mountain tribes, notably among the 'Meo' on mountain tops; may God bless them and yield positive results. ${ }^{28}$

${ }_{27}$ Vandaële, "Mission de Hung Hoa (Tonkin)", 410, citing the Annuaire officiel for 1932; the quotation is from p. 407. The figures are as follows: Sơn Tây, 256,000; Phú Thọ, 303,000; Yên Bái, 62,000; Lào Cai, 38,000; Hoà Bình, 53,000; Tuyên Quang, 40,000; Sơn La, 86,000; and the military territories of Hà Giang (70,000) and Lai Châu (60,000).

28 Ibid., 408. 
In Lào Cai province on the Chinese border, Christian settlements were scattered along the railway line and only the mission's rest house, up in the Chapa ( $\mathrm{Sa} \mathrm{Pa}$ ) hill station, reported some evangelism work among the Meo. Vandaële recorded 30 converts among them by 1934, when Doussoux had to step in as a temporary replacement after the departure of his colleague Savina. Doussoux and Savina appear to have shared the distinction of having converted the only mountain populations in the whole vicariate: 'Among the aboriginal populations: Tho, Man, Mèo..., the latter only have been successfully evangelised in two locations within the Mission'. ${ }^{29}$ In the provinces of Hoà Bình and Sơn La and the Military Territory of Lai Châu, all located in the Black River basin along the western edge of Upper Tonkin, missionary activity was still non-existent four decades after the formation of the vicariate. In that region, where the Thai of Deo Van Tri and his heirs had been firmly attached to the French cause since 1889, the colonial authorities considered missionizing as less politically urgent than elsewhere. Even, it could be seen as potentially damaging to the crucial alliance established with these groups. ${ }^{30}$ This may well be a case where avoiding the use of the missionary spearhead to penetrate a remote population was considered a preferable colonial strategy.

By the end of the 1930s, the missionizing task for the MEP in the areas beyond the Tonkinese lowlands and the valley floors was daunting, and both human and financial resources were drained. Faced with a shortage of able bodies and about to succeed Bishop Ramond and oversee a decrease in missionary activity, Vandaële found some comfort in the hope that:

Trappists or others will come, cut down the bush, cultivate this immense forested region and install their monasteries amongst an important population; in Upper Tonkin, huge spaces of solitude await to be transformed with work and prayer into Christian fields of progress.

The suggestion of breaking up the long MEP monopoly on missionary activity in Upper Tonkin appealed to the future Bishop, who knew that he was facing a very difficult situation. At that point, in desperation

\footnotetext{
${ }^{29}$ Comptes-rendus, 1940, p. 83.

30 See Michaud, Jean. "The Montagnards in Northern Vietnam from 1802 to 1975. A Historical Overview from Exogenous Sources." Ethnohistory, vol. 47, no. 2, 2000. In the west only one mission had been established - in the provincial capital of Sơn La in 1938.
} 
perhaps, he even came to suggest that the MEP should completely hand over the vicariate to another missionary society:

What a considerable area and how many people that would be needed to start and maintain evangelising there! Would perhaps another missionary society accept to take charge of it in the future? At the moment, considering the small number of apostolic workers in the vicariate and the advanced age of most of them, it would be difficult to hope for any results. $^{31}$

Vandaële was not given the opportunity to go further along that road, however, as the Second World War broke out in 1939, and many aspects of French life in the colony came to a standstill. Evangelism among the highlanders ceased for virtually all European missionaries in Upper Tonkin, though it continued among the Kinh in French-controlled parts of the delta. The successive blows of the Japanese coup in March 1945, the unilateral declaration of independence by Ho Chi Minh in September 1945, the Republican Chinese occupation through early 1946, and the outbreak of a long and deadly war of independence the following December all sealed the fate of French missions in upland northern Indochina; missionaries and their superiors had to fall back to Hanoi. ${ }^{32}$ On May 15, 1947, the abandoned Episcopal See in Hung Hoá was destroyed preventively by the French air force. Only missionaries drafted and attached to the troops would occasionally return to the highlands during the military operations of the First Indochina War, such as Jean Idiart-Alhor who returned to Chapa with the occupation troops in 1947, staying there until his assassination one year later. The others served in lowland urban parishes, hospitals and garrisons until the Geneva agreements of July 1954 definitively forced them out of the young Democratic Republic of Vietnam - North Vietnam.

In the end, as a missionary venture, the Upper Tonkin vicariate, over the course of its fifty-odd years of existence, was at best a moderate success. Results in the lowlands dramatically outshone those in the highlands and though this discrepancy was deplored by the vicariate's last Bishop, Gustave Vandaële, it was clearly not a major concern to the religious establishment as a whole. From the very start, missionizing among the dispersed highland populations was not a priority, and history has shown that it never truly became one. Rather, sending

31 Vandaële, "Mission de Hung Hoa (Tonkin)", 409.

32 Comptes-rendus, 1941-7, p. 67. 
trustworthy emissaries was considered necessary only in direct connection with the military takeover and the administration of the mountain periphery. Who was better suited to this task than the Catholic priest? The colonial authorities knew well that

missionaries are always admirably informed, they have always foreseen the movements and incursions of Chinese bands, the infiltrations of rebels, famines, in a word any event that plagued Tonkin. ${ }^{33}$

${ }^{33}$ Monteuuis, Âme d'un missionnaire, 232 (note 2), quoting an article titled 'Les missionnaires de M. de Lanessan’ from the newspaper L'Indépendance Tonkinoise (n/a). 
Jean Michaud - 978-90-47-42021-7

Downloaded from Brill.com๑4/26/2023 $\odot 9: 56: 23 \mathrm{AM}$

via free access 
PART FOUR

MISSIONARY AUTHORS AND THEIR TEXTS 
Jean Michaud - 978-90-47-42021-7

Downloaded from Brill.com๑4/26/2023 $\odot 9: 56: 23 \mathrm{AM}$

via free access 


\section{CHAPTER SEVEN}

\section{MISSIONARIES AND THEIR TEXTS}

The stage is now set. The historical, political, and ideological background of the missionary as an agent of the religious establishment, but also an agent of the colonial state and an emissary of modernity, has been explored and made explicit. It is now time to meet individual MEP missionaries who most actively contributed to the ethnography of the highlands in the Upper Tonkin vicariate and adjacent parts of southwest China. ${ }^{1}$ This fourth section of the book is divided into two chapters that reflect a divide amongst these missionaries, namely between the trail blazers, and the next generation. Chapter 7 explores a sampling of missionary texts that are selected, put in context, and presented with an appraisal of their ethnographic value. These texts were produced roughly within 15 years of the creation of the Upper Tonkin vicariate, that is to say between 1895 and 1910. They exemplify missionary publications in the early stages of proselytizing in these mountains and among those remote peoples, when the frontrunners of the religious apparatus in these lands had virtually no one else to ask for help. After the 1910s, I argue, a second generation of missionaries took over from the path-breakers, a generation who could use the experiences and the language-training tools that their predecessors had left behind. This second generation, who started the production of a more mature, better rooted form of ethnographic writing, will be represented by three of its most distinguished spokespersons, Fathers Alfred Liétard, Paul Vial and François Marie Savina. But for now, the first steps.

Initially, the handful of missionaries joining the Upper Tonkin vicariate in 1895 had no understanding of the variety, let alone the exact identity, of the populations dwelling within the boundaries of their new mission. At best, some of the disembarking priests had perhaps - and I insist: perhaps - laid their eyes on some texts published by their lay forerunners or peers who had ventured into the mountains. Globally

1 This chapter is related to an article published in 2004 in the journal Asian Ethnicity (Vol. 5, number 2, pp. 179-194) and titled 'Missionary Ethnographers in Upper Tonkin: The Early Years, 1895-1920.' That article has been significantly edited here. 
however, no formal effort was deemed necessary at the end of the 19th century by ecclesiastical authorities for missionaries to learn more through such works. The reluctance to learn from non-religious sources has to be linked to the MEP superiors, who as noted in Chapter 4, did not see fit to develop that side of the missionaries' curriculum. In true missionary tradition, learning about the natives was to start only with the first encounter. As a consequence, the newcomers' cultural preparation to meet the 'savage' Other was, in plain terms, tantamount to nil.

Before 1895, as we have seen in the previous chapter, missionaries had produced virtually no description of the peoples of Upper Tonkin. With the Vietnamese language as their only communication tool, the first missionaries to reach the non-Kinh populations in the highlands quickly found themselves helpless, incapable of being understood except by their entourage and the occasional half-Vietnamized middle-person. Accordingly, priority had to be given to learning vernacular languages. In those early days, before lexicons, grammars and dictionaries had been produced, learning unwritten languages such as Hmong or Khmu could be achieved only through a lengthy period of intense contact with the speakers, almost invariably on location. This principle had been learnt from the earliest time of proselytising, in 17th century Nouvelle France for instance, and French missionaries had long realised that linguistic skills were key to successfully winning hearts and minds.

But learning so many languages in such difficult circumstances became an overwhelming task. For many, managing to learn Vietnamese while in residence at the seminary in Kẻ Sở, Hanoi, or Hưng Hoá had been taxing enough. The added predicament that more was to be learned in the field, with considerably less support, meant that far from everyone was fit to stand the test. Only the more daring missionaries could go on to live with the indigenous populations for substantial periods of time, in full knowledge of what awaited them. As the head of the Upper Tonkin vicariate at this time, Bishop Ramond, put it:

The beginnings shall be painful; there will be a need to learn their languages, quite different from Annamite, to get used to their mores and to the generally unhealthy climate. As everywhere, that will be the price to pay for the salvation of souls. ${ }^{2}$

Within a decade however, these pioneers who had managed to learn vernacular languages in the mountains could in turn, teach their younger

\footnotetext{
2 Comptes-rendus 1899-1900.
} 
colleagues, and in time learning tools were produced that were to help the next generations of missionaries there. Indeed, perhaps the most important contribution by missionaries to facilitate the ethnography of highland groups in Tonkin was their production of linguistic material. This would become an invaluable tool to whoever would need to communicate with the highlanders in the future, be it other missionaries, administrators, the military, or later, scholars.

\section{COMPTES-RENDUS}

The prose of MEP missionaries shows a range of differences in style, content, and intentions, particularly between the priests in contact with the local population, and their superiors in urban settings. Whilst Paul Puginier, the late Bishop of the West Tonkin vicariate, was preoccupied with political issues and long-term strategies aimed at taming the Mandarins and promoting France, his successor Bishop Gendreau had inherited the uneasy job of finding a modus vivendi with very vocal European and anticlerical critics of the missions back home. A form of anti-clericalism that had become associated with the Third Republic influenced both Indochina and France. ${ }^{3}$ In addition, in the particular case of the Upper Tonkin vicariate, Bishop Ramond was hard pressed to attract potential benefactors to the cause of missionizing in an understaffed and oversized vicariate.

The missionary cohorts on the other hand were predominantly concerned with the practicalities of daily life in their mission and the genuine wellbeing of their converts, at least for some among them. Typically, in their written reports to their Bishop, outposted missionaries routinely stressed the progress made in God's name and asked for additional support to help alleviate the suffering around them - and theirs by the same token one would assume. If, as we saw, Puginier personified the fighting political churchman, in contrast the dedicated field practitioners embodied the 'selfless' apostles of God. Consequently, writing ethnography was obviously the privilege of the rank and file of the missionary organisation in direct contact with locals.

The production of ethnographic text by missionaries in the Upper Tonkin vicariate only started after all the remote areas fell under the full

${ }^{3}$ Conklin, Alice L. A Mission to Civilize. The Republican Idea of Empire in France and West Africa, 1895-1930. Stanford: Stanford University Press, 1997. 
control of the colonial military, around 1895. By contrast, at the other end of the time span retained for this chapter, by the 1910s, representatives of most remote groups had been met, their land charted, their languages studied, appropriate dictionaries and language tools produced, and enough converts made among these montagnards to facilitate the interaction between the missionary system and the natives. As Father Vandaële had explained to his readers in our Chapter 6, no further expansion was to occur after the 1920s when the growth phase of missionary work into the uplands of Upper Tonkin ended. ${ }^{4}$ By then, in a purely bureaucratic understanding of ethnography, religious authorities considered that the study of the natives had been advanced enough so that the knowledge available was sufficient to support routine conversion in the existing missions, which was all that was deemed necessary. With further studies thereafter unwanted, only the odd missionary was to carry out enquiries of an ethnographic nature, motivated by personal curiosity, and for some, scholarship. But I anticipate.

Most missionaries in the field regularly wrote a personal diary and maintained a steady flow of correspondence with their colleagues, families, friends, and mentors. For those missionaries located in the highlands, such day-to-day descriptions of their life among the highlanders must have contained observations that would be of keen interest to anthropology today. However, sadly, for all of the missionaries addressed in this book, such diaries and correspondence were not kept at the MEP archives and appear to have been lost through historical mishaps or unclear family inheritance channels.

Fortunately, most individual missionaries also contributed to the vicariate's annual reports, the comptes-rendus, and a small number occasionally published notes or short articles in religious journals and magazines, and sometimes even a popular book, in which they reported observations based on their experiences. Beyond this, one can also find the odd missionary who, deliberately or not, with a remarkable piece of writing, made what the next generations have judged to be a valid contribution to the ethnology of one group or community. Let us consider the comptes-rendus first.

From the very first year the Upper Tonkin vicariate became operative, we know that individual missionaries were explicitly asked to send annual reports of their activities to their Bishop. Sent to the vicariate's

\footnotetext{
${ }^{4}$ Vandaële, Mission de Hung Hoa.
} 
See in Hưng Hoá, Bishop Ramond, reproducing what he had learned in his early missionary career in Tonkin, asked for such reports to include factual information on the number of new converts in the mission, the number of confessions performed, the number and nature of the schools set up or details on how existing ones were doing, a general recounting of the year's highlights, and an overall commentary. Upon receiving these field reports from the men under his authority, one of the Bishop's responsibilities was to summarise them, quote segments that he judged could put the mission in a good light, and edit a new, condensed version. This final cut was sent to the MEP board of directors in Paris, who could edit the text again or not, depending on the circumstances. At each of these steps, matching with the intent that underpinned these yearly comptes-rendus, we thus find the same logic that had prevailed for centuries in the production of field reports across missionary societies throughout the world; the parallel here is manifest with the Jesuits' Relations of New France discussed in Chapter 3.

As a source of first-hand ethnographic information, from an anthropological point of view, the original texts produced by the missionaries in the field would certainly be the most promising documents to scrutinize, as opposed to the edited fragments kept in the comptes-rendus where only the occasional ethnographic description was allowed to reach the final version. Unfortunately, it appears that those among the original contributions that were not disposed of immediately were stored in the Bishop's See, and as a consequence, it seems they did not survive the vicissitudes of the Indochina Wars.

Perhaps because of the Bishop's editing, or perhaps simply because the yearly reports were put together in haste, the overall impression that one gains from such ethnographic quotes found in the comptes-rendus is that of piecemeal observations on material life, customs, history, or political matters written with no specific structure. This quote from the 1901 comptes-rendus and attributed to missionary Pierre D'Abrigeon is a good example:

The Man originate from China; tall, with a slim face, they dress up in half-Chinese and half-Annamite clothes and are most distinguishable by the huge turban circling their head. They live on the foothills where they establish their terraced rice-fields, and keep a distance with neighbouring tribes who want to enslave them; they remain independent to this day. One finds there a wholehearted hospitality often mixed with indiscreet curiosity; women do not exist in official life, rarely will they eat along with their husbands, their lords and masters, even on festive days; on the other 
hand women play a considerable part in the work life. Daughters are not recorded in the listing of children. Their religious practices consist of worshipping the spirit of the mountain where they live and asking him for peace, the safeguard of health, and excellent harvest. In the case of illness, one consults the wizard in order to identify the spirit causing the illness and select the animals that must be sacrificed to obtain relief. The Man do not cremate their dead: they put them to lie. After wrapping them up in a funeral cloth, they lay the corpses in coffins that are hermetically sealed and kept in their house for three days during which the sorcerer, dressed in an embroidered costume similar to the Annamite theatrical costume and assisted by two men dressed as women, recites prayers amidst dancing, towards the happiness of the deceased. ${ }^{5}$

By including in their annual reports to their Bishop (exoticized) descriptions of peoples, their customs and their material culture, the missionaries unintentionally revealed the nature of the methods they used to gather data. This point in itself is of some importance. On the objective side, these methods involved - though this is never spelled out explicitlylong-term stays on location, participant observation, and random conversations with locals in the vernacular language(s). Since the interviewer was invariably a man, such discussion partners were chiefly, if not all, men. These interviewees were probably mature, of a certain status in their communities, and they were met in a variety of circumstances and venues. Information relating to material life and visible behaviour was arguably the easiest type of data to obtain. Second came details of daily life, as in the last quote.

Historical accounts that were obtained first-hand constitute a valuable record on the auto-history of a particular group, such as in the following quote from Léon Girod in a report he wrote after his first visit, in 1899, to the Nghia-lo region, 120 kilometres west of the town of Yen-bai. Girod offers precious information on customary law, land tenure systems, and the political balance between groups before the arrival of the French as well as at the time of contact. The quote ends with ethnographic details that seem to have been cut from elsewhere and pasted there by a not remarkably skilled editor of Girod's original text:

Prior to the arrival of the Man and Meo tribes, several of whom have come recently, there were only the Thaï and the Muong sharing the country, in well defined divisions known to all. The newcomers agreed

${ }^{5}$ D'Abrigeon, posted among the Man to the northeast of Ha-giang town, in comptesrendus 1901 . 
with the local chiefs who, in return for rewards, allowed them to cultivate the mountains while they reserved the plains and valleys for their own use. But the country was soon to be entirely disturbed by banditry and war, and conciliating the particular interests of the diverse races became a thorny issue. In some areas, the Man, who supported the Chinese, became the masters; in other locations, the Thaï, not happy anymore with their small rewards, forced the Man and the Meo into genuine slavery, requiring them to bear all the burden of public service and forcing them to take care of all the work in their masters' rice fields. Since these unfortunate souls did not obtain French protection against the Thaï, they turned to the Chinese and became their auxiliaries. Due to war, profound changes then occurred to the state of the country, modifications that in time became the new order.

The Meo have no religion; they however believe that spirits return from time to time to the villages; they bury their dead, the only expression allowed being to fire a few gunshots on their parents' grave; the funeral meal exists as everywhere. ${ }^{6}$

Another useful example comes from MEP missionary Pierre Granger quoted in the comptes-rendus of 1902. Granger was posted in Nghia-lo, the mountain hamlet first visited by Girod three years earlier. This sample supplies a wealth of data on the political hierarchy amongst different groups, the politics of dealing with the colonial army, as well as the difficulties for the missionary trying to gain the trust of his hosts:

The Mèo, driven out of Yun-nan by the Chinese, were forced to disseminate across the mountains of Upper Tonkin, but there they found that the valleys and fertile plateaus were already occupied by the Thay and the Man. They were thus forced to look to make a living in the forests. The Méo race is divided into four or five large families all speaking the same language, though distinct from one another in their customs and the colour of their clothes. They form five important villages around Thu-Lê, where they came to settle about 30 years ago. At first, a few Chinese already inhabiting the region stepped forward to be recognized as their leaders, but soon their abuses triggered the most violent reactions of hatred, and they were all slaughtered on the same day by their subjects. Authority was then passed on to a Thay, nonetheless a tyrant like his predecessors, until the day when the French, to cut short additional difficulties, proclaimed the independence of the Mèo and appointed leaders from within their community. Then all hostilities stopped and their submission was sincere.

In my opinion, the military have slightly overestimated the Mèo race. Officers surrounded by soldiers found a warm welcome everywhere. Such is not the case for the individual visitor who has to gain their sympathy

${ }^{6}$ Girod, in comptes-rendus 1899-1900. 
with countless gifts. The Mèo are very hospitable among themselves, visit one another often, eat, drink, smoke in each other's house, and depart without greetings; such is their politeness. Grandparents, children and grandchildren normally live together in harmony in the same house. Arguments are rare, though quite serious when they occur. Quarrellers speak only of severing heads and throwing their enemies' corpses to the river, and sometimes translate their threats into action. They are very superstitious and see spirits everywhere. At the slightest sign of illness, the sorcerer, an important man in the tribe, is summoned. He blindfolds his eyes, hits a drum while tossing around until the spirit enters him; he then lies on the ground to listen to the request. If the illness is benign, he falls on the ground after only a few minutes, and the spirit is happy with the sacrifice of a rooster; if the illness is severe, a buffalo could sometimes be required. The sacrifice is conducted at once, all gather, eat and drink, and the spirit has to be satisfied.

The Mèo believe that after death something remains that does not die, but they do not know what that may be nor where that entity goes; they do not even ask themselves such questions. ${ }^{7}$

In this quote, the last sentence seems to suggest that either the author or the person who edited his original text chose to focus on a matter bearing possible connections with the Christian faith, only stopping short of calling "something that remains after death" a soul. Arguably, such a suggestion could harbour an intent to use this type of similarity to prop open a door for conversion by the resident missionary.

Characteristically, these three selected examples show the ethnographic nature of the missionaries' observations, all made on location. Dispersed throughout the vast body of literature that constitutes the yearly comptes-rendus, these remarks yield information on the political relationships between groups, their oral histories, the internal balance of power between families and across genders, on their economy, rituals, beliefs, and so on. Even fragmentary and partial, this record from a century ago constitutes a valid contribution to the study of these societies.

But on the whole, the data contained in the comptes-rendus are often rough, sometimes distorted through the proselytizing prism and intrusive editing, and show signs of the evolutionist prejudice towards the 'savages' which was a widespread moral position in those days. Yet, these texts also bear the mark of men who could have been sensible enough to understand the importance of coming to terms with cultural issues

\footnotetext{
${ }^{7}$ Granger, in comptes-rendus 1902.
} 
in the hope that their efforts at the salvation of souls would some day bear fruit. On the downside, the clear drawback of these ethnographic segments is their disjointedness, their lack of contextualization, and their brevity, all things that reflect the peripheral interest that a number of missionaries had in matters outside their specific needs of survival, administration, and conversion. However, they also reflect the Bishop's editorial insensitivity to or disinterest in such matters when putting together the final version of the yearly accounts. Had the original letters from each missionary been salvaged, we could possibly tell a significantly different story today.

\section{Religious Publications}

From time to time, accounts of life in the mission found a way into the open domain through one of the popular religious publications put together by the Church for devotees back in France. The most prominent ones were Les Annales de la propagation de la foi and Les Missions catholiques, the genesis of which we touched upon in an earlier chapter, and from the MEP in particular, Annales de la Société des MissionsÉtrangères - renamed Bulletin de la Société des Missions-Étrangères de Paris in 1922 - and Missionnaire d'Asie. A large number of members of the MEP attached to Upper Tonkin published one or more pieces in one or several of these outlets.

Inversely proportional to the number of short pieces published in these journals is their scientific value. The broader the audience, it seems, the weaker the pieces, a clear priority being put on the anecdotal. Among the works published in these media that offer some interest, a typical example is Léon Girod's Dix ans de Haut-Tonkin [Ten Years in Upper Tonkin], a personal account of his work presented as a narrative describing his movements, discoveries, 'adventures', and reflections between 1886 and 1897. ${ }^{8}$ Initially published in sections in Les Missions catholiques, the complete manuscript was later put together as a book in response to keen readers in France who wished to promote Girod's work and with it, the missionary effort in Tonkin. Halfway between travelogue and day-to-day depiction of the feats inherent to missionary life in the outback, Dix ans de Haut-Tonkin is one of the earliest missionary

\footnotetext{
${ }^{8}$ Girod, Léon. Dix ans de Haut-Tonkin. Paris: A. Mame et Fils, 1899.
} 
accounts of the region. As a narrative, it closely follows the events surrounding the gradual colonial take-over of highland Tonkin. As a grassroots level testimony on the expansion of the colonial state into the northern mountains, Girod's text is a valuable source of information. The style exemplifies the usual format, ambience, moral posturing, and populist discourse, especially in the pieces that were published in religious journals for which edifying and entertaining the readership in France was a chief concern. The format is that of storytelling in the first person unfolding in a linear fashion through time as in a diary. As ethnography however, sadly, it has a minor input as it touches only occasionally on the populations living in the region Girod visited. Descriptions of material culture, costumes or architecture in highland societies are brief and limited to the picturesque, stressing for instance a similarity with a feature well known in France - an Alsatian apron, a famous Provence landscape - or pointing at especially surprising, even comical peculiarities - the use of live glow-worms as head-dress decoration.

Girod's contribution exemplifies that as sources of ethnographic information, texts published in missionary journals are above all of contextual value. They circle around the subject rather than address it. They inform about the authors' lives, their whereabouts, and the conditions under which they worked. On the local populations, they provide the odd detail of who was living where and at what time, which is only of value when the identification of 'who' is actually accurately made. Very little transpires about the actual daily life of local populations whose existence and conversion had at least partly triggered the production of such texts. Critical analysis is totally lacking, as are detailed descriptions considered too tedious or perhaps even too shocking for the average reader. On the other hand, problems of missionary life are depicted boldly, especially those relating to the material conditions of work among the natives. Typically, the political situation which undoubtedly had an impact of those conditions is left out. In fact, here, politics are totally absent, largely due to the fact that the religious establishment considered it to be unsavoury to mix the spreading of the word of God with the exactions of the secular leaders - especially when unsympathetic to the missionary project.

Over time, the key themes that were addressed in the popular religious publications coming from mountainous northern Vietnam evolved. They had started with accounts of path-breaking journeys through unknown territories, examples of which include another of Girod's contributions, 
an account of his journey to the northwest of Lao-kay, as well as JeanMarie Martin's account of his travels to Laos. As missionary installations unfolded, this opening theme gave way to pieces by sedentary missionaries in their postings, aimed at describing for the first time an 'unknown' population, such as Théodule Brisson's description of the Lac-thô region. Then, with the accretion of knowledge, more specific issues could eventually be examined, such as a portrait of a highland revolt leader, as described by Paul Figuet. Finally, with the end of the explorations in the highlands and the completion of the cataloguing of tribes dwelling in the Upper Tonkin vicariate, the dominant mode turned blander and became chiefly entertaining storytelling, exemplified by D'Abrigeon's light description of a Meo feast in Les Missions catholiques, a contribution to a series of 'postcards' aptly labelled Scènes de la vie Tonkinoise. ${ }^{9}$

\section{The Spegial Case of ANthropos}

At the end of Chapter 3, I mentioned the creation of the academic journal Anthropos in 1906, a journal that has been publishing the ethnographic work of Christian missionaries ever since. In this section I return to this publication, to examine the most qualified contributions to highland ethnography in and around Upper Tonkin published by early MEP missionaries. These texts deserve closer scrutiny.

The academic journal Anthropos - an 'International Review of Ethnology and Linguistics' - was launched by Austrian priest Wilhelm Schmidt of the Society of the Divine Word, a Catholic missionary society established in Holland in $1875 .{ }^{10}$ Anthropos all at once offered a credible tribune to missionaries who harboured a more specialized interest in learning and communicating about the cultures and languages

\footnotetext{
${ }^{9}$ Girod, Léon "Une tournée dans la région située au N.-O. de Lao-Kay," Les Missions Catholiques, pp. 472-75; 481-90; 497-500; 510-15; 526-28; 533-37, 1902; Martin, Jean-Marie. "Relation sur le Laos' (including a map)," Les Missions catholiques, no. 1560 ss., 1899; Martin, Jean-Marie "Au Laos, Song Ma, Song Dhiel," Les Missions catholiques, no. 1582-1586, 190; Brisson, Théodule. "Le Lac-thô, étude," Annales de la Société des Missions étrangères, nos. 28-29, 1902; Brisson, Théodule. "La propriété chez les peuplades du Lac-thô," Revue Indo-Chinoise, no. 7, 1904; Figuet, Paul-Pierre-Marie. "Un extraordinaire chef de révoltés," Annales de la Société des Missions étrangères, no. 28, juillet-août 1902; Pierre D’Abrigeon, "Un bal chez les Méo," in Les Missions catholiques (1919), pp. 378-9.

${ }^{10}$ It received canonical approbation in 1901.
} 
of the peoples who they had been assigned to convert. By contrast with popular religious journals we have just seen, thanks to Anthropos, the missionaries' prose could reach beyond the limited readership of their superiors, family and fellow Christians back home. Instead, the target reader became anyone on a spectrum that ranged from keen amateurs to professional anthropologists and a number of adjacent academic disciplines (history and linguistics in particular) with an interest going beyond Asia.

By today's academic standards, articles published in the early issues of Anthropos were sometimes of uncertain scientific worth. In principle the editor gave priority to publishing texts written by missionaries in the field around the globe. The new outlet appealed to the well organized and more intellectually prepared among the self-taught ethnographers within the missionary crowd, despite the fact that a vast majority of them had never been professionally acquainted with ethnology, linguistics or history. All the same, the scientific quality of the pieces printed in the early issues was noticeably higher than what appeared in the MEP comptes-rendus or in the missionary journals during the same period.

After the launch of Anthropos, a few capable priests from the MEP sent their texts to this new Catholic channel of scholarly diffusion. ${ }^{11}$ In fact, within the first seven years of the journal's existence, three MEP members stationed in the uplands of Indochina and Southwest China, namely Antoine Bourlet, Aloys Schotter and Alfred Liétard, published a combined total of nine articles, all worthy of attention.

The inaugural issue of Anthropos in early 1906 includes a contribution by the MEP missionary Antoine Bourlet (1874-1952). First posted in Hanoi for his training, he had been moved to the southern part of the West Tonkin vicariate in 1901, in the same year that it became the autonomous Maritime Tonkin vicariate. Sent to the highland portion of that vicariate, Bourlet found himself in Tai-speaking country, in the remote hamlet of Hoi-xuan on the Ma River. ${ }^{12}$ The geographical situ-

11 To prompt potential authors, the Anthropos staff had designed a general structure to be followed by prospective authors which they distributed widely (pers. communication, Yves Goudineau, 2006); unfortunately I have not been able to find a copy of it.

${ }^{12}$ A reflection of the imprecision on the frontier zones at the time, as well as the overlapping jurisdictions between the customary, colonial, and religious territories, Hoi-xuan was attended by a missionary from Maritime Tonkin even if on paper, the region was part of the Laos vicariate. In fact, in all his writings, Bourlet situates his field location and the populations he writes about within the Tai muang of Hua Phan 
ation of Hoi-xuan would suggest that the Tai speakers there were Thai Daeng, Red Thai, although the missionary never used that name. The following year, Bourlet was to publish three more pieces in Anthropos plus a final one in 1913, a total of five articles that made him one of the most prolific contributors to the journal at the time.

In these articles, Bourlet addresses the Thai culture that he encountered during his posting, which he calls 'Thay'. His earliest piece, published five years after his arrival, had already risen above the simpler standards of missionary discourse by explicitly presenting such specialized features as the 'Thay' political organization, the land tenure system, and the agricultural economy. The term the author chose to describe the 'Thay' social system as a whole was 'socialism' - though no precise reference was made as to what he meant exactly by that notion nor how it related to its namesake political ideology.

His next three contributions form one coherent piece of ethnography of the 'Thay', split over three successive issues of the journal and totalling 58 pages adorned with 27 photographs, presumably taken by the author himself. ${ }^{13}$ The scope of Bourlet's project was wide. At the start, he described its structure as being "as simple as it is natural". ${ }^{14}$ So simple and natural in fact, that he felt no need to look into the works of others for a model or a justification, or if he did, he declined to let his readers know about them. His 'natural' structure first touched on "Intimate life" which here meant family life, by far the largest section with details on architecture, gendered roles, education, childbirth, marriage and divorce; secondly, "Public life" or relations with the chiefs, with details on power hierarchy, prerogatives of the chiefs, corvées and taxation; thirdly, "Religious life", or relations to the supernatural, with explanations on the cults of spirits and the dead, induced illness, divination and cure, ritual calendar, dreams; and finally, "Origins according to myths and legends" presenting an emic understanding of the origins as

\footnotetext{
Thang $H_{o c}$, a vast mountainous domain today split between the provinces of Hua Phan in Laos and Thanh Hoa-derived from Thang Hoc - in Vietnam.

${ }^{13}$ Bourlet, Antoine. "Socialisme dans les hua phan (Laos, Indo-Chine)." Anthropos, vol. I:87-94, 1906; Bourlet, Antoine. "Les Thay: I. Vie intime du Thay, sa famille." Anthropos, vol. II, no. 3, pp. 355-373, 1907a; Bourlet, Antoine. "Les Thay: II. Vie publique du Thay, les rapports avec les chefs; III. Vie religieuse du Thay." Anthropos, vol. II, nos. 4-5, pp. 613-632, 1907b; Bourlet, Antoine. "Les Thay: IV. Origine des Thay d'après les mythes et légendes." Anthropos, vol. II, no. 6, pp. 921-932, 1907c.

${ }^{14}$ Bourlet, "Les Thay: I. Vie intime du Thay, sa famille," 355.
} 
it had been embedded in the indigenous cosmogony. These three 1907 pieces also include a brief consideration of the 'Thay' language and script in which distinctions are made between the script as observed by the author and the script of the Lao Tai dominant in neighbouring Laos. However, instead of listing comparative vocabulary between these two languages, which would have been in tune with the common practice at the time, Bourlet shows evidence of a more systematic mind by presenting the complete 'Thay' and Lao alphabets. He includes a column detailing the tones in a quốc ngũ transcription - the Romanized Vietnamese script - thus showing a good command of yet another alphabet. Based on linguistic deductions, Bourlet concludes that these 'Thay' are a sub-group of the Lao, though he notes many similarities between 'Thay' and Siamese unknown in the Lao language, providing interesting clues with which to analyze migratory trajectories. ${ }^{15}$

Finally, in 1913, Bourlet followed up these four earlier works with a few pages that completed his ethnography of the 'Thay', in particular observations of funerary rites left out of the earlier pieces. I suspect that this later text was actually written at the same time as the earlier ones, as its fashion is similar and shows no sign of additional intellectual maturation or any significant change in the substance and style of the discourse compared to 1906 and $1907 .{ }^{16}$ Why it only got published six years later remains unknown.

His articles show that Antoine Bourlet was one of the most competent MEP highland missionary ethnographers in Tonkin at the time. Unfortunately, little is available about his life that would help us to assess his social and educational background and assist in evaluating the underpinning of his ethnographic writings. He was born in 1874 in a small town close to Clermont-Ferrand, probably in a rural family, was educated locally, and moved up the ecclesiastical ladder in the normal way. He arrived in Tonkin in 1898 after two years at the MEP seminary in Paris, then learned Vietnamese for a year in Ke Sở before his assignment to Hoi-xuan. In his articles, nothing filters out about himself except perhaps the hint of an well-read background revealed by a charming and at times poetic hand combined with clarity in the discourse, which makes his manuscript concise, pleasant to read, and

15 Bourlet, "Les Thay: IV. Origine des Thay," 931. 1913.

6 Bourlet, Antoine. "Funérailles chez les Thay." Anthropos, vol. VIII, pp. 40-46, 
devoid of superfluous missionary references and intrusions. Arguably, these qualities bring Bourlet's text closer to contemporary ethnological academic standards. Yet, Bourlet was a self-taught ethnographer who learned the basics of ethnology in the field as a means of proselytizing more effectively. Though well constructed, his ethnography remains descriptive with no significant attempts at discussing practices or analyzing behaviours. References to other authors are absent. Presumably destined since his arrival to the task of conversion of the Tai speakers on the fringes of the mission, he may have been introduced to Tai language by some of his MEP colleagues previously active in Siam (hence his knowledge of that language and script) while he probably learned the vernacular language among his converts. Amid the normal and expected performance of his predication, Bourlet somehow must have found the drive to justify devoting time and energy to conducting and publishing his research on the people with whom he was in touch in ways that exceeded the normal expectations of his religious establishment. Was this curiosity? Could he have been prompted into this by individuals associated with Anthropos? We cannot answer this question.

Second on our list of early MEP contributors to Anthropos comes Aloys Schotter (1857-1924) who spent 43 years in China. A French Alsatian who spoke French and German equally well, he was posted in the district of Hin-y-fou in the southwestern Chinese province of Guizhou. In MEP's hands, the vicariat du Kouy-tcheou was managed from the China See and had no direct administrative connection with Indochina. But even if situated north of Tonkin in the Southeast Asian massif, many of the same ethnic groups as those dwelling in the Tonkinese segment of the massif could be found there. Living conditions were comparable, intellectual influences followed the same channels. We can assess from his writings that Schotter's methods were similar to those of his Upper Tonkin colleagues.

Like Bourlet, Schotter is a minor historical figure with little available on his life prior to joining the MEP. We know that his parents were peasants and regular readers of Annales de la Propagation de la Fo $i$ which contributed to the three younger among the four Schotter brothers joining the MEP and going to China, where they all ended their lives and were buried. As a young adult, before joining the seminary in Paris, young Aloys taught in various locations in France. On his intellectual abilities, his MEP obituary said of him: "He liked education. $[\ldots]$ He nurtured all his life a taste for studies and intellectual work. He was always working on some project, sometimes several, or pondering 
over some idea." His brother Alphonse was also described with similar fondness. From a modest family background, the Schotters had visibly grown to become intellectually alert. ${ }^{17}$

One can appreciate from his texts that Aloys Schotter must have had a solid enough educational background to make him confident that he could embark on ethnographical surveys, produce well-built texts, and have them accepted for publication in more significant outlets than the easy going missionary journal. In 1908, 1909, and 1911, Schotter, then in his 50s, published three related ethnographic articles on the Miao, one of the main highland groups of Guizhou. In total, this contribution amounts to 89 pages including a few photographs. The trilogy was explicitly meant to be the first part of a contribution planned to be significantly longer, as he wrote that these later articles would include a survey of two other groups, the Y-jen (a Tai-speaking group) and the 'Old Chinese' (Vieux Chinois) who had come to settle in Guizhou long before the more recent waves of Han migrants. For unclear reasons, the full project did not materialize beyond the Miao trilogy.

Schotter wrote that he earnestly questioned the neophytes from the 'tribes' he wished to study. Because these young men were students in a French mission, it is possible that Schotter conducted his interviews at home and in his native tongue - he does not say. However, Schotter also provides proof in his text that he paid many visits to Miao villages and stayed on several occasions in Miao houses, where he could develop a more genuine sense of Miao life.

These three articles on the Miao bear the same title, Notes Ethnographiques sur les Tribus du Kouy-tcheou (Chine), Ethnographic Notes on the Tribes of Kouy-tcheou, with different sub-headings. It starts with depicting briefly the ethnic diversity of a rugged Chinese hinterland. In doing so, Schotter proposes his personal classification of the peoples of Guizhou, one he states that he discussed with his neighbour and contemporaneous colleague Paul Vial, who "liked it". ${ }^{18}$ It was a brave effort under the circumstances, and a classification not exempt from cultural bias as this introductory statement indeed indicates:

\footnotetext{
${ }_{17}$ MEP Website: http://archives.mepasie.org/recherche/notices_necro.php?nume ro $=1513 \&$ nom $=$ schotter.

${ }^{18}$ Schotter refers explicitly to conversations, either face to face or through correspondence, with his colleagues who had spent a long time in Asia, in particular Vial in Yunnan.
} 
The Miao, like the bushes, cover the rocks of Kouy-tcheou. The Y-jen, such as a mighty trunk, shoot the ramifications of their crowded villages into the fertile plains. The Chinese, like parasite mistletoe, sneak in everywhere, suck, and exploit the aboriginal populations, pretending to govern. ${ }^{19}$

Schotter then proceeds to a detailed description of the Miao. He initially pictures their society in general terms, then presents several subgroups such as the 'Yao-jen', the 'Hong-miao', 'Pë-miao', 'Hë-miao', and various affiliated groups, as well as a number of others which, he believes, had a less sure affiliation to the Miao family. The structure of the text is without surprise, with sections on geographical location, origins, customary law, script and language, as well as character, costume, houses, and marriage, together with funerals, economy, political regime, and religion. However, his categories and subheadings are not consistent from one subgroup to the next, a symptom of the lack of rigour in his methodology when conducting fieldwork inquiries. It also denotes an attempt to make the most of possibly meagre field notes at the cost of introducing inconsistencies in his comparisons.

In his rendering of Miao myths (the Miao as a whole, ${ }^{20}$ then the Hë Miao), ${ }^{21}$ instead of giving verbatim the myths he recorded (the Creation, the Great Flood) Schotter summarizes the narratives and adds a commentary interspersed with short quotes. In this role Schotter shows a fine capacity for scrutinizing the oral text beyond its apparent meaning, but his attempts at deconstructing it are tainted by unconcealed ethnocentric assumptions and his contribution to the early ethnography of Miao mythology loses significance, the original oral text of the myths being lost. The next section, on the feudal system of the Yao-jen, ${ }^{22}$ shows ethnographic qualities with a detailed and enlightening list of the corvées and payments due to the local Landlord for each month of the year, which constitutes an undeniable contribution to the economic history and economic anthropology of that group.

\footnotetext{
${ }_{19}$ Schotter, Aloys. "Notes ethnographiques sur les tribus du Kouy-tcheou (Chine): Introduction." Anthropos, vol. III, pp. 397-425, 1908, 403.

${ }^{20}$ Ibid., 419-25.

${ }^{21}$ Schotter, Aloys. "Notes ethnographiques sur les tribus du Kouy-tcheou (Chine): IIème partie: Les différentes tribus des Miao, chap. 5-9 et Récapitulation." Anthropos, vol. VI, pp. 318-344, 1911, 24-8.

${ }^{22}$ Schotter, Aloys. "Notes ethnographiques sur les tribus du Kouy-tcheou (Chine): II ${ }^{\text {ème }}$ partie: Les différentes tribus des Miao, chap. 1-4." Anthropos, vol. IV, pp. 418-453, 1909, 329-31.
} 
Schotter relied first on his personal observations, second on those of other Catholic missionaries who were part of his network, then on a few Catholic authors, and finally on Chinese texts. In intellectual terms, he used history and linguistics as his main analytical fields. His historical appreciation included oral history collected on location, while his linguistic analysis stands in small sections of vocabulary lists scattered throughout the text. He devotes the rest of his text to descriptive ethnography. ${ }^{23}$ It is a rare and well worth noting element that a missionary in those days, not trained in producing scientific or other scholarly writing, would care to include an explicit section on his sources. ${ }^{24}$ It is in the initial pages of his first article that Schotter provides details on the published material he used to support his views. This material is dominated by Chinese historical accounts and provincial annals translated into French that offer an exogenous point of view on the highlanders, mostly a derogatory one, since as Schotter put it, "the Chinese mandarin's scornful dislike cannot but influence his judgment when discussing these non-Chinese barbarians in our province", dragging that mandarin's writing into the realm of "unfortunate wild imaginings". ${ }^{25}$ Unsurprisingly, Schotter's second main documentary source is the writings of his fellow MEP missionaries. From that pool, he uses accounts based on observations in the field as well as his colleagues' translations and interpretations of Chinese texts. Thirdly, his list mentions a few additional works by French, English or German lay scholars. In the course of his three articles, Schotter mentions no less than 30 different authors by name, sometimes with a short quotation, not once with full referencing. Due to his relative geographical isolation, an atavistic reluctance to quote Protestant or Anglican missionaries, or perhaps simply because of a lack of competence in English, Schotter failed to include the most obvious relevant works then available on the Miao in Southwest China, published by missionaries such as Bridgman, Lockhart, Deka, Edkins, and Crawford. ${ }^{26}$ Adding to this shortcoming

${ }^{23}$ Ibid., 418-9. Schotter, "Notes ethnographiques [II ${ }^{\mathrm{ème}}$ partie]" vol. IV, 322-4, 346-7, 349, 353; Schotter, "Notes ethnographiques [II" ${ }^{\text {eme }}$ partie]" vol. VI, 328-9.

${ }^{24}$ Schotter, "Notes ethnographiques [Introduction]" vol. III, 403-4.

${ }^{25}$ Ibid., 404, 412.

${ }^{26}$ Bridgman, E.C. "Sketches of the Miau-tsze." Fournal of the Royal Asiatic Society, North China Branch, vol. 3, pp. 257-86, 1859, 257-86; Lockhart, William. "On the Miautze or Aborigines of China." L'Année géographique, vol. 1, pp. 297-306, 1863 297-306; Deka, W. "Spoken language of the Miau-tsze and other aborigines," Notes and Queries 
comes the even more surprising absence from his bibliography of French authors such as Hervey de St-Denis and Gabriel Devéria mentioned earlier, who had also published on the Miao in China. ${ }^{27}$ No doubt aware of his fragile intellectual position, he provided a pre-emptive reply to his critics:

The work I begin here is but an imperfect draft. What could earn me the readers' indulgence is to think that the missionary is more often on the abrupt and wild paths of Kouy-tcheou than in consultation with the learned and scholarly volumes published by ethnographers and philologists. ${ }^{28}$

The part of Schotter's text that revealed the most about why he chose to push his ethnography beyond what his religious leaders expected from him, which by the same token helps us understand his method, comes when he explains that he wanted to contribute to the ethnography of Kouy-tcheou because that province presented an exceptional ethnic diversity, which he expressed in a metaphor - this quote also hinting at his monogenist mindset:

For the ethnographer and the philologist, Kouy-tcheou is a true El Dorado. Nowhere else, I believe, can one find in such a relatively small space such a variety of races. [...] Kouy-tcheou is like a fardin des Plantes [a Botanic Garden], an ethnological museum. Its abrupt mountains and deep valleys form grandiose boxes where, classed and catalogued, grow multiple samples of tribes. These are the survivors of aboriginal races that constituted China's original population before they were pushed back by the Han Chinese invaders. These are the children of the Pre-Chinese; and our Kouy-tcheou is the Pre-Chinese province par excellence. ${ }^{29}$

He then carves another metaphor to describe the religious incentives underpinning his work:

on China and Japan, vol. 1, 1867 131-2; Edkins, J. "The Miau-tsi, their history." China Recorder, vol. 2, 1871; Crawford, T.P. "The Miao-tsz, or Aborigines of China." China Recorder, vol. 10, no. 5, pp. 385-7, 1879, 385-7.

${ }^{27}$ Hervey de St-Denis (Marquis). "Ethnographie des Miao-Tze." Comptes-rendus du Congrès des Orientalistes, vol. 1, pp. 354-63, 1875; Devéria, Gabriel. "Les Lolo et les MiaoTze. A propos d'une brochure de M.P. Vial, missionnaire apostolique au Yun-nan." Fournal asiatique, $8^{\mathrm{e}}$ série, vol. 18, pp. 356-69, 1891. As an interesting quirk of fate, later scholars of the Miao and the Hmong, including scholars writing in French, who surely were the most likely users of early ethnography on these groups, have themselves rarely cited Schotter. This comes as an even bigger surprise given the broad readership and wide availability of Anthropos.

${ }^{28}$ Schotter, "Notes ethnographiques [Introduction]" vol. III, p. 398.

${ }^{29}$ Ibid., 397-404; Ibid., 397-8. 
A peasant does not fear wasting his time in studying the composition of the land that he wants to clear and plough. [...] The study of inhabitants is what interests most the missionary. Ethnological knowledge and the study of the dialects spoken by these tribes prepare their evangelization. Isn't that motley population truly the portion of vine attributed by God to the missionary? It is the close material onto which he must exercise his zeal; it is the land to clear. Properly learned, local dialects will be the instrument of predication needed to transform these pagan populations into Christians. Alone, this consideration should suffice for the missionary to devote his spare time getting to know these multiple races better. ${ }^{30}$

These quotes and others strongly suggest a heartfelt engagement by Schotter with the peoples he proselytized. In fact, save for a few exceptions, his text is remarkably exempt of the rampant ethnocentric commentary that is associated with missionary prose most of the time. A rarity at the time.

To close our examination of the earliest MEP contributors to Anthropos who were posted in the Mainland Southeast Asian massif, we now consider the case of Alfred Liétard (1872-1912), based in Yunnan for 16 years before his premature death at age 40. With disappointingly little known about his background, combined with a surprisingly important and competent ethnographic production, Liétard remains an enigma. On his youth, nothing seems to have been recorded except that he was born in Vieux-Condé, a French mining town on the Belgian border. Unusually, he did all his religious studies at the MEP seminary in Paris, which he entered in 1891 at age 19. Where and what did he study prior to that year? We may never know. He was made a priest in June 1896 and was sent to Asia the next month. Liétard was attached to the China branch of the MEP and dispatched to Yunnan. He spent the first two years at the vicariate's See in Yun-nan-sen (today Kunming) to learn Mandarin and help with administrative tasks. In 1898, he is sent on his first posting to Lan-ngy-tsin, a three-day walk east of the See, where he replaced his colleague André Kircher who himself had recently taken over the mission from its founder Paul Vial. There, he proselytized among the Lo-lo A-hi (Ashi, Axi) and weathered the Boxer Rebellion. ${ }^{31}$ In 1904 he was put in charge of the district of Pien-Kio

\footnotetext{
${ }^{30}$ Ibid., 398, 404.

${ }^{31}$ From the end of 1899 to September 1901, this major uprising targeted foreign interests and agents in China, in particular Western Christian missions and local converts. A large international expeditionary force was eventually dispatched to quench it and a Peace Agreement between foreign powers and China was signed on September 7, 1901.
} 
farther west in Yunnan, just east of Tali Lake, which he reached in 1905. He worked in particular among the Lo-lo p'o in the village of Djo-kou-la on the Yangtse, two days north from Pien-Kio, and developed sympathy for them which was not appreciated by the local mandarins; he eventually had to leave that region. In 1908, after completing a Lo-lo grammar book (A-hi dialect), he was given responsibility of the district of Pin-Y in eastern Yunnan. Over the two years he spent there, Liétard preferred to be posted in the native village of Pe-Che-Ngay instead of Pin-Y, the head town. He was again recalled from that posting in early 1910 to be sent to Tchen-Fong-Shan. For an unknown reason, he was quickly redirected to the busy northeastern district of Tchao-Tong (today Zhaotong). A violent fever took his life in July 1912 and he was laid to rest in his mission.

During his postings Liétard observed a variety of local populations and devoted special attention to Lo-lo groups known in China today as the Yi. We will soon come back to Liétard's writings on the Lo-lo. For now, it is another population, one he called the 'Min-kia', that we will address as it is the one about which he wrote a 28-page article published by Anthropos in 1912, titled Au Yun-nan, Min-kia et La-ma jen. ${ }^{32}$

Liétard became acquainted with the Min-kia and the La-ma jen during the years he spent in the Tali region between 1905 and 1908. He acknowledges that he could not study these two groups as well as he had wished to, having been reassigned to another mission just when he was starting his more serious work on them. In this article, the central question he addressed was: To which other "ethnic groups"-interestingly, he does not use the term tribes - are the Min-kia related? Searching for an answer to this question, Liétard divided his article evenly between ethnography and language analysis. In the first section he supplied details about Min-kia history and geographical location. The brevity of his notes on their economy, costume, and religion, suggests a lack of familiarity with their daily life, a hypothesis that the absence of details on data-collection methods compounds further. Liétard devoted the other half of the paper to Min-kia vocabulary and lexical examples, comparing these with French, Chinese, 'La-ma-jen', 'Mo-so', 'Li-sou' and 'Lo-lo' languages - a feat in itself! His method to support this tentative classification of the language spoken by the Min-kia was to use Chinese data contained in numerous French language sources ranging

${ }^{32}$ Liétard, Alfred. "Au Yun-nan, Min-kia et La-ma jen.” Anthropos, vol. VII, pp. 677-705, 1912a. 
from Marco Polo to Francis Garnier ${ }^{33}$ and MEP colleague Paul Vial. ${ }^{34}$ Wrapping up his linguistic analysis, Liétard concluded that he had not successfully achieved his goal of positively classifying the Min-kia.

Uncharacteristically, in his sources, Liétard puts no special emphasis on religious and missionary texts. Even more remarkable when compared to his colleagues, including those who like him published in Anthropos, is the proper referencing he makes of his sources and the intellectual honesty he displays in using their works and ideas. Liétard explicitly quotes letters from colleagues whom he consulted and acknowledges their contribution very precisely. In this sense, although not contributing with this article a weighty ethnographic piece, Liétard appears to herald the end of an era and prefigure another, more systematic one.

Liétard himself provides us with an exemplary transition piece into that new era, a 280 page monograph on the Lolo based on four years of residence among the Lo-lo p'o, which we will examine in the next chapter along with the works of two other MEP ethnographers of the new intellectual generation, Paul Vial and François Marie Savina.

33 Garnier, Francis. Vyage d'exploration en Indo-Chine. Tome II. Paris: Librairie Hachette, $1873 \mathrm{~b}$.

34 Vial, Les Lolos. 


\section{CHAPTER EIGHT}

\section{THE WORKS OF MISSIONARIES LIÉTARD, VIAL, AND SAVINA}

As far as the ethnography of highland Southeast Asia goes, here we have a remarkable trio. Paul Vial (1855-1917) arrived in Asia in 1881, Alfred Liétard (1872-1912) 15 years later in 1896, and François Marie Savina (1876-1941) another 5 years after again, in 1901. The three MEP missionaries were therefore simultaneously posted in the Southeast Asian massif between 1906, when Savina received his first assignment in highland Tonkin, and 1912 when Liétard passed away. It is certain that the three knew of each other, and Liétard and Vial met on numerous occasions, having been posted for a few years in neighbouring missions among the Lo-lo in the Yun-nan vicariate. In all likeliness, the three men knew also of each other's work and writings. Vial, the elder, started a long series of publications in Les Missions Catholiques in 1888, read by all MEP colleagues; Liétard got his first piece published in that same medium in 1903; and Savina published his Tay dictionary, his first opus, in 1910 in Hanoi. It is the aim of this chapter to trace the scholarly connections between these authors and examine their work critically.

\section{Alfred Liétard and Paul Vial among the Lo-lo}

At the periphery of Upper Tonkin in the Mainland Southeast Asian massif, lies the southwestern Chinese province of Yunnan, where millions of representatives of the same or closely related highland societies as in northern French Indochina dwell. Following an ancient missionary establishment in neighbouring Sichuan, Yunnan, which was made a vicariate in 1696 but only obtained its administrative autonomy in 1843, saw Catholic missions being set up by the Société des Missions étrangères de Paris throughout the 19th century. By the early 1870s, Latourette reported that there were 8,000 Catholic converts in Yunnan supported by an undetermined portion of the 78 European missionaries that the MEP sponsored in China as a whole. MEP historian Adrien Launay stated with more precision that by 1889 , the "Yun-nan" vicariate had 
one bishop, 25 missionaries, 7 indigenous priests, 53 churches or chapels, one seminary, 60 schools or orphanages, and 10,221 converts. ${ }^{1}$

By the turn of the 20th century Alfred Liétard and Paul Vial were prolific producers of ethnography among the MEP in Yunnan. Both interested in the Lo-lo tribes, the majority indigenous population there, their work was closely related. Yet, it remained intellectually distinct.

Alfred Liétard's scientific works were all published between 1909 and 1913. He first released a few articles on Lo-lo languages in academic journals, followed by the piece on the Min-kia and La-ma-jen in Anthropos we examined briefly in the previous chapter. In terms of his more substantial pieces of work, there were two: his Essai de dictionnaire LoloFrançais reproduisant le dialecte parlé par la tribu des 'A-Hi'. Suivi d'un vocabulaire Français-Lo-lo (A-Hi) [Tentative Lolo-French dictionary reproducing the dialect spoken by the 'A-Hi' tribe, followed by a French-Lo-lo lexicon] published in 1912, and his major ethnography, Au Yun-nan: Les Lo-lo p'o. Une tribu des aborigènes de la Chine méridionale [n Yun-nan: the Lo-Lo-p'o. An aboriginal tribe in southern China] published in 1913. ${ }^{2}$

Liétard's Essai de dictionnaire Lolo-Français is a slightly edited compilation of his earlier language articles published in the BEFEO (Bulletin de l'École française d'Extrême-Orient) and T'oung Pao between 1909 and 1912. The book is wrapped around a 97-page core, a Lo-lo-French dictionary, while the rest touches on details of the grammar and syntax of the Lo-lo A-Hi language. Throughout the book, little transpires on the author's methods and intentions other than it being an obvious attempt to help future missionaries to work better among the Lo-lo. One can also perceive evidence of a long proximity with Lo-lo speakers embedded in numerous comments, remarks, and precisions given on particular

\footnotetext{
${ }^{1}$ Latourette, Kenneth S. A History of Christian Missions in China. London: Society for promoting Christian Knowledge, 1929. Pp. 323, 327. Launay, Adrien. Atlas des missions de la Société des Missions Étrangères de Paris. Lille: Desclée, de Brouwer et Cie, 1890. We could add that British traveler George Morrison reported that in 1894 there were in the Yunnan vicariate, 22 French missionaries, 8 native priests, and 15,000 Catholic converts. Morrison, George E. An Australian in China. London: Horace Cox. 1895, p. 171. For a history of the early years of the Yunnan vicariate from 1843 to 1903, see Maire, Edouard. "Mission du Yunnan. Traditions et souvenirs. Bulletin de la Société des Missions-Étrangères de Paris, vol. 1. Pp. 10-16, 48-55, 70-76, 134-142, 206-215, 346-355, 403-410, 524-533, 592-603, 651-661. 1922.

${ }^{2}$ Liétard, Alfred. Au Yun-nan: Les Lo-lo p’o. Une tribu des aborigènes de la Chine méridionale. Münster: Aschendorffsche Verlagsbuchhandlung, Anthropos Bibliothek, 280p. 1913a; Liétard, Alfred. Essai de dictionnaire Lolo-Français reproduisant le dialecte parlé par la tribu des A-Hi'. Suivi d'un vocabulaire Français-Lo-lo (A-Hi). [Extracts from T'oung Pao vol. XII \& XIII]. Leide: E.J. Brill, 1913b.
} 
terms or syntaxic peculiarities. In terms of substance, as is the case with any language dictionary, information of an ethnographic nature is thus peppered throughout in the form of contextualised examples for entries such as those relating to terms of address, religious vocabulary, agricultural terminology, material culture, and so on. Beyond that obvious, yet indirect worth as an ethnographic source, the genuine value of this book for anthropology remains understandably limited.

We have quite a different picture with Au Yun-nan. This substantial 280 page book published posthumously constitutes a genuine contribution to the ethnography of that minority group with whom Alfred Liétard had lived in close contact for several years. It is in his short preface and in the introduction to Part 4 that the priest explains why he wrote the book. Having received letters from "several French scholars I consulted"3 who noted that the Lo-lo of Yunnan and their languages were insufficiently well known, he decided to disseminate the knowledge he had acquired on that group.

Liétard explains that the first step in his endeavour was to gather all the published material he could find on the Lo-lo in order to be able to quote them as much as possible, but also to criticize them when appropriate. He says:

I would like to avoid the trap many explorers fell in, whom, having only observed one or two particular tribes, described the Lo-lo in general from the sole tribe they had studied, and thus committed rather big mistakes. ${ }^{4}$

He divided his book in four parts. Part 1 covered 'Name, division and distribution of the Lo-lo' (pp. 1-50), Part 2 focused upon the 'Physical life of the Lo-lo' (pp. 51-104), Part 3 examined the 'Spiritual life of the Lo-lo' (pp. 105-194), while in Part 4 he turned to examine the 'Language of the Lo-lo-p'o' (pp. 195-272). His aim, explained in the very short introduction to Part 2, was to write on one particular group of the Lo-lo, the Lo-lo p'o. Candidly, he added: "may this study be of use to science, and may it allow the reader to better know this people that I love. That is my only aspiration." 5

The first three parts form a logical body of general ethnography, while Part 4 is chiefly constituted of a grammar and lexicon. In Part 1,

${ }^{3}$ Liétard, Au Yun-nan, 195.

Ibid., 51.

${ }^{5}$ Ibid., viii. 
Liétard critically compares the information published by various European and a few Chinese authors against the information he himself collected, either first hand or through MEP colleagues he was in touch with. He discusses terminology - Man-tse vs. Y-jen, Hé-y vs. Pé-y, Hé Lolo vs. Pé Lo-lo, Hé kou-t'eou vs. Pé kou-t'eou, etc. - and the geographical location of the group in the provinces of "Seu-tch'ouan" (Sichuan) and Yun-nan. As such, Part 1 thus proposes a taxonomic overview based on a review of the literature mixed with personal observations. It is this section where the largest number of references is made to others' publications.

Parts 2 and 3 constitute the main body of the ethnography. In the former, Liétard exposes facts relating to the physical and material life of the Lo-lo including their origins, morphology, physiology, psychology, food culture (food, cooking, tobacco), architecture (village, house), livelihoods (division of labour, plants cultivated, tools, alcohol and oil production, livestock, hunting and fishing), clothing and ornaments for men and women, and industry and commerce (tools, hemp, weaving). His heftier part three addresses the Lo-lo spiritual life and opens with sections on games and entertainment (for children and adults, dance, music), and poetry (songs transcribed from Lo-lo but also translated into French). Next comes religion with a detailed exposé on the cult of Heaven, the heavenly messenger, the cult of the ancestors and their ritual representations, ghosts and superstitions, male and female 'sorcerers', divination, magic, temples, myths, and legends. Details regarding feasting among the Lo-lo p'o follows, with a list of yearly, sacred events and a description of the main ones (New Year's pig, the ancient Lo-lo New Year, the Lo-lo p'o New Year, feasts of Chinese origins, the stuffed-bread feast, the torches feast, the ceremonies of the dead, ceremonies of cakes and of the new harvest). Next comes a section on family which relates primarily to marriage (pre-marriage, the wedding, wedding songs, conjugal practices among the Lo-lo p'o and more broadly in the Tali area, intermarriage, polygamy, birth, names and surnames among the Lo-lo p'o). The penultimate section covers illness and death (funerals, the widow's lament, the daughter's lament at her mother's deathbed, the otherworld), while the last part addresses social life (life within the household, social organization, political leadership, social organization among the Lo-lo of Sichuan). Part 3 ends with a short, critical epilogue on the probable fate of the Lo-lo facing Han expansionism and assimilationism.

Part 4, finally, is an 85-page lexicon and grammar of Lo-lo p'o language which Liétard divided into 13 sections touching on anything from 
phonemes to tones, syntax, conjugation, and script. There is no general conclusion to the book; presumably, a one-and-a-half page epilogue found in part three might have been meant to serve that purpose. In terms of iconography, overall there are only a few basic drawings in the material life section, one traditional Lo-lo musical score in the song section, and regrettably no maps nor photographs. A reference list is absent, some referencing information lying in footnotes.

Liétard explicitly calls his work ethnography. He apologizes for not being able to provide accurate anthropomorphological measurements, missing the necessary tools and, presumably, the knowledge. ${ }^{6}$ On history, he is definitely not at his strongest, with his main references coming from Tien-hi (a Chinese source), Sainson, Du Halde, Rocher, or Cordier while elements of oral history are also collected and presented, which reinforce this section. It is arguably in the section on religion where the author's highest interest lies as Liétard endeavours to present not only Lo-lo religion, but also to correct mistakes made by several of his scholarly predecessors, namely Legendre, Baber, Leclère, and Du Halde.

Another noteworthy characteristic of the book is that like his 1912 paper presented above, it is nearly totally devoid of Biblical references and ethnocentric remarks. ${ }^{7}$ For instance when he reports the Lo-lo myth of the Great Flood, there are none of the tempting references to the Old Testament which practically all missionaries fail to refrain from mentioning, nor does such a reference crop up later. ${ }^{8}$ On the other hand, Liétard's objectivity does not go as far as to absolve the Chinese from the sins of greed, brutality, even "utmost cupidity" against the nonHan: "The very rare [cultural, economic] breeding with the Chinese are far from contributing to elevating the intellectual or moral level!" 9 On the whole, however, Liétard's relative absence of bias compared to his missionary colleagues, relates at least in part to Yunnan not having been colonized by Europeans. This meant that adapting to the local customs, developing sympathies with the natives, and conversely, criticizing the oppressive Chinese state with them became more desirableand politically astute - tasks.

Regarding his intellectual affiliation, Liétard remains consistent with his 1912 article in Anthropos and shows an uncommon degree of transparency. More explicitly than any of his colleagues, he acknowledges his debt

6 Ibid., 60.

Bar one, p. 192.

8 Liétard Au Yun-nan, 140-142.

9 Ibid., 192 \& 67. 
on numerous occasions in the book, in particular to one of his MEP colleagues, Joseph-Eugène Martin. Martin was posted for 18 years among the Lo-lo of southern Sichuan and, according to Liétard, was an immensely competent, though modest ethnographer who never wished to publish his notes. Letters that Martin sent to Liétard are quoted at length time and again in the book, and duly acknowledged. The same can be said of shorter exchanges he had with other colleagues, some of whom he mentions by name (Vial, Ponsot, Kircher, Gorostarzu, Maire, Badie, Monbeig, Perny, Legarrec). A sampling of his twenty or so published sources includes scholars (Henri Cordier, Gabriel Devéria, Paul Pelliot, Alexandre Chavannes), explorers (Rocher, D'Ollone, D’Orléans), officials and military officers (C. Sainson, Auguste Bonifacy, Jean-Baptiste du Halde). The only Chinese source openly mentioned is the Tien Hi but it would be surprising if Liétard had not also used other Han authors or even English speaking ones. Finally, the source for the structure of the book remains unexplained.

We can assert that Liétard's methods have definitely yielded a more solid, dependable, and scientific result than what could have been expected from a standard religious education received in Paris towards the end of the 19th century. The fact that he published comparatively little in popular missionary journals, and chose instead to devote his short adult life to more scholarly pursuits suggests a man with a vision and possibly, at the source of it all, a man with an intellectual background of good standing. His ethnographic work is still read and quoted by anthropologists of inner Asia today. Even in his lifetime, his intellectual standing did not go unnoticed. In May 1912, his dictionary earned him a significant academic distinction, officier d'Académie, awarded by the ministry of Public Education in France. When he passed away, Father Schmidt, founder and editor of Anthropos, said of Liétard: "Ethnological and linguistic sciences are at a sizeable loss with the death of this dedicated missionary, gifted with an uncommon capacity for the faithful and objective observation of facts." ${ }^{10}$ Considering the very short productive life of the man, with only four years separating his first scientific publication from his death, this turns out to be a remarkable achievement.

$$
\text { * } \quad * \quad *
$$

\footnotetext{
${ }^{10}$ Preface in Liétard, Au Yun-nan, viii.
} 
Addressing the case of Alfred Liétard first despite his published work coming out after that of Paul Vial, constitutes a useful exercise before moving on to his older colleague. This arrangement will help us see that Vial's life and writings prove that he was simultaneously a better, and a worse ethnographer than his younger colleague.

Born in 1855 in Voiron, $25 \mathrm{~km}$ north of Grenoble (Isère), the fifth of eight children, young Paul Félix Angèle Vial first studied with the Jesuits in Avignon from 1868 to 1874 . He had resolved to permanently join the Society of Jesus but into his novice year, he was dismissed by his directors. He turned to the Missions Étrangères de Paris whom he joined in 1876. Ordained priest in September 1879, he left for China in October and reached Yunnan via Sichuan six months later. His first year in the Yunnan vicariate was spent learning Chinese in Long-ki (today Longjie), just before the vicariate's See was moved to Yun-nan-sen (Kunming) in 1881. With a good grasp of Mandarin, he was sent to assist his elder colleague Jean Terrasse who was missionizing among the Han in the Yang-pi district (Yangbi) southwest of Tali Lake. It is in the early years of this assignment, for which he nurtured no particular affection, that British envoy Archibald Colquhoun met him when venturing in 1882 into southwest China from his base in Burma. Colquhoun asked for Vial's assistance to return to Bhamo. Vial thus accompanied Colquhoun and his party to upper Burma. To do so he was absent from his mission for about six months and got severely reprimanded by his Bishop for this unauthorized leave. On the brighter side, this expedition, recorded and made public by Colquhoun as well as by Morrison, has contributed to Vial's notoriety among the English-speaking readership among whom he became better known than most of his MEP colleagues in the region. ${ }^{11}$ Incidentally, this trip to Burma may also have saved Vial's life. During his absence, his colleague Terrasse was murdered along with several of his converts in 1883 during anti-French unrest stirred by Chinese mandarins in reaction to the unleashing of French military operations in Tonkin.

In 1885, Vial was sent to the post of Te-tse-tsen $50 \mathrm{~km}$ east of Kunming, again among the Han. It is there, through his travels to the more remote areas of this new mission, that his interest for the Lolo

\footnotetext{
${ }^{11}$ Colquhoun, Archibald R. Across Chrysê. A Journey of Exploration through the South China Border Lands from Canton to Mandalay. London: Sampson Low, Marston, Searle and Rivington, 2 volumes, 1883; Morrison, George E. An Australian in China. London: Horace Cox, 1895.
} 
(as he preferred to write their name) first appeared. By 1887, to be able to live closer to them he rented a house at a nearby Lolo market town of Tien-sen-kouan. In 1888, he moved permanently further south in the high valley of the Lou-lan river (today Lunan), three days east of Kunming, and settled in a Lolo village named Lou-mei-y (Lumeiyi) inhabited by the Gni-p'a subgroup (also called Sagni by Vial, today known as the Sani). This is where he would spend the remaining 30 years of his life. Vial gradually endeared himself to these "fearful and timid" people who had endured Han hegemony for centuries, and had been vanquished without ever being entirely tamed. Highly critical of the Han and their cultural expansionism, Vial quickly made it his duty to help his new converts in their struggle against cultural oblivion. He set out on this mission by bringing Gni-p'a history and culture out of the darkness where the Han's "contempt and ignorance" had kept them. In his own words, published in the comptes-rendus of 1888, he decided to become "the historian of this humble nation." In short, as Margaret Byrne Swain summarised in 1995 in a solid essay devoted to Vial's ethnography of the Gni-p'a, "Vial's view of Sani culture was remarkably positive, and he was sensitive to their subjugation and the encroachment of Han society." 12

Vial's commitment to the Gni-p'a cause was based on a blend of rational and emotional motives, with clear and unrepentant expressions of favourable bias towards "his children:"

I love [the Gni-p'a Lolo] because he is good; I love him because he is scorned. I would like to have him known [for] pushing aside the plethora of prejudices that fill books and that are unabashedly accepted as proven facts. ${ }^{13}$

A dramatic and near fatal encounter with burglars in his church in 1892 forced him to interrupt his project and seek immediate medical attention in Hong Kong and France. Vial returned to Lou-mei-y in 1894 and two years later, in 1896, he was starting his most notorious and, in some aspects, disputable project. In the nearby site of Tsin-

${ }^{12}$ Swain, Margaret Byrne. "Père Vial and the Gni-p'a. Orientalist Scholarship and the Christian Project." In Cultural Encounters on China's Ethnic Frontiers, ed. Harrell, Stevan, Seattle and London: University of Washington Press, pp. 140-85, 1995, p. 178.

${ }^{13}$ Vial, Paul. Les Lolos. Histoire, religion, mœurs, langue, écriture. Etudes Sino-Orientales, part A. Shanghai: Imprimerie de la mission catholique, 1898, i. This translation by Swain 1995, p. 161. 
chan-keou, Vial bought land from a Chinese landlord and started erecting a village he wanted to make a model of hygiene and agricultural efficiency for the natives. He decided himself who would inhabit this new site. His first guests were Miao families who migrated from a distance. After six months of this regime however, the guests decided to quit the site and Vial eventually replaced them with Gni-p'a families, with moderate success. His explicit aim in this strange enterprise was to "free" these natives from the exploitative, feudal hegemony of Han landlords, and educate them; the more mundane dimension of the venture was to generate rent in kind and money for the mission. Vial was thus replacing the ancient landlords with himself as a new, presumably more benevolent one, not an uncommon practice across the MEP missions in Asia. ${ }^{14}$

To understand how such a venture was even financially feasible for a lone cleric in the remote Chinese highlands, we need to briefly introduce here a character who had a key influence on Vial's life and work. Vial is a rare case of a simple missionary for whom important fragments of his personal correspondence can be found in the MEP archives in Paris. Throughout his 32 years in Yunnan, our priest had written almost weekly to a personal benefactor and patron, Viscountess Marie de la Selle residing at Château de la Tremblaye in the Loire region, whom he called in his letters "my beloved sister." The letters she received from Yunnan were later donated to the MEP archives (but she unfortunately appears not to have kept copies of the ones she sent him). Vial had been introduced to Viscountess de la Selle during his years with the Jesuits and their correspondence flourished from there. From Yunnan, Vial wrote to her about his daily life, the vicissitudes of his ministry, his hopes and successes in converting the natives, or any initiative he was thinking of. A wealthy spinster and devout friend, Mademoiselle de la Selle unfailingly supported Vial's endeavours with regular financial donations, which he was authorised to keep for himself and his mission as was the rule in his Society. Each vicariate had, in principle, to be self-sufficient financially; hence the need to solicit private donors and generate income at all levels in the missionary ranks. To the occasional shipments of books, clothes, good wine and even crystal ware

${ }^{14}$ Vial described the initial steps of this venture in articles published in Annales de la Société des Missions-Étrangères (vol. 61:15-38) that were later reprinted in the 62-page booklet Miao-Tse et autres. Vannes: Imprimerie Lafolye Frères, 1908. 
that arrived to Vial from France via Tonkin were regularly added lump sums destined to support his annual expenditures and projects. ${ }^{15}$

It is with this wealth that Vial had his model village erected in Tsinchan-keou: he called it St-Paul-la-Tremblaye, blending the name of his patroness' abode with his own patron saint. Along with streets, houses and a school, Vial had what he called a "château" built for himself, although it was really little more than a simple but solid dwelling. He distributed tools and cooking implements to his farmers and kept the settlement operational. He spent the rest of his life between his Loumei-y post and St-Paul-la-Tremblaye. Occasional details on the progress of this operation are given in his popular publications throughout the following years; what happened to it after his death is unknown.

Vial seems to have been in regular contact, in person or through his correspondence, with a good number of his MEP colleagues in the region. Vial's initial impression of his younger colleague Liétard was not very positive. Based in adjoining missions for the five years that the latter would stay in Lan-ngy-tsin (1898-1904), Vial and Liétard had managed to squabble by early 1900 . They made their reconciliation a few months later, but this did not stop Vial from writing to his patroness that Liétard was "a vain character spoiled by a too comfortable youth." Nevertheless, over the next five years, Vial was in regular contact with Liétard, as well as Kircher who he particularly liked and to whom he gave a camera similar to his own - both paid for by the Viscountess. This tool allowed Vial to adorn his articles in popular missionary journals with many pictures (his, and often Kircher's as well) depicting places, objects, and people, a definite bonus from the point of view of the publishers.

During 1900-1901, Vial and Kircher — but not Liétard — took refuge in nearby Tonkin to weather the Boxer Rebellion. ${ }^{16}$ It is confirmed that

${ }^{15}$ Here is an opportunity to mention that once in their postings, MEP missionaries were free to buy, borrow or copy any book of their choosing for their personal use; the ecclesiastical authorities did not consider it their role to attempt to police or overlook this activity. Missionaries with specific interests and matching financial means, like Vial here, could thus assemble a substantial personal library. Unfortunately, MEP archives have not kept trace of these personal possessions, which were claimed back by families or dismantled and redistributed within the congregation at the death of their owner. It is sad that at least a list was not made, which would have greatly helped us to appreciate the intellectual curiosity of our author in the field.

${ }_{16}$ Contrary to this information gathered from his own letters, Vial's official biographical note published by MEP states instead that he stayed in Yunnan during the rebellion. Edouard Maire stated that 22 missionaries from Yunnan fled the vicariate 
during that trip, Vial met Léon Girod in Lao-kay (Lao Cai) as well as a number of the missionaries active in Upper Tonkin, and had a chance to compare notes. It is also probable that this is when Kircher met with young François Marie Savina who had just arrived in Hưng-hoá. Back in Yunnan within a year, Vial returned to Lou-mei-y. From 1905 he started teaching French to the Gny-p'a youth in a language school he had opened. He designed and published French grammars for Gny-p'a language and wrote a textbook on arithmetics. He also translated a Catechism, produced language dictionaries, and translated Lolo tales.

Devoted exclusively to life among his converts, Vial died of illness in Lou-mei-y in 1917 at age 62. According to his will, he was buried in the Lolo village of Ve-tse, a few kilometres from Tsin-chan-keou / St-Paul-la-Tremblaye.

Vial's publishing life spanned from 1888 to his death in 1917. By far, his most regular publications were directed at the popular outlets, Annales de la Société des Missions-Étrangères and Les Missions Catholiques, with several of these articles later collected to be published as booklets. Put together in this way, these otherwise disparate articles gained a new coherence, doing more justice to their author's scholarship. These articles are fine examples of generalist texts based on a long acquaintance with a specific highland society, conducted without formal training and, thus, dwelling on personal experience and character to produce entertaining narratives that readers in France loved to follow. Despite the absence of important elements such as dates, locations, general circumstances, and an overall critical sense that has been kept to a minimum in order not to obstruct the flow of the prose, these pieces still have some ethnographical value and can play a supporting role in a serious analysis, as demonstrated by Swain. ${ }^{17}$

Vial's three most significant learned contributions were published independently from missionary journals. These are De la langue et de l'écriture indigènes au Yû́-nân [On indigenous language and script of Yunnan], a 1890 treaty on native languages and scripts; Les Lolos. Histoire, religion, mœurs, langue, écriture [The Lolo. History, religion, mores, language,

for 10 months in 1901, 19 of whom to Hong Kong and Shanghai, the three remaining ones being unaccounted for - and could well be the ones who retreated to Tonkin. Maire, Edouard. "Mission du Yunnan. Traditions et souvenirs. Bulletin de la Société des Missions-Étrangères de Paris, vol. 1. Pp. 10-16, 48-55, 70-76, 134-142, 206-215, 346-355, 403-410, 524-533, 592-603, 651-661.

17 Swain, "Père Vial and the Gni-p'a," $152-158$ in a section called Popular Writing; and 2001. 
and script], an ethnographic study of the Lolo published in 1898; and Dictionnaire Français-Lolo, dialecte Gni [French-Lolo dictionary, Gni dialect], his impressive 1909 French-Lolo dictionary. ${ }^{18}$ This latter work is undoubtedly his most voluminous publication and, combined with his 1890 treaty, showed that language and linguistics was the prime focus of his scholarship, one that still receives much attention today. ${ }^{19}$ There is a wealth of ethnographic information grafted onto his lexicons, especially in the detailed selection of examples.

However, it is within his 1898 Les Lolos, "an effort of conscience and love" ${ }^{20}$ that his better ethnographic work has been embedded, which best reveals his intentions, mindset, and methods. Although Les Lolos is only 71 pages long, it offers a considerable amount of information. Showing similarities with Liétard's Au Yun-nan, which would only be published 15 years later and for which Les Lolos' structure might have served as a model, the fields forming the book's divisions (nine chapters and one appendix) give the scope of the study: from history, religious tradition (including mythology), language and writing, literature and poetry, to mores, customs, birth, marriage, death, and cosmography.

Chapter Seven comes as an interesting offering. It is a summary of the correspondence Vial received from fellow missionary Vincent Roux (1840-1917) who worked during the same period in nearby Guizhou. Vial seeks his colleague's views on the Dong and Miao converts' cultures in relation to specific themes he found to be of importance in Gni-p'a culture. Only partially treated, these dialogues do not really yield their full potential, but they clearly constitute an indication of Vial's methodological strategy in studying Gni-p'a distinctiveness by putting it in a broader cultural context. Thus, in his mind, such a comparison was an effective tool with which to conduct his analysis. The same method surfaces again in the appendix, incorporating a conversation Vial had with another colleague we heard of earlier, Jean-Marie Martin, on the origin of the ethnonyms 'Lolo' and 'Gni'.

It would be redundant here to present Les Lolos chapter by chapter since this task has already been performed more than competently by

18 Vial, Paul. De la langue et de l'écriture indigènes au Tû-nân. Paris: Ernest Leroux, 1890; Vial, Les Lolos; Vial, Paul. Dictionnaire Français-Lolo, dialecte Gni. Hong Kong: Imprimerie de la Société des Missions Étrangères. 1909.

19 American linguist of Southeast Asia James Matisoff, for instance, uses Vial's texts in his study of Sino-Tibetan languages.

${ }^{20}$ Opening words of Vial, Les Lolos, I. 
Margaret Byrne Swain, to whose work I redirect the interested reader. ${ }^{21}$ At this point, I will limit my commentary to general remarks of use to this book.

In terms of method, Vial believed in understanding local customs and using vernacular languages to proselytize ably among the natives. He advocated by the same token that the missionary has to locate himself within the mindset of his prospective converts, rather than expect them to reach him unassisted, be it physically or culturally. His interest in language nevertheless exceeded this strategic pragmatism. Instead, it followed the widespread agreement at the time that the most scientific means by which groups could be distinguished and ethnicity ascertained was by undertaking linguistic classifications. As we saw, he also believed in the importance of cross-checking his own data with other first-hand observations by Europeans that he could obtain, advocating, as many Western observers had, that Han documents written on non-Han groups were biased and misleading. Deeply distrustful of the Han Chinese, he preferred to go the necessary distance to gather first-hand material. He declared "Sinologists are legion to travel through the labyrinth of Chinese literature. I prefer to travel on foot, and collect the information myself." ${ }^{\prime 2}$

While Vial was in tune with many of the precepts and conceptions of the Orientalist movement thriving in France and the West at the time, he also understood that if one was to undertake good ethnography it needed to be performed in the field, with the people, and over a significant period of time. As Swain observed, "Vial worked side by side with the literate specialists who transcribed texts, and he recorded oral tradition himself in the 'usual' field method." Assessing Vial's contribution to the ethnography of the Gny-p'a (Sani) globally, she also states:

The subtext of Vial's missionary letters and scholarly writing about the Sani was Orientalism, mediated by his commitment to conversion and expressed in his dialectical role as missionary-ethnographer. [...] Vial believed in both cultural difference and cultural transformation. ${ }^{23}$

In a subsequent article stressing the relevance of that 'incidental' ethnographer for today's reality, Swain remarks:

${ }^{21}$ Swain, "Père Vial and the Gni-p'a," 158-175, the section is called Scholarly Writing and it addresses the three main texts mentioned here.

${ }^{22}$ Vial, Paul. "Deux mois chez les Miao-tse." Les Missions Catholiques, p. 474, 1908.

${ }^{23}$ Swain, "Père Vial and the Gni-p'a," 180, 183-4. 
In the 1990s, one hundred years after he built his mission in Lunan County, Vial is no longer vilified by revolutionary rhetoric, but instead influences various groups within Lunan. For Sani intellectuals he provides tantalizing clues to what the language and culture was like, as well as their long-term legitimacy as a distinct group. For the State Tourism Bureau, Vial's history of European activity and his photographs are very useful in marketing Lunan as a unique international destination. For local Catholics, who are no longer 'underground' but are building churches in several communities, Vial is revered and remembered for bringing a new heritage to Lunan. ${ }^{24}$

It should not come as a surprise that Vial, in his published work on the Lolo, did not quote his colleague Alfred Liétard, also a scholar of the Lolo. Vial's active life as an author of ethnography on that group had pretty much ended when, in 1909, Liétard published his first scholarly text. Vial however, in his Dictionnaire Français-Lolo, dialecte Gni, published in 1909, could certainly have made use of Liétard's linguistic competence developed over the prior ten years. ${ }^{25}$ Vial could even have used some of Liétard's pieces in popular missionary journals to beef up his own publication. But there is no mention of him in Vial's work. On his side, Liétard had already written in 1904 that Vial's 1890 study on the Lolo was "authoritative." "26 However, later, in Au Yun-nan published in 1913, Liétard made just about no use of his elder's publications and stated that he had been asked to publish this work because the Lolo of Yunnan and their languages were insufficiently well known. It is difficult not to sense here a veiled critique of Vial's earlier work. I could not find evidence of the two men disagreeing openly after their squabble in spring 1900, but the near total absence of collaboration and cross-referencing between them stands oddly. As Swain surmises, "what might have been a fruitful working relationship between the two missionaries is not reflected in their later publications." 27

Reading the work of both priests, it is also difficult to avoid concluding that Vial, with all his goodwill and dedication to studying the Lolo,

\footnotetext{
${ }^{24}$ Swain, Margaret Byrne. "Native place and Ethnic relations in Lunan Yi Autonomous County, Yunnan." in Stevan Harrell (ed.) Perspectives on the Yi of Southwest China. Berkeley: U. of California Press. Pp. 170-194, 2001. P. 189.

${ }^{25}$ Vial, Paul. Dictionnaire Français-Lolo, dialecte Gni. Hong Kong: Imprimerie de la Société des Missions Étrangères. 1909.

${ }^{26}$ Liétard, Alfred. "Le district des Lolos A-chi.", part 1. Les Missions Catholiques 1811: 93-96, 1904. P. 94.

27 Swain, "Père Vial and the Gni-p'a," 160.
} 
underpinned by his 30 year presence in the field and his linguistic competence, has chiefly produced general pieces informed by a considerable amount of first-hand observation but comparatively little scholarship. We know for sure that supplies of books were not a problem for him, so we can only conclude that either he did not think about obtaining them, did not want to, or simply omitted to mention using them if he had. As a consequence, Les Lolos mentions in passing a precious few published authors but does not engage with their ideas or propositions. One is tempted to suspect that Vial might have even not read them. Liétard, by contrast, skilfully engaged with many authors, discussed their propositions, refuted their arguments, and logically established his own ones. A key difference between them could stem from the fact that Liétard had lived among several different Lolo groups, harvesting data on a much larger geographical and cultural scale than his elder. His ethnology does bear the quality mark of his wider vision.

There can be no doubt that both men were competent and skilled ethnographers and produced important ethnographic texts for future generations. Both received academic distinctions - for Vial, it was the Stanislas Julien prize awarded to him in 1911 by the Académie des Inscriptions et Belles-Lettres. But in my opinion, only Liétard managed to reinvent himself as an ethnologist.

\section{François Marie Savina and 'His’ Miao}

I have wandered over parts of Asia, I visited the Annamites, the Muong, the Kha, the Thai, the Man, all tribes of the Miao, and I have met in all those places men who were not any more savage than me! (Savina 1924a: 271)

After this detour beyond the borders of Upper Tonkin, examining the life and production of François Marie Savina allows us to focus again on this particular vicariate. Moreover, now equipped with the details highlighted earlier in this book regarding the history, layout, and political situation of Upper Tonkin, we can better exploit the missionary archives and published data on the life and whereabouts of this highly original man.

I would argue that François Marie Savina was not just another MEP missionary active in the Southeast Asian massif in the early years of the 20th century. In terms of formation, circumstances, and interests, it is true, Savina was in a situation comparable to his Yunnan colleagues such as the ones we just met. However, he performed 
an inventive form of ethnographic exploration on a vast territory and established his reputation pretty much independently from any of his other colleagues.

\section{A life of Savina}

In terms of biographical information, despite a variety of clues, less is available about the life of François Marie Savina (1876-1941) than one would hope. This relative paucity is somewhat odd considering the impressive number of publications that were left by this solitary worker over the 40 years he spent in Asia, and his comparatively late death at the age of 65. Also, given the fact that large segments of his life were spent in the company of colonial diplomats and military officers who generated records routinely, this near silence is intriguing. Surely some of these witnesses must have produced accounts that could help shed light on Savina's life and whereabouts in Asia. Yet, it appears that barely any published biographical details have survived to this day beside two official MEP accounts - an obituary and a short biographical note - and another obituary in the popular journal Missionnaire d'Asie. To these, one can add a handful of reviews of his books and the modest amount of biographical detail Savina himself agreed to share with his readers in his published works.

From that basis, one gains a picture of Savina as a man who was anything but the embodiment of a regular colonial MEP missionary. Unlike most of his MEP colleagues who remained permanently in their vicariate - think of Vial, who spent the last 30 years his life in the same posting - Savina was only attached to a particular mission in the field for three or four relatively short periods. With each of these stays ending with his departure for one form or another of commissioned work beyond the borders of the Upper Tonkin vicariate, he appears to have been targeted as a candidate for specialized assignments involving various non-missionary tasks.

The most evident hypothesis to explain Savina's remarkable mobility suggests that we should look in the direction of his particular talent for languages. A talent in demand in the missions of course, but one also valued in colonial diplomatic, intelligence, and military circles. This alone could have justified his transfer from one linguistic region to another to learn and record vernacular idioms or act as an interpreter in periods of crises. However, language proficiency alone is hardly a sufficient explanation for a missionary's roving, and we can rest assured that for Savina's superior, Bishop Ramond, doing without 
a gifted polyglot for years on end in a multiethnic vicariate badly in need of all able bodies, required a major justification. For at least two substantial periods of time, from 1918 to 1921 and from 1925 to 1929, Savina was actually on official leave from his congregation in order to collaborate with other branches of the colonial authorities. The first time was with the military in Laos, the second with a diplomatic mission to the island of Hainan in China. Then, Savina was released for several years from his duties in the field to work in Hong Kong on his publication projects, culminating with a five-year stay from 1934 to 1939 when working on the completion of his multilingual dictionary. ${ }^{28}$ Each time Savina returned to the Upper Tonkin vicariate, to which he remained officially attached all his working life, instead of then being sent back to his previous post he was consistently given a new field assignment. Closer scrutiny is thus needed to make sense of the context in which this man managed, despite all this motion, to write and publish a massive amount of informed ethnography and comparative linguistics on not one, but several highland groups in the Mainland Southeast Asian massif.

François Marie Savina was born on March 20, 1876, in Mahalonen-Cornouaille, a rural hamlet with a population of a few hundred, in the department of Finistère, Brittany, France. His parents, we have to presume, were rural folks, most likely peasants. There is no information as to how many brothers and sisters Savina may have had. Competent in Breton, he also learned the basics of other Celtic dialects judging from his reference to them in his publications. It is in his native Mahalon that he attended primary school before moving to nearby Pont-Croix to study at the minor seminary, then to the major seminary in the regional head town of Quimper, from which he graduated in 1897. Thus, to this point, his education was done purely in very provincial institutions. Young François then decided to permanently adopt religious life and devote his existence to missionizing overseas. In September 1897 at the age of twenty-one, he joined the MEP seminary in Paris where he stayed for four years, studying and preparing for priesthood. Ordained in June 1901 at the relatively late age of 25, Savina then learned that he was assigned to the new Upper Tonkin vicariate, and left for Hanoi the next month, on 24 July.

\footnotetext{
${ }^{28}$ Savina, François Marie. Guide linguistique de l'Indochine française. 2 vol. Hong Kong: Impr. de la Société des Missions Étrangères. XVIII.2516 p. 1939.
} 
Upon his arrival in Indochina, he underwent the mandatory stay in Hanoi to acclimatise, meet the authorities, and start learning the basics of the Vietnamese language. After this induction period, in all probability in 1902, he was dispatched to the Upper Tonkin vicariate headquarters in Hưng Hoá to join his designated mission and perfect his knowledge of Vietnamese, while also beginning to study Chinese.

The first substantial hole in Savina's biography appears from 1902 to October 1906. From the documents available, what he actually did during these years is not clear at all. Normally, after spending about a year in the vicariate's See to learn the ropes, new recruits were then quickly sent to their first posting. There are no traces anywhere of such a first assignment for Savina, and instead it looks as if he was somehow held back in Hưng Hoá. One must then presume that he stayed there either to perfect his language skills, learn more about his profession, cure an illness, or other motives that were better left 'off the record'. Just as plausibly, he might have been asked to perform some administrative task for the See, often the case for recruits gifted as accountants or educators, or with less aptitude for field work. Whatever the case, such a long period at the headquarters of the vicariate without being assigned to a specific mission, while not appearing in any record, was unusual.

At last, Savina's name pops up for the first time in the vicariate's comptes-rendus in the year 1907 in relation to his first assignment. This supports the thesis that before this, he had not been posted to a particular mission. In these 1907 comptes-rendus, Savina is introduced to the readership as a newcomer to the Ha-giang mission. Surprisingly for a fresh missionary, he appears to have been given licence to select a location where he could create his own post. He was quoted saying that:

On 1st October last [1906], I received my new destination to the Tay country in the high region. After wandering the territory between Tuyenquang and Ha-giang, I decided to settle down in Vinh-tuy, where the Con and Clear Rivers meet. On 19 March [1907], my modest church dedicated to Sainte-Anne was finished and I could celebrate mass in front of over 100 pagans coming from all around the neighbourhood. The Tay who I must evangelize are mostly White Tay. ${ }^{29}$

Whether Savina, when he settled in Vinh-tuy, already spoke one or the other of the several forms of Tay (Tai) languages found in Tonkin

29 Savina, Comptes-rendus 1907: 183. 
is unclear. Could he have devoted time to learning the Tay dialect in his 1901-1906 formative years? Against this hypothesis but without providing evidence, MEP colleague Léon Trivière declared that Savina learnt Tay in Vinh-tuy, and later in Pai-xat, and Lai-chau. ${ }^{30}$

Thereafter, Savina's name appears in the annual reports until 1911 inclusively, along with his colleagues D'Abrigeon and Blache working in that same region. During those five years of visibility, Savina resided continuously in his Vinh-tuy mission and was described as evangelising among the Tay and the Man (Yao). He is reported to have also paid substantial visits to the settlements of Pai-xat and, more surprisingly, to the White Thai stronghold of Lai-chau farther west, at the heart of the Sip Song Chau Tai. One hypothesis that might explain this venturing into the Lai Chau region is that he could have been needed there to act as an interpreter for the authorities in the highly political succession entanglement following old Deo-van-tri's death in 1909. ${ }^{31}$

In his Vinh-tuy mission, Savina appears to have been well accepted among the montagnards, but conversions were few and far between. This lack of success might have left him with time on his hands, opening the door to his pursuit of other interests. Indeed, it is in Vinh-tuy in 1910 that the first trace of his commitment to languages and linguistics appeared, when the comptes-rendus mentioned that he was working on his Dictionnaire Tay-Annamite-Français, a bulky piece he published in Hanoi the following year. The production of such a useful tool for evangelising was valued by the authorities - religious, administrative, as much as military - and must have received their full support notwithstanding the Reverend's lack of success in converting the natives. ${ }^{32}$

After 1911, a second period of unclear movement began during which Savina's name as well as that of the Vinh-tuy post inexplicably disappeared from the comptes-rendus, not to figure again before 1919 when a brief mention was made of his departure to Laos the preceding

\footnotetext{
${ }^{30}$ Trivière, Léon. "Révérend père F.-M. Savina." Missionnaire d'Asie, pp. 25-29, 1953, 26.

${ }^{31}$ In the years preceding the death of the White Thai leader, objections to the hereditary transmission of power to his sons were raised by the colonial authorities. Auguste Pavie had included this hereditary right in the 1889 treaty but ageing Deo and his sons had to argue strongly before the clause was finally accepted and implemented. See the correspondance at CAOM, RST-56476, 1903-1911, 'Succession politique de Deo Van Tri. Constitution de la province de Lai Chau'.

32 Savina, Dictionnaire Tay-Annamite-Français. But could it not also be precisely because Savina was busy with his dictionary that his conversion record was not exceedingly good?...
} 
year. The likelihood that he was simply forgotten by the author(s) of the comptes-rendus must be ruled out as every active missionary's name was scrupulously mentioned, along with details about their work and the progress of the missions. Such vanishing from official missionary reports is intriguing and invites speculation. Where was Savina during the years 1912-1918? Perhaps he was ill and repatriated to the vicariate headquarters, which was not a rare occurrence. ${ }^{33}$ However, falling ill in the line of duty was part of the expected hazards of missionizing, and such an occurrence was usually treated as an opportunity to emphasise an individual's commitment to the cause. As such it would have deserved at least a mention in the reports. Another possible explanation is that Savina carried out his work in Vinh-tuy, but failed to appear in the missionary news because he did not write any annual report to his Bishop, a right the MEP did grant its members, although very few actually took it up. ${ }^{34}$ Another possibility is that for some reason, Savina may have been removed from his mission in controversy, which would also have justified a studious silence.

Perhaps, the most appealing explanation for this silence is that Savina may have been busy with activities about which the Directors in Paris were either not told, or if they were, did not wish to see included in public reports. Such activities did not necessarily have to be reprehensible, for instance they could have been connected to military intelligence, or have been an assignment that the general public, funding the MEP, might not have readily accepted as a legitimate task for a missionary in the field. In line with this hypothesis, it is thinkable that Savina was requested to join the military as an interpreter to support the quenching of a long 'rebellion' by the Miao in the Third Military Territory, in Ha-giang region. ${ }^{35}$ Certainly, the subject of his next publication indirectly supports this hypothesis.

${ }^{33}$ On this subject, Trivière actually mentions, without dating each of these events nor giving any detail, that over his life in Asia, Savina had suffered typhoid fever, malaria, dysentry, "a tragic event at sea in 1926 that nearly cost him his life", a fall from a horse in 1930 earning him a long stay in a hospital, and several encounters with thieves. Trivière, Léon. "Révérend père F.-M. Savina." 28.

${ }^{34}$ From conversation with Father Gérard Moussay, Chief Archivist, MEP. April 2001.

${ }^{35}$ See on this event, among many other documents, CAOM RST56485, 1912 to 1914 "Soulèvement des Meo. Arrestation à Dòng Van et relégation à l’ìle de la Table puis à Quang-Yèn de Chiong Mi Tchang dit Hùng-Mè-Giang, prétendant roi des Meo." 
What we do know on the period 1912-18 is that some of it was devoted by Savina to completing the studying, readings and writing needed to launch a major publication in 1916. That year, he published his Dictionnaire miao-tseu-français in the scholarly Bulletin de l'École française d'Extrême-Orient. ${ }^{36}$ It has been confirmed that by 1911 Savina had already learnt Vietnamese, studied Chinese, and he knew enough Tay to produce a sizeable dictionary. Between 1911 and 1916, in order to compose a new dictionary on a new and totally unrelated language ${ }^{37}$ he certainly had to have lived in close enough contact with Hmong/Miao highlanders to properly learn their language, devise a writing system, and put together a manuscript of 200 pages. Trivière surmised that Savina learned the Miao language in the garrison town of Lao-kay and in Hmong villages around Chapa, thus substantiating the hypothesis that the Father had stayed there for significant periods of time before 1916. ${ }^{38}$ Combined with his normal missionary work in Vinh-tuy, these extra field stays and extensive writings would have been a Herculean task. It is thus to be assumed that Savina was discharged from at least part of his proselyte duties for a few years to learn the Hmong/Miao language in situ and produce a dictionary. Just who would have given him such a commission however, and exactly why, remains open to speculation.

Also, the 1910s were troubled times. In France, the impact of the Third Republic, which had famously revoked the privileges allowing priests to dodge military draft, was still strongly felt. 'Curés, sac au dos.' Priests, pick up your rucksack! was the popular dictum. War was imminent in Western Europe, subsequently breaking out in 1914 for four years. In the meantime in Indochina, in addition to the local effects of the war in Europe, severe unrest had once again spread to the Tonkin mountains due to a number of Imperial army groups fleeing victorious

${ }^{36}$ Savina, François Marie. "Dictionnaire miao-tseu-français, précédé d'un précis de grammaire miao-tseu et suivi d'un vocabulaire français-mioa-tseu." BEFEO, vol. XVI, no. 2, pp. 1-189, 1916.

${ }_{37}$ Miao languages, including the form Savina learnt, the Hmong language, are part of the unique miao-yao language family, a distinct cluster within the austro-asiatic family.

38 Trivière, "Révérend père F.-M. Savina," 26. Several colonial authors have noted the reluctance of the Hmong to visit Lao-kay town, let alone to live there. To learn their language, Savina would have had to live among them. He could have lived in a number of locations in the Fourth Military Territory, and the recently established military health station in Chapa was certainly one of the likely locations. 
Chinese Republican troops after 1911. As had so often been the case before, such 'rebels' roamed and pillaged Yunnan, Guangxi, northern Tonkin and northern Laos, and the French military command set up additional partisans in the Tonkinese mountains to help contain this new outbreak of Chinese piraterie. From the comptes-rendus, we learn that Savina had to pull out of Vinh-tuy at least once due to such threats and the colonial military responses to them, it being noted that "[sometime in the 1910s] following difficult circumstances, Mgr Ramond had to remove the two missionaries in Ha-giang and Vinh-tuy on the Clear river." 39

Whatever these difficult circumstances were, with his local knowledge and his proven language skills, it is doubtful that Savina would not have caught the attention of, and been drafted early on by, the colonial military command to assist in the task of organising partisan resistance to the Chinese intruders. Evidence of this military connection became apparent when Savina was sent to Laos from 1918 to 1921 to assist in the crushing of a particularly energetic 'Meo rebellion' that had spread from western Tonkin. ${ }^{40}$ It would not be an exaggeration to suggest that before being sent for three years on such a sensitive task in a neighbouring protectorate, the colonial machine must have already had the opportunity to appreciate Savina's competence, precisely during those 1912-1918 years. ${ }^{41}$

Other indications exist as to Savina's whereabouts during those years. Father Léon Trivière assessed in his biographical note on Savina that between 1903 and 1925, Savina spent time with various tribes to study their languages, first in Vinh-tuy, Pai-xat and Lai-chau for the Tay language, in Lao-kay and Chapa for Hmong (Miao), but also in Dongdang and Cao-bang for the Nung language and in Monkay and Tien-yen for the Man. ${ }^{42}$ It is also established that between 1906 and 1911 and again

${ }^{39}$ Comptes-rendus 1919: 160.

40 See for instance CAOM GGI26432, 1919, "Conseil de défense de l'Indochine. Opérations militaires contre les Méos du Haut-Laos," and CAOM GGI28375, 1920-1921, "Agitation chez les peuplades Méos (Sorciers Batchai). Régions Lai-chau, Dien-Bien-Phu, Son-la."

41 Another celebrated colonial ethnographer of upper Tonkin, Auguste Bonifacy, was commander of the Third Military territory and based in Ha-giang from 1911 to 1914. It thus becomes appealing to reflect on the possibility that Savina and Bonifacy might have met, compared notes, and indeed influenced each other in their scientific endeavours. There is unfortunately no evidence of this in official documents.

42 Trivière, "Révérend père F.-M. Savina," 26. Savina himself stated in 1924 (Savina, 
between 1918 and 1921 Savina was kept busy in Vinh-tuy and Laos respectively, leaving only the (unlikely) years 1903-1905, and the (more likely) period 1912-1918 to conduct significant field visits and learn new vernacular languages or, at least, reside in a region where native speakers could visit him regularly. Indeed, Savina himself stated that he was in Lao-kay town in September 1914 in the company of a few 'Meo' (Hmong). He also mentions having been in contact in 1915-1917 with the Miao in the provinces of Lao-kay, Yen-bay, Son-la and the Lai-chau Military Territory, all in Upper Tonkin. The introduction to his Dictionnaire miao-tseu-français, bearing the date September 1915, was signed in Tu-lê in the Third Military Territory. ${ }^{43}$

It is relevant to note that the towns of Lang-son, Cao-bang, and Monkay were situated well outside the borders of the Upper Tonkin vicariate, lying within the Dominican's domain east of the Clear River. A short comment in Savina's obituary in the 1949 comptes-rendus actually states that our missionary "shared his science with the Dominican Fathers in the Langson prefecture at the time of its foundation," the Lang-son prefecture, established in 1913, having recently received reinforcements from the Dominicans of the Province de Lyon, France, to assist those from the Manila province. ${ }^{44}$ Indeed, in February 1918, Savina acknowledged leaving the 'Miao country' in Upper Tonkin to reach the Kouangsi (Guangxi) border. That area was not under MEP ecclesiastic control, but it was, nevertheless, under French colonial military administration with Monkay, Lang-son and Cao-bang the main urban settlements in the northeastern Military Territories.

A special kind of dispensation would have had to be given to allow a missionary in charge of a mission in a MEP vicariate to leave his post and cross missionary society borders for the mere sake of studying 'tribal' languages. Again, perhaps that missionary had a commission from the colonial administration, perhaps even the military. The entire

\footnotetext{
François Marie. Histoire des Miao. Hong Kong: Imprimerie de la Société des MissionsÉtrangères, XXII-304 p. Republished in 1972 [1924a], xvi) that he had spoken Man language with Man in Tonkin, Laos and Kouangsi (just over the border from Caobang). He then compared what he had learnt with additional vocabulary in Yunnan, Se-tchouan, Koui-tcheou and Kouangtong obtained from secondary sources, thus indicating that he himself had not been in these Chinese locations.

${ }^{43}$ Savina, Histoire des Miao, 237; Dictionnaire miao-tseu-français.

${ }^{44}$ French Dominicans had arrived in 1902 to help the Spanish Dominicans in northeastern Tonkin, Spain having recently been ousted from the Philippines, the long time Dominican base in Southeast Asia.
} 
north Tonkinese periphery bordering China had been under military administration since 1891, a control that superseded all other forms of territorial allocation such as the vicariates.

We have now reached the year 1918 in which Savina moves on temporarily to Laos. In a four-page report on his activities in Laos in relation to the northern Indochina 1918-1921 Meo revolt reprinted in his 1924 Histoire des Miao, Savina points out that his involvement in that affair started when he was sent to Chapa in August 1918 to question a group of Miao/Hmong peasants who had concerned the authorities by gathering in a nearby village.$^{45}$ When the rebellion broke out later that year and spread from Tonkin to Laos, Savina was sent by the Government of Indochina to the less well controlled Xieng Khouang region in Laos (called Tran-ninh in Vietnamese), with a special commission to stand by the military and support operations aimed at crushing the 'Meo' rebellion. He was to stay there for the duration of the uprising until its leader's death in 1921. Two photographs published in Histoire des Miao tell parts of that story, showing Savina in April 1920 with a small military party during the inspection of a Meo village, and again that same year standing in front of the veranda of a colonial building flanked by his Nung assistant and a Meo chief. When the revolt came to an end, Savina produced a classified Rapport sur la révolte des Méo du Nord Laos for the authorities, an enticing but elusive text of which only the reference seems to remain. A sanitized version of that report was eventually published in 1924 under the title Considérations sur la Révolte des Miao. ${ }^{46}$

${ }^{45}$ Savina, Histoire des Miao, 236-9. This was the Ba Chay (Pa chay) uprising, also known as the Mad Man's Rebellion (Révolte du Fou in French colonial archives). This important armed Hmong uprising against the French colonial power started in Lao Cai province in northern Vietnam in July 1918, in reaction to what was perceived locally as injustice and abuse. The Hmong resented the high level of taxation extorted by the White Thai of Lai Chau who had been authorized to carry on this ancient practice by a complacent French administration. The initial unrest quickly spread among the Hmong in northwest Tonkin and penetrated into northern Laos, where most of the fighting was to take place. The colonial authorities, seeing the revolt getting out of hand, directed four companies of colonial troops to tame it. By 1919, Ba Chay had proclaimed himself a messianic leader of the Hmong, raising the stakes to a higher level by playing a powerful and highly sensitive card among his countrypeople, prone to accepting the episodic appearance of Hmong messiahs. The rebellion ended in March 1921 with the killing of Ba Chay by other minority foes in northeastern Laos, notably Lo Blia Yao, a pro-French Hmong leader and father of Laotian Hmong revolutionary hero Faydang Lobliayao. See Culas, Christian. Le Messianisme hmong aux XIX $X^{e}$ et XX siècles. La dynamique religieuse comme instrument politique. Paris: CNRS Éditions, 2005.

${ }^{46}$ Savina, François Marie. Rapport sur la révolte des Méo du Nord Laos. Mission Catho- 
Following his presumed return from Laos in 1921, Savina's name does not immediately re-enter the yearly comptes-rendus. In fact, the next formal mention of him in colonial documents only appears in 1925, when he was sent on another official mission, this time to Hainan Island in China. His whereabouts and the work undertaken between his return from Laos and the year 1925 are not readily evident but again, can be pieced together from various clues provided in his publications. The linguist-cum-ethnographer was definitely stationed in Asia and busy with an intensive writing schedule. Indeed, in 1924 alone, in addition to his Considérations just mentioned, Savina saw the fruition of two of his most important works: his unique 304-page Histoire des Miao, and an even bulkier 528-page Dictionnaire étymologique Français-Nùng-Chinois. As if this was not enough to explain how he filled his time after Laos, these were followed two years later by another piece, the 245-page Dictionnaire Français-Man. ${ }^{47}$ Even by today's computer-assisted standards, such sustained and important production is a remarkable feat, all the more so when one considers that the work was conducted in one of the most remote parts of Indochina with little clerical assistance. Both of the 1924 books were printed in the Mission's printery in Hong Kong, which suggests that, considering the lengthy proof-reading procedure needed at the time, Savina might actually have spent a significant period of time there. Again, a short comment on page 25 in the comptes-rendus of 1925, where his name surfaces briefly, is our best clue: "M. Savina, stopping over in Hanoi," suggesting that the missionary was either just returning to Tonkin, or more likely, leaving, possibly to Hong Kong. Perhaps he was not even in Tonkin, and was only calling at Hanoi on some international journey.

This four year period of unclear movements ends when, from 1925 to December 1928, the Government General of Indochina, with the patronage of École française d'Extrême-Orient, commissioned Savina to undertake a linguistic and ethnographic survey of the vast Chinese island of Hainan off the coast of Tonkin, in collaboration with the Chinese authorities. In favour of his selection for the task, was the fact

lique, Vientiane, 20 p., 1920; Savina, François Marie. "Considérations sur la Révolte des Miao (1918-1921)." L'Éveil Économique de l'Indochine, no. 373, 1924b.

${ }^{47}$ Savina, Histoire des Miao; Savina, François Marie. Dictionnaire Étymologique FrançaisNùng-Chinois. Hong Kong: Imprimerie de la Société des Missions Étrangères, XI-528 p., 1924c; Savina, François Marie. "Dictionnaire Français-Man." BEFEO, vol. XXVI $11-255,1926$. 
that he had already studied and published on some of the languages which, at that time, were believed to be spoken in the hinterland of Hainan such as Miao and Man, while his competence in Chinese was also an asset.

EFEO scholar Paul Mus has encapsulated Savina's venture on Hainan:

Reverend F.-M. Savina went on a journey to Hainan Island that lasted more than four years, crossing it from the north-east to the south-west at its maximum length, traversing the rough central massif in the Governor's company, General Gaston Wong. It was a genuine military expedition, with 150 soldiers. ${ }^{48}$

Clearly, this was a well organised research expedition of international stature, aiming to take stock of the human diversity on the island, for purposes left untold but that were probably strategic in nature. While it cannot be presumed that Savina was concerned with the strategic side of this expedition, he certainly played the role of a scholar actively involved in an administrative and military survey. ${ }^{49} \mathrm{He}$ had played that role before.

From this expedition, Savina produced several handwritten reports based on his own observations and data collected during his journey across the island, which have not been published as such and are kept at the EFEO headquarters in Paris. ${ }^{50}$ These include a map, presumably by his own hand, showing the island's hydrography and orography; handwritten notes on the mores and languages of the tribal inhabitants of the hinterland, as well as data on the local economy, demography, and political situation. The missionary also had time during his four-year assignment to write, as the wealth of manuscripts stemming from his stay indicates, a Dictionnaire Français-Man, already mentioned, published in 1926, whilst in the year 1929 alone he released the manuscripts of three new dictionaries, a Dictionnaire Français-Bêe, a Dictionnaire HokloFrançais, and a Dictionnaire Hiai-Ao-Français, each a substantial piece of work, amounting to a rough total of 1500 handwritten pages. ${ }^{51}$ These

\footnotetext{
${ }^{48}$ Mus, Paul. "Review of Savina's 'Monographie de Hainan'." BEFEO, vol. XXX, pp. 436-44, 1930, 436.

${ }_{49}$ This initiative bore similarities with the colonial ethnographic surveys alluded to earlier conducted twenty years beforehand in Upper Tonkin, also backed by EFEO, under commander Lunet de Lajonquière.

${ }^{50}$ EFEO documentation centre in Paris, under ME 88 (five volumes).

${ }^{51}$ Savina, François Marie, Dictionnaire Français-Bêe, suivi d'un lexique Ong-Bêe-Français. Unpublished manuscript of 335p., [later published by André Georges Haudricourt
} 
dictionaries were above all works of practical interest taking the form of listings of vocabularies in several languages, with little background explanation and no general introduction. They were presumably produced to meet the needs of the French and Chinese authorities who had commissioned the research. Why the EFEO did not actually publish all these dictionary manuscripts remains unexplained. And on top of all this linguistic work, Savina also produced a 59-page Monographie de Haïnan published by the Cahiers de la Société de Géographie de Hanoï, which we will shortly look at in more detail. ${ }^{52}$

His work in Hainan completed, François-Marie Savina returned to Tonkin in 1929. By that time, the multilingual viaggiatory had reached the venerable age - by missionary standards - of fifty-two. At a time when the recruitment of new missionaries was at its lowest, and when all able bodies were needed to carry on the burden of evangelizing, Savina returned to missionary life in the Upper Tonkin vicariate. At his request, ageing Bishop Ramond agreed to attach him to a Miao area. Chapa was by that time a thriving summer hill station for wealthy colonists, and that is where Savina received the mandate to resume his apostolic work. Probably expected to provide religious services to the European and Kinh population of the station, ${ }^{53}$ he was given the charge of the MEP's new mission house, a summer house-cum-chapel built for the use of the vicariate's missionaries in need of a rest. Yet it appears that Savina wished instead to stay away from the crowd, preferring to settle some 40 kilometres down the Muong-bo valley in a minority village.

Savina had returned from Hainan "with a small fortune," ${ }^{54}$ but within a year he had spent it all on his Chapa mission. He had a small wooden church-cum-school erected in his village and lived a secluded life at a comfortable distance from the colonists. Europeans in the station nicknamed him the 'hermit of Muong-bo,' his converts called him Cha Vinh, 'Father Vinh' in Vietnamese, a clever euphonic short for Savina. In the comptes-rendus, where he reappears in 1930, we can learn that:

as Le vocabulaire bê de F.M. Savina, Paris: EFEO, 170p. 1965], 1929a; Savina, François Marie. Dictionnaire Hoklo-Français. Unpublished manuscript of over 1000p., 1929b; Savina, François Marie. Dictionnaire Hiai-Ao-Français. Unpublished manuscript, 1929c.

${ }^{52}$ Savina, François Marie. Monographie de Hä̈nan. Cahiers de la Société de Géographie de Hanoï no. 17, Hanoi: Imprimerie d'Extrême-Orient, 59p. 1929d.

${ }^{53}$ In those years, Chapa had a permanent population of around 1200 (including over 100 permanent troops), plus around 800 additional visitors over summertime.

${ }^{54}$ Obituary 1949, in comptes-rendus pp. 181-3. 
In the Chapa region, M. Savina works courageously to convert the Meo and Man in the mountains. [...] Our colleague lives among them to know them, but he is the only one to understand and speak their language; he needs reinforcement to succeed in his work. ${ }^{55}$

On rare occasions during this posting, Savina's name appears in administrative records, for instance when advocating in favour of the Meo to help settle local disputes with the colonial authorities. ${ }^{56}$ Yet again, in spite of sparse resources and near-total isolation, Savina managed to produce another dictionary, his Lexique Day-Français, published in the Bulletin of the EFEO in $1931 .{ }^{57}$ The same year, thanks to the impressive volume of work he had accomplished by then and in recognition for the work accomplished in Hainan under EFEO's patronage, Savina was made a correspondant, an associate member as it were, of that learned institution.

Four years later, in 1933, due to ill health, Savina was sent back to France for a cure, visiting for the first time in thirty-two years. A year later, he was back in Asia. However, this time he bypassed Tonkin altogether and travelled directly to the MEP publishing house in Hong Kong where he settled for five years. Now on his mind was the task of completing his most ambitious work yet, his last one, a multilingual Guide linguistique de l'Indochine. ${ }^{58}$ Aged 60, not unlike a medieval monk, Savina spent half a decade bent over this huge, 2500 page oeuvre. In 1939, his task completed, he returned for the last time to field work in Upper Tonkin. Having been replaced in Chapa by young Jean Idiart-Alhor, who settled there in 1937 and had learned the vernacular languages, Savina was sent to Ha-giang, farther up the Glear River from Vinh-tuy where he had started his active missionary career. That is where he lived for the last two years of his life. In March 1941, falling ill with pneumonia that he did not take care of immediately, he had to be taken to Hanoi for treatment. After four months in St-Paul clinic, he died on 23 July 1941 at age 65, exactly 40 years after he had first set foot in that same city.

\footnotetext{
55 Comptes-rendus 1930, p. 163

56 "Résidence de Lao Kay: corvées et impôts; mécontentement des populations montagnardes (Meo, Man), intervention du père Savina: correspondances, rapports, enquêtes." CAOM, RSTNF 7022, 1931-1932.

${ }^{57}$ Savina, François Marie. "Lexique Day-Français accompagné d'un petit lexique Français-Day et d'un tableau des différents dialectes." BEFEO, vol. XXXI, pp. 103-199,

${ }^{58}$ Savina, François Marie. Guide linguistique de l'Indochine française.
} 1931 . 


\section{The disciplinary hypothesis}

At least, this is how the synopsis of the biographical information available on Savina looked in 2003 when I had initially completed researching this section. However, in Spring 2004, when investigating again the MEP archives in Paris, I came across new material that revealed new events which had a decisive impact on Savina's career as a MEP missionary and on his performance as an ethnographer.

The evidence, contained in copies of four letters kept in Bishop Ramond's papers, one sent by Ramond to Savina in 1931 and three sent two years later to a fellow, unnamed colleague, likely another Bishop, points to the fact that Savina had to be regularly removed from his field postings due to his contravening of his religious vows. If we accept the information contained in Ramond's letters, we can attempt to reconstruct Savina's whereabouts according to this novel information, give and take a few inconsistencies possibly due to Ramond's failing memory of events long gone, or the spontaneous character of his letters.

Savina arrives in Hưng Hoá in 1902 and during the first two years there, shows the first signs of not taking his religious promises as seriously as he ought. Narrowly avoiding being removed to Hong Kong, he is sent instead to assist a colleague somewhere else in the Upper Tonkin vicariate, probably in a Kinh area not far from Hưng Hoá. After over a year, he is then judged fit to set up his own mission. This leads to his 1906 posting to Vinh-tuy. After a few years of being left to himself however, he transgresses the rules again and is removed from that mission in 1911 to be reassigned to a distant one, where he is told to live in the church's presbytery - this could be the town of Lao-kay, perhaps even Chapa. Within a year however, against the clear advice of his Bishop, he has gone to live among the natives (the Nùng or the Miao/Hmong). Ramond then resolves to send Savina to Bishop Bertrand Cothonay, a French Dominican and first prefect apostolic of Lang-son and Cao-bang. ${ }^{59}$ Savina appears to arrive there in the year 1913 or 1914, but a year later, around 1915, he is sent back to Ramond for the same difficulty again. Dispirited, the Bishop of Upper Tonkin decides to deny Savina access to his vicariate and as an alternative sends him to Hong Kong under the responsibility of his colleague Léon

59 The Lang-son and Cao-bang Prefecture Apostolic, detached in 1913 from the Northern Tonkin vicariate, itself split in 1883 from the original 1757 East Tonkin Vicariate, was equivalent to a diocese but was only made Vicariate Apostolic in 1939. 
Robert, director of the MEP head office there. Over the following 10 years, Robert apparently sends Savina - or allows him to go - on a few assignments in Haiphong, Laos (1918-1921), Lang-son, Moncay, and from 1925 to 1929, to Hainan. While he studies languages and writes profusely, it appears that he persists in contravening his congregation's rules. At the end of his Hainan adventure, at the age of 53, it is an apparently regretful Savina who writes to Ramond and asks him to take him back in Upper Tonkin. Ramond is moved, accepts and attaches him to Chapa. But soon, in 1931, new incidences of the same nature shatter the elderly Bishop's last hopes, and Ramond orders Savina out of Tonkin for good, giving him the option to settle back in France or to retire to Hong Kong. Savina does not like what he sees of France enough to stay, so he settles for Hong Kong and devotes himself to his last publication, his enormous multilingual dictionary. That completed, by 1939, aged and ill, he is allowed back in Upper Tonkin by Ramond's successor, Bishop Vandaële, who assigns him to Ha-giang where he dies within 2 years.

Apparently unable to fully fit the mold his missionary organisation expected him to suit, Savina could have left the MEP and priesthood altogether, but chose not to. As was stipulated in its constitution, his society could not expel him against his will. But he could be sidetracked, and that appears to be the course of action chosen by Bishop Ramond. Of interest to us, this undoubtedly became an instrumental factor in his lifelong ability to dedicate his mind and energy to scholarly pursuits. As for his morality, it is not my role to justify or vilify him for his behaviour. Savina clearly appreciated the natives' company, and they probably appreciated his too. To what degree his Hmong, Nung and Tay hosts approved or disapproved of his behaviour, and whether they even disapproved it deeply enough without feeling empowered to denounce or expel him, it is difficult to say. It is very likely though, that had they strongly felt against his presence amongst them, he would simply have been pushed out of his hosts' houses in usual highland fashion.

From the point of view of ethnography, this irregular situation for a MEP missionary in Tonkin, must have contributed to adding value to Savina's writings by making him much more of a participant-observer of highland cultures than more distant European priests.

\section{A word on Savina's dictionaries}

Over 28 years, from 1911 to 1939, Savina published four lexicons and eight language dictionaries totalling over 5000 pages and exploring a 
dozen languages. Each of these dictionaries was, for the most part, based on original data collected by the author himself. Faced with such a wealth of first-hand data from a fairly remote corner of the known world in the early 20th century, linguists who came after Savina have found large portions of his work useful. They have also discarded large segments as unusable by today's more rigorous linguistic standards. As a self-taught linguist, there was only so much Savina could ever achieve, but his was such a massive contribution towards the understanding of several then relatively obscure Asian minority languages that one can only stand in awe of his painstaking work.

Savina's linguistic work was well received during his time. His first dictionary, published in 1911 ten years after his arrival in Tonkin, the 500-page Dictionnaire Tay-Annamite-Français, précédé d'un précis de grammaire Tay et suivi d'un vocabulaire Français-Tay, was by far the most important work ever produced by a European author on Tay language in Vietnam. Accordingly, this work swiftly received recognition by way of the Stanislas Julien award from the French Académie des Inscriptions et Belles-Lettres - in 1912, one year after Vial — a feat he repeated in 1925 when he won the Giles award from the same institution for his 1924, 540-page Dictionnaire Étymologique Français-Nùng-Chinois. ${ }^{60}$

His second work, the Dictionnaire Miao-tseu-Français, was published in 1916 in the Bulletin de l'EFEO, an outlet which in itself constituted an explicit acknowledgement of Savina's scholarship. This dictionary was immediately praised by specialists as a significantly more complete work on Miao/Hmong language than anything published before, including Paul Vial's French-Miao-tseu lexicon of 1908, a work which, despite its brevity, had merits. Substantially larger at 200 pages, Savina's dictionary contained an introduction about language mechanisms, phonetics and tones, and a French-Miao-tseu vocabulary, each placed at opposite ends of the text formed by the dictionary itself. To the benefit of later anthropological research, Savina provided, in this publication, expressions and examples attached to each entry, with Chinese ideograms whenever appropriate, thus painting a vivid, multi-lingual picture of Miao life as he saw it. He also designed an original way of writing Miao using quốc ngũu, adapted to account for specific features of Miao. In 1921, the Dictionnaire Miao-tseu-Français was deemed by EFEO scholars

${ }^{60}$ Savina, François Marie. Dictionnaire Tay-Annamite-Français, précédé d'un précis de grammaire Tay et suivi d'un vocabulaire Français-Tay. Hanoi: Schneider, XV-488, p. 1910; Savina, Dictionnaire Étymologique. 
as an essential tool for ethnographic classification based on linguistics, for all of northern Indochina and southwest China. ${ }^{61}$

In his Dictionnaire Français-Man, published in 1926 in the BEFEO again, Savina once more adapted standard quốc ngũ to record variants of the Man (Yao) language, a sub-group of the Miao-Yao language category. The main body of the text, abounding as usual with contextualised vocabulary, was preceded by a note on Man society based partly on the author's direct observation, notably on Hainan Island where he completed this publication. Then, Savina's three new dictionaries and lexicons stemming from the Hainan survey together formed an impressive set. While the Dictionnaire Hoklo-Français (1929b) was concerned with the island's Chinese majority inhabiting the northeast lowlands and all the coastal areas, his Dictionnaire Français-Bê, suivi d'un lexique OngBê-Français (1929a) focused on Tai-speakers dwelling in the northwest of the island. His Dictionnaire Hiai-Ao-Français (1929c) addressed the language of the original indigenous group of Hainan who had been pushed up into the mountains by later migrants. These three groups were totally different cultural entities with barely related languages, all documented by a self-taught missionary-cum-linguist. ${ }^{62}$ In 1931, the BEFEO published Savina's Lexique Day-Français accompagné d'un petit lexique Français-Day et d'un tableau des differents dialectes, a less substantial piece than earlier works and one which, essentially, was meant to be used in the field by missionaries and administrators dealing with Tai-speaking groups in Tonkin and southern Yunnan. ${ }^{63}$

With thirty odd years already spent in Asia, Savina then undertook his magnum opus, the 2500-page, eight-language Guide linguistique de l'Indochine, published in 1939 after five years of work in Hong Kong. Savina wrote its two volumes largely from his own notes, summarizing his accumulated knowledge and collecting additional documentation only on languages that he was less familiar with. It is a work of comparative philology between the monosyllabic languages of Asia, namely Vietnamese and Vietnamese Chinese, Tay (Tho), Man (Yao), Miao

61 Savina, Dictionnaire Miao-tseu-Français. Cf. Collective. "Ethnographie indochinoise." Synthèse collective à l'occasion du $20^{\mathrm{e}}$ anniversaire du BEFEO, vol. XXI, pp. 167-196, $1921,193$.

${ }^{6}$ Savina, Dictionnaire Français-Bê; Savina, Dictionnaire Hoklo-Français; Savina, Dictionnaire Hiai-Ao-Français; Savina, "Dictionnaire Français-Man."

63 Savina, François Marie. "Lexique Day-Français accompagné d'un petit lexique Français-Day et d'un tableau des différents dialectes." BEFEO, vol. XXXI, pp. 103-199, 1931 . 
(Hmong), Cantonese, Hoklo, and Mandarin. The dictionary comprises 20,000 French words translated into all, or most of these languages, using a Romanisation based on quốc ngũ , as well as Chinese ideograms. Unavoidably, due to its sheer size and scope, this latest publication duplicated various earlier dictionaries. Nonetheless, the accomplishment of integrating all this data and contextualising the vocabulary in each language into one book is extraordinary. ${ }^{64}$

Savina's dictionaries are a source of ethnographic information in the form of comparative lexicons and short introductions about specific groups. This material still waits to be systematically explored and exploited. Exactly how much can be learnt about the highlanders of Indochina from these thousands of pages is very much open to conjecture. Their descriptive quality as first-hand ethnography, conducted over many years by a linguistically skilled observer, can not be underestimated.

\section{Savina's ethnographic publications}

Two of Savina's publications are of unambiguous ethnological character. His short Monographie de Hainan, first, was his only published work of an explicitly ethnographic nature.$^{65}$ Its wide scope - three unrelated linguistic groups - combined with its modest size - 59 pages of which only 46 are actually devoted to ethnological considerations - means that it stops short of being a major study. Those 46 pages actually formed the substance of a talk that the returning missionary gave to the Geographical Society of Hanoi on 10 December 1928, in which he drew for his learned audience a demographic, economic, linguistic, and political sketch of Hainan Island's coastal population, including brief notes on the customs and traditions of the populations living in its highlands. Paul Mus, who thought highly of Savina the "unrelenting worker," rightly noted that the booklet Savina drew from for this talk provided interesting material in terms of comparative linguistics. ${ }^{66}$ But in ethnological terms it could hardly be seen as anything more than an overview, not giving full justice to its author's four years of work there, nor to the cultural diversity present on the island at the time of his survey.

${ }^{64}$ Savina, Guide linguistique de l'Indochine française.

${ }^{65}$ Savina, Monographie de Hainan.

${ }^{66}$ Mus, "Review of Savina's 'Monographie de Hainan'”, 443. 
But the second of Savina's two ethnological publications, the one in which he includes his most substantial ethnography, and the only one among all his publications where he indirectly provides information on his methods and intellectual position, is his celebrated 1924 Histoire des Miao, by far his most widely quoted work today ${ }^{67}$

\section{Inside Histoire des Miao}

First, a few observations to situate the text. At over 300 pages, more pages than any other monograph on a given highland people ever produced in colonial Indochina, Histoire des Miao was an ambitious project. Over the twenty-three years that he had already spent in Tonkin at the time of its publication, Savina had had the opportunity to develop a special relationship with the Miao, also called the Méo or Hmong, the latter being their genuine autonym as Savina rightly acknowledged. Prior to disembarking in Tonkin, he had not received any preparation for this kind of exotic encounter, let alone for its scholarly consideration. In Histoire, he declared "I did not go among the Miao to solve [academic] questions, as I was already among them when I started thinking about them." ${ }^{68}$ Thus, once in Upper Tonkin, Savina spent substantial periods of time in the company of the Miao. It was what he perceived as their great antiquity that stimulated his curiosity.

A race with fifty centuries of history has a right to be called an old and respectable race; for if old age makes individuals venerable, and if a great ancestry makes families honourable, a great antiquity also makes peoples interesting. ${ }^{69}$

As Savina constructed it, his ethnography was obviously meant to be a bold statement of his personal vision, yet it had a resolutely scientific feel to it. He did not give his prose the form of a diary, nor did he follow a time narrative. The divisions of the book actually expose the author's vested interests. In the first chapter - 'Comparative Study of Miao language' - Savina explains that linguistics is fundamental to understanding a people. In Chapter Two - 'The Miao in History'- he adds that historical surveys are also crucial and he proceeds to situate the Miao in the context of World and Asian history. This is followed

67 Savina, Histoire des Miao.

68 Ibid., x.

${ }^{69}$ Ibid., vii, 284. 
by two chapters devoted to ethnographic description - the 'Miao at Home' and 'Beliefs of the Miao'. ${ }^{70}$ The main body of the text ends with an 'Appendice' in which the author briefly discusses the future of the "Miao race".

The emphasis put on the central importance of linguistics and history to study human groups was typical of the study of the exotic Other at the end of the 19th century, and Savina never ventured far from that position. Arguing for his idea of what the best research tools to use in this endeavour, were he first stated that the proper way to start a study of a population such as the Miao should be lexical comparisons between neighbouring groups. He firmly believed in language as a classificatory tool, more so than biology - or race as he put it - which he saw as being the tool of "ethnologistes," thus somehow ruling himself out of that category. As for history, Savina believed it was especially important to attempt going back in time as far as possible in search for the primeval Man. Expectedly however, his view of history was Eurocentric, rooted in French civilization and in the Catholic tradition. His Biblical biases in particular, while not explicitly expressed on every page, were never far and led him to more than one unwarranted generalization, as we will see.

Unlike the dominant academic position in nascent French anthropology at the time, which still favoured working from secondary sources, Savina, as Liétard and Vial before him, also believed in the importance of becoming directly involved in the observations of his subjects in situ. In terms of the data required to write his Histoire, it is a fact that Savina himself gathered the vast majority of the field data that he used. As far as can be ascertained from analysing the available manuscripts - though I have not been able to find the original, pre-publication manuscript of Histoire - his field data took the form of notes containing quotes in

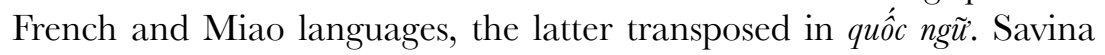
probably used the Miao language as well as Vietnamese to conduct his interviews, and possibly some French when discussing with native converts educated in a mission.

As for the texts used to support his analysis of the data, these had visibly been selected with a purpose in mind, though it is doubtful

${ }^{70}$ In the original text, respectively: 1. Etude comparative de la langue Miao; 2. Les Miao dans l'histoire; 3. Les Miao chez eux; and 4. Croyances des Miao. 
that purpose was the critical scientific consideration of the facts. Savina handpicked the arguments that he needed to support his thesis. Furthermore, he sought complementary guidance from likeminded persons who he trusted, that is, fellow missionaries and on occasion, a few scholarly collaborators he had met in Indochina. After processing his data, Savina constructed his text in a manner typical of the missionary condition, that is, with a leaning towards empirical thinking. He used a mixture of subjectively selected scientific arguments often randomly blended with direct observations and personal appreciations, and produced a discussion in which he, as the author, often boldly took the front stage, allowing his impressions and emotions to consistently mingle with more rational deliberations.

These reservations expressed, Savina was nevertheless surprisingly well-read for a rank and files missionary who very likely had not had much education in science and no easy access to the latest ideas and debates of the time or to good libraries. The written sources he drew upon were largely from the second half of the 19th century and were predominantly in French, with some in English too. ${ }^{71}$ We will come back to this point.

Despite the apparently sound structure of Histoire, when proceeding through the book, one develops a growing sense of a piecemeal work. Scholarly sub-sections that include extensive quotes of well and less well-known scholars, and the weighing of their arguments, are sometimes immediately followed by devout considerations of the Old Testament, by quotes from Brittany's folk songs, or poetry improvised by the author on the occasion of story-telling evenings in Miao houses. To put it mildly, the relevance of using peasant traditions from Brittany and poetic licence to explain the Miao vision of the world raises reasonable doubts, not least because all of this material is indiscriminately brought to the same level of scientific pertinence. This appeared to constitute, in Savina's mind, the rightful substance for a comparison that would in turn lead to an explanation. ${ }^{72}$ The fact that Savina was brought up in a rural setting and understood its logic, proved at once useful and tricky. His own rural habitus allowed him to enter the Miao

${ }^{71}$ This fact suggests that he had been able to learn at least a rudimentary form of English before 1924, possibly while at the MEP Maison Nazareth in Hong Kong.

72 Or, slightly mischievously, one could also take note that Savina showed an early post-modernist sensitivity towards assigning equal value to the blended, multiple voices of the author and his subjects in writing his ethnography. 
universe much more deeply than would have been possible if he had come from an urban middle-class background, or if he had been a military officer with a patrician upbringing. Savina could relate to his subjects with special empathy, and share the peasant soul of the Miao. That empathy is illustrated by the poetic essays interspersed throughout the book, all illustrating a sense that the author shared a common perspective on Nature and on Man with 'his' Miao - be this a real or imagined community.

It is informative to consider in more detail the substance of Histoire des Miao and attempt to decipher it as discourse. In an eleven-page preface opening the book, the author introduces the Miao and briefly reviews the literature on Indochina and China which failed to account for that group. Then, wishing to place the book within a lineage of related studies, Savina locates it in the direct line of Mission D'Ollone 1906-1909 recounting Henri D'Ollone's land expedition from Tonkin to northern China. ${ }^{73}$ Significantly, D'Ollone had declared that his objective was to assess who the indigenous, non-Han peoples of southwest China were, and exactly how antique they might be. In this regard, the affiliation of Savina's monograph with this earlier text is understandable. On the other hand, D'Ollone's books bear only modest resemblance with Histoire des Miao and in fact, they show a much more limited ethnological concern. In choosing such intellectual patronage, what also surfaces is the conspicuous absence of numerous other authors Savina could have elected instead as his models such as Pavie, Lefèvre-Pontalis, or colleagues like Vial, Liétard or Schotter. ${ }^{74}$

In the preface, Savina explains his endeavour as:

a search to find what is the Miao race, how long it has been in China, by which ways it has got there, where did it come from, where was it born, and which family, in anthropological and linguistic terms, should it be connected to. ${ }^{75}$

${ }^{73}$ D'Ollone, Henri. Écritures des peuples non chinois de la Chine; Quatre dictionnaires Lolo et Miao Tseu. Mission d'Ollone 1906-1909. Paris: Ernest Leroux, 1912a; D'Ollone, Henri. Langues des peuples non chinois de la Chine. Mission d'Ollone 1906-1909. Paris: Ernest Leroux, 1912b.

${ }^{74}$ However, Savina dedicated Histoire des Miao to André Kircher whom we met briefly earlier in this chapter, former secretary of Paul Vial in Lon-gny-tsin, who spent 11 years among the Miao in Yunnan and had just died at the time the manuscript of Histoire des Miao was completed. But explicit reference to Kircher are otherwise absent from the book.

${ }^{75}$ Savina, Histoire des Miao, x. 
The preface actually contains samples of all the ingredients which will characterize the book. The author declares his preference for oral tradition over written text. ${ }^{76} \mathrm{He}$ voices his faith in the comparative study of languages, history and customs. He presents the Miao as being a unique people. ${ }^{77}$ Their historical existence in China, he believes, predates that of the Han. He speculates on their past as "primeval humans", and to clarify their origin, he narrates a Miao myth with quotations in the vernacular language interspersed with roundabout Biblical references. He also quotes in full a folk song from his childhood. All these elements and markers of the author's personality and cultural location, recurrent throughout the book, profitably inform us about his intellectual processes.

Finally, in the closing paragraphs of the preface, Savina provides a concise summary of his methodological views based on linguistic and cultural comparisons and historical analysis:

An in-depth study of a people's language, history and customs unavoidably leads to the same study among other peoples. This is the reason why in the three chapters of this book devoted to the language, history and customs of the Miao, I also talk about the languages, history and customs of their neighbours.

In order to find a solution to linguistic, ethnographic, historical and religious problems, we must indeed go back to the origins; and we cannot go back to the origins without conducting successive analyses and comparisons. Single studies, or monographs, never solved this type of question. Monographs are like isolated blocks of rock; in order to discover the vein where these blocks originate from, we must at times take a distance. $[\ldots]$

Such is the case with these problems. To find a solution, we must go back to prehistory and, with successive analyses, get ever closer to primitive type, family, language, and religion. ${ }^{78}$

${ }^{76}$ On the origins of the Miao, Savina declares: "The answer I had sought in vain from the Chinese annals, historians, linguists and ethnologists, Miao traditions gave it to me." Ibid., x.

77 The oft quoted first sentences of the Preface encapsulate Savina's obsession with uniqueness: "From time immemorial there exists in China a human race whose origin is unknown. Constantly living in the uplands, remote from all other Asians, these men speak a particular language unknown to all who surround them, and wear a special costume that can nowhere else be seen. [...] Their physical features are also different from those of all other races in Asia. [...] In religious terms, they differ from all their neighbours." Ibid., vii.

${ }^{78}$ Ibid., xvi-xvii. 
Inserted between the preface and the first chapter comes a short technical presentation of Miao language. Beyond its evident practical function, this insert reinforces the impression of scientific treatment and helps establish the author's credibility. Here, Savina exposes pronunciation particularities and tone rules, and provides details regarding the transcription in this work, a system based on the Romanisation of the Vietnamese language that he adapted for his 1916 Miao dictionary.

The first chapter, titled 'Comparative Study of Miao language,' deals with issues pertaining to linguistics. Here Savina expresses two objectives, namely to classify the Miao language among other Asian languages, and to locate the Miao people among other peoples of Asia. These two distinct, yet largely overlapping goals entail the need for the author to present and discuss other languages and peoples. The first section of the chapter presents a selection of Miao vocabulary selected according to their antiquity and commonness. Words are clustered into nine thematic groups - numerals, the body, family, flora, and so on - with a partial contextualisation of their use. After this listing comes a 27-page synoptic table presenting over 250 selected substantives and their counterparts in ten different languages. While no reason is given to justify that selection of languages, a quick inspection shows that for those idioms that he did not know himself, Savina's choice was based on his network of fellow missionaries acquainted with these languages, completed with a few written sources. The ten languages presented in the table are Miao (Hmong), Man (Yao), Thai, Vietnamese, and Chinese, all reasonably mastered by Savina, plus Lolo, Thibetan, Tatar, Malay and Stieng for which he relies on the works of others. Peculiarly, and quite impractically, no European language is included in his synoptic table, not even French. This difficulty is further compounded by the fact that following the table, no analysis is made and the author directly proceeds to the next section. The self-taught linguist here, one has to conclude, is hardly meeting his objective of "classifying the Miao language among other Asian languages."

Savina devotes the rest of this first chapter to his second objective, discussing the possible classification of the Miao among other Asian groups. In what could be considered his literature review and most theoretical section, Savina introduces other authors to help him summarise general notions of ethnography and linguistics, to discuss the concept of "human races", and to try to answer the question of locating the birthplace of the human species (l'espèce humaine). He however concludes 
that the types of classification suggested by these scholars are of little help because academic considerations are insufficient for the complex task he has assigned himself. Additional action is required. Savina thus discards the approaches and methods he has found in ethnology books, before suggesting his own solutions:

This sketchy information is absolutely insufficient to classify these peoples. Their current habitats do not inform much on their former ones or on their migrations; their physiological characteristics leave us in the dark too, leaving in doubt their respective origins and their various degrees of kinship. Ethnology does help in the classification of peoples. But due to ethnic blending, it remains, except for the broad lines, incomplete and uncertain. It is therefore necessary to provide it with some assistance.

To succeed in classifying one given people, it would first be necessary to know its antiquity, its primitive geographical situation, its migration routes and the degree of kinship with its neighbours, its history, its traditions, its beliefs, its current as well as its original languages.

But knowing all that is impossible. We cannot pinpoint the exact origin of any given people because no people has been writing it down from its very origin. The memory of peoples, like that of men, talks eloquently about its cradle when it comes to write about it. But we must not forget that these texts are written when these peoples are, as it were, in old age.

In any people's annals, the first pages always go missing. They are replaced by the extra sheets of legendary traditions, and these are always disputable. ${ }^{79}$

Faced with such predicaments, Savina assesses that a safer way forward is the study of religion:

Religious beliefs are more precise. They constitute the only truly historical document about primitive, or pre-Flood, humanity. By gathering and putting together the beliefs of all peoples regarding primitive times, it would become easy to reconstruct the great events mentioned in the Genesis. But these beliefs were all lost in the post-Flood generations. ${ }^{80}$

Primitive memory forever gone, language thus offers the only solution:

Ethnology being uncertain, history lacking completely, traditions being unsure, primitive beliefs being gone with the first generations of humanity, we have to count on something else to reconstruct peoples' earliest times. Only their tongues are left. ${ }^{81}$

\footnotetext{
79 Ibid., 87.

80 Ibid., 87.

81 Ibid., 88.
} 
Savina firmly believes that due to the advanced state of human interbreeding, ethnology alone can not produce an exact classification of the human species. Ethnology, he declares, has only been capable of classifying various peoples according to race, family and tribes. It has failed in identifying their "primordial types," their essence. In fact, according to Savina, from the moment the last of the original tribes abandoned the site where Man first appeared - this is the monogenist speculation - no truly indigenous peoples were left, only colonists.

Thus equipped, how successful is Savina in classifying the ten groups he has selected? In summary, his conclusion is that the Miao, the Man, the Lolo, the Tatars and the 'Thibetans' all came from the north, probably Siberia. The Chinese, Malay, Vietnamese, Thai, and Stieng came from the south, more precisely from India, their idioms having derived from a common Dravidian stem. His final opinion on the Miao, the centre of his attention, then takes a quantum leap: he connects them straight to Biblical times and peoples. He argues that Miao history perfectly parallels Biblical narrative and is nearly identical to Chaldeian cosmogony. He states that only the latter, along with the Armenians and the Miao, have kept the memory of Babel alive, and its associated confusion of languages followed by the dispersion of peoples on the face of the Earth. From there, he needs only one more step to boldly declare that the linguistic bridge connecting the Miao with Siberia only masks the truth, which is that before their Siberian episode, "the Miao must therefore be considered as having their primitive habitat on the shores of the Tigris and Euphrates." And finally it is a quasi-ecstatic Savina who drives the last nail: "The Miao man can stand up, upon listening to the first chapters of the Genesis, and say: It is true, I was there!" 82

Visibly, the first chapter of Histoire des Miao is the weakest one in the whole book. Despite putting together scholarly sources and potentially exciting linguistic data, it is the most speculative chapter, and the one that can less stand scientific scrutiny. In spite of a genuine effort to tackle a difficult ethnohistorical issue through language, the Miao possessing no written language or archives, the only goal Savina undeniably achieves is to expose beyond any possible doubt the shortcomings of his 'science.'

${ }^{82}$ Ibid., 103, 104. 
Chapter Two, 'The Miao in History', stands more steadily despite the fact that here again, Savina's fascination with the Bible taints his interpretation of Miao oral history. Having by now situated their earliest point of origin in the Middle East and well aware that none of them can be found there nowadays, he moves on to search for a migratory route. His hypothesis is that the antique Miao first went across unidentified high mountains (Tibet? Hindukutch? Ural? he suggests) to reach northern Siberia beyond the 60th parallel. ${ }^{83}$ This Nordic journey, he reckons, is confirmed by the oral tradition of all the Miao groups he has visited, each recounting the story of an ancient settlement 'beyond the back of China' where there was snow and no forest, and where nights and days lasted for six months each. Then, around $2500 \mathrm{BC}$, the Miao moved south and east to finally settle in today's Hunan province in China. At this point, Savina briefly addresses the methodological issue of whether we should listen to such traditions and believe in old stories passed on from one generation to the next. His answer a contratio is that science simply cannot afford not to: "Knowing little as we do of all that concerns primitive humankind, we must stand at the door of the Past and listen with respect to all echoes reaching us from there." However, resorting again to warped rhetoric, he states on the same page: "Their tradition on this point [their migration] is formal and universal; there is no reason not to believe it." ${ }^{84}$ Indeed, in his mind, a lack of evidence is not enough to discard mythological history; on the contrary, it can be received precisely because there is no contradicting evidence either.

Coming back to some degree of rationality, Savina then proceeds to cross-check the information he has obtained through Miao oral history with Chinese sources. He produces a sizeable chronology of ancient Chinese history according to secondary sources, his point being to demonstrate that the arrival of the Miao in the Yellow River basin preceded that of the tribes that were to become the ethnic fabric of the Han. From page 127 to page 165, he assembles all the direct references to the Miao in Chinese sources, most of the time extracting his information from publications by European authors in French, English, German and Latin. He sometimes quotes directly from Chinese documents too, which we have to assume he has read. Again, speculation runs high

83 Ibid., 116-117.

84 Ibid., 117. 
in this section. For example, Savina takes the ethnonym 'Miao' at face value and attributes to it a uniform and unchanged substance through the ages, a basic mistake often denounced by later authors. ${ }^{85}$

Like many among his colleagues stationed in the Southeast Asian massif, Savina also appears protective of his Miao, and biased against the Han. He spends the last four pages of his historical chapter voicing reservations and disagreements about Chinese sources on the non-Han peoples in the southwest. His point is to denounce the partiality of the Chinese against all 'barbarians' that transpires in the Chinese sources used by European authors. He rightly notes that most European authors did not speak "the Miao language", had not conducted studies among them, and, being historians or otherwise preoccupied with official history, had little interest in marginal tribal groups like the Miao.

Yet overall, for the less informed reader, the general sense after reading this second chapter is that of a great antiquity of the Miao seen as a cultural monolith, their long march from the Middle East, and the fierce resistance with which they opposed assimilation by the Han Chinese coming to dislodge them from the fertile lands. This romanticized vision of the Miao, which Savina contributed to popularise, is still uncritically accepted and repeated today by some non-academic authors. It is, however, considered by scholars as being totally invalid. One should be wary of accepting just about any element of Miao history as seen through Savina's eyes. The myth of Miao origins, however, is genuine and is still passed down from one generation to the other, and for this record at least, Savina has left a valid and important document.

So far, based on these first two chapters, Histoire des Miao makes a somewhat disappointing read. It lacks intellectual foundations and appears to be just another example of a sketchy, Eurocentric essay by a missionary indulging in amateur ethnography and eager to bring 'his' converts to the attention of the world. Had Histoire stopped here, it would certainly, and rightfully, have fallen into oblivion, except perhaps as a source of eccentric quotes. Fortunately, in the second half of the book, Savina leaves the realm of speculation, semi-digested academic readings, and half-baked hypotheses to present his most

${ }^{85}$ In particular by Lombard-Salmon, Claudine. Un exemple d'acculturation chinoise: la province du Guizhou au XVIII siècle. Paris: École française d'Extrême-Orient, vol. LXXXIV, 1972; Culas, Christian and Jean Michaud. "A contribution to the study of Hmong (Miao) migrations and history." In Hmong/Miao in Asia, ed. by N. Tapp, J. Michaud, C. Culas, G.Y. Lee. Chiang Mai: Silkworm, 61-96, 2004. 
valuable contribution to the ethnology of the Miao/Hmong: well-rooted ethnography.

Called 'The Miao at home', the third chapter is authentically ethnographic. Savina abandons documentary sources to rely on personal observations and experiences of the actual Miao as he met them over the years. He safely limits his discussion to the groups that he lived amongst and to regions he actually visited. In short, as he explicitly points out on page 173, Chapter Three refers only to matters that he himself witnessed.

'The Miao at Home' is above all descriptive ethnography, but it also includes opinions, hypotheses, and impressions. The exposé starts with a depiction of Miao habitat in which Savina gives endogenous explanations on why they choose to settle in a particular environment. Here, and in a later section, ${ }^{86}$ Savina describes agricultural practices, produce, cattle, diet, timber extraction and processing, as well as the gathering of forest products. He explains the Miao customary system of land tenure and describes market-oriented activities and marketplace trade regarding particular products. He presents the village layout, house clustering, building techniques, and describes house furniture. Next, he discusses the migration process together with how the choice of a new village location is made, tree planting techniques, and clanic association. Economy and domestic life are also presented with a focus on animal raising, while opium growing is mentioned parenthetically. An exploration of Miao notions of hygiene and health - or the lack of - follows, with an insistence on the sanitary benefits of living in high altitude dwellings. Here, Savina expands on political considerations based on upland-lowland dichotomy and antagonism and insists on the necessity for the colonial state to firmly ally with upland peoples to counter what he considers to be pervasive and ominous Chinese influence on the borderland of Indochina. ${ }^{87}$

The next section in this chapter considers the aesthetic appearance of the Miao, that is, clothing and personal ornaments: materials, modes of fabrication, uses, and so on. This is followed by rituals surrounding funerals, weddings, births, naming babies, New Year, fishing, and hunting. The closing section, 'Mores and Character', praises Miao hospitality, their bravery and courage, their love of freedom, and the near-absence

${ }^{86}$ Savina, Histoire des Miao, 213-222.

${ }^{87}$ Savina, Histoire des Miao, 206. 
of theft. All the same, Savina also decries their cruelty at war, their occasional laziness and carelessness, and some "inconveniences" caused by excessive alcohol and opium consumption.

In Chapter 3, Savina described what he saw with noticeable sympathy for his subjects. But he still did so from the perspective of an outsider. This combination authorizes him to portray behaviours and attitudes that would likely have gone unnoticed to most observers or indeed to the subjects themselves: the warmth of the welcoming ritual, the lively evening discussions around the fire, or the enthusiastic outpourings at singing contests. It is precisely on this subject of singing that Savina remarks on the importance of searching oral tradition, which he aptly calls the "literature of the Miao," as a vehicle for learning about customs. He points to the crucial importance of mastering the vernacular language to access the rich deposit of information only accessible by this means.

Finally, the fourth and last chapter of Histoire tackles the 'Beliefs of the Miao'. Savina remains consistent here with his earlier statement regarding the potential of religion as a repository of primitive messages from the early Man, though he is not quite in step with his own verdict that such a receptacle had been drained after cataclysmic Biblical events. ${ }^{88}$ In this chapter, Savina wants to trace the origin of Miao religious beliefs as far back in time as possible, and compare these beliefs with those of other civilisations. He writes that "after trying to situate the Miao on the linguistic, ethnographic, and historical map of Asia, we will now try to place them on the religious map of the world." 89 He had actually stated 55 pages earlier what makes this comparative strategy necessary, once more bringing to the forefront the monogenist model. He declared:

Of all human types in existence on the globe at the moment, the Miao type is probably the one that has changed the least among peoples with comparable historical longevity, and could well be, because of that, the one closest to the primeval type of humans..$^{90}$

Savina first develops this argument by presenting Miao beliefs in general, before turning to what he calls their religion, their morality, and

\footnotetext{
88 Ibid., 87.

89 Ibid., 243.

90 Ibid., 188.
} 
their rites. The main body of his data consists of myths chanted to him around 1915 in an unspecified location in Tonkin. Savina transcribes these chants verbatim in the exact order that they were sung to him, adding separate comments in occasional footnotes. Operating this way, he provides an account of Miao myths as they appeared in oral tradition a century ago, though of course mediated through his memorisation, transcription and translation. These myths he liberally titles 'The Creation of the World', 'The Creation of Man,' 'The Great Flood', 'Babel Tower and Confusion of Languages and Dispersion of Peoples', and 'Death and Future Life. ${ }^{91}$ Despite the headings, Savina's transcriptions of these myths do not explicitly mention the Great Flood or the Babel Tower as recorded in Semitic tradition. They refer in fact to $a$ flood, and to $a$ giant stairwell. Yet again, Savina can simply not resist the temptation to merge these stories with his own presumptions.

He begins his discussion of Miao religion with a definition of 'religion' he borrows from Le Roy's La religion des Primitifs published in 1909, a copy of which could probably be found in MEP circles. ${ }^{92}$ This expression of intellectual rigor - actually referencing a particular notion - is in itself unusual for most missionaries in the field. In those days especially, one might have expected that an experienced apostle of God would not feel the need to define a familiar, quasi-immanent notion such as 'religion'. It is actually the first time in the whole book that Savina defines at all a concept that he intends to use. This does not occur, for instance, when he discusses notions of race, nation, tradition, mores, or kinship. What exactly motivates him to do so here remains unclear, but the topic of religion being closer to home so to speak, it was more likely to be the target of criticism from other clerics reading Histoire. Savina perhaps needed to find some intellectual shield in his arsenal to deflect prospective criticisms.

His preferred definition of religion thus comprises the three dimensions of belief (la croyance), morality (la morale), and rite (le culte). He

${ }^{91}$ Whether he recorded the vernacular titles these myths were given by the Miao is left untold.

${ }^{92}$ Le Roy Alexandre, La Religion des primitifs, Paris: Gabriel Beauchesne et Cie, 1909. This book has been produced from Le Roy's published lectures given in a namesake course in 1907-1908 when he was the first holder of the Chair on the History of Religions at the newly established Institut de Science et de Théologie des Religions in Paris. Bishop Le Roy missionised for nearly fifty years in central Africa among a number of 'primitive peoples.' It was from this experience that he wrote the book Savina was visibly fond of. 
argues that beliefs are the basis of religion, in turn morality refers to beliefs turned into practice, and rites are the manifestation or the expression of those beliefs. To locate aspects of Miao religion under each of these dimensions, Savina states that Miao beliefs are based, among other things, on monotheism, on the separation of body and soul, and on death as a consequence of sin, all ideas they conveniently share with Christians. Miao morality, a notion that Savina also cares to define using the less controversial, time-tested teaching of Thomas of Aquinas, simply reflects the "Laws of Nature" common to all "Men." What he perceives as an unambiguous overlapping between Miao and Catholic morality is of great strategic importance:

It would be a relatively easy task to graft Christian morality on Miao morality; all that is needed is to rectify a few errors $[\ldots]$ and to complete their beliefs in order to give the two moralities the same religion as a basis. ${ }^{93}$

He explains that to perform rites, the Miao have shamans, a category of ritual intercessors able to talk to the Supreme Being and obtain favours of all sorts. In Savina's mind, the fact that the shamans routinely perform rites to propitiate benevolent spirits or repulse malevolent ones, does not contradict the fundamentally monotheist nature of the Miao. Spirits are entities that must be dealt with, but they are not objects of worship. Only the Supreme Being is. That also explains, he assesses, why each household head is empowered to perform a number of rites to mediate between the spirits and his own kinship group, while only the shaman can connect with the Supreme Being.

Having demonstrated that the Miao indeed have a religion, Savina then wishes to discover its origin and assess its antiquity. He first explains the tenets of the comparative study of religions as proposed by Bishop Le Roy. A well-read cleric, Le Roy drew from Max Müller, Salomon Reinach and Cornelis Petrus Tiele, but according to Savina's daring critical appreciation of these authors, this new field of comparative study of religions was still lacking. Savina believed that this was rooted in these authors' lack of first-hand experience with the groups they used for their comparisons. He instead believed that a more inductive approach, with a clear focus on one specific religious tradition, was the only way out of this impasse. To him,

${ }_{93}$ Savina, Histoire des Miao, 251. 
one has to go among all these peoples, and preferably among the most ancient ones, the most primitive, the most backward ones, in one word, the most savage ones, live among them, get a deep knowledge of their languages, and carefully study their religious thinking. ${ }^{94}$

A study such as his own among the antique Miao, he contends in an intellectual pirouette that demotes deductive research to replace it with unwarranted induction, had allowed him to discover principles that could be generalised to all of Humankind. His generalisation goes as follows: once having received religion through divine intervention, primitive families absorbed it and passed it on. Families, becoming more numerous over time, grouped to form tribes, which in turn grouped to form nations, always transmitting religion via the family. Later again, religious elements took the shape of, or were influenced by, various mythologies and superstitions while magic inevitably penetrated and tainted the antique traditions based on the primitive religion (where did these superstitions and magic come from? Savina does not tell). Yet, the structure, the principles of primitive religion remained always and everywhere identical for peoples from all races and, he argues, is still visible today to the trained eye. Therefore, for Savina, studying antique Miao religion provides a direct line in the quest for the primitive religion, the universal source of all religious systems today. He is convinced that what he has found about antique Miao religion is a valid blueprint to help reveal structural elements of all religions on Earth. ${ }^{95}$ In the last paragraphs of Chapter 4, Savina writes emphatically:

I have tried to situate the Miao people among the other peoples on the world map, in linguistic, ethnographic, geographic, historical, and religious terms. I am well aware of the difficulty of such a task and of my personal flaws. I felt the need for collaborators whom I was not fortunate enough to find on my path. For this reason, I had to content myself with touching on certain questions which I would have liked to have studied more deeply. I am far from having exhausted the seam that I have unearthed, and the field remains open to new research, to more detailed investigations. But however far these investigations will be pushed, I am convinced in advance that there will be a broad agreement to declare that the Miao people are very old, perhaps the oldest of all currently in existence on this planet, and that their traditions, secular as

\footnotetext{
94 Ibid., 268.
}

95 Ibid., 279. 
well as religious, probably take the first rank among all other non-literate peoples who have reached us in this time.

Indeed, the Miao religious traditions go back, along with their cosmogony, to the very cradle of Humankind, and tell with an astonishing authenticity, along with the Bible's narrative, the great events that dominated the whole history of primitive society, from creation to the dispersion of peoples.

Their secular traditions, which start at this latter event, and whose last fifty centuries belong to history, are also the longest recorded in Humankind's annals to this day.

These two traditions, united, offer a historic interest which shall not escape anyone's attention, as it makes the Miao people, still unknown yesterday, the witness people par excellence, next to the Jews, of the first age of the World. ${ }^{96}$

For Savina, working on Histoire des Miao did not seem to constitute in any way a critical reflexive process, and probably not even a logical project. It was a plea, essentially a rhetorical exercise in convincing his readership that his conclusions, which he had reached before starting his study, were valid and, indeed, pertained to the Truth. As for the scientific process itself, he did not hold it in high enough esteem to let it divert him from his mission.

In a short Appendice to the book, devoted to the 'Future of the Miao race' and probably added just before publication, a more sober Savina warns that one should nurture no illusions as to what is in store for the smaller 'races' of the World, a fate he, born in Brittany, has experienced first-hand. In his own words:

It is evident that the secondary races, less numerous, and nomadic, such as the Lolo, Man, and Miao, will follow the dominant races, will be absorbed in those new States, they will lose what is left of their autonomy, and will cease to constitute relatively independent groups among other peoples as they are today. But for that matter, these races won't disappear, and it is probable that for many more centuries, the Miao will maintain their antique customs and speak the millennia-old language of their ancestors. They will later become in Asia what the Basques and the Bretons are in Europe today. ${ }^{97}$

Clearly, Savina's interest in Miao antiquity was not accidental. A priest sent on an apostolic mission, Savina could only have had an ideologically

96 Ibid., 283.

97 Ibid., 286. 
biased agenda when conducting his enquiries, as boldly appears in Histoire des Miao. With an evolutionist state of mind, and one that was heavily tainted with the ambient monogenist ideology of his days, Savina was on the lookout for definitive connections between remote upland peoples and the first inhabitants of this planet, whose rapport with the Creator was immediate. Pervasive biblical preconceptions and references acted insidiously to distort his consideration of the Miao, searching as he was for a lost tribe of Israel or even more antique peoples not mentioned in the Old Testament. As such, he searched for clues in the oral histories and the collective memory of the Miao. Using comparative linguistics in its simplest form, that is lexicological comparison, and banking on the Miao's long isolation from excessive outside influence, he probed their collective memory in the hope of unearthing the words inherited from first-hand witnesses of the great events recounted in the Bible. His expectation was that such words would reveal something fundamental about the original Humans, something long forgotten by all other peoples. Undoubtedly, Savina was embracing Le Roy's admonition, spelled out in the introductory article he contributed to the inaugural issue of Anthropos in 1906, "Le rôle scientifique des Missionnaires" [The scientific task of missionaries]. There, the Bishop pointed to religion and linguistics as the fields of ethnographic inquiry that missionaries are best prepared and better advised to focus on. Le Roy explicitly spelled out the credo:

Religions, all religions, are like the ruins of an immense building that sheltered primitive Humankind [humanité] and of which the foundations remain everywhere, hidden under the thick bush of African fetishism as much as under the elegant religious elaborations of India and China. Therefore, the missionary must not irrevocably condemn everything. Instead, like an archaeologist digging with patience and great care, he must untangle what is primitive and oral from what has been borrowed, added and disfigured over the successive generations lacking guidance and light. Having thus found a local trace of the primitive foundation, he will use it to sit the Religion he has the honour being the architect of. ${ }^{98}$

With the Miao of Tonkin, Savina was convinced he had found those foundations intact. This conviction goes a long way to explains why, of all the highland groups he had met and studied during his time in

${ }^{98}$ Le Roy, Alexandre, Bishop. "Le rôle scientifique des Missionnaires." Anthropos vol. I, pp. 3-10, 1906, 8-9. 
Asia, the Miao was the only one to which he devoted a monograph. Also, among all of Savina's publications, Histoire des Miao is the only one to have ever known a second publication - in 1930 - indicating a degree of success at the time for this "very curious work still avidly sought after." ${ }^{\prime 99}$

\section{On Savina's legacy}

What value, one is left to ponder, does Histoire des Miao hold for anthropology today? Certain scholars have judged virtually any form of contribution to professional anthropology by missionaries as irrevocably flawed. For such scholars, the heavily biased agenda of its author would alone suffice to discard Histoire des Miao as a fantasist and unreliable document stemming from an obsessed mind. Fellow Frenchman Guy Moréchand has been particularly harsh. A trained anthropologist specialising in Hmong shamanism and active in the field in the 1950 and 60 s, he said of Savina:

Unfortunately, this missionary, remarkably gifted for the languages of the country, has proved to be a poor observer and a ghastly ethnographer. Each of his ruminations reflects the worst prejudice of his time and one can sense that he has resolutely pushed outside his field of observation everything he considered dangerous or contemptible 'superstitions'. Moreover, with a very limited cultural baggage, he has ventured into distressing wild imaginings that would make an intelligent high school boy blush. His Histoire des Miao is a rather pathetic monument. ${ }^{100}$

Moréchand's severe judgment was a reflection of the prevalent anticlerical stance amongst French professional ethnologists in the late stage of France's colonial history, a time tainted by post-WWII trauma at home and violent independence wars in the African and Asian colonies. Moréchand did not seem prepared to accept the fact that Savina, quite obviously, was not a trained ethnologist but a simple missionary in the field with a penchant for linguistics and ethnography. This, Moréchand might have wanted to note, at a time when French professional

99 Comptes-rendus 1949: 182.

100 Moréchand, Guy. "Le chamanisme des Hmong." Bulletin de l'École française d'ExtrêmeOrient. vol. LIV, pp. 53-294, 1968, 56. Curiously, the full reference to Savina's Histoire des Miao in Moréchand's bibliography has a mistake in the title which he states as: 'Histoire des Miao-tseu'. Moréchand also inexplicably mis-referenced other publications by Savina and by Aloys Schotter. 
anthropologists were not (yet) often seen outside their offices. Giving due - even if carefully measured - credit to such an amateur ethnographer was not yet possible in the French ethnologist's psyche, with the innumerable and unforgivable mistakes of excessive missionary zeal imposed upon local cultures being still too fresh a memory.

Yet, for anyone who has knowledge of Savina as an ethnographer and who has carefully read Histoire, another dimension of the book immediately becomes prominent, a dimension that shows definite scholarly quality. When pruned of its most obvious blemishes, the monograph becomes a rich document depicting in detail aspects of the culture of a group about which, at that time, very little was known. This is a monograph written by a self taught ethnographer, prone to speculations typical of his state and time, but with undeniable talent. Colonel Henri Roux, under whom Savina served during the 1918-21 Laos episode and who later published his own book on minorities in Northern Indochina, was more lenient regarding Histoire's intellectual defects. He held the priest and his vast experience of the Miao in high esteem and observed that

there may be in that big book sections that can be seen as controversial, for instance an unexpected explanation of the Babel Tower and a statement on the kinship connection between the Miao and the Armorican Bretons; this put aside, that book is replete with precise and exact information on the Meo [Miao] whose language Father Savina knew admirably, to the point of fooling interlocutors talking to him without seeing him. ${ }^{101}$

As an ethnographer, especially a self-taught one, Savina did show unusual competence. Proof of his profound knowledge of the Miao emerges on every page of Histoire; it is also embedded in nearly every entry in his dictionaries. As an anonymous MEP colleague of his remarked, "in order to master the numerous languages of Tonkin, he did not hesitate to spend months and years among these peoples, living as they did, working the fields with the peasants, his notebook always at hand." 102

Thus, it is all the more intriguing that such a keen ethnographer, with a long experience of his subjects, missed particularly striking features of Miao religion such as the geomantic practices in house building,

${ }^{101}$ Roux, Henri (Colonel). "Quelques populations du Nord Indochinois." France-Asie, vol. 92-93, 1954, 413.

102 Comptes-Rendus 1949: 181. 
which he completely ignores. It is particularly strange that nowhere in Histoire does Savina make any significant comment on opium growing, an economic activity that was legal and widespread in the region at the time. Also overlooked are important elements of customary law in the kinship sphere, namely polygyny for wealthier men, and a (uneven) right to divorce for men and women under specific circumstances. Yet, in the Appendice closing the book, where he summarises the reasons why the Miao have survived five millennia as a distinct group, he explicitly states that one is that the Miao were monogamous, and that they ignored divorce. ${ }^{103}$ It is highly unlikely that he would have been unaware of polygyny and divorce as these were frequent practices among the Miao/Hmong; any newcomer in the field today learns about them very quickly. The most likely explanation for these omissions was censorship, either self-imposed or forced on Savina by the ecclesiastic apparatus in Hong Kong where the book was edited and published.

Savina's ethnographic work constituted a veritable thesis in the sense that he had a hypothesis in mind and set out to prove its validity. His intention had never been to construct an objective ethnographic record. Quite unknowingly, he followed the rule now largely accepted that ethnology should be more than the plain production of a catalogue of customs and practices. A substantial degree of analysis is also an inherent part of the discipline. But Savina did not successfully underpin his thesis. It is probably excusable that he did not know about early works of ethnologists such as Morgan, Tylor, Boas, or influential French philosophers and sociologists like Auguste Comte and Émile Durkheim. However, it is difficult to explain that in Histoire, Savina failed to mention or quote any anthropologists of his time for having contributed significant works on ethnography as a method and a science. Is it because Malinowski, Boas or Keller were published in English, and Graebner and von Luschan in German? Even if language was a problem in accessing literature, it is strange that Savina, writing in the early 1920s, did not make reference to Marcel Mauss in particular. Mauss' writings on ethnography in French, though not yet crystallized in his Instructions of 1935-1938, a premise to his landmark Manuel d'ethnographie of 1947, had been circulated as far as Indochina since the early years of the century. ${ }^{104}$ Also curious, and again perhaps reflecting

\footnotetext{
103 Savina, Histoire des Miao, 284.

104 Mauss, Marcel. Carnet Instruction pour les collaborateurs de l'École française d'Extrême-Orient.
} 
a discomfort with language, was the absence in Savina's discussion of the Miao, of references to the many works on that group by Protestant missionaries in southwest China, except for a very brief mention of relatively unimportant pieces by Edkins and Broumton. ${ }^{105}$ Here a large number of possible contributors were available, from Bridgman in 1859 to Hudspeth in 1922. Arguably, this disquiet was also generated by competition between Catholic and all other Christian missionary denominations. But the absence of Samuel Pollard's Story of the Miao published in 1919, just when Savina was working on Histoire, is particularly disconcerting given the clear relevance of that work to Savina's thesis. ${ }^{106}$

Even more conspicuous, if not outright disturbing, is the absence from Histoire of any mention of Father Aloys Schotter. As we have seen in Chapter 7, Schotter had recently published three substantial articles in Anthropos on the Miao in Sichuan in which he expressed ideas that could have contributed significantly to better founding Savina's research. ${ }^{107}$ Schotter's articles were published between 1909 and 1911, thus leaving enough time for Savina to get hold of them. In his book, Savina mentions explicitly the journal Anthropos thus confirming his acquaintance with it. It is very hard to believe that Savina did not know about Schotter. It is in fact practically unthinkable since, in addition to both being MEP members with their time in Asia overlapping for over two decades, they had a common pen friend, Paul Vial, whom, given his own interest in highland ethnography, surely must have told Savina

Saigon: Imprimerie Ménard et Legros, 1900; Mauss, Marcel. "Essai d'une instruction pour l'étude sociologique des sociétés indo-chinoises." In Premier Congrès International des Etudes sur l'Extrême-Orient, 1902, Hanoi: Schneider, pp. 92-3, 1903; Mauss, Marcel. Manuel d'ethnographie. Paris: Petite bibliothèque Payot, 1967 [1947]; cf. Mauss, Marcel. Euvres-3: Cohésion sociale et divisions de la sociologie. Paris: Editions de Minuit, 1969.

${ }^{105}$ Savina, Histoire des Miao, 164.

${ }^{106}$ Edkins, J. "The Miau-tsi, their history." China Recorder, vol. 2, 1871; Broumton. "A Visit to the Miao-Tsze. Tribes of South China." Proceedings of the Royal Geographic Society 3:225-226, 1881; Bridgman, E.C. "Sketches of the Miau-tsze." Fournal of the Royal Asiatic Society, North China Branch, vol. 3, pp. 257-86, 1859; Hudspeth, William H. "The Cult of the Door amongst the Miao." Folklore, vol. 33, pp. 406-10, 1922; Pollard, Samuel. The Story of the Miao. London: Henry Hooks, 1919.

107 Schotter, Aloys. "Notes ethnographiques sur les tribus du Kouy-tcheou (Chine): Introduction." Anthropos, vol. III, pp. 397-425, 1908; Schotter, Aloys. "Notes ethnographiques sur les tribus du Kouy-tcheou (Chine): II ${ }^{\text {ème }}$ partie: Les différentes tribus des Miao, chap. 1-4." Anthropos, vol. IV, pp. 418-453, 1909; Schotter, Aloys. "Notes ethnographiques sur les tribus du Kouy-tcheou (Chine): IIème partie: Les différentes tribus des Miao, chap. 5-9 et Récapitulation.” Anthropos, vol. VI, pp. 318-344, 1911. 
about Schotter. One is thus led to think that Savina had reasons of another nature to keep Schotter's work out of his pool of references. If it was because he disagreed with his colleague, he should still have said so. His silence here leaves him open to serious criticism.

In Nicholas Thomas' terms, Savina was a typical representative, though a late one, of the period when anthropology was a historical inquiry. "Comparative method for the study of institutions entailed developmental narrative and drew upon a range of classical, biblical, and ethnological sources. [...] By modern standards, its use of sources was opportunistic and uncritical." ${ }^{108}$ Diffusionist arguments like Savina's linguistic connections between the Miao and Middle Eastern Antiquity, tended to be speculative, producing results which could at least be called conjectural history.

Yet, to his credit, unlike most of his missionary colleagues whose writings focused primarily, or even exclusively on this or that tribe, Savina's Histoire des Miao is replete with references on different groups elsewhere in Asia. These accounts came from missionaries and scholars, either past or contemporary ones, as well as from a good number of colonial military officers, diplomats, and administrators. Their publications nourished his reflection and influenced his thinking. In fact, Savina's choice of references appears to reflect his persona at least as much as his intellectual bearings. He favoured colleagues in religion, authors from the colonial establishment and carefully selected Orientalists such as naturalist and physician Armand de Quatrefages de Bréau, the influential 19th century anatomist who supported monogenism and opposed the notion of the primate origins of Humankind. ${ }^{109}$ Conversely, Savina ignored just about anyone not supporting his case, and I am now inclined to think, probably anyone he disliked for one reason or another.

Had he wished to, he was in a position to discuss his observations with knowledgeable colleagues within his reach. For instance, at the time of his first stay in Vinh-tuy in the Ha-giang region, from 1906 to 1911, Savina certainly had the opportunity to discuss his impressions with a number of military officers who had been involved in the substantial

108 Thomas, Nicholas. "History and Anthropology." In Encyclopaedia of Social and Cultural Anthropology, eds. Barnard, A. and J. Spencer, London: Routledge, pp. 272-277, 1996, 272.

${ }^{109}$ Quatrefages de Bréau, J.-L. Armand de. L'espèce humaine. Paris, Librairie Germer Baillière, 1883. 
ethnographic survey of the northern Tonkin frontier conducted in 1898 and 1903 following orders from the top colonial administration. ${ }^{110}$ Many of these earlier agents were still around in 1906. Among them was another talented self-made ethnographer, Auguste Bonifacy who was then commander of a district and later Commander of the Third Military Territory which encompassed the upper Clear River basin. ${ }^{111}$ Annual MEP meetings in Hưng Hoá, Hanoi, Haiphong and years spent at the Hong Kong house were also clear opportunities for Savina to exchange viewpoints with fellow missionaries. A fair number of these contributions have been acknowledged in Histoire des Miao; a number have also been left unmentioned. It is not possible to assess with certainty which ones.

Surely aware of many of these weaker points in his research, Savina hastily attempted to silence his potential critics. A shrewd, self-taught man working alone, very capable of challenging the rules and aware of his immense capacities and resourcefulness, he turned his rural roots and lack of higher education into an advantage when it came to studying peasants. This conviction is palpable throughout Histoire des Miao. In a few pre-emptive sentences, he also shunned the pretence of posing as a professional anthropologist by reframing his intellectual contribution as one by a serious amateur, for "one can be curious without belonging

${ }^{110}$ It is this effort that yielded two significant publications: Lunet de Lajonquière, Emile (Commandant). Ethnographie des territoires militaires (Rédigé sur l'ordre du Général Coronat d'après les travaux de M.M. le Lieutenant-Colonel Diguet, le Commandant Révérony, le Capitaine Fesh et al.). Hanoi: F.H. Schneider, 1904; Lunet de Lajonquière, Emile (Commandant). Ethnographie du Tonkin septentrional (Rédigé sur l'ordre de M.P. Beau, Gouverneur Général de l'IndoChine française, d'après les études des administrateurs civils et militaires des provines septentrionales). Paris: Ernest Leroux, 1906.

111 The very small number of educated Frenchmen living in the Clear River basin at the time would routinely congregate during various occasions over any given year, and thus they had a chance to exchange views. I believe it is virtually impossible that Savina, during his posting in Vinh-tuy, would not have had several opportunities to meet the military officers in the Third and Forth Military Territories, in particular an officer such as Bonifacy who was heavily involved in the ethnography of the Man (Yao) and the Thô (Tày) and thus shared a common interest with the missionary. Had Savina not declared, as reported by Trivière ("Révérend père F.-M. Savina.") that while in Vinh-tuy, he had focused his attention - though not exclusively - on those same Man and Tay? If one adds to this contextual evidence the fact that Savina was likely to have been in close contact with the military organisation due to the services he was able to render them, not to mention the fact that Bonifacy spent the rest of his life in Tonkin (he died in Hanoi in 1931), it becomes difficult to doubt that Savina had developed a rapport, if it were only an antagonistic one, with Bonifacy and/or his close collaborators. 
to the family of great minds."112 He therefore explicitly acknowledges the methodological limitations of his work:

I lacked the means, that is to say the documentary resources. But even more importantly, I lacked collaborators. The problem I have raised exceeds the strength of a sole man and could only be solved by several competent persons in collaboration, collaborators knowing the languages of the said peoples and having visited their entire habitat. ${ }^{13}$

Even as a field worker, his undeniable strong point, Savina saw his limits. To compensate for his lack of personal experience, he used field data from regions he had never visited himself instead of leaving those populations out. Surprisingly, he also observed, with regards to a particular ritual of Miao funerals: "that same macabre ceremony exists among the Miao in Tonkin but I never witnessed it, for I never found the courage to attend one," 114 an unexpected scrupulousness for such a seasoned fieldworker. His ethnographic contribution was a work where women were largely absent, both as subjects and as a source of information. He cannot truly be blamed for the omission, the lack of such an insight being obviously related to his missionary condition and indeed, the era.

In addition to possibly being cold shouldered by some among his colleagues due to his personal failings that caused him to be repeatedly disciplined and, as a consequence, the somewhat preferential treatment he was given by his Bishop who relieved him from the chore of day to day proselytising and sent him travelling instead, Savina also had to face a lack of understanding of the value of his work by his peers. In all probability conveying the dominant opinion among his religious colleagues, the anonymous author of his official obituary saw fit to stress that it was strongly regretted that the deceased preferred devoting five years of his life to writing a scholarly multi-language dictionary, rather than provide his brothers in mission with practical lexicons in various minority languages and as many translations of the catechism. ${ }^{115}$

But at the end of the day, with all of Savina's flaws and biases, I nevertheless share the opinion of Léon Trivière when he writes that François Marie Savina's contribution to the ethnography of French

\footnotetext{
112 Savina, Histoire des Miao, x.

113 Ibid., 110.

114 Ibid., 230.

115 Comptes-rendus 1949: 182.
} 
Indochina was an important one which earned its author the right to sit at the same table as other better known missionary ethnographers of French Indochina such as François Callet and Léopold Cadière whose distinctive and distinguished contributions Georges Condominas has brought to public attention. ${ }^{116}$

116 Trivière, "Révérend père F.-M. Savina," 29; Condominas, Georges. "Deux grands ethnologues pratiquement inconnus de la profession: les pères François Callet et Léopold Cadière." In Histoire de l'Anthropologie XVI-XIX siècles, ed. Rupp-Eisenreich, B., Paris: Klinsksieck, 1984. 
GONCLUSIONS 
Jean Michaud - 978-90-47-42021-7

Downloaded from Brill.com๑4/26/2023 $\odot 9: 56: 23 \mathrm{AM}$

via free access 


\section{RIVALRY, AVOIDANCE, AND SGIENTIFIC LONGING}

In his analysis of the work of Recollect missionary Chrestien Le Clercq who was active in the French colony of Canada in the late 17th century, Serge Trudel reflected on the topic of ethnographic discourse:

Narration is subject to two main functions: that of the speaker organizing his narrative (management function, fonction de régie) and that of the participant (testifying or attestation function, fonction testimoniale ou d'attestation), either by testifying on what he has himself seen or heard on location where the event or the anecdote he recalls occurred (testifying function), or by attesting, as reader, the reality of the documents he used to authenticate the event or the anecdote he has reported (attestation function). ${ }^{1}$

Such understandings of ethnographic narration also applies to the missionary authors we have met in this book. There is little doubt that a more or less conscious form of participation was their dominant method of fieldwork. However, in organizing their narratives, writers from the Société des Missions Étrangères de Paris posted in highland Southeast Asia took quite different paths from each other. I propose to categorise these paths on the basis of the intention of the authors and the type of vehicle through which they elected to disseminate their prose.

The first category brings together writers with no particular ethnological intention. Encompassing the vast majority of missionary authors in the field, a typical representative of this category is Léon-Marie Girod, whom we followed in Chapter 6, who wrote on his voyages through Upper Tonkin in the late 19th century. We saw that Girod was a path breaker in the upper region and the accounts of his journeys on the frontier were met with great popularity back in France. While his prose reached his audience through regular quotes in the yearly Comptes-rendus from his vicariate, it was mainly through popular missionary journals such as Les Missions Catholiques that he expressed himself. A mobile author rarely stationed in the same location for very long, Girod's stories

1 Trudel, Serge. Étude de genèse: le cas de Premier établissement de la foi dans la Nouvelle France (1691). Ph.D. Dissertation, Etudes françaises, Université de Montréal, 1997. Online version located at http://www.pum.umontreal.ca/theses/pilote/trudel/these.html. 
took the shape of linear, uncritical narratives of his peregrinations. As such, they were above all light in content, lively, entertaining, and held comparatively little material of an ethnographic nature.

The second category bands together the writers who showed clear signs of harbouring at least some ethnological intentions, but who did not see fit to go much beyond what was actually useful to the better performance of their ministry. This group is significantly smaller than the previous one, this time encompassing missionaries who were in long and regular contact with local populations, who mastered the vernacular language(s), and for whom the best performance of their apostolic work depended on their knowledge of the prospective converts' culture(s). Typical representatives of this category are Antoine Bourlet in Laos, Aloys Schotter in Guizhou, and Paul Vial in Yunnan (see Chapter 7). All have openly stated in their publications that studying the 'natives' and their history, religion, and culture was an integral part of missionary work. This was one duty without which competent proselytising was not going to release all the fruit it had the potential to yield. Contrary to their more numerous colleagues in the first category, these authors had, deliberately or not, welcomed Father Wilhelm Schmidt's invitation to organise their observations in a structured way and make them available through publications to colleagues and other learned readers. In the cases of Bourlet, Vial, and Schotter, the outlets for their prose still included the Comptes-rendus and the usual popular missionary journals, but they strategically targeted more scholarly outlets such as Anthropos and the occasional book published by their mission's printing house.

To the third category belong writers with an open, explicit scientific intention underpinning their publication projects. Considerably much smaller that the two previous ones, this category is suitably represented in this book by two exceptional authors, Alfred Liétard in Yunnan and François Savina in Upper Tonkin, whose work we considered in Chapters 7 and 8 . Both gave not more than a passing thought to the utilitarian dimension of their texts, that is, the fact that they should be of practical value to their colleagues in Christ; indeed, Savina in particular showed a total disinterest in such an objective, which led his critics to voice their dissatisfaction. Instead, both men openly claimed a methodical, non-utilitarian ideal aimed at better understanding the highlanders they worked with. To a degree, both shunned the Comptesrendus and popular missionary journals and targeted instead publications aimed at scholarly audiences. The fact that Liétard's Au Yun-nan was published as a book by Anthropos Bibliothek constitutes in itself a level of 
scientific approval that none of his contemporaries ever achieved. ${ }^{2}$ For both men, scientific recompense and awards from the French scientific community also confirmed the value of their pursuits to the broader world. That their apostolic careers may have been jeopardized due to their intellectual focus going beyond the restrictive missionary horizon did not seem to bother them too much.

One could be tempted to argue that Paul Vial, with a solid ethnographic contribution such as Les Lolos, was also a candidate for the third category. ${ }^{3}$ But, it is a fact that beyond this particular and important piece, Vial harboured no open scientific intent, and certainly not one of a kind that could jeopardise his pastoral mission. Vial's perception of his own work remained that of a missionary in the field. His grammars, catechisms, and schoolbooks are there to remind us precisely of that. In addition, the rest of his prose was most regularly, and for the longest period, published in Annales de la Société des Missions-Étrangères and Les Missions Catholiques, both decidedly popular outlets. While I acknowledge that in some aspects Vial stands with one foot in both categories, I feel it is in the second that he fits more genuinely.

We can then appreciate that for each of these three categories, the authors' modes of writing also matched their intentions. For those belonging to the first category, the style is above all engaging. The whole of their production - think of Léon Girod's Souvenirs franco-tonkinois - is based on first-hand observations woven into an attractive, engaging narrative built around the readership's expectations of adventure, curios, and encounters with exotic peoples. In the second category, the style is functional. Here, authors focus on what is of practical use to themselves, to their colleagues, and to their converts, with language and education coming high on the agenda. Countless language dictionaries as well as Vial's textbooks, again, are a fine example of this style. For the third category, the style is studious. The texts are detached from the missionary society's needs and expectations; one could hardly find a practical religious use for them. Indeed, Savina and Liétard produced their scholarly pieces clearly besides performing their apostolic duty, or, in Savina's case, in its place. ${ }^{4}$

\footnotetext{
${ }^{2}$ Liétard, Alfred. Au Tun-nan: Les Lo-lo p'o. Une tribu des aborigènes de la Chine méridionale. Münster: Aschendorffsche Verlagsbuchhandlung, Anthropos Bibliothek, 280p. 1913a.

${ }^{3}$ Vial, Paul. Les Lolos. Histoire, religion, møurs, langue, écriture. Etudes Sino-Orientales, part A. Shanghai: Imprimerie de la mission catholique, 1898.

${ }^{4}$ Girod, Léon. Souvenirs franco-tonkinois 1879-1886. Paris: Desclée, de Brouwer \&
} 
Let us focus for a moment on the third category, the one which interests this book most. Our authors in the highlands examining the 'natives' and writing in a studious style are characterised by what I am inclined to call scientific longing. In the French colonial tradition as we saw in Chapter 3, predecessors such as Gabriel Sagard (c. 16001650), Joseph-François Lafitau (1681-1746) and Pierre de Charlevoix (1682-1761) were early messengers of Catholicism to the New World whose works - along with other dominant figures like Dominican Bartolomeo de Las Casas (1484-1566), Franciscan Bernardino de Sahagún (1500-1590), or French Protestant Jean de Léry (1534-1613) — became instrumental in conferring a degree of credibility to religious ethnographic accounts and to early anthropology. Not content with the mere descriptive listing of elements pertaining to material culture or with enticing depictions of the 'savages,' their appearance in France's first stretch of colonial expansion (16th c. to 1763) also meant that they belonged to an altogether different intellectual and missionary tradition. The early Jesuit ethnographers such as Lafitau and Charlevoix had aristocratic backgrounds and their education was well-rounded; in many ways, they were erudite and were strongly influenced by Jesuit ethics. ${ }^{5}$ Before its temporary dissolution in 1773 , the Society of Jesus was a hierarchical organization with advanced education, strict discipline, and broad knowledge of the natural and human world nurtured by an international missionary network. Due to their particular history and principles, the Jesuits became a customary home to sharp minds capable of standing next to powers-that-be wherever they missionized. 'Convert Princes first, the people will follow' was their motto. The Society arguably had become an important international scientific community of the early modern era.

What was left of this elitism in the education of regular religious recruits in France in the late 19th century could not compare. In most cases, including the MEP, the counterparts to the religious scholars of previous centuries were made of less distinguished fabric. They came into the picture at a time when France had started mining its coun-

Cie, 1900; for instance Vial, Paul. Calcul: les quatre règles expliquées aux enfants. Hongkong: Imprimerie de Nazareth, 29 p. 1913.

${ }_{5}^{5}$ Cf. Blackburn, Carole. Harvest of Souls. The Fesuit Missions and Colonialism in North America 1632-1650. Montréal and Kingston: McGill-Queen's University Press, 2000; $\mathrm{Li}$, Shenwen. Stratégies missionnaires des jésuites français en Nouvelle France et en Chine au XVII ${ }^{e}$ siècle. Paris: L'Harmattan, 2003. 
tryside to mass-produce, as it were, missionaries for its fast expanding colonial domain. Of course, a number among the humbler crowd did, in spite of less prestigious backgrounds and formation, yield a scholarly production of sorts for their followers to admire, a production most of the time limited to the field of language learning tools, which were the compulsory figures for the active missionary intellect. In the second half of the 19th century and a few decades into the 20th, keen recruits with a sharp brain wishing to engage in intellectual ventures had to look elsewhere to find models to emulate, or else search earlier in the history of Western missions.

Another important difference between the earlier colonial missionaries and their followers was the fantastic development of modern science that occurred in the intervening time. Products of the Enlightenment, rationalism and scientific doubt had permeated practically every corner of Western thinking. Exposed from the mid-18th century onwards to this new paradigm and its specific discourse, for the first time religious thinkers could use an innovative form of logic to question the rationale of their ministry and attempt to find scientific bases to their actions that would complement their moral foundation. This, however, was a demanding task in the face of a conservative institution, an innovation the Church was not that keen to see become popular amongst its recruits. For the religious establishment, this was a time when the performance of missionary work in the colonies was pressing, and forming competent recruits to that end was the dominant strategy. In the field, faith had to remain sheltered from the wanderings of Science as much as possible and for the 'natives' civilisation was to come first as a result of Christianisation. For the priests in turn, it was expected that moral fulfilment had to be achieved primarily through the competent and dedicated spreading of the divine Word to the pagans. Any other pursuit was futile, unnecessary, possibly costly, and certainly vain if not outright narcissistic. Publishing one's works for the entire world to see amounted to a selfish misuse of critically needed energy, far more appropriately used tilling and harvesting the fields of the Lord. ${ }^{6}$

${ }^{6}$ Compartmentalisation within missionary societies such as the Missions Étrangères de Paris meant also that exceptions could be made. The farther a missionary was from the apostolic field, the more academic endeavours would be judged leniently. Such was the case of prolific and celebrated MEP historian Adrien-Charles Launay (1853-1927) who had been sent back to France for health reasons after only five years in Cochinchina. He was then authorised to devote the rest of his life with the Society to archival work and historical studies, yielding over 40 books totalling in excess of 20,000 pages. 
In other words, intellectualism, ingenuousness, and initiative, which had been prerequisites, political duties, and a strategic necessity for Lafitau, Charlevoix, or Las Casas, had been spun into sins of egotism by the time Alfred Liétard, Paul Vial and François Savina had reached their missions. As a semi-reprehensible project, persisting in studiously penning research papers and getting them into print had turned, if I may say, into a mission. Who can blame these sharp but bridled minds, then, if they sometimes longed for the kind of recognition and appreciation their forefathers had received with their antique ethnographies of the 'savages'? They felt, it seems, an urge for their individual voices to be heard from a field they had expertly negotiated, sometimes with appreciable difficulty. How could they accept to remain humbly silent when, around them, opportunistic Europeans hurriedly roving 'their' mountains were publishing sketchy monographs bringing them fame? Paul Vial, for one, was far too polite to publicly voice what he thought of Archibald Colquhoun's two books following his short journey through Yunnan in the early 1880s, after, let us recall, Vial had assisted the great explorer and guided him back to safety in Burma. ${ }^{7}$ On the other hand, Alfred Liétard and François Savina did allow themselves to be a little less restrained in their critique of earlier authors on the Lolo and the Miao. But only just. I personally believe that their predicament mirrors that of today's anthropologists faced with the proliferation of touristy and journalistic exoticized accounts of the human groups they specialise on, that tend to become the truth for the masses of little informed readers. The choice is to remain silent and stubbornly carry on one's academic work, or somehow try to speak-up. 'Studious' MEP missionary ethnographers in Indochina perhaps spoke-up in their own particular way.

A small minority among the MEP authors were thus longing for a scientific label and probably for a share of scholarly fame. They most likely knew little of the potential risks of their hunt. Publishing their findings in the highly visible Anthropos, as opposed to the benign Les Missions Catholiques or the humdrum comptes-rendus, amounted to stretching their heads over the parapet and risking being examined by a broader audience in a much longer timeframe, as this book attests. It shouted out

Colquhoun, Archibald R. Across Chrysê. A Fourney of Exploration through the South China Border Lands from Canton to Mandalay. London: Sampson Low, Marston, Searle and Rivington, 2 volumes, 1883. 
to a secular readership their desire to be recognised for their competence in the field, but also for their scientism and intellectual rigour. They were not 'just' missionaries after all, they succeeded, in the middle of the daily hardships inherent to their remote tropical postings, in writing one, even several books and getting them published.

\section{Lagking Knowledge and Failing Memory}

Let us address the critical problem of sources, which seems to have affected our religious authors across the board. First, as far as the production of the texts goes, in all the Asian cases presented in this book references to earlier published French missionary ethnographers posted outside Asia are entirely absent. Second, all our MEP authors barely touched on sources, religious or otherwise, published in European languages other than French. What is particularly puzzling in the case of Upper Tonkin is that even texts produced by their Spanish Dominicans colleagues next door, installed for two centuries in the Protectorate of Tonkin, were ignored. Language discrepancy here can only be partially blamed since all could communicate in Latin and probably French. In Yunnan and Guizhou, Protestant and Anglican colleagues from the China Inland Mission were even more alien to the French priests, sharing the double indignity of speaking English and not being Catholic. Thirdly, French secular sources, be it from Tonkin or southwest China, get scarcely better treatment. A few are invoked occasionally such as Émile Rocher, while many among the most eminent ones are ignored. Auguste Pavie's Mission papers, Émile Lunet de Lajonquière, Edouard Diguet or Maurice Abadie's ethnographic anthologies are all overlooked. ${ }^{8}$

Reconnecting here with the case of New France we explored in Chapter 3, let us consider in more details the first group, that of earlier French Catholic authors from outside Asia. Remember Jean de Brébeuf (1593-1649)? As we have seen, Brébeuf was a Jesuit missionary to Huronia, who produced a seminal ethnographic text in 1635-36 on

\footnotetext{
${ }^{8}$ Pavie, Auguste et al. Mission Pavie. Géographie et voyages. Paris: Ernest Leroux, 7 volumes, 1898-1903; Abadie, Maurice. Les races du Haut Tonkin de Phong Tho à Lang-Son. Paris: Société d'éditions géographiques, maritimes et coloniales, 1924; Diguet, Emile (Capitaine). Les Montagnards du Tonkin. Paris: Librairie Maritime et Coloniale, Augustin Challamel, 1908; Lunet de Lajonquière, Emile (Commandant). Ethnographie des territoires militaires. Hanoi: F.H. Schneider, 1904.
} 
the Huron Amerindians. For him, studying the 'sauvages' was a survival skill. It was needed in order to eat and feel reasonably secure among these hosts, in addition to the pastoral necessity of finding an effective channel through which the Bible's message could be passed on. ${ }^{9}$ Brébeuf produced language tools to help his colleagues and wrote mainly for the benefit of his Society's Relations des Fésuites en Nouvelle France. He thus fits our category of functional writers discussed above.

Brébeuf's works are of interest to us here because they provided an early, easily available model for future missionaries to conduct ethnography. These works could have been explored by 19th recruits as a pragmatic measure to ensure the efficiency of the ministry and to ease hardships on assignment. In my opinion, had only one substantial body of missionary account from the French colonial past been available to future missionaries to muse over when preparing to perform their ministry, it should have been the massive, 41 volumes of the Relations des Jésuites en Nouvelle France of 1632-1673. These were perfectly coherent in style and purpose with the MEP comptes-rendus, their later counterpart. The formation years at the MEP seminary in Paris would have been a most appropriate moment to read and discuss them. It appears that such was not the case.

MEP clergymen interviewed in the course of researching this book could not explain such a regrettable absence. One can surmise that it may well have been dependent on two historical incidents. First, Relations was the product of the Society of Jesus, and the Jesuits were competitors to the MEP. The former's relative arrogance and spectacular fall from grace between 1773 and 1814, with their suppression worldwide by Pope Clement XIV (bar Orthodox countries such as Russia) was cause for their existence before 1773 to become somewhat obliterated from French memory. The second likely reason for this short psyche relates to the oblivion into which the New France adventure itself fell in French collective memory after the humiliation of the Seven Year War of 1756-1763. Never a star colony, not quite as exotic nor as attractive to the metropole as Martinique or Tahiti, and in the end a resounding diplomatic and military failure, the New France experiment, despite its 150 years lifespan, was probably better forgotten.

9 Thérien, Gilles. "Introduction." In Écrits en Huronie, Brébeuf, Jean de, Montréal: Bibliothèque québécoise, pp. i-lix, 1996. 
However, there is hardly a fitting combination of historical explanations to wholly justify the MEP tendency to shun such a valuable heritage from its forefathers. Historical interpretation must combine with a more down to earth set of explanations. The simplest of these, and probably the most plausible one, involves ignorance, considered here both as a state of mind and a strategy. I use ignorance to express the shortcomings of the uninformed mind, which is rather obvious, but also to highlight the strategy by ecclesiastic authorities to efficiently form hard working and not unnecessarily sophisticated cohorts of young missionaries for the colonies, at the lowest cost. Frailty of character, intellectualism, and the need for a European level of comfort had to be discouraged at the earliest stage of drafting; robustness in every possible aspect had to already be present or fostered to manufacture sturdy missionaries fit for a life of hardships. Hence the convenient recruitment of candidates from rural peasant life, which guaranteed both their physical preparedness, vigour, and their lack of interest in intellectualizing the world and their personal place within it. The message of God to the 'natives' was a simple one, His messengers had to be uncomplicated spokespersons leading an exemplary life.

Ideology was also at play. In late 19th century France, the MEP missionary ideal that was offered to recruits promoted the 'sacrificial lamb' model. Martyrs of the Faith, as explained in Chapter 4, were the most compelling examples for many among the young men. These models were actively promoted by the missionary institution with implements such as a 'martyr room.' In-house hagiographies of Théophane Vénard, Jean-Charles Cornay, Pierre Borie, Jean-Louis Bonnard, and Augustin Schoeffler, all celebrated 19th century MEP men killed in Tonkin, were readily available. Thus, getting to read Sahagún, Lafitau, or Charlevoix for their views on the 'savages' - presuming that some recruits may have wanted to do so - was not a straightforward task at all. In fact, reading just about anything outside the narrow focus of austere religious education was made even more difficult by religious censorship (l'Index) governing what could be accessed in the library.

It is difficult to deny that even by the turn of the 20th century, the MEP directors and educators in Paris were actively discouraging the extra-curricular learning process among their candidates to priesthood. The former showed little or no awareness of the ethnographic dimension of their pupils' future work in the field. Yet, one can argue that without having in any way to unnecessarily expose the recruits to 
unwanted theories on the origins of Humankind such as were being spread in evolutionist circles of the time, there were plenty of religious authors at hand who had said something useful on ethnography, either as a purposeful practice instrumental to the success of missions abroad, or as a potential glimpse back into the Biblical origins of Man. For instance, in 1887, MEP missionary Jean Guerlach (1858-1912), attached to the Eastern Cochinchina vicariate in the highlands of south Vietnam, wrote a few pages on his field methods in an article on the Bahnar minority published in the very correct Les Missions catholiques..$^{10}$ Later, in Anthropos, Bishop Le Roy (1854-1938), probably the first missionary author to explicitly call for his colleagues to "become anthropologists," released the article on the scientific role of missionaries mentioned in Chapter 8. He made the point that to successfully spread the Christian faith, a "battle plan" (his words) has to be established, which should comprise the study and understanding of the country and its inhabitants, including native mores, laws, religion, and languages. Made aware of the limitations of missionary formation and life by years of pastoral activity in Gabon, Le Roy also stated: "But the missionary too often lacks a scientific formation and a critical mind, he is not used to conducting research and intellectual work, he lacks time, money, organization, and the necessary encouragements." ${ }^{11}$ The message to clerical authorities here could not be clearer.

A few years later in 1912, taking up Le Roy's call, Léopold Cadière (1869-1955), attached to the MEP Hue vicariate in central Annam and a prolific author on the religion of the Annamites, contributed a paper on fieldwork methods to the first conference on Religious Ethnology held in Louvain, Belgium. ${ }^{12}$ With these Instructions pratiques pour

${ }^{10}$ Guerlach, Jean. "Moeurs et superstitions des Bahnars. Journal de voyage de M. Guerlach." Les Missions catholiques, vol. 19, pp. 441-527, 1887.

${ }^{11}$ Le Roy, Alexandre. "Le rôle scientifique des Missionnaires." Anthropos vol. I, pp. 3-10, 1906, 10. See the analytical presentation of this article by Laburthe-Tolra, Philippe. "L'ethnologue Alexandre Le Roy (1854-1938)." Mémoire spiritaine, vol. 12, Second semester, pp. 62-71, 2000.

${ }^{12}$ Cadière, Léopold. "La Semaine d'Ethnologie religieuse tenue à Louvain." Les Missions Catholiques, 493-495, 1912. Between 1912 and 1932 five such Semaines d'ethnologie religieuses conferences were held, initiated by clerics such as Wilhelm Schmidt, at which were discussed matters pertaining to missiology and missionary ethnology. See Courtois, Luc. "La première semaine d'ethnologie religieuse à Louvain en 1912. Les débuts difficiles d'une démarche progressiste sur fond de crise moderniste." In Servais, Olivier and Spijker, Gérard van 't (eds). Anthropologie et missiologie: XIX $-X X^{e}$ siècles: entre connivence et rivalité. Paris: Karthala, collection Mémoire d’Églises, 95-118, 2004. 
les missionnaires qui font des observations religieuses [Practical instructions for missionaries conducting religious observations], Cadière wished to give a functional shape to the encounter with the 'natives.' To do that, he claimed, it was more crucial to master languages in situ over long stays, than to merely bank on professional techniques, like the emerging caste of academic anthropologists. ${ }^{13}$ Cadière's instructions, immediately published in the in-house journal Annales de la Société des $M E P$, seem to have failed to reach his colleagues surveyed in this book who were still active then (Savina and Vial); or at least, none quoted him. A few years later again, Denis Doutreligne, missionary in Guizhou and a contemporary of Savina, clearly illustrated how the nascent field of missionary ethnology was gradually becoming an acceptable theme within the MEP. Doutreligne reported, in a short article included in the 1924 issue of Bulletin de la Société des Missions-Étrangères de Paris, on two recent meetings in which religious ethnology and religious science were discussed by clerics and secular scholars alike. One meeting was held in Tilburg, the Netherlands (the third Semaine d'ethnologie religieuse), the other in Paris. ${ }^{14}$ A sign of the changing times and of the increasing complexity of the social sciences, reference was explicitly made in those meetings to the Canadian experience, to Lafitau, and to more vocally anti-clerical authors such as Voltaire and Rousseau as well as social thinkers Auguste Comte and Émile Durkheim. Doutreligne diligently reported on all these sources. Expectedly, however, he brushed off the unpleasant scientific arguments and prophesized instead that the Catholic doctrine shall prevail to single-handedly explain the origin of Humankind and intelligence in the Universe - not unlike the 'intelligent design' doctrine one might say. Doutreligne concluded on the vital role of missionaries in the field as providers of competent ethnography requiring in turn an "exact and rigorous preparation in the observation of facts." Interestingly for us, the cleric also mentioned that an oral report on those meetings was presented to MEP recruits in

${ }^{13}$ Cadière, Léopold. "Instructions pratiques pour les missionnaires qui font des observations religieuses." Annales de la Société des Missions Étrangères de Paris, nos. 92-93-94, 1913. Cf. Lange, Claude. "Croyances et pratiques religieuses des Vietnamiens. L'œuvre du père Léopold Cadière (1869-1955)." In Anthropologie et missiologie: XIX $-X X^{e}$ siècles: entre connivence et rivalité, eds. Servais, Olivier \& Gérard van 't Spijker, Paris: Karthala, collection Mémoire d'Églises, pp. 211-228, 2004.

${ }^{14}$ Doutreligne, Denis. "L'ethnologie et les missionnaires. A propos de deux réunions: Tilburg (1922), Paris (1923)." Bulletin de la Société des Missions-Étrangères de Paris no. 33, septembre, pp. 549-554, 1924. 
Paris, who thus learned from both verbal and written sources about the current debates in the field of missionary ethnology. From then on at last, the excuse of ignorance was not available anymore to future MEP ethnographers - assuming that an availability of information was a sufficient condition to trigger insights and changes in deep-seated behavioural patterns; this in all probability remains to be established.

Scientific thinking took time to pierce the walls of the MEP, and in all fairness, of most other European missionary societies too. In France, non-Catholic, lay authors were long kept at the gates of seminaries and out of sight in religious libraries, underlining the fact that the relationship between Science and Faith remained an uneasy one for a very long time. Defiance, even a mild form of arrogance, played a key role in keeping religious ethnographers in the exclusive intellectual company of each other.

\section{Missed opportunities and the Republican obstacle}

Beyond possible sources of scholarly inspiration within the MEP or the broader Catholic sphere, even within the Christian faith at large, be it from the same time or earlier in history, it looks very much like a combination of avoidance and ignorance - in the sense of actively refusing to acknowledge - prevailed regarding sources from authors located outside the religious apparatus.

A paradox of late 19th century French ethnographic practice is that the first three editions of the British Notes and Queries on Anthropology, published in 1874 and re-edited in 1892 and 1899 have, to my knowledge, never been translated and published in French. James Urry has shown how important Notes and Queries have been to the development of British and American field research methods in anthropology in spite of flaws and errors that made them irrevocably outdated after the last edition in $1951 .{ }^{15}$ It is thus surprising that French ethnographers

${ }^{15}$ First edition: British Association for the Advancement of Science (ed.). Notes and Queries on Anthropology for the use of Travellers and Residents in Uncivilized Lands. London: Edward Stanford, 1874. And the last one: The Royal Anthropological Institute of Great Britain and Ireland. Notes and Queries on Anthropology, 6th edition. London: Routledge and Keegan Paul, 1951. Urry, James. "Notes and Queries on Anthropology and the Development of Field Methods in British Anthropology, 1870-1920." Proceedings of the Royal Anthropological Institute. [Reprinted in: Urry, J. Before Social Anthropology: Essays on the History of British Anthropology. Chur, Switzerland; Philadelphia: Harwood Academic Publishers, pp. 45-57 1993], 1972; Urry, James. "A History of Field Methods." In 
of all allegiances should have consistently passed up on the chance to use this handy toolkit to assist them in their own inquiries or simply to reflect on field methods. Beyond the language barrier, could ideological obstruction have been at play in this missed opportunity? ${ }^{16}$

Moreover, we know since the rediscovery of the original manuscript in the 1950s, that clear and practical instructions on how ethnographic inquiry should be conducted were written in French as early as 1799. A short-lived Société des observateurs de l'homme, the Society for the Observation of Man, had been set up that year, only to be abolished by Emperor Napoléon in 1804. Most notably, a conceptualisation and practical definition of participant-observation - though not called this - was proposed by Baron Joseph-Marie De Gérando in a series of detailed instructions to explorers setting out to study 'peuples sauvages. ${ }^{17}$ But this text remained confidential and practically unused for 150 years by French ethnographers.

Presumably, elements of methodological inspiration were tapped by our MEP missionaries in more general references. We saw in the previous chapter that Alfred Liétard in Yunnan quoted the work of Alexandre Chavannes, and François Savina referred explicitly to Armand de Quatrefages de Bréau. ${ }^{18}$ Chavannes' book series was not methodological in nature but Quatrefages, writing a century later, added to his writings general anthropological instructions for travellers,

Ethnographic Research: a Guide to General Conduct. ASA Research Methods in Social Anthropology, ed. Ellen, R.F., London: Academic Press, pp. 35-61, 1984.

${ }_{16}$ And I suspect that useful early works may have also been published by most of the other European colonial powers too, notably in Spanish, Portuguese, German, Dutch, Italian, Russian, and perhaps Swedish and Danish. My lack of familiarity with these languages prevented me from exploring these possibilities.

${ }_{17}$ De Gérando, Joseph-Marie. Considérations sur les diverses méthodes à suivre dans l'observation des peuples sauvages. [Considerations on the diverse methods to observe savage peoples] Paris: Société des observateurs de l'homme, an VIII, 1799, reprinted integrally in Copans, Jean \& Jean Jamin. Aux origines de l'anthropologie française: Les mémoires de la Société des observateurs de l'Homme en l'an VIII. Paris: Les cahiers Gradhiva, no. 23, Jean-Michel Place, 1993 [1978]. See also the seminal analysis of De Gérando's text in Stocking, G.W. "French Anthropology in 1800." Isis, LV(2), no 180, pp. 134-50, 1964; and Moore, F.T.C. (ed.). The Observation of Savage People by F.-M. de Gérando. Preface by E.E. Evans-Pritchard, Berkeley: University of California Press, 1969.

18 Chavannes, Alexandre César, Anthropologie ou science générale de l'homme, pour servir d'introduction à l'étude de la philosophie et des langues et de guide dans le plan d'éducation intellectuelle. 13 volumes, Lausanne, 1788; Quatrefages de Bréau, J.-L. Armand de. "Anthropologie." In Société de Géographie. Instructions générales aux voyageurs, Paris: Delagrave, pp. 244-58, 1875. 
above all on anthropo-biometry. But here again, referring to such sources was exceptional.

Now, with the information available on which to pass judgement, we have little choice but to conclude that outside of religious circles, no sources on fieldwork methods were notably explored and used by MEP missionaries working in upland Mainland Southeast Asia. It is in large part this kind of paucity, this incapacity among ethnographers of the 19th and early 20th century in the French colonies - not just clerics in upland Indochina - to fetch and use the tools available at the time to produce sound ethnography, that infuriated sociologist Marcel Mauss long before he set out to publish the first modern French fieldwork method manual in 1947, Manuel d'Ethnographie. Thirty-four years earlier, in 1913, Mauss wrote:

Historians, faced with the shortcomings of France's description of peoples, will declare: 'France behaved towards her subjects like nations of the Antiquity towards the Barbarians. She proceeded with contempt and used methods from another age. It is the French Republic's fault if we know no more about the New-Caledonians than the Romans taught us about the Ligurians. ${ }^{19}$

Even at that early stage in his career, Mauss was no stranger to the organisation of ethnographic research in upland Indochina. In the year 1900, aged 28, he had been consulted on how to organise field research in the highlands and contributed to preparing ethnographic enquiry tools. ${ }^{20}$ Questionnaires were put together with his aid in preparation for the major 1903 ethnological field surveys commissioned by the colonial authorities to the commanders of the Military Territories; these yielded a wealth of internal reports consistently structured along the same principles. These reports eventually led to major publications. ${ }^{21}$

${ }^{19}$ Mauss, Marcel. "L'ethnographie en France et à l'étranger." La Revue de Paris, vol. 20, pp. 537-60, 815-37, 1913, 837.

${ }_{20}$ Mauss, Marcel. Carnet Instruction pour les collaborateurs de l'École française d'Extrême-Orient. Saigon: Imprimerie Ménard et Legros, 1900. Mauss, Marcel and Auguste Bonifacy. Questionnaire de l'École française d'Extrême-Orient. Hanoi: Imprimerie d'Extrême-Orient, 1903. Regrettably, I could not lay eyes on either of these documents, which are not part of the 3 volume publication of the Mauss papers (Mauss, Marcel. EEvores. 3 volumes. Paris: Editions de Minuit, 1969), nor do they seem to have left any trace in the EFEO archives or at the Service Historique de la Défense, the French military archives in Vincennes. Reference to them, to their shadow as it were, exists in a few contemporaneous colonial documents.

${ }^{21}$ A number of these unpublished reports are kept at the EFEO archives in Paris, others can be found at the Centre des Archives d'Outre-Mer in Aix-en-Provence. Publica- 
Ad hoc production of ethnographic questionnaires was not rare in the French tradition; these tools were designed by professionals to assist non-professionals in the field in 'asking the right questions.' As noted by Pels and Salemink, ethnographic questionnaires remained common in France until well after World War II. ${ }^{22}$ Surely, these questionnaires, either in their original forms or picked from published documents, could easily have been borrowed by missionary ethnographers in the region? It seems they were not.

In sum, a variety of methodological tools were unquestionably available to missionaries and to other ethnographers in the region at the time. Some stemmed from initiatives sufficiently distant in time and in physical as well as intellectual space to explain why they were not adequately known or used in field research. Some tools, however, stemmed from sources much closer to home. Such oversight was extensive and can be less comfortably forgiven. Indeed, missionary ethnological reflection at the time, in spite of Le Roy's 1906 suggestion that Catholic missionaries should embrace ethnology, fundamentally stuck to what I am tempted to call a form of bricolage. Some of the bricoleurs were definitely talented and fully deserve scholarly attention today; I hope I have made the case for a few of them here. The vast majority, however, sticking to the religious organisations' call, simply aimed at pleasing an audience of lay readers without taxing the latter's intellectual resources beyond what was required to make them reach for their pocket. ${ }^{23}$

Finally, beyond the practicalities of individual choices, the lack of adequate preparation and the unavailability of written sources, we must also take into account macro-political developments in the late 19th century that played a role in curtailing missionary initiative on the ethnological front. Circumstantial political conditions erected walls separating segments of French society, in our case powers-that-be and academics on one side, and clerics on the other. This major influence

tions stemming from the 1903 surveys include Lunet de Lajonquière, Emile (Commandant). Ethnographie du Tonkin septentrional. Paris: Ernest Leroux, 1906; and Diguet, Emile (Capitaine). Les Montagnards du Tonkin. Paris: Librairie Maritime et Coloniale, Augustin Challamel, 1908. This ethnological survey was originally meant to cover the whole of French Indochina, but few results ever materialized outside of the northern Military Territories.

${ }^{22}$ Pels, Peter and Oscar Salemink. "Introduction: Five Theses on Ethnography as Colonial Practice." History and Anthropology, vol. 8, nos. 1-4, pp. 1-34, 1994, 10.

${ }^{23}$ Such cynism was not shared by everyone of course. See Spindler, Marc, "L'argent des missions et l'argent des chrétiens', Ad veritatem [Faculté universitaire de théologie protestante de Bruxelles], no. 27. Septembre, pp. 2-12, 1990. 
related to the Third Republic and its anti-clerical - its defenders would say secular -ideals.

In her book, A Mission to Civilize: The Republican Idea of Empire in France and West Africa, 1895-1930, a timeline matching ours, Aline Conklin demonstrates that under the Third Republic, which spanned from 1870 to 1939, France developed a colonial programme determined by the pursuit of economic profit - la mise en valeur - and by a political agenda of dominance that materialized in a self-ascribed mission to civilize - la mission civilisatrice. Incidentally, in the case of Indochina, this agenda was suitably illustrated in the titles of two publications from the 1920s by Albert Sarraut, Governor General of the Indochinese Union in the 1910s: La mise en valeur des colonies françaises, and La mission civilisatrice de la France. ${ }^{24}$

The Third Republic was born from the hot ashes of France's 1870 defeat to Prussia at a time when a nation mourned the loss of important segments of its territory to the victors. For the national political elite, collective humiliation was the dominant sentiment. The new breed of post-war leaders thus insisted on reinstating and spreading Republican ideals inherited from the Revolution with renewed vigour. Profitable overseas expansion became a golden opportunity to restore national pride, among other things. In Conklin's words, political leaders of the early Third Republic knew that "the ideology of the civilizing mission could not but strike a responsive chord in a nation now publicly committed to institutionalizing the universal principles of 1789." By 1895, this mission had become the official ideology of France's imperial expansionism..$^{25}$

Conklin also shows that a fracture occurred between the first colonial push of France, which ended at the conclusion of the Seven Year War in 1763, and the second colonial push starting with the North African adventure in the early 19th century. She demonstrates that the fundamental ideological shift that made the second phase distinct from the first was a consequence of the introduction of the modern notion of

${ }^{24}$ Conklin, Alice L. A mission to Civilize. The Republican Idea of Empire in France and West Africa, 1895-1930. Stanford: Stanford U. Press, 1997. Sarraut, Albert. "La mission civilisatrice de la France." Panorama no. 132, 1925; La mise en valeur des colonies françaises. Paris: Payot, 1923.

${ }^{25}$ Conklin, Alice L. A mission to Civilize, 2. See also Girardet, Raoul. L'idée coloniale en France de 1871 à 1962. Paris: Hachette, 2005; Mayeur, Jean-Marie and Madeleine Rebérioux. The Third Republic from its Origins to the Great War, 1871-1914. Cambridge: Cambridge University Press, 1984. 
civilization. In the first phase, commercial partners were sought in far away territories, and the fact that these partners remained 'barbarians' was of little concern, as long as business went on. Christianizing some among those partners merely meant, for France, lubricating the cogs of the trading machine. However, in the second phase, thanks in large part to the combined ideological effects of the Enlightenment and the Revolution, the exotic 'Other' had been promoted to the rank of a potential 'Us', a 'less-civilized' on a universal scale comprising all of humanity, in need of France's cultural lights to progress towards the more palatable state of 'near-civilized'-full equity was not quite yet deemed achievable. The expanding industrial agenda, based on increasing production and the constant need for new markets, became the motive for vigorous mise en valeur, conveniently posing in colonialist rhetoric as a positive outcome of colonisation for the 'natives.'

Nowhere in her book, though, does Conklin address the issue of Catholic missions and their political role in this expansion. Whether deliberate or fortuitous, this omission can be appraised in historical terms. Over most of the 19th century, the Republican ideals and scientific discourse on human progress inherited from the 18th century were challenged by numerous short lived and highly antagonistic regimes: the First Empire and Napoleon's hegemonic wars (1804-1814), restoration of monarchy (1814-1830), popular uprisings and military clampdowns (1830-1852), and, leading to the Commune uprising in Paris and the defeat to Prussia, the Second Empire of Napoléon III (1852-1870). Overall, a series of elitist, bourgeois or aristocratic governments were periodically challenged by the people. The quick succession of these regimes made French politics altogether volatile and hardly predictable. In the process, between 1799 and 1870, the battered body of the Catholic Church, which had enjoyed enormous privileges under the monarchy but narrowly survived the trauma of the Revolution, found itself invigorated by the restoration of its privileges under imperial and neo-monarchist governments. When came the Third Republic however, political leaders, many of them Free Masons, firmly intended to curtail this new strength. The Third Republic, most importantly, wanted to be secular and the landmark law of 1905 separating the Church and the State (Loi relative à la séparation des Eglises et de l'Etat) came to crystallise this agenda.

For the Missions Étrangères de Paris, this new political climate made recruitment more difficult at home, the image of the Catholic Church being demoted publicly by the secular authorities. It also made the 
running of missionary affairs in the colonies a much more complicated task with relationships with the state being less fluid than before. For all their astuteness, Bishop Puginier and his successors, as seen in Chapter 6, had to push hard to be heard in gubernatorial circles. In the field, individual missionaries were less and less capable of performing their work without the increased level of administrative support it required. More isolated in their individual missions than ever before, with dwindling numbers of new recruits from France to help and succeed them, but also with a growing threat of being drafted by the military to play the role of chaplain for the troops when the clampdown on nationalist forces began to expand, proselytizing was made difficult. The performance of any task not pertaining to core religious duties was becoming gradually impossible. Devoting time to observing the local hosts, to reading scholarly authors, or writing sound ethnography was not anymore an option for the vast majority of clerics stationed in outposts. This goes a long way to explain not only the decline in missionary activity in the northern uplands after the 1920s, but also the gradual disappearance of missionary ethnographic publications from highland Tonkin and Yunnan after Paul Vial and, a few years later, François Savina left the scene.

\section{FinALE}

Over four hundred years, from the 16th century with the first state commissions for clerics to board exploration, military, and merchant ships sailing to the new worlds, to the mid 20th century when independence wars sent European colonists packing, a degree of continuity in the methods, style, presuppositions, intentions, and even intuitions is recognizable from the time of the early generations of missionary observers and writers, to their heirs in the heyday of 19th century French colonialism. For the missionaries of the Société des Missions Étrangères de Paris presented in this book, this continuity, in all likeliness, appears to have been both contextual - as demonstrated throughout this text - and fortuitous. It was fortuitous in the sense that, based on a lack of evidence to substantiate a possible claim that any heritage from their forefathers was effectively communicated to younger generations through seminary curriculum, it was not the result of a consciously produced and pursued strategy. Unconsciously, however, with the stability and the conservative values defining the missionary institution, a type of missionary habitus 
had formed in context and was efficiently passed on to new recruits through religious education and the emulation of deserving elders. Based on the examination of the works of MEP missionaries posted in the Mainland Southeast Asian Massif detailed in this study, we can state that this stability was ensured by a lacking or a defective capacity to cumulate knowledge and learn from predecessors and contemporaries, religious as well as secular. Instead, a form of intellectual inbreeding was prevalent, comforted in the assurance that there could be nothing like a Catholic missionary in the field, living for most of his life among 'his natives,' to become the best possible person to study, understand, represent, and publicly discuss their language, history, religion, and culture. The black robed bearded men in colonial hats may have been inclined by vow towards modesty, but they were not totally immune to the sin of pride.

Their attitude towards their protégés revealed a political sensibility too. While it is undeniable that these Christian messengers worked from inside and in harmony with the colonial system, it is equally true that many followed in the footsteps of Bartolomeo de Las Casas in denouncing the exploitation of the 'natives' by that same system. Paul Rabinow remarked, on their practice of ethnography, that:

[Missionaries] saw that ethnographic understanding was [not only] a linch pin for their own mission [but also one] for the survival of native culture in a healthy form. The task of the missionary-ethnographer was to gain an understanding of local custom that would enable him to change it without 'violating' its life sustaining form. ${ }^{26}$

Indeed, in this book, we have encountered open condemnation from a number of missionaries of the exploitation of the 'natives.' As thinking individuals, missionaries were agents, they could not be reduced to being uncritical, passive instruments of an arrangement bent on civilizing and generating profit for the colonists, its elite, and the metropole. Holding a definite share of power as actors, even if moving within an otherwise guarded configuration (the Church and the colonial state of course, but also on a personal level, their rural origins, their restricted education, their condition as single men, and so on), they could also envisage the situation from their particular viewpoints and pursue

${ }^{26}$ Rabinow, Paul. "Facts are a Word of God." In Observers Observed, ed. Stocking, George, Madison: University of Wisconsin Press, "History of Anthropology" series vol. 1, pp. 196-207, 1983, 201. 
another agenda. Hence the need I have emphasised in this book to analyse each missionary's written production against the particular background of their own life experiences.

Given its ideological foundation and tangible framework, the pastoral venture turned potential individual agency into practice. Agents like Savina used all the levers accessible to him in order to remain part of his missionary society while taking a distance from apostolic work and, in its place, engaging in scholarly pursuits more in tune with his personal desires and his beliefs on the role he could and should play regarding the highlanders. Others, like Vial, used his 'objective' position to set up, within the borders of his mission, a model society reproducing Western societal ideals and educating the 'natives'. He wished to provide them with the economic skills needed to survive those fast times and to resist assimilation. Alfred Liétard and Aloys Schotter both explicitly stated that their actions among their converts were at least in part directed at supporting the latter's efforts to maintain their cultures in the face of Chinese economic, political, and cultural hegemony. Like many amongst the best of missionary ethnographers, they were driven, in van Beek's words, by a "profound empathy for 'their population'."27

For each of these men, their true 'mission' had roots that went beyond the missionary ideology they adhered to. It was the product of a combination of opportunities including family background, early childhood experience, and social habitus. One could assess that these men, because of who they were as total personae, not just because of who they had turned into as priests and colonists, were subversive. They used what was left of their liberty to try to counteract excessive exploitation, support the underdog, and delay assimilation as much as possible. Being priests, that is, advocates of peace, not many tools were left to them to accomplish this. Observing, learning, understanding, and crucially, publishing became the means for some of them. Going public with their observations and opinions, sometimes against the wishes of their bishops and colleagues, was their personal form of sedition. Their efforts, as futile as they might appear a century later, were not misplaced. Missionary ethnography is being revisited, not just by modern clerics and scholars, but also by the heirs of the subjects themselves. Highland

\footnotetext{
${ }^{27}$ van Beek, Walter E.A. "Anthropologie et missiologie ou la séparation graduelle des partenaires." In Servais, Olivier and Spijker, Gérard van 't (eds). Anthropologie et missiologie: XIX $-X X^{e}$ siècles: entre connivence et rivalité. Paris: Karthala, collection Mémoire d'Églises, 25-44, 2004.
} 
ethnic groups forced to navigate the treacherous waters of globalization, ever more exposed to the siren song of the liberal market economy with its glittering promises, find in these early monographs a dog-eared portrait of themselves which, if not always true, remains decipherable and genuine. As Margaret Swain very sensibly wrote in the conclusion of her analysis of the work and legacy of Paul Vial in Yunnan: in the face of great adversity, "missionary Orientalism in Southwest China was a factor in ethnogenesis among peripheral groups". ${ }^{28}$

As 'incidental' ethnographers, missionaries in the mountains of Mainland Southeast Asia were remarkably qualified with vernacular languages and local experience. They were in a unique position to produce distinctive and exceptional observation pieces. After the incessant disorder of wars and revolutions that shook the region for so long, their texts today have become unique and priceless glimpses into the earlier embodiments of numerous minority cultures that have themselves substantially changed since, or, for many, have lost the memory of their past.

${ }_{28}$ The same could be said of Laos and Vietnam. Swain, Margaret Byrne. "Père Vial and the Gni-p'a. Orientalist Scholarship and the Christian Project." In Cultural Encounters on China's Ethnic Frontiers, ed. Harrell, Stevan, Seattle and London: University of Washington Press, pp. 140-85, 1995, 172. 
Jean Michaud - 978-90-47-42021-7

Downloaded from Brill.com๑4/26/2023 $\odot 9: 56: 23 \mathrm{AM}$

via free access 


\section{BIBLIOGRAPHY}

(Anonymous). "Mission du Haut-Tonkin. Aperçu historique." Bulletin de la Société des Missions-Etrangères de Paris. pp. 548-552, 1922.

Abadie, Maurice. Les races du Haut Tonkin de Phong Tho à Lang-Son. Paris: Société d'éditions géographiques, maritimes et coloniales, 1924.

Abbink, Jan. "Anthropology and the Missions: A Critical Epistemological Perspective." Methodology and Science, vol. 18, pp. 254-70, 1985.

- . "Anthropologists, Missionaries and Rationality." In The Ambiguity of Rapprochement. Reflections of Anthropologists on their Controversial Relationship with Missionaries, eds. Bonsen, R., H. Marks and J. Miedema, Nijmegen: Focaal, pp. 121-50, 1990.

Asad, Talal. "Afterword: From the History of Colonial Anthropology to the Anthropology of Western Hegemony." In Colonial Situations. Essays on the conceptualisation of ethnographic knowledge, ed. George W. Stocking Jr., Madison: University of Wisconsin Press, History of Anthropology series, vol. 7, pp. 314-24, 1991.

_ . "Introduction." In Anthropology and the Colonial Encounter, ed. Asad, Talal, London: Ithaca Press, Atlantic Highlands (NJ): Humanities Press, pp. 9-19, 1973.

- (ed.). Anthropology and the Colonial Encounter. London: Ithaca Press, Atlantic Highlands: Humanities Press, 1973.

Balandier, Georges. "The Colonial Situation: A Theoretical Approach." In The Sociology of Black Africa: Social Dynamics on Central Africa. New York: Praeger, pp. 34-61, 1951 (1970).

Blackburn, Carole. Harvest of Souls. The Fesuit Missions and Colonialism in North America 1632-1650. Montréal and Kingston: McGill-Queen's University Press, 2000.

Bon, Henri and J.B. Dronet. Manuel de conversation franco-tonkinois. Késo: Imprimerie de la Mission, 1889.

Bonifacy, Auguste Louis-M. Ethnographie de l'Indochine. Vietnam, Cambodge, Laos. HanoiHaiphong: Imprimerie d'Extrême-Orient (Gournement Général de l'Indochine), 1919.

_. "Monographie des Man Quan-coc." Revue Indo-Chinoise, (30 novembre): 726-34; (15 décembre), pp. 824-32, 1904.

—. "Contes populaires des Mans du Tonkin." BEFEO, vol. II, pp. 268-79, 1902.

Bonsen, Roland, Hans Marks, Jelle Miedema (eds). The Ambiguity of Rapprochement. Reflections of Anthropologists on their Relationship with Missionaries. Nijmegen: Focaal, 1990.

Bougainville, Louis-Antoine de. Voyage autour du monde par la Frigate, La Boudeuse et La Flute L'Étoile. Paris: La Découverte, 1997 [1771].

- Adventure in the wilderness: the American journals of Louis Antoine de Bougainville, 1756-1760, translated and edited by Edward P. Hamilton. Norman, Oklahoma: University of Oklahoma Press, 1964.

Bourlet, Antoine. "Funérailles chez les Thay." Anthropos, vol. VIII, pp. 40-46, 1913.

—. "Les Thay: I. Vie intime du Thay, sa famille." Anthropos, vol. II, no. 3, pp. 355-373, 1907a.

—. "Les Thay: II. Vie publique du Thay, les rapports avec les chefs; III. Vie religieuse du Thay." Anthropos, vol. II, nos. 4-5, pp. 613-632, $1907 \mathrm{~b}$.

- "Les Thay: IV. Origine des Thay d'après les mythes et légendes." Anthropos, vol. II, no. 6, pp. 921-932, 1907c.

_ . "Socialisme dans les hua phan (Laos, Indo-Chine)." Anthropos, vol. I, pp. 87-94, 1906.

Boutilier, J.A., D.T. Hugues, S.W. Tiffany (eds). Mission, Church, and Sect in Oceania. Ann Arbor: University of Michigan Press, 1978. 
Brébeuf, Jean de, Écrits en Huronie, Montréal: Bibliothèque québécoise, 1996 [16351636].

Brebion, Antoine. Dictionnaire de bio-bibliographie générale, ancienne et moderne, de l'Indochine francaise. Annales de l'Académie des Sciences coloniales, Vol. VIII. Paris: Société d'éditions géographiques, maritimes et coloniales, 1935.

Bridgman, E.C. "Sketches of the Miau-tsze." Fournal of the Royal Asiatic Society, North China Branch, vol. 3, pp. 257-86, 1859.

Brisson, Théodule. "La propriété chez les peuplades du Lac-thô." Revue Indo-Chinoise, no. 7, 1904.

__ "Le Lac-thô, étude." Annales de la Société des Missions étrangères, nos. 28-29, 1902.

British Association for the Advancement of Science (ed.). Notes and Queries on Anthropology for the use of Travellers and Residents in Uncivilized Lands. London: Edward Stanford, 1874 .

Broumton. "A Visit to the Miao-Tsze. Tribes of South China." Proceedings of the Royal Geographic Society 3:225-226, 1881.

Burridge, Kenelm. "Missionaries and the Perception of Evil." In Missionaries, Anthropologists, and Cultural Change, ed. D. Whiteman, Williamsburg: College of William and Mary, pp. 153-170, 1985.

Cadière, Léopold. "Instructions pratiques pour les missionnaires qui font des observations religieuses." Annales de la Société des Missions Étrangères de Paris, nos. 92-93-94, 1913.

_. "La Semaine d'Ethnologie religieuse tenue à Louvain." Les Missions Catholiques, 493-495, 1912.

Cao Huy Thuan. Les missionnaires et la politique coloniale française au Vietnam (1857-1914). New Haven: Council on Southeast Asia studies; Amiens: Centre de relations internationales et de science politique, 1990.

Chappoulie, Henri. Rome et les missions d'Indochine au XVII siècle. Paris: Bloud et Gay, 1943.

Charlevoix, Pierre François-Xavier de. Histoire et description générale de la Nouvelle-France, avec le journal historique d'un voyage fait par ordre du roi dans l'Amérique septentrionale. Paris: Rolin Fils, 6 volumes, 1744 .

Chavannes, Alexandre César, Anthropologie ou science générale de l'homme, pour servir d'introduction à l'étude de la philosophie et des langues et de guide dans le plan d'éducation intellectuelle. 13 volumes, Lausanne, 1788.

Clifford, James. "Traveling Cultures." In Cultural Studies, eds. Grossberg, L., C. Nelson and P. Teichler, London and New York: Routledge, 1992.

- Person and Myth: Maurice Leenhardt in the Melanesian World. Berkeley: University of California Press, 1982.

Clifford, James, and George E. Marcus (eds). Writing culture: The poetics and Politics of Ethnography. Berkeley, CA: University of California Press. 1986.

Collective. "Ethnographie indochinoise." Synthèse collective à l'occasion du $20^{\mathrm{e}}$ anniversaire du BEFEO, vol. XXI, pp. 167-196, 1921.

Collective. Relations des fésuites en Nouvelle-France. Paris et Rouen: Cramoizy, 41 volumes, 1632-1673.

Colquhoun, Archibald R. Across Chrysê. A Journey of Exploration through the South China Border Lands from Canton to Mandalay. London: Sampson Low, Marston, Searle and Rivington, 2 volumes, 1883.

Comaroff, J. and J. Comaroff. Of Revelation, and Revolution: Christianity, Colonialism, and Consciousness in South-Africa, vol. 1. Chicago: University of Chicago Press, 1991.

Condominas, Georges. "Deux grands ethnologues pratiquement inconnus de la profession: les pères François Callet et Léopold Cadière." In Histoire de l'Anthropologie XVI-XIX ${ }^{e}$ siècles, ed. Rupp-Eisenreich, B., Paris: Klinsksieck, 1984.

—. L'espace social. À propos de l'Asie du Sud-Est. Paris: Flammarion, 1980. 
1976.

Conklin, Alice L. A Mission to Civilize. The Republican Idea of Empire in France and West Africa, 1895-1930. Stanford: Stanford University Press, 1997.

Copans, Jean. Anthropologie et impérialisme. Paris: Maspero, 1975.

Copans, Jean and Jean Jamin. Aux origines de l'anthropologie française: Les mémoires de la Société des observateurs de l'Homme en l'an VIII. Paris: Les cahiers Gradhiva, no. 23, Jean-Michel Place, 1993 [1978].

Cordier, Henri. Les Lolos. Etat actuel de la question. Leiden: Brill, T’oung-pao série II, vol. VIII, no. 5, 1907.

Courtois, Luc. "La première semaine d'ethnologie religieuse à Louvain en 1912. Les débuts difficiles d'une démarche progressiste sur fond de crise moderniste." In Anthropologie et missiologie: $X I X^{e}-X X^{e}$ siècles: entre connivence et rivalité, eds. Servais, Olivier and Spijker, Gérard van 't. Paris: Karthala, collection Mémoire d'Églises, 95-118, 2004.

Crawford, T.P. "The Miao-tsz, or Aborigines of China." China Recorder, vol. 10, no. 5, pp. 385-7, 1879.

Guisinier, Jeanne. Les Müong. Paris: Institut d'Ethnologie, Géographie humaine et sociologie, 1946.

Culas, Christian. Le Messianisme hmong aux XIX et $X X^{e}$ siècles. La dynamique religieuse comme instrument politique. Paris: CNRS Éditions, 2005.

Culas, Christian and Jean Michaud. "A contribution to the study of Hmong (Miao) migrations and history." In Hmong/Miao in Asia, eds Tapp, N., Michaud, J., Culas, C., Lee, G.Y. Chiang Mai: Silkworm, pp. 61-96, 2004.

Cupet, Pierre-Paul. Voyages au Laos et chez les sauvages du sud-est de l'Indo-Chine. Vol. 3 of Mission Pavie - Géographie et voyages, Paris: Ernest Leroux, 1900.

D’Abrigeon, Pierre. "Un bal chez les Méo." Les Missions Catholiques, pp. 378-9, 1919.

D’Ollone, Henri. Écritures des peuples non chinois de la Chine; Quatre dictionnaires Lolo et Miao Tseu. Mission d'Ollone 1906-1909. Paris: Ernest Leroux, 1912a.

- Langues des peuples non chinois de la Chine. Mission d'Ollone 1906-1909. Paris: Ernest Leroux, 1912b.

D’Orléans, Henri-Philippe-Marie. Autour du Tonkin. Paris: Calmann-Lévy, 1894.

Dang Phuong-Nghi. Les institutions publiques du Viêt-Nam au XVIII siècle. Paris: École française d'Extrême-Orient, 1969.

Darwin Charles. On the Origin of Species by Means of Natural Selection, or the Preservation of Favoured Races in the Struggle for Life. London: John Murray, 1859.

De Certeau, Michel. "History and Anthropology in the Works of Lafitau." Yale French Studies, no. 59 (Rethinking History), 1980.

De Gérando, Joseph-Marie. Considérations sur les diverses méthodes à suivre dans l'observation des peuples sauvages. Paris: Société des observateurs de l'homme, an VIII, 1799.

De Lanessan, Jean-Marie-Antoine. L'Indochine française, étude politique et administrative. Paris: Alcan, 1889.

- La colonisation française en Indo-Chine. Paris: Alcan, 1895.

De Rhodes, Alexandre. Tonquinensis historiae libri dvo (...), Lyon: K.B. Denvenet, 1652.

- Le catéchisme en langue vietnamienne romanisée, 1651. Roma, Université Grégorienne, 1956-1957.

Deka, W. "Spoken language of the Miau-tsze and other aborigines," Notes and Queries on China and Japan, vol. 1, 1867.

Delfendahl, Bernard. "On Anthropologists versus Missionaries." Current Anthropology, vol. 22, no. 1, pp. 89-90, 1981.

Devéria, Gabriel. "Les Lolo et les Miao-Tze. A propos d'une brochure de M.P. Vial, missionnaire apostolique au Yun-nan." Journal asiatique, 8e série, vol. 18, pp. 356-69, 1891. 
La frontière sino-annamite, description géographique et ethnographique d'après les documents officiels chinois. Paris: Publications de l'Ecole des Langues orientales, tome 1, 1886.

Diderot, Denis (ed.). Encyclopédie, ou dictionnaire raisonné des sciences, des arts et des métiers, par une société de gens de lettres. Paris: Libraires associées. 17 volumes, 1751-1765.

Diguet, Edouard. Les Montagnards du Tonkin. Paris: Librairie Maritime et Coloniale, Augustin Challamel, 1908.

Donnelly, J.P. Fean de Brébeuf, 1593-1649. Chicago: Loyola University Press, 1975.

Dourisboure, Pierre. Dictionnaire Bahnar-Français. Hong Kong: Imprimerie des Missions étrangères, 1889.

- Les sauvages Ba-hnars, Cochinchine orientale. Lyon, Lecoffre, 1875.

Doutreligne, Denis. "L'ethnologie et les missionnaires. A propos de deux réunions: Tilburg (1922), Paris (1923)." Bulletin de la Société des Missions-Etrangères de Paris no. 33, septembre, pp. 549-554, 1924.

Duchet, Michèle. Anthropologie et histoire au siècle des lumières. Buffon, Voltaire, Rousseau, Helvétius, Diderot. Paris: François Maspero, 1971.

Dupuis, Jean. L'ouverture du Fleuve Rouge au commerce et les événements du Tong-Kin, 1872-1873. Journal de voyage et d'expédition de J. Dupuis, 1879.

Eckert, Henri, Les militaires indochinois au service de la France (1859-1939). PhD dissertation in History, Université de Paris IV (France). 1998.

Edkins, J. "The Miau-tsi, their history." China Recorder, vol. 2, 1871.

Evans-Pritchard, Edward E. A History of Anthropological Thought. Edited by André Singer with an introduction by Ernest Gellner. New-York: Basic Books, 1981.

- The Nuer. A Description of the Modes of Livelihood and Political Institutions of a Nilotic People. New York and Oxford: Oxford University Press, 1971 [1940].

Fanon, Franz. Les damnés de la Terre. Paris: François Maspéro, 1961.

Feuchtwang, Stephan. "The Colonial Formation of British Social Anthropology." In Anthropology and the Colonial Encounter, ed. Asad, Talal, London: Ithaca Press, Atlantic Highlands: Humanities Press, pp. 72-100, 1973.

Figuet, Paul-Pierre-Marie. "Un extraordinaire chef de révoltés." Annales de la Société des Missions étrangères, no. 28, juillet-août 1902.

Forest, Alain. Les missionnaires francais au Tonkin et au Siam (XVII $-X V I I I^{e}$ siècles). Analyse comparée d'un relatif succès et d'un échec total. Livre II-Histoires du Tonkin. Paris: L'Harmattan, 1998.

Foster, Peter. "Politics, Ethnography, and the 'Invention of Tradition': The Case of T. Cullen Young of Livingstonia Mission, Malawi." Special issue of History and Anthropology, vol. 8, nos. 1-4, pp. 299-320, 1994.

Fourniau, Charles. "La frontière sino-vietnamienne et le face à face franco-chinois à l'époque de la conquête du Tonkin." In Les frontières du Vietnam/Histoire des frontières de la péninsule indochinoise, ed. Lafont, P.B., Paris: L'Harmattan, pp. 85-103, 1989.

Garnier, Francis. Album pittoresque, first part of Atlas du voyage d'exploration en Indo-Chine. Paris: Librairie Hachette, 1873a.

- Voyage d'exploration en Indo-Chine. Tome II. Paris: Librairie Hachette, 1873b.

Gay, Bernard. "La frontière vietnamo-lao de 1893 à nos jours." In Les frontières du Vietnam/ Histoire des frontières de la péninsule indochinoise, ed. Lafont, P.B., Paris: L'Harmattan, pp. 204-232, 1989.

Girardet, Raoul. L'idée coloniale en France de 1871 à 1962. Paris: Hachette, 2005.

Girod, Léon "Une tournée dans la région située au N.-O. de Lao-Kay." Les Missions Catholiques, pp. 472-75; 481-90; 497-500; 510-15; 526-28; 533-37, 1902.

—. Souvenirs franco-tonkinois 1879-1886. Paris: Desclée, de Brouwer \& Cie, 1900. . Dix ans de Haut-Tonkin. Paris: A. Mame et Fils, 1899.

Guennou, Jean. Missions étrangères de Paris. Paris: Fayard, 1986.

Guerlach, Jean. "Moeurs et superstitions des Bahnars. Journal de voyage de M. Guerlach." Les Missions catholiques, vol. 19, pp. 441-527, 1887.

Guiart, Jean. "Comments on Stipe." Current Anthropology, vol. 21, no. 2, pp. 170-1, 1980. 
Hall, D.G.E. A History of South-East Asia. New York: St-Martin's Press, 4th edition, 1981.

Harmand, Jules. "De l'état de l'ethnographie indochinoise." Revue d'études ethnographiques et sociologiques 4:55, 1912.

Harrison, Robert P. Forests: The Shadow of Civilisation. Chicago: University of Chicago Press, 1992.

Haudricourt, André Georges. Le vocabulaire bê de F.M. Savina, Paris, EFEO, 170p. 1965.

Hennepin, Louis. Nouvelle découverte d'un très grand pays situé dans l'Amérique, entre le Nouveau Mexique et la mer glaciale, avec cartes et figures, l'histoire naturelle et morale, et les avantages que l'on peut tirer par l'établissement des Colonies. Utrecht: G. Broedelet, 1697.

—_. Description de la Louisiane, nouvellement découverte au sud-ouest de la Nouvelle-France par ordre du roi, avec la carte du pays, les moeurs et la manière de vivre des sauvages. Paris: Veuve Sébastien Hure, 1683.

Hervey de St-Denis. "Ethnographie des Miao-Tze." Compte-rendus du Congrès des Orientalistes, vol. 1, pp. 354-63, 1875.

Hickey, Gerald C. Sons of the Mountains. Ethnohistory of the Vietnamese Central Highlands to 1954. New Haven and London: Yale University Press, 1982a.

- Free in the Forest. Ethnohistory of the Vietnamese Central Highlands, 1954-1976. New Haven and London: Yale University Press, 1982b.

Hiebert, Paul. "Missions and Anthropology: A Love/Hate Relationship." Missiology, vol. 6, no. 2, pp. 165-80, 1978.

Hocquart, Charles-Edouard, "Trente mois au Tonkin." Tour du Monde, ler semestre, 1890.

Huber, Mary T. The Bishops' Progress. A Historical Ethnography of Catholic Missionary Experience on the Sepik Frontier. Washington and London: Smithsonian Institute Press, 1988.

Hudspeth, William H. "The Cult of the Door amongst the Miao." Folklore, vol. 33, pp. 406-10, 1922.

James, Wendy. "The Anthropologist as Reluctant Imperialist." In Anthropology and the Colonial Encounter, ed. Asad, Talal, London: Ithaca Press, Atlantic Highlands: Humanities Press, pp. 42-69, 1973.

Jamin, Jean. "Naissance de l'observation anthropologique, la société des observateurs de l'homme (1799-1805), Cahiers Internationaux de Sociologie, vol. 67, pp. 31-53, 1979.

Jourdain, Denis. Grammaire franco-annamite. Saigon: Imprimerie du Gouvernement, 1872.

Junod, H.P. "Anthropology and Missionary Education." International Review of Missions, vol. 24, pp. 213-28, 1935.

Kennedy, John H. Jesuit and Savage in New France. New Haven: Yale University Press, 1950.

Khong Dien. Population and Ethno-demography in Vietnam. Chiang Mai: Silkworm Books, 2002.

Kleinen, John. "Ethnographic Praxis and the Colonial State in Vietnam." In Viêt Nam. Sources et approches, eds. Lefailler, P. and J.-M. Mancini, Aix-en-Provence: Université de Provence, 1996.

Kunstadter, Peter (ed.). Southeast Asian Tribes, Minorities and Nations. Princeton: Princeton University Press, 1967.

La Bissachère, Pierre-Jacques Lemonnier de. Etat actuel du Tun-Kin, de la Cochinchine et des royaumes de Cambodge, Laos, Lac Tho. Paris: Galignani, 2 volumes, 1818.

- (compiled by N. de Montyon). Exposé statistique du Tonquin, de la Cochinchine, du Cambodge, du Tsiampa, du Laos, du Lac Tho. Londres: Dulau, 1811.

La Salle, Robert Cavelier de. Relation of the Discoveries and Voyages of Chevalier de le Salle from 1679 to 1681, the Official Narrative. Melville B. Anderson, translator. Chicago, IL: The Caxton Club, 1901.

Laburthe-Tolra, Philippe. "Pourquoi et comment un lien inextricable existe entre anthropologie et mission chrétienne." In Anthropologie et missiologie: XIX ${ }^{e}-X X^{e}$ siècles: 
entre connivence et rivalité, eds. Servais, Olivier \& Gérard van 't Spijker, Paris: Karthala, collection Mémoire d'Églises, pp. 15-24, 2004.

__. "L'ethnologue Alexandre Le Roy (1854-1938)." Mémoire spiritaine, vol. 12, Second semester, pp. 62-71, 2000.

Lafitau, Pierre-François. Moeurs des sauvages amériquains, comparées aux moeurs des premiers temps. Annotated by Edna Hindie Lemay. Paris: François Maspero, 2 volumes, 1983 [1724]. Published in English as: Customs of the American Indians Compared with the Customs of Primitive Times, vol. II, edited and translated by W.N. Fenton and E. Moore, Toronto: The Champlain Society, 1977.

Lange, Claude. "Croyances et pratiques religieuses des Vietnamiens. L'œuvre du père Léopold Cadière (1869-1955)." In Anthropologie et missiologie: XIX ${ }^{e}-X X^{e}$ siècles: entre connivence et rivalité, eds. Servais, Olivier \& Gérard van 't Spijker, Paris: Karthala, collection Mémoire d'Églises, Pp. 211-228, 2004.

Latourelle, René. Jean de Brébeuf. Montréal: Bellarmin, 1993.

- Études sur les écrits de saint Jean de Brébeuf. Montréal: Éditions de l'ImmaculéeConception, 2 volumes, 1953.

Latourette, Kenneth S. A History of Christian Missions in China. London: Society for promoting Christian Knowledge, 1929.

Launay, Adrien. Mémorial de la Société des Missions Étrangères. Paris: MEP, 1916.

- Atlas des missions de la Société des Missions Étrangères de Paris. Lille: Desclée, de Brouwer et Cie, 1890.

- Histoire ancienne et moderne de l'Annam. Paris: Challamel, 1884.

Lê, Nicole-Dominique. Les Missions-Étrangères et la pénétration française au Viet-Nam. Paris: Mouton, 1975.

Le Jeune, Paul. Relation de ce qui s'est passé en la Nouvelle France en l'an 1634. Paris: Sébastien Cramoizy, 1635.

Le Roy Alexandre. La Religion des primitifs, Paris: Gabriel Beauchesne et Cie, 1909.

__ "Le rôle scientifique des Missionnaires." Anthropos vol. I, pp. 3-10, 1906.

Lê Thàn Khôi. Histoire du Viêt Nam des origines à 1858. Paris: Sudestasie, 1981 [1971].

Lebar, F.M., G.H. Hickey and J.K. Musgrave (eds.). Ethnic Groups of Mainland Southeast Asia. New Haven: Yale University Press, Human Relations Area Files, 1964.

Leclerc, Gérard Anthropologie et colonialisme: essai sur l'histoire de l'africanisme. Paris: Fayard, 1972.

Lefèvre-Pontalis, Pierre. "L'invasion Thaie en Indochine, $2^{\text {ème }}$ partie." T'oung Pao, October, pp. 495-512, 1909.

- Voyage dans le Haut-Laos et sur les frontières de Chine et de Birmanie. Introduction by Auguste Pavie. Volume 5 of the Géographie et voyages section of Mission Pavie Indo-Chine 1879-1895, Paris: Ernest Leroux, 1902.

_ . "L'invasion Thaïe en Indochine, lère partie." T'oung Pao, March, pp. 53-78, 1897.

"Notes sur quelques populations du nord de l'Indo-Chine (2 $2^{\text {ème }}$ série)." Extrait du Fournal asiatique, Paris: Ernest Leroux, 1896.

—_. "Notes sur quelques populations du nord de l'Indo-Chine (1 ${ }^{\text {ère }}$ série)." Extrait du Fournal asiatique, Paris: Ernest Leroux, 1892.

Legendre, A.-F. Le far-west chinois. Kientchang et Lolotie, Chinois, Lolos, Sifans. Impressions de voyage. Etude géographique, sociale et économique, $3^{\text {e }}$ édition. Paris: Plon, 1910.

Leiris, Michel. "L'ethnographe devant le colonialisme." Les temps modernes, vol. 6, no. 58, pp. 357-74, 1950.

Lewis, Diane. "Anthropology and Colonialism." Current Anthropology, vol. 14, pp. 581-91, 1973.

$\mathrm{Li}$, Shenwen. Stratégies missionnaires des jésuites français en Nouvelle France et en Chine au XVII ${ }^{e}$ siècle. Paris: L'Harmattan, 2003.

Liétard, Alfred. Au Yun-nan: Les Lo-lo p’o. Une tribu des aborigènes de la Chine méridionale. Münster: Aschendorffsche Verlagsbuchhandlung, Anthropos Bibliothek, 280p. 1913a. 
Essai de dictionnaire Lolo-Français reproduisant le dialecte parlé par la tribu des 'A-Hi'. Suivi d'un vocabulaire Français-Lo-lo (A-Hi). [Extracts from T'oung Pao vol. XII \& XIII]. Leide: E.J. Brill, 194p. 1913b.

"Au Yun-nan, Min-kia et La-ma jen.” Anthropos, vol. VII, pp. 677-705, 1912a.

"Notions de grammaire Lolo, dialecte A-hi." and "Vocabulaire français-lolo, dialecte A-hi." T'oung Pao, vol. XIII, pp. 1-627, 1912b.

—. "Essai de dictionnaire lolo-français, dialecte A-hi." T'oung Pao, vol. XII, (several issues), pp. 1, 123, 316, 544, 1911. 1909.

. "Notions de grammaire lolo (Dialecte A-hi)." BEFEO, vol. IX, pp. 123-156, . "Le district des Lolos A-chi.", part 1. Les Missions Catholiques 1811:93-96, 1904.

Lockhart, William. "On the Miau-tze or Aborigines of China." L'Année géographique, vol. 1, pp. 297-306, 1863.

Lombard-Salmon, Claudine. Un exemple d'acculturation chinoise: la province du Guizhou au XVIII ${ }^{e}$ siècle. Paris: École française d'Extrême-Orient, 1972.

Louvet, Louis Eugène. Vie de Mgr Puginier, Évèque de Mauricastre, Vicaire Apostolique du Tonkin Occidental. Hanoi: Schneider, 1894.

Lowie, Robert H. The History of Ethnological Theory. New York: Rinehart \& Co., 1937.

Lunet de Lajonquière, Emile. Ethnographie du Tonkin septentrional (Rédigé sur l'ordre de M.P. Beau, Gouverneur Général de l'Indo-Chine Française, d'après les études des administrateurs civils et militaires des provines septentrionales). Paris: Ernest Leroux, 1906.

—_. Ethnographie des territoires militaires (Rédigé sur l'ordre du Général Coronat d'après les travaux de M.M. le Lieutenant-Colonel Diguet, le Commandant Révérony, le Capitaine Fesh et al.). Hanoi: F.H. Schneider, 1904.

Luzbetak, L.J. "Towards an Applied Missionary Anthropology." Anthropological Quarterly, vol. 34, pp. 165-76, 1961.

Ma Touan Lin. Ethnographie des peuples étrangers à la Chine, texte du XIII ${ }^{e}$ siècle traduit du chinois et annoté par le Marquis d'Hervey de Saint-Denys. Paris: Ernest Leroux, 1883.

Maire, Edouard. "Mission du Yunnan. Traditions et souvenirs. Bulletin de la Société des Missions-Étrangères de Paris, vol. 1. Pp. 10-16, 48-55, 70-76, 134-142, 206-215, 346-355, 403-410, 524-533, 592-603, 651-661.

Malinowski, Bronislaw. Argonauts of the Western Pacific. An Account of Native Enterprise and Adventure in the Archipelagoes of Melanesian New Guinea. London: Routledge and Kegan Paul, 1922b.

Martin, Jean-Marie. "Relation sur le Laos." Les Missions catholiques, no. 1560 ss., 1899.

_ _ "Au Laos, Song Ma, Song Dhiel." Les Missions catholiques, nos. 1582-1586, 1901.

Mauss, Marcel. Euvres-3: Cohésion sociale et divisions de la sociologie. Paris: Editions de Minuit, 1969.

—. Manuel d'ethnographie. Paris: Petite bibliothèque Payot, 1967 [1947].

. 'Essai sur le don. Forme et raison de l'échange dans les sociétés archaïques', Année sociologique, 2(1), pp. 30-186. 1923-1924.

. "L'ethnographie en France et à l'étranger." La Revue de Paris, vol. 20, pp. 537-60, 815-37, 1913.

_. "Essai d'une instruction pour l'étude sociologique des sociétés indo-chinoises." In Premier Congrès International des Etudes sur l'Extrême-Orient, 1902, Hanoi: Schneider, pp. 92-3, 1903.

. Carnet Instruction pour les collaborateurs de l'École française d'Extrême-Orient. Saigon: Imprimerie Ménard et Legros, 1900.

Mauss, Marcel et Auguste Bonifacy. Questionnaire de l'École française d'Extrême-Orient. Hanoi: Imprimerie d'Extrême-Orient, 1903. 
Mayeur, Jean-Marie and Madeleine Rebérioux. The Third Republic from its Origins to the Great War, 1871-1914. Cambridge: Cambridge University Press, 1984.

McAleavy, Henry. Black Flags in Vietnam. The Story of a Chinese Intervention. London: George Allen and Unwin Ltd., 1968.

McAlister, John T., Jr. "Mountain Minorities and the Viet Minh: A Key to the Indochina War." In Southeast Asian Tribes, Minorities, and Nations, ed. Peter Kunstadter. Princeton: Princeton University Press, 1967.

Méchet, Louis. "Léon-Xavier Girod, missionnaire du Haut Tonkin." Bulletin de la Société des Missions-Étrangères, pp. 408-416, 472-480, 539-546, 597-605, 1925.

Menget, Patrick. "Histoire de l'Anthropologie." In Dictionnaire de l'Ethnologie et de l'Anthropologie, eds. Bonte, P. \& M. Izard, Paris: Presses universitaires de France, 328-332, 1991.

Métraux, Alfred. "Les précurseurs de l'ethnologie en France, du XVI ${ }^{\mathrm{e}}$ au XVIII siècle." Cahiers d'histoire mondiale, vol. VII, pp. 721-738, 1963.

Michaud, Jean. Historical Dictionary of the Peoples of the Southeast Asian Massif. Lanham: Scarecrow Press. 2006.

_ . "French Missionary Expansion in Colonial Upper-Tonkin." Fournal of Southeast Asian Studies. vol. 35, no. 2:287-310, 2004a.

_ . "Missionary Ethnographers in Upper-Tonkin: The Early Years." Asian Ethnicity. vol. 5, no. 2:179-194, 2004b.

—. "The Montagnards in Northern Vietnam from 1802 to 1975. A Historical Overview from Exogenous Sources." Ethnohistory, vol. 47, no. 2, 2000.

Miller, E.S. "The Christian Missionary: Agent of Secularization.” Anthropological Quarterly, vol. 43, no. 1, pp. 14-22, 1970.

_. "Great was the Company of the Preachers: the Word of Missionaries and the Word of Anthropologists." Anthropological Quarterly, vol. 54, no. 3, pp. 125-33, 1981.

Monteuuis, Gustave. L'âme d'un missionnaire. Vie du P. Nempon, missionnaire apostolique du Tonkin Occidental. Paris: Victor Retaux et Fils, 1895.

Moore, F.T.C. (ed.). The Observation of Savage People by 7.-M. de Gérando. Preface by E.E. Evans-Pritchard, Berkeley: University of California Press, 1969.

Moréchand, Guy. "Le chamanisme des Hmong." BEFEO, vol. LIV, pp. 53-294, 1968.

Morrison, George E. An Australian in China. London: Horace Cox, 1895.

Motsch, Andreas. Lafitau et l'émergence du discours ethnographique. Québec and Paris: Septentrion and Presses de l'Université de Paris-Sorbonne, 2001.

Mus, Paul. "Review of Savina's 'Monographie de Hainan'." BEFEO, vol. XXX, pp. 436-44, 1930.

Ngo Gia Van Phai Unification du Royaume sous les Lê. Paris: Ecole française d'ExtrêmeOrient, 1996.

Nguyên Thê Anh. "L'image de la piraterie tonkinoise dans la litterature coloniale." In Rêver l'Asie. Exotisme et litterature coloniale aux Indes, en Indochine et en Insulinde, ed. Lombard, Denys, Paris: École des Hautes Etudes en Sciences Sociales, pp. 179-93, 1993.

Nida, Eugene A. "Missionaries and Anthropologists." Practical Anthropology, vol. 13, pp. 273-7,287, 1966.

_ . "The Role of Cultural Anthropology in Christian Missions." In Readings in Missionary Anthropology II, ed. Smalley, W.A., South Pasadena: W.Carey Library, 1978 [1959].

Osborne, Milton. River Road to China. The Mekong River Expedition, 1866-73. London: Allen and Unwin, 1975.

Papin, Philippe. Histoire de Hanoi. Paris: Fayard, 2001.

Pavie, Auguste. A la conquête des coeurs. Paris: Presses Universitaires de France, 1947.

Pavie, Auguste et al. I- Mission Pavie en Indochine. Etudes diverses. 3 volumes; II-Mission Pavie. Géographie et voyages. Paris: Ernest Leroux, 7 volumes, 1898-1903. 
Pels, Peter. "The Anthropology of Colonialism: Culture, History, and the Emergence of Western Governmentality.” Annual Review of Anthropology, vol. 26, pp. 163-83, 1997. - "Anthropology and Mission: Towards a Historical Analysis of Professional Identity.' In The Ambiguity of Rapprochement. Reflections of Anthropologists on their Controversial Relationship with Missionaries, eds. Bonsen, R., H. Marks and J. Miedema, Nijmegen: Focaal. 1990.

Pels, Peter and Oscar Salemink (eds). Colonial Subjects: Essays on the Practical History of Anthropology. Ann Arbor: University of Michigan Press, 1999.

. "Introduction: Five Theses on Ethnography as Colonial Practice." History and Anthropology, vol. 8, nos.1-4, pp. 1-34, 1994.

Petersen, Glenn T. "Comments on Stipe." Current Anthropology, vol. 21, no. 2, pp. 173, 1980.

Pinabel, Pierre-Charles. "Notes sur quelques peuplades sauvages dépendant du TongKing." Bulletin de la société de Géographie de Paris, $7^{\mathrm{e}}$ série, vol. 5, pp. 417-33, 1884.

Poirier, Jean. "Histoire de la pensée ethnologique." In Ethnologie générale, ed. Poirier, Jean. Paris: Editions Gallimard, Encyclopédie de la Pléiade, pp. 3-179, 1968.

Pollard, Samuel. The Story of the Miao. London: Henry Hooks, 1919.

Pouliot, Léon. Etudes sur les Relations des fésuites de la Nouvelle-France (1632-1672). Paris: Desclée de Brouwer, 1940.

Quach-Langlet, T. "Le cadre géographique de l'ancien Campa." Actes du séminaire sur le Campa, Université de Copenhague, le 23 Mai 1987, pp. 28-48, Paris: Travaux du Centre d'Histoire et Civilisations de la Péninsule Indochinoise, 1988.

Quatrefages de Bréau, J.-L. Armand de. L'espèce humaine. Paris, Librairie Germer Baillière, 1883.

—. "Anthropologie.". In Société de Géographie. Instructions générales aux voyageurs, Paris: Delagrave, pp. 244-58,1875.

Rabinow, Paul. "Facts are a Word of God." In Observers Observed, ed. Stocking, George. Madison: University of Wisconsin Press, "History of Anthropology" series vol. 1, pp. 196-207, 1983.

Radisson, Pierre-Esprit. Voyages of Peter Esprit Radisson being on count of his Travels and Experiences among the North American Indians from 1652 to 1684. New York: Smith, 1943 [1885].

Ravier, Marcel Henri. Dictionarium latino-anamiticum completum et novo ordine dispositum, Ninh-phu: Imprimerie des Missions du Tonkin occidental, 1880.

Raynal, Guillaume-Thomas, abbé de. Histoire philosophique et politique des établissements et du commerce des Européens dans les Deux Indes. Neufchâtel: Libraires associés, 10 volumes, 1783.

Rivers, William H. "Anthropology and the Missionary." Church Missionary Review, vol. 71, pp. 208-15, 1920.

. "Report on Anthropological Research Outside America." In Reports upon the Present Condition and Future Needs of the Science of Anthropology, eds. Rivers, W.H.R., A.E. Jenks and S.G. Morley, Washington D.C., pp. 5-28, 1913.

Rivière, Armand-Joseph. "Notes sur les Méos et sur le commerce du Mékong." Annales de Géographie, vol. III (novembre), pp. 105-7, 1893-94.

Rocher, Émile. La Province chinoise du Yün-Nan. Tome 2, Paris: Ernest Leroux, 1880. . La Province chinoise du Yün-Nan. Tome 1, Paris: Ernest Leroux, 1879.

Rousseau, Jean-Jacques. Oeuvres complètes. Du contrat social et autres écrits politiques (vol. 3, 1762). Paris: Gallimard, collection La Pléïade, 1964.

Roux, Henri. "Quelques populations du Nord Indochinois." France-Asie, vol. 92-93, 1954.

Sagard-Theodat, Gabriel. Le Grand Voyage du Pays des Hurons Situé en l'Amérique vers la Mer Douce, les Derniers Confins de la Nouvelle France dite Canada avec un Dictionaire de la Lanque Huronne (1632). Paris: Librairie Tross, 2 volumes, 1865. 
Said, Edward. "Representing the Colonized. Anthropology's Interlocutors." Critical Inquiry, vol. 15, pp. 205-25, 1989.

Salamone, F.A. "Anthropologists and Missionaries: Competition or Reciprocity?" Human Organisation, vol. 36, no. 4, pp. 407-12, 1977.

Salemink, Oscar. The Ethnography of Vietnam's Central Highlanders. A Historical Contextualization 1850-1990. London: Curzon Press, 2003.

Sarraut, Albert. "La mission civilisatrice de la France." Panorama, no. 132, 1925. La mise en valeur des colonies françaises. Paris: Payot, 1923.

Savina, François Marie. Guide linguistique de l'Indochine française. 2 vol. Hong Kong : Impr. de la Société des Missions Étrangères. XVIII.-2516p. 1939.

—_. "Lexique Day-Français accompagné d'un petit lexique Français-Day et d'un tableau des différents dialectes." BEFEO, vol. XXXI, pp. 103-199, 1931.

. Dictionnaire Français-Bê, suivi d'un lexique Ong-Bê-Français. Unpublished manuscript of 335p, [later published by André Georges Haudricourt as Le vocabulaire bê de F.M. Savina, Paris: EFEO, 170p. 1965]. 1929a.

_. Dictionnaire Hoklo-Français. Unpublished manuscript of over 1000p., 1929b.

—. Dictionnaire Hiai-Ao-Français. Unpublished manuscript, 1929c.

Monographie de Haïnan. Cahiers de la Société de Géographie de Hanoï no. 17, Hanoi: Imprimerie d'Extrême-Orient, 59p. 1929d.

—. "Dictionnaire Français-Man." BEFEO, XXVI, pp. 11-255, 1926.

- Histoire des Miao. Hong Kong: Imprimerie de la Société des Missions-Étrangères, XXII-304 p. Republished in 1930 [1924a].

_ "Considérations sur la Révolte des Miao (1918-1921)." L'Éveil Économique de l'Indochine, no. 373, 1924b.

—. Dictionnaire Étymologique Français-Nùng-Chinois. Hong Kong: Imprimerie de la Société des Missions Étrangères, XI-528 p. 1924c.

- Rapport sur la révolte des Méo du Nord Laos. Mission Catholique, Vientiane, 20 p. 1920.

——. "Dictionnaire miao-tseu-français, précédé d'un précis de grammaire miao-tseu et suivi d'un vocabulaire français-mioa-tseu." BEFEO, vol. XVI, no. 2, pp. 1-189, 1916.

—. Dictionnaire Tay-Annamite-Français, précédé d'un précis de grammaire Tay et suivi d'un vocabulaire Français-Tay. Hanoi: Schneider, XV-488, p. 1910.

Schotter, Aloys. "Notes ethnographiques sur les tribus du Kouy-tcheou (Chine) : II ${ }^{\text {ème }}$ partie: Les différentes tribus des Miao, chaps. 5-9 et Récapitulation." Anthropos, vol.VI, pp. 318-344, 1911.

- "Notes ethnographiques sur les tribus du Kouy-tcheou (Chine): II ${ }^{\text {ème }}$ partie: Les différentes tribus des Miao, chaps. 1-4." Anthropos, vol. IV, pp. 418-453, 1909.

_. "Notes ethnographiques sur les tribus du Kouy-tcheou (Chine) : Introduction." Anthropos, vol. III, pp. 397-425, 1908.

Schrauwers, Albert. Colonial 'Reformation' in the Highlands of Central Sulawesi, Indonesia, 1892-1995. Toronto: University of Toronto Press, 2000.

Schrock, Joann L. et al. Minority Groups in North Vietnam. Ethnographic Study Series. Washington D.C.: Headquarters of the Department of the Army, 1972.

Servais, Olivier and Spijker, Gérard van 't (eds). Anthropologie et missiologie: $X I X^{e}-X X^{e}$ siècles: entre connivence et rivalité. Paris: Karthala, collection Mémoire d'Églises, 2004.

Service géographique de l'Indochine. Carte ethnolinguistique (au 1:2,000,000ème). Under the supervision of EFEO. Hanoi: Service géographique de l'Indochine, 1949.

Smith, E.W. "Social Anthropology and Missionary Work." International Review of Missions, vol. 13, pp. 518-31, 1924.

Spindler, Marc, 'L'argent des missions et l'argent des chrétiens', Ad veritatem [Faculté universitaire de théologie protestante de Bruxelles], no. 27. September, pp. 2-12, 1990.

Stipe, Claude E. "Reply." Current Anthropology, vol. 23, no. 3, pp. 339-40, 1982. 
. "Anthropologists versus Missionaries: the Influence of Presuppositions." Current Anthropology, vol. 21, no. 2, pp. 165-8, 1980a.

_. "Reply." Current Anthropology, vol. 21, no. 2, pp. 176-8, 1980 b.

Stocking, George W. Jr. The Ethnographer's Magic and Other Essays in the History of Anthropology. Madison: University of Wisconsin Press, 1992.

(ed.). Colonial Situations. Essays on the Conceptualisation of Ethnographic Knowledge. Madison: University of Wisconsin Press, "History of Anthropology" series vol. 7, 1991. Victorian Anthropology. New York: the Free Press, 1987.

"The Ethnographer's Magic: Fieldwork in British Anthropology from Tylor to Malinowski." History of Anthropology, vol. 1, pp. 70-120, 1983.

—. "French Anthropology in 1800." Isis, LV(2), no. 180, pp. 134-50, 1964.

Swain, Margaret Byrne. "Native Place and Ethnic Relations in Lunan Yi Autonomous County, Yunnan." in Perspectives on the Yi of Southwest China, ed. Harrell, Stevan, Berkeley: U. of California Press, pp. 170-94, 2001.

—_. "Père Vial and the Gni-p'a. Orientalist Scholarship and the Christian Project." In Cultural Encounters on China's Ethnic Frontiers, ed. Harrell, Stevan, Seattle and London: University of Washington Press, pp. 140-85, 1995.

Tai, Hue-Tam Ho. Radicalism and the Origins of the Vietnamese Revolution. Cambridge: Harvard University Press, 1992.

Talbot, Francis. Saint among the Hurons: The Life of Jean de Brébeuf. New York: Harper \& Brothers, 1949.

Teston, Eugène and Maurice Percheron. L'Indochine Moderne: Encyclopédie administrative, touristique, artistique et économique. Paris: Librairie de France, 1931.

The Royal Anthropological Institute of Great Britain and Ireland. Notes and Queries on Anthropology, 6th edition. London: Routledge and Keegan Paul, 1951.

Thérien, Gilles. "Introduction." In Écrits en Huronie, Brébeuf, Jean de, Montréal: Bibliothèque québécoise, pp. i-lix, 1996.

Theurel, Joseph. Dictionarium anamitica-latinum, Ex opere ill. et Rev. Taberd constans; necnon ab ill. et Rev. F.S. Theurel. Ninh phu: Imprimerie des Missions du Tonkin occidental, 1877.

Thomas, Nicholas. "History and Anthropology." In Encyclopaedia of Social and Cultural Anthropology, eds. Barnard, A. and J. Spencer, London: Routledge, pp. 272-277, 1996.

Thwaites, R.G. The Fesuits Relations and Allied Documents: Travels and Explorations of the Fesuit Missionaries in New France, 1610-1791. Cleveland: Burrows Brothers Co., 73 volumes, 1896-1901 [reprinted in 1959].

Tuck, Patrick. French Catholic Missionaries and the Politics of Imperialism in Vietnam, 18571914: A Documentary Survey. Liverpool: Liverpool University Press, 1987.

Trigger, Bruce (ed.). Handbook of North American Indians. Vol. 15: Northeast. Washington: Smithsonian Institute, 1978.

- The Children of Aataentsic: A History of the Huron People to 1660. Montréal: McGillQueens University Press, 2 volumes, 1976.

Trivière, Léon. "Révérend père F.-M. Savina." Missionnaire d'Asie, pp. 25-29, 1953.

Trouwborst, A.A. "Missionaries and Ethnography." In The Ambiguity of Rapprochement. Reflections of Anthropologists on their Controversial Relationship with Missionaries, eds. Bonsen, R., H. Marks and J. Miedema, Nijmegen: Focaal, pp. 32-44, 1990.

Trudel, Serge. Étude de genèse: le cas de Premier établissement de la foi dans la Nouvelle France (1691). PhD Dissertation, Etudes françaises, Université de Montréal, 1997.

Tuck, Patrick. French Catholic Missionaries and the Politics of Imperialism in Vietnam, 18571914: A Documentary Survey. Liverpool: Liverpool University Press, 1987.

Urry, James. "Notes and Queries on Anthropology and the Development of Field Methods in British Anthropology, 1870-1920." Proceedings of the Royal Anthropological Institute. [Reprinted in: Urry, J. Before Social Anthropology: Essays on the History of 
British Anthropology. Chur, Switzerland; Philadelphia: Harwood Academic Publishers, pp. 45-57 1993], 1972.

. "A History of Field Methods." In Ethnographic Research: a Guide to General Conduct. ASA Research Methods in Social Anthropology, ed. Ellen, R.F., London: Academic Press, pp. 35-61, 1984.

van Beek, Walter E.A. "Anthropologie et missiologie ou la séparation graduelle des partenaires." In Servais, Olivier and Spijker, Gérard van 't (eds). Anthropologie et missiologie: $X I X^{e}-X X^{e}$ siècles: entre connivence et rivalité. Paris: Karthala, collection Mémoire d'Églises, pp. 25-44, 2004.

van Gennep, Arnold. "Contributions à l'histoire de la méthode ethnographique." Revue de l'histoire des religions, vol. LXVII, pp. 321-38, 1913.

Vandaële, Georges. "Mission de Hung Hoa (Tonkin)." Les Missions Catholiques, pp. 396-414, 1936.

Vermeulen, H.F. and A.A. Roldán (eds). Fieldwork and Footnotes. Studies in the History of European Anthropology. London: Routledge, 1995.

Vial, Paul. Calcul: les quatre règles expliquées aux enfants. Hongkong : Imprimerie de Nazareth, 29 p., 1913.

- Dictionnaire Français-Lolo, dialecte Gni. Hong Kong: Imprimerie de la Société des Missions Étrangères. 1909.

_. Miao-Tse et autres. Vannes: Imprimerie Lafolye Frères, 62 p. 1908.

. Petite grammaire miaotse suivi d'un petit lexique français-miaotse. Paris: Séminaire des Missions-Etrangères. 15p. 1908.

__ "Deux mois chez les Miao-tse." Les Missions Catholiques, 1908.

—. Les Lolos. Histoire, religion, møurs, langue, écriture. Etudes Sino-Orientales, part A. Shanghai: Imprimerie de la mission catholique, 1898.

- De la langue et de l'écriture indigènes au Yû-nân. Paris: Ernest Leroux, 1890.

Vo Duc Hanh. La place du catholicisme dans les relations entre la France et le Viêt Nam de 1851 à 1871. Leiden: Brill, 1969.

Wakin Eric, Anthropology Goes to War. Professional Ethics and Counterinsurgency in Thailand. University of Wisconsin, Center for Southeast Asian Studies, Monograph no. 7, Madison (USA). 1992.

Westermann, Diedrich. "The Missionary as an Anthropological Fieldworker." Africa, vol. 4, pp. 164-77, 1931.

Whiteman, D. "The Role of Ethnicity and Culture in Shaping Western Mission Agency Identity." Missiology: An International Review, Vol. 34(1), pp. 59-70, 2006.

Whiteman D. and F. Salamone (eds). Missionaries, Anthropologists, and Cultural Change. Williamsburg: William and Mary College, Studies in Third World Societies nrs. 25 \& 26, 2 volumes, 1983.

Winichakul, Thongchai. Siam Mapped. A History of the Geo-body of a Nation. Chiang Mai: Silkworm Books, 1994. 


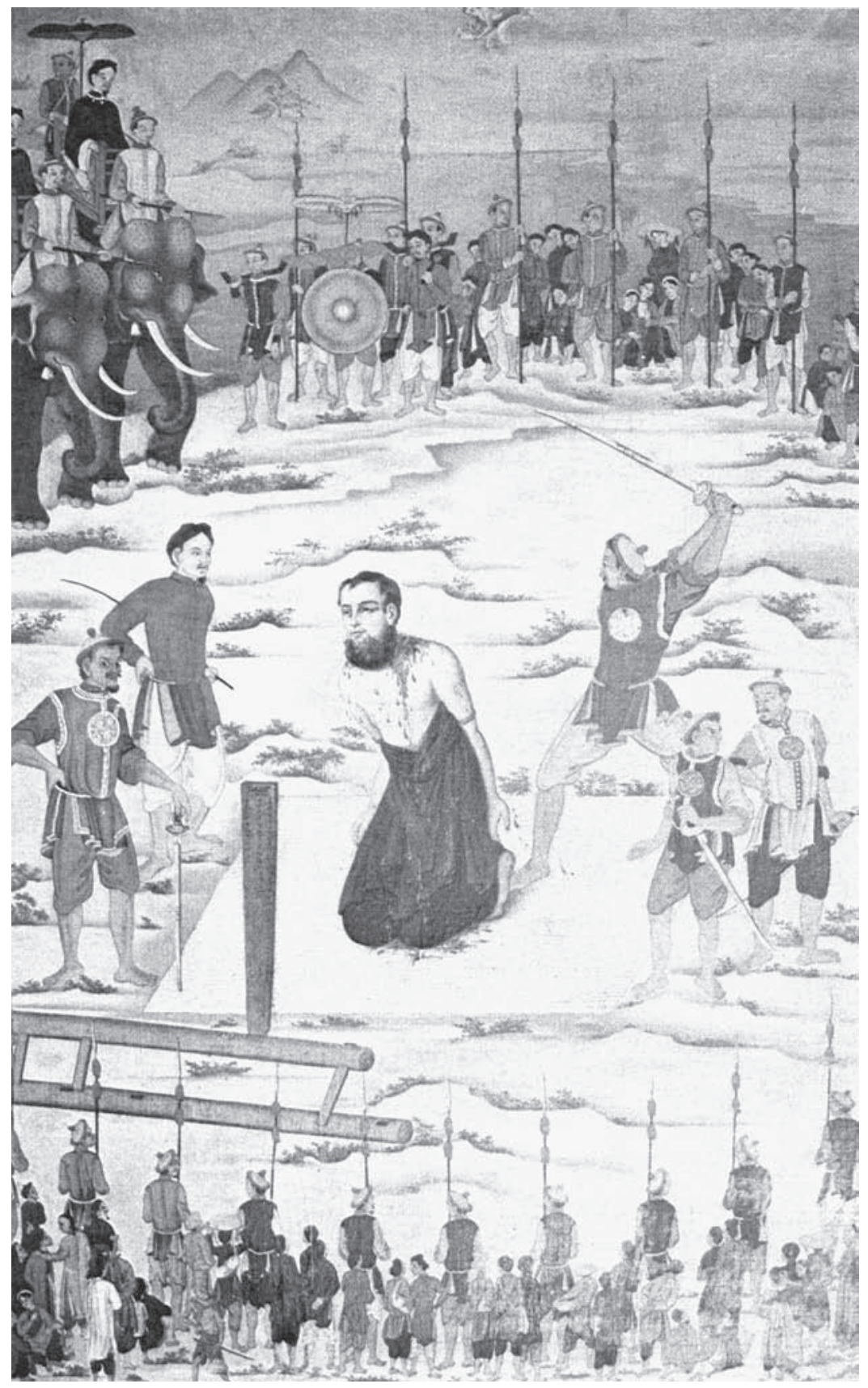

1. Execution of MEP Bishop Pierre Borie (1808-1838) in Don-hoi (Tonkin), September 24, 1838. This colour painting is shown in the Martyr Room at the MEP Seminary in Paris, and is exemplary of the 19th century movement for the emulation of young recruits. 


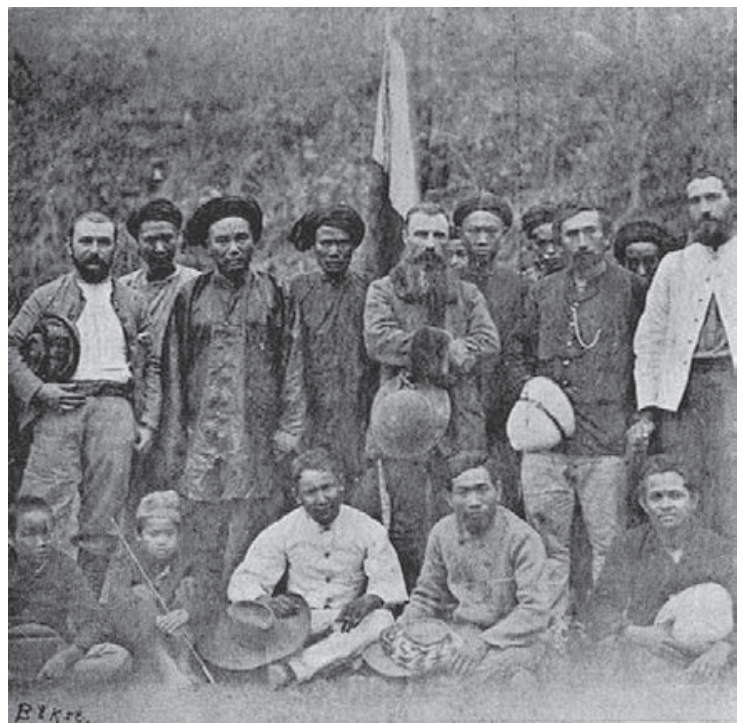

2. The Pavie Mission team in Xieng-Hung, c1891. The picture includes Auguste Pavie himself in the center under the flag, his protégé Pierre LefèvrePontalis in a white shirt on the right, and White Thai leader Deo-van-tri, second left from Pavie. Source:

Lefèvre-Pontalis, 1902.

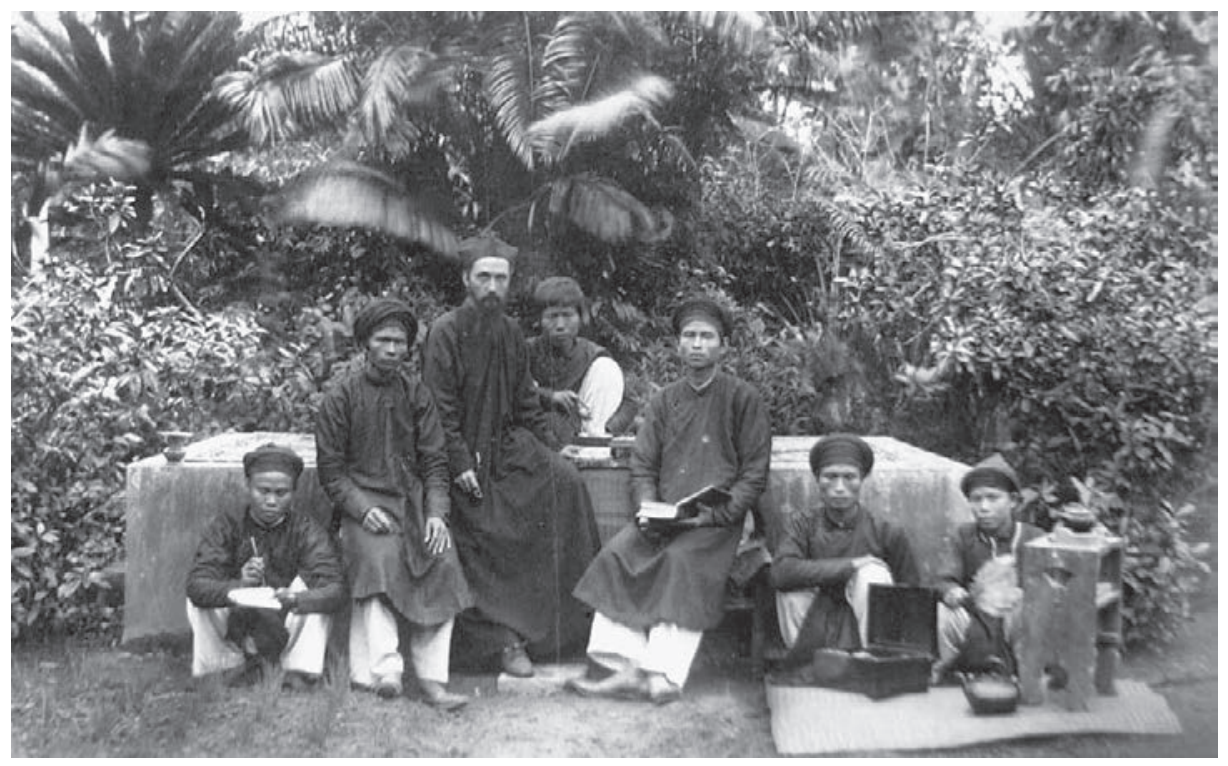

3. Father Léon Girod (1854-1924) with Kinh converts, 1885. Photographer unknown. Source: MEP Archives. 


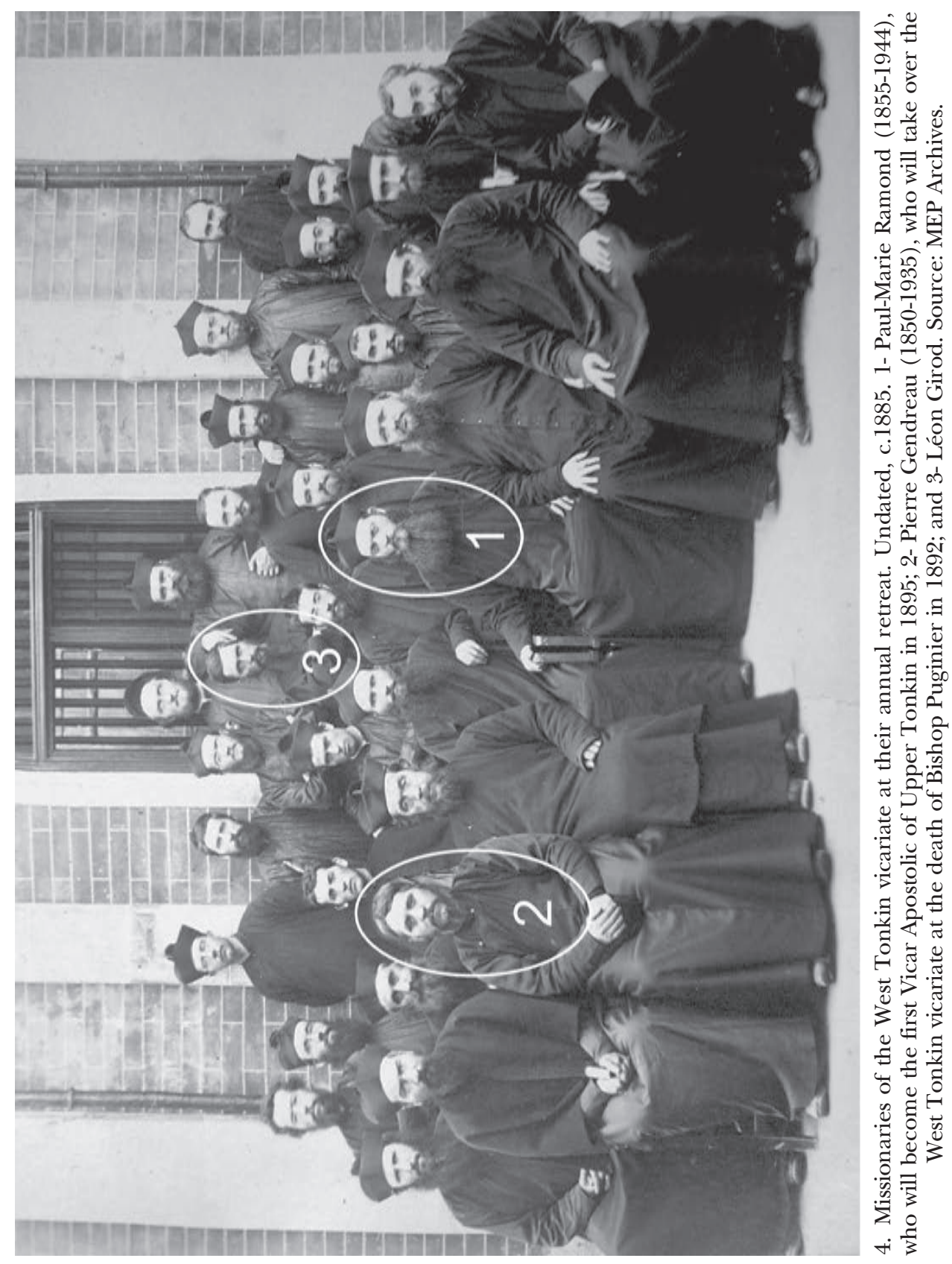




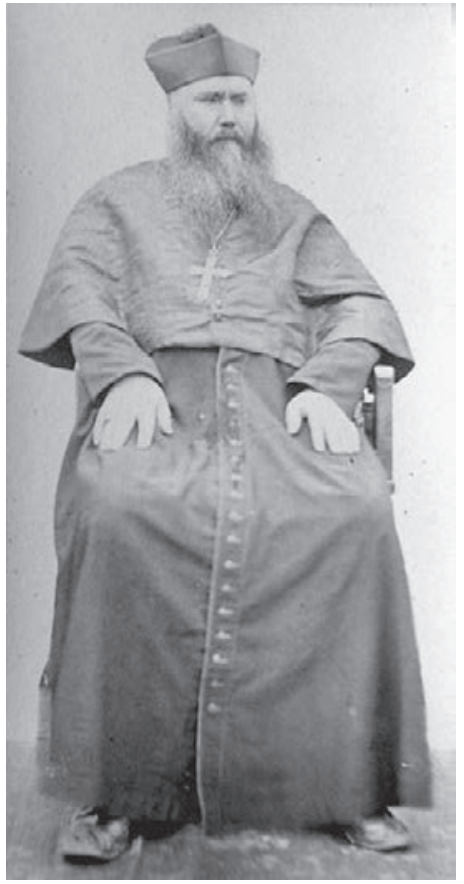

5. Paul François Puginier (18351892), Évêque de Mauricastre in partibus, Vicar Apostolic of West Tonkin from 1868 until his death. Undated, c. 1890, probably in Hanoi. Source: MEP Archives.

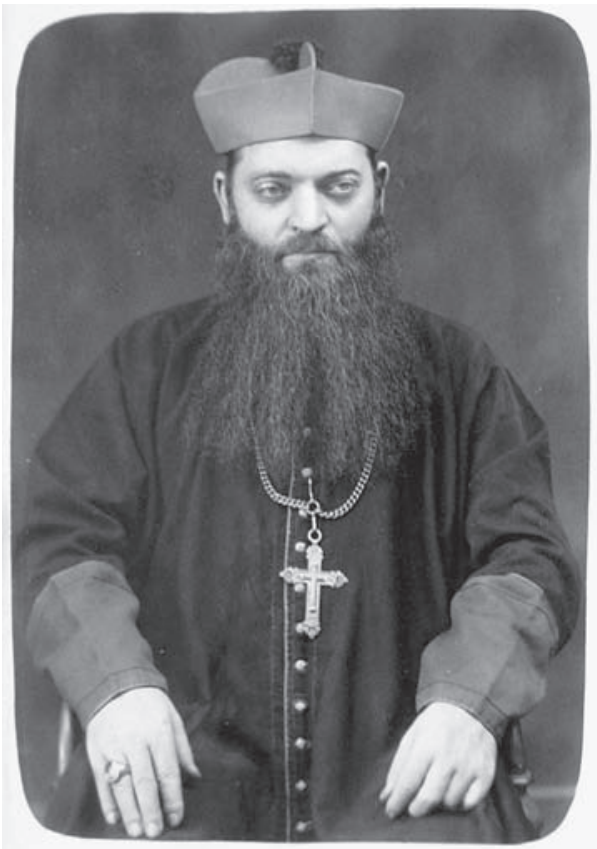

6. 1895 - P.-M. Ramond photographed in Hanoi when he was ordained Évêque de Linoë in partibus. Vicar Apostolic of Upper Tonkin from 1895 to his resignation in 1938. Source: MEP Archives. 


\section{Glat}

du toisions du Gonkin Gecidental et de Heaut. Qornkin

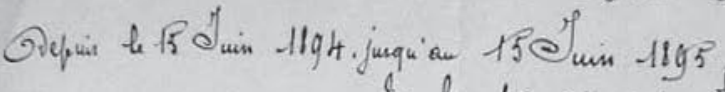

G) putionnaine .

हo

Otendue de ta llowion.

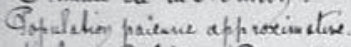

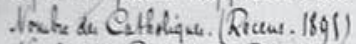

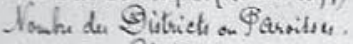

Emrituata.

eqlice as chapelles. Etminaires.

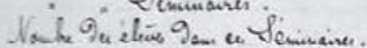

treok da Patichute.

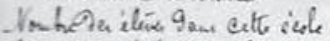

Gisition falk, gen f'ence

- Nombe des siver chisticen

J mabeder clive gau ces sicole.

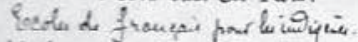

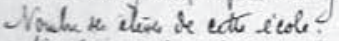

louk des Ouphelinats.

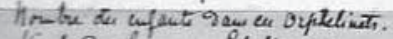

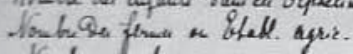

Torhe dee thisiomanie enroficion.

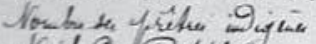

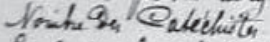

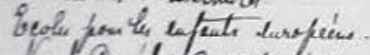

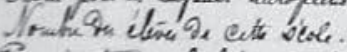

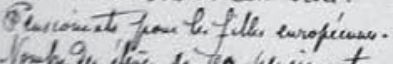

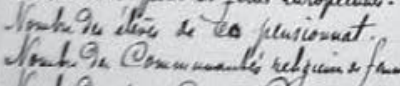

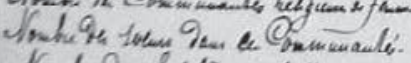

touts is heftion a froins.

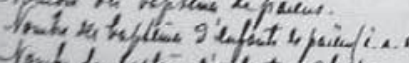

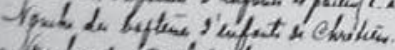

Mouty da Oafuinetion.

reval. ba Osteferion.

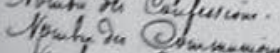

Vosh revaigh. Sintigu.

Vowhe des by ficios. Ouction.

thets in trarisgen.

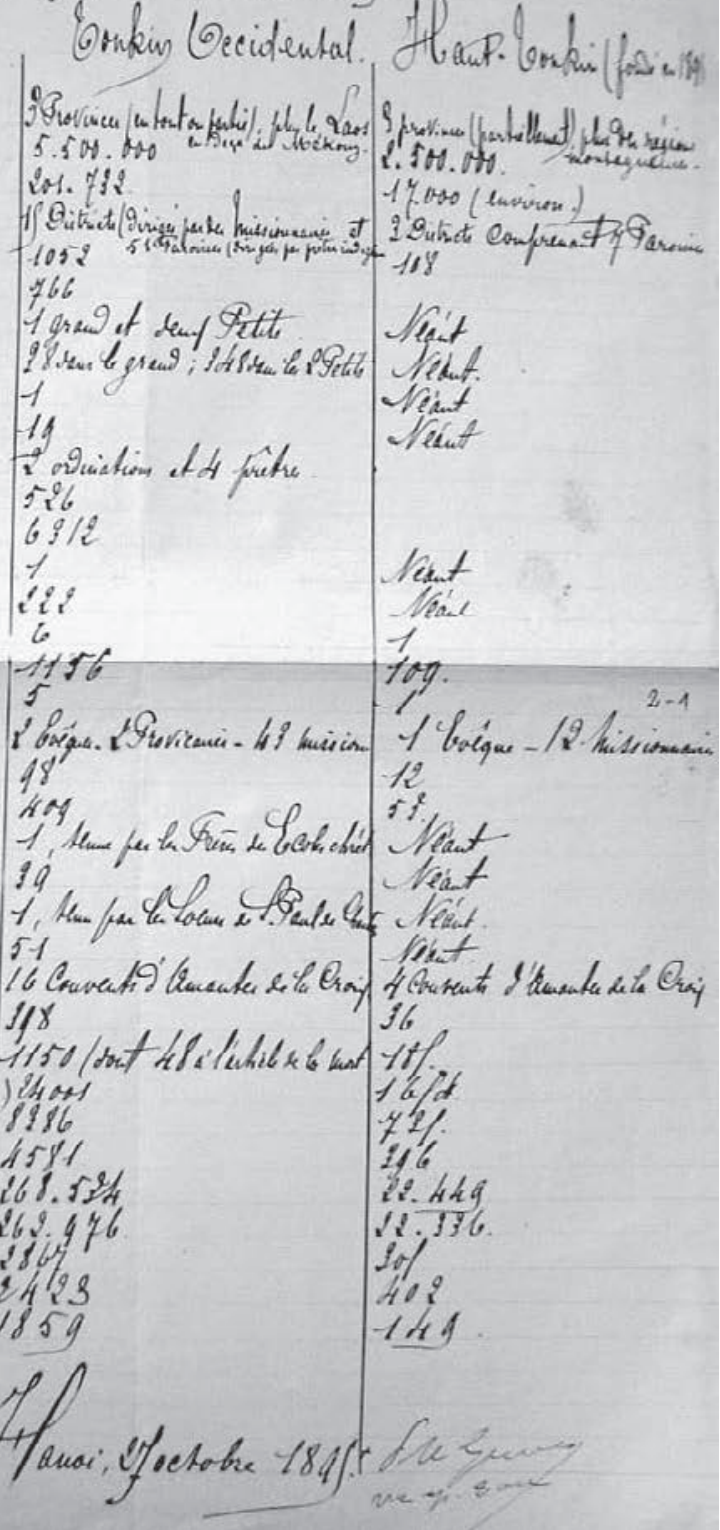

7. "État des Missions du Tonkin Occidental et du Haut-Tonkin depuis le 15 juin 1894 jusqu'au 15 juin 1895" - Statistics on the state of the West and Upper Tonkin vicariates, dated October 27, 1895. These two vicariates are listed here as having respectively 2 Bishops for 43 missionaries, and 1 Bishop for 12 missionaries. This list was part of the first annual comptes-rendus from the newly established Upper Tonkin.

Source: MEP Archives. 


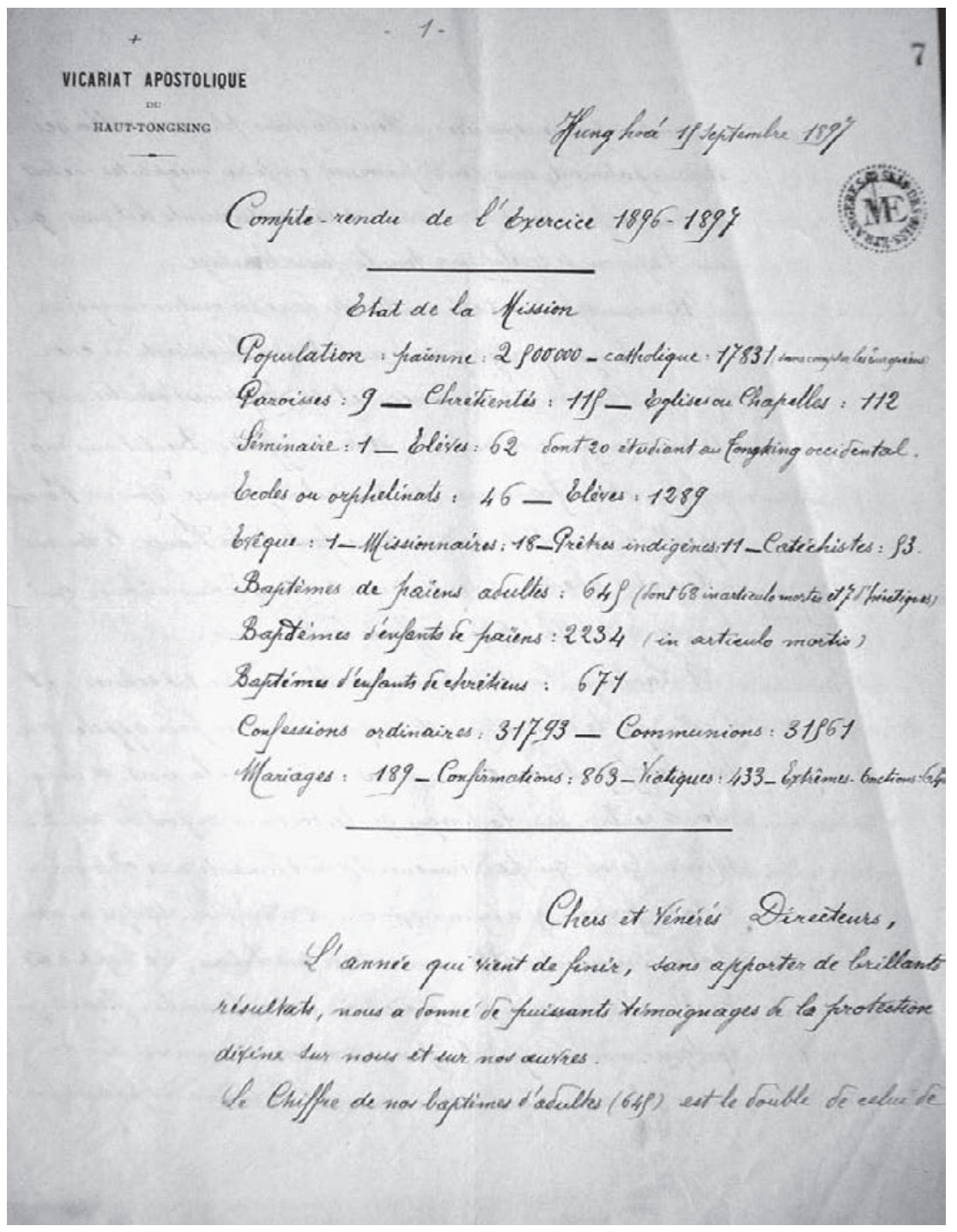

8. “Compte-rendu de l'exercice 1896-1897." Annual report from the Upper Tonkin vicariate written by Bishop Ramond, dated September 11, 1897. The Bishop reports for that year 18 missionaries and 11 native priests for a population of 2.9 million. Source: MEP Archives. 

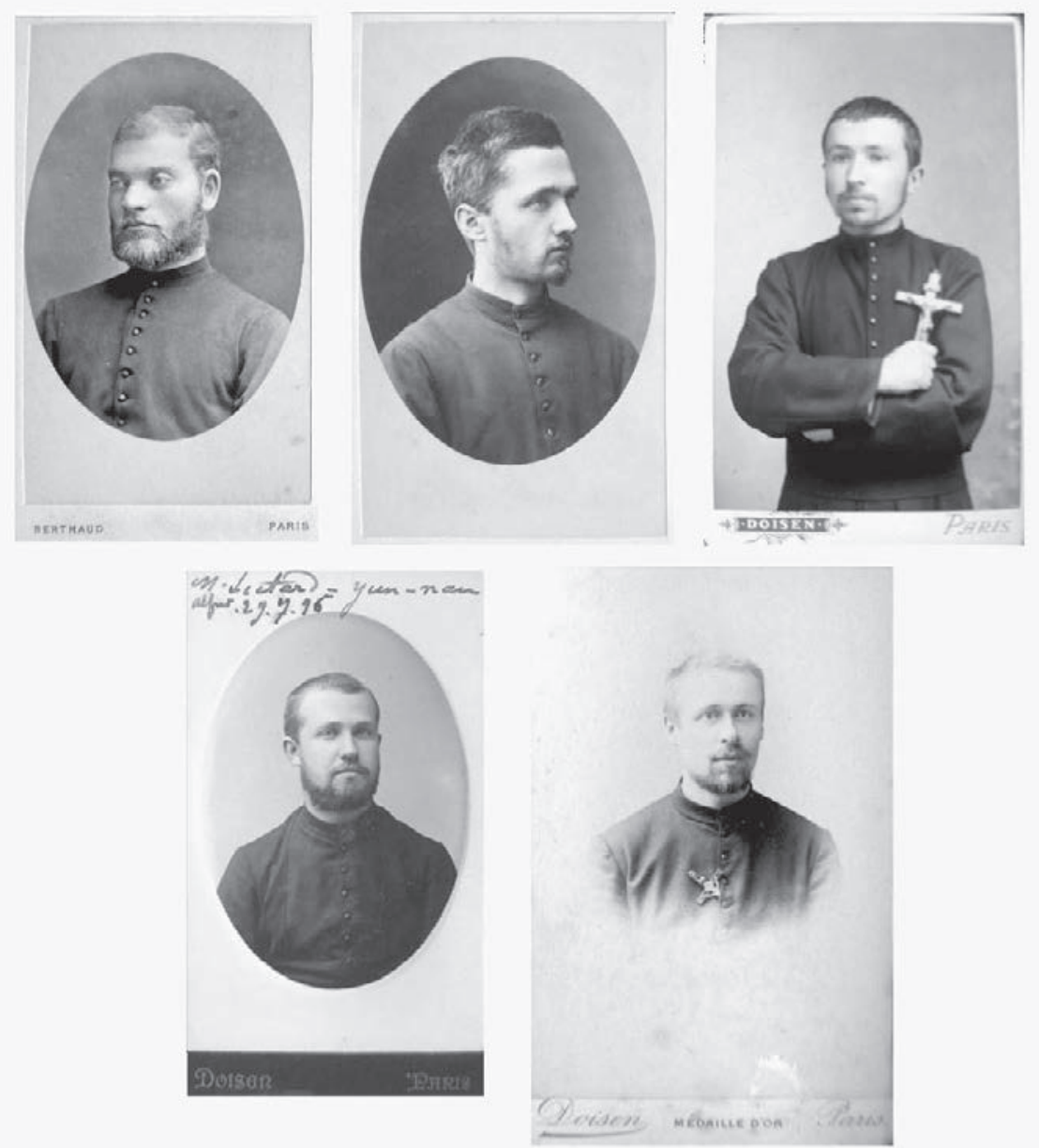

9. Paul-Marie Ramond (1881), Léon Girod (1879), Antoine Bourlet (1898), Alfred Liétard (1896), and François-Marie Savina (1901) each photographed in Paris just prior to their departure to Asia. Source: MEP Archives. 


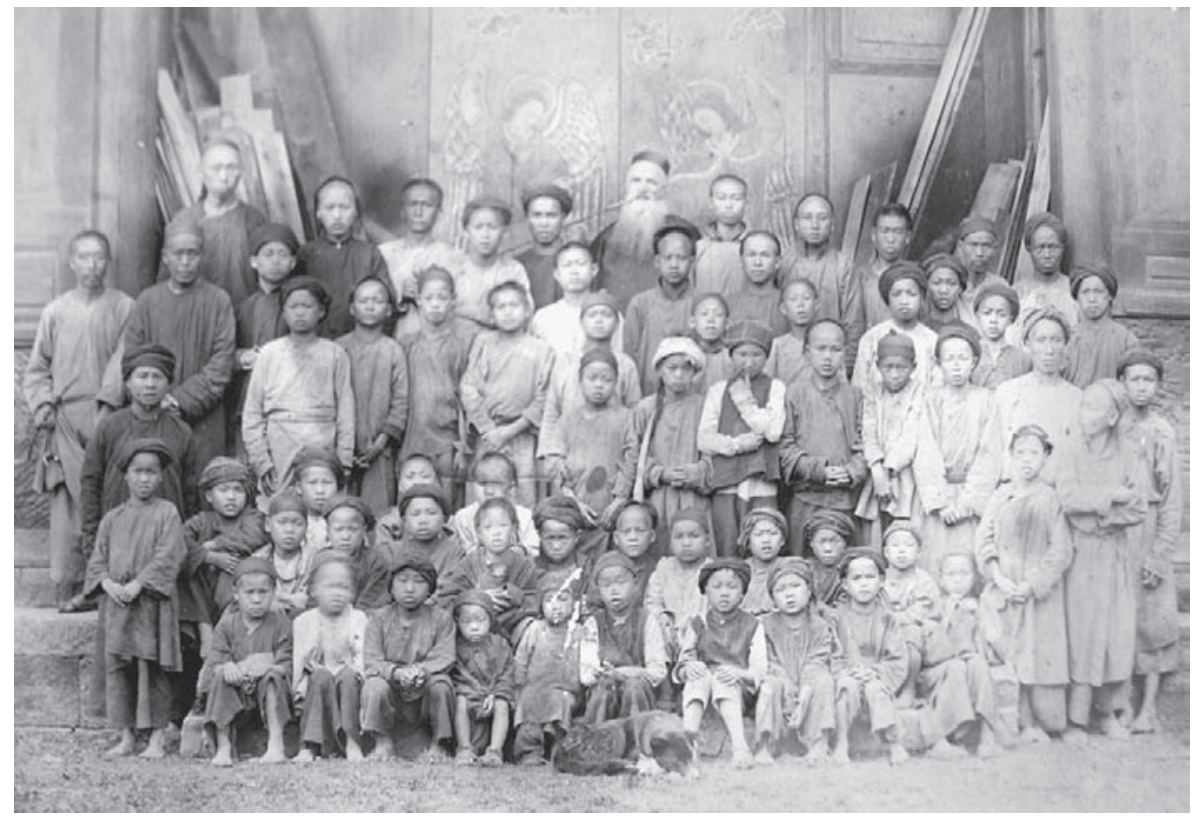

10. Father Aloys Schotter (1857-1924), top centre in the back row, smoking a long pipe, in his boys' school of Lanlong, western Guizhou. This picture was taken the year of his death. Fung Yut Hin, photographer. Source: MEP archives.

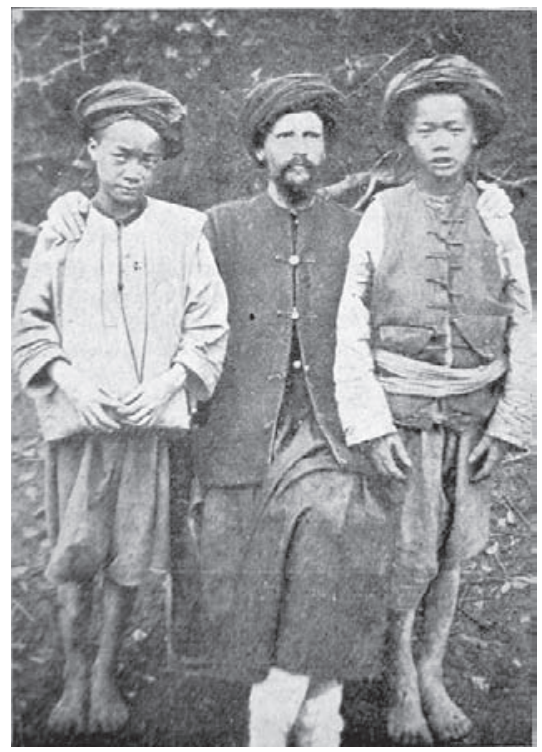

11. Paul Vial (1855-1917) dressed as a Lolo, with two Lolo converts. This undated picture appeared on the cover of his 1905 book, Yun-Nan Nadokouseu grouping articles previously published in Annales de la Société des Missions Étrangères. 


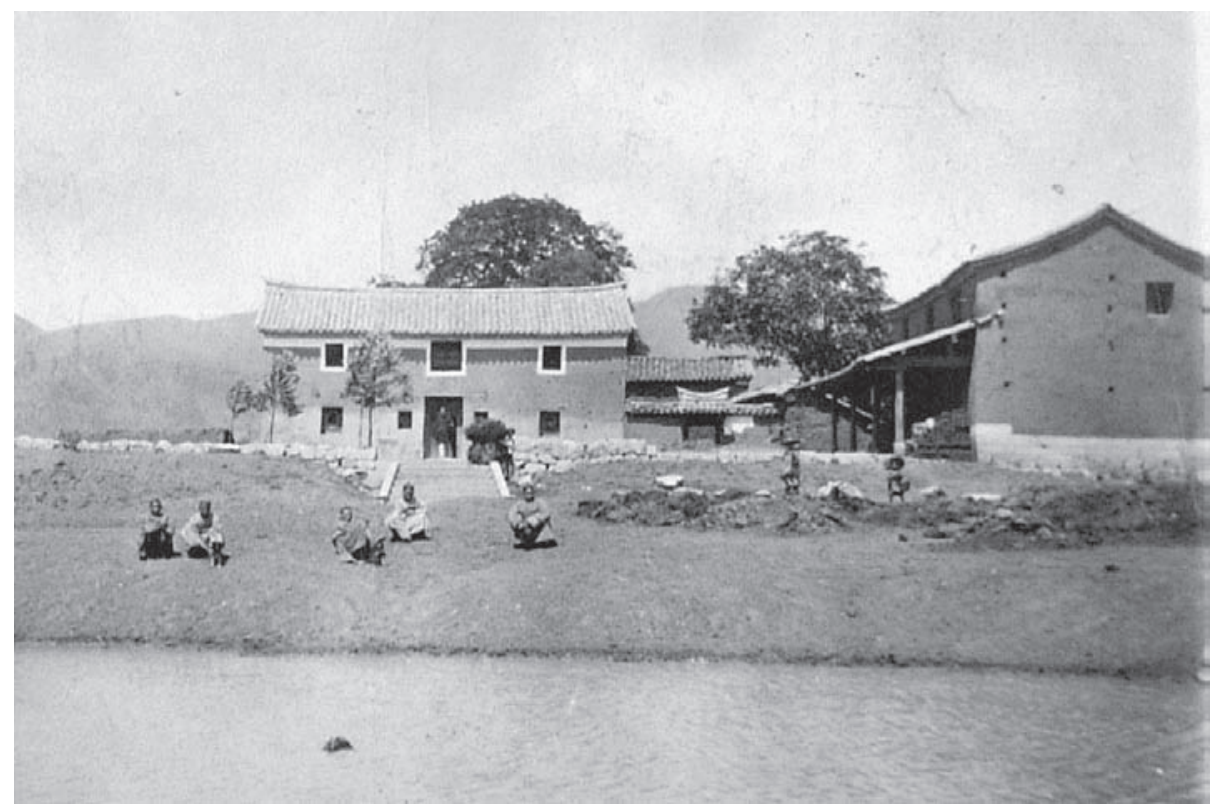

12. 1895 - Lou-mei-y, eastern Yunnan. Residence of Father Paul Vial, possibly his 'château' of St-Paul-la-Tremblaye. Photograph (fragment) by Paul Vial. Source: MEP Archives.

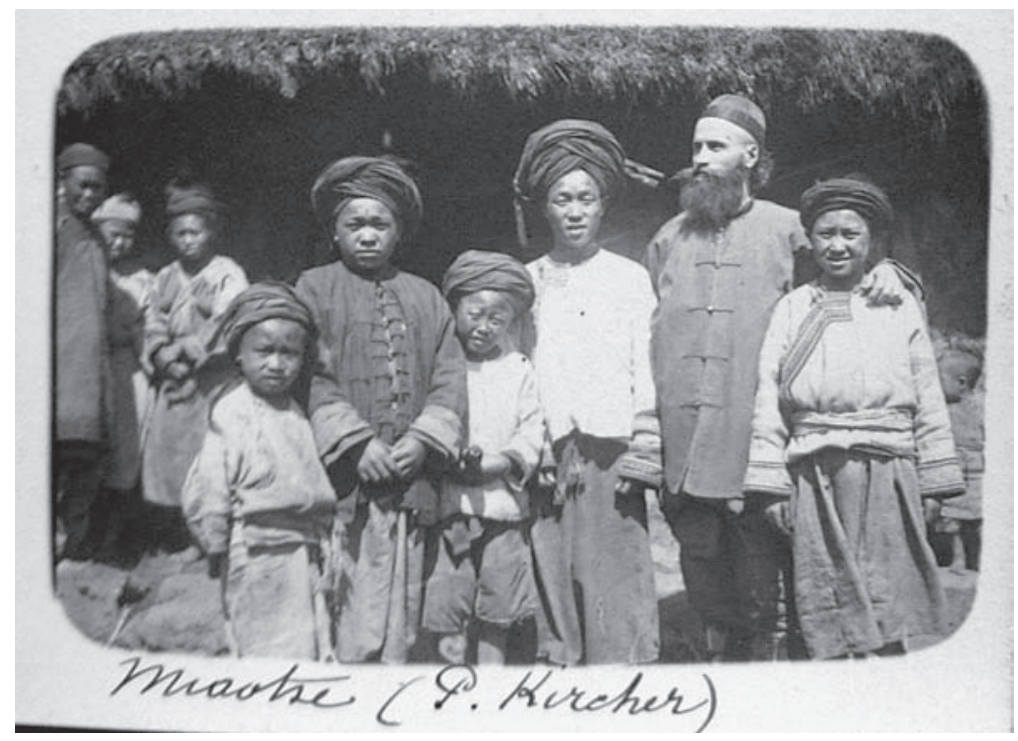

13. Father André Kircher (1863-1922) in Chinese attire among Miao (Miaotse) converts in Yunnan, photographed by his friend Paul Vial, undated. Source: MEP Archives. 


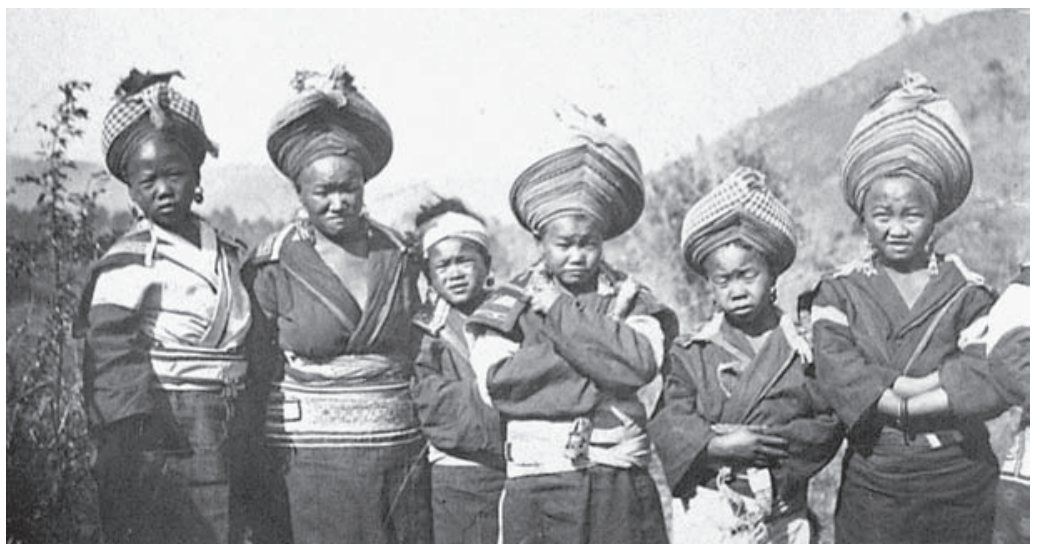

14. White Miao women in eastern Yunnan. Undated photograph by Paul Vial. Source: MEP Archives.

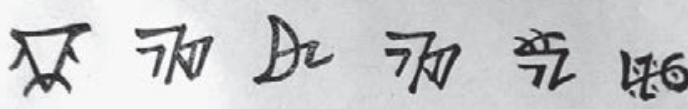 \\ DICTIONNAIRE \\ FRANÇAIS-LOLO,}

DIALECTE GNI 任.

TRIBU SITUEE DANS LES SOUS-PREFECTURES

$\mathrm{DE}$

Lóu nân tcheōu 路值州

Lðu leâng tcheōu 陸淙州

Koùang-si tcheōu 度西州

PROVINCE DU YUNNAN

PAB

PAUL VIAL

Missionnaike Arostóligue au Yunnas.

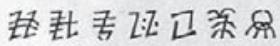

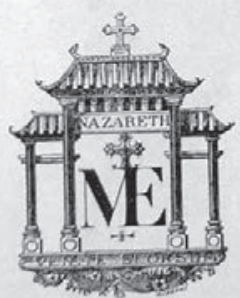

HONGKONG

IMPrIMERIE DE IA SOCIÉtÉ DES Missions-ETrANgères

1909

15. Paul Vial's “Dictionnaire Français-Lolo”, 1909. 


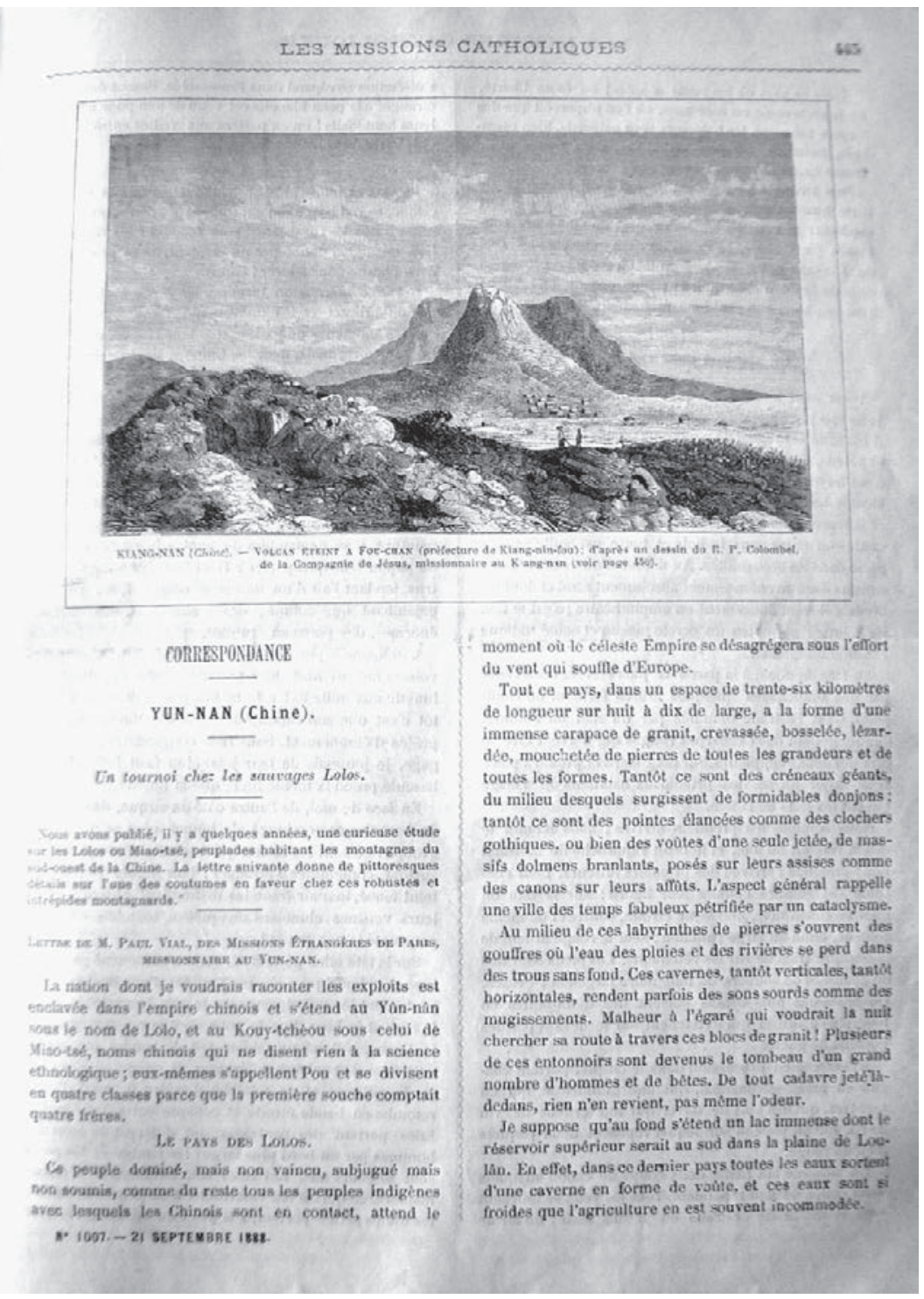

16. First page of an article on the Lolo of Yunnan by Paul Vial in Les Missions Catholiques, 21 September, 1888. The picture is also from China but is not connected with the article. 


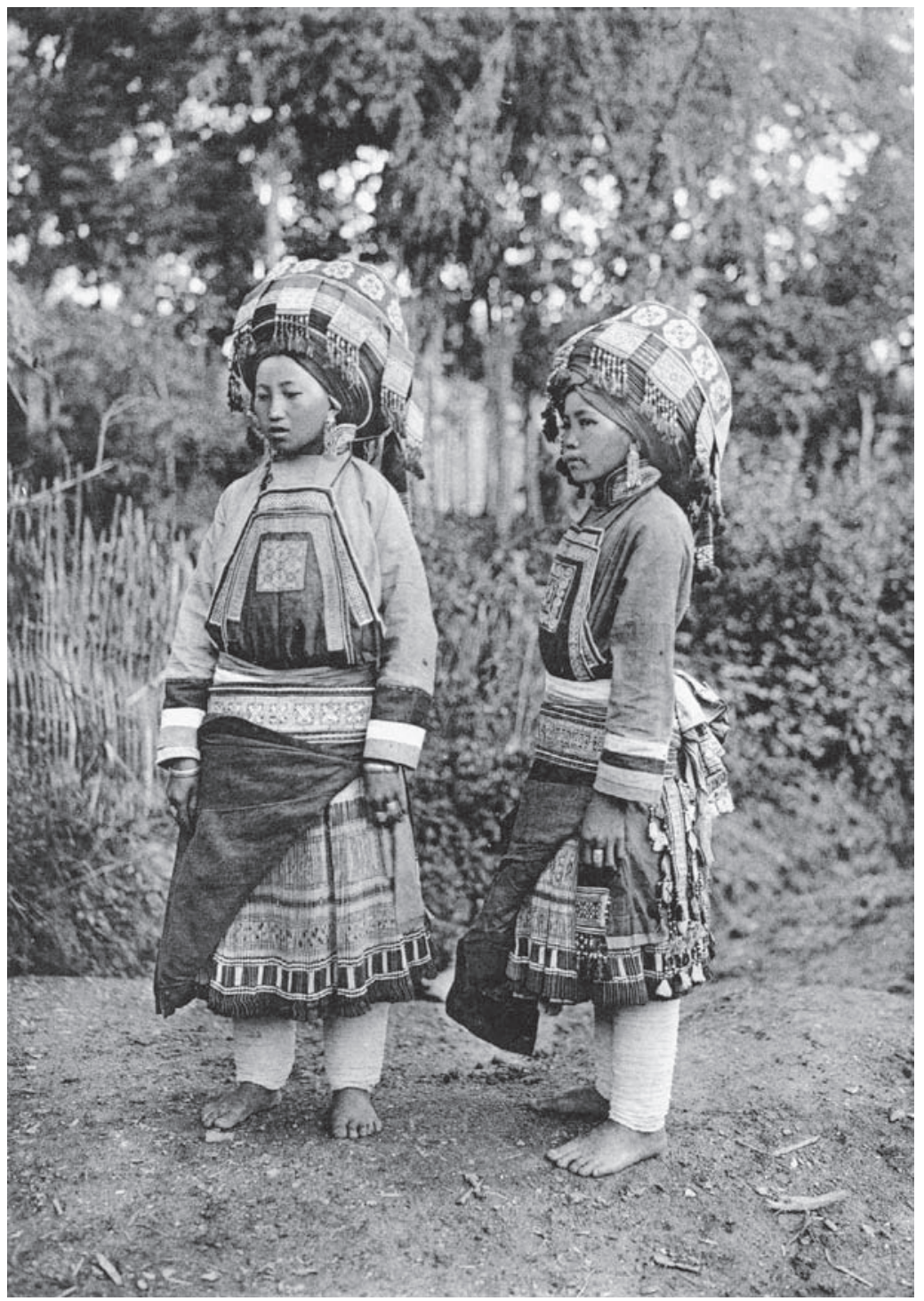

17. Peu-méo (Hmong) girls in upland Tonkin in the late $1910 \mathrm{~s}$, from Maurice Abadie's Les races du Haut Tonkin de Phong Tho à Lang-Son, 1924. Photographer unknown. 


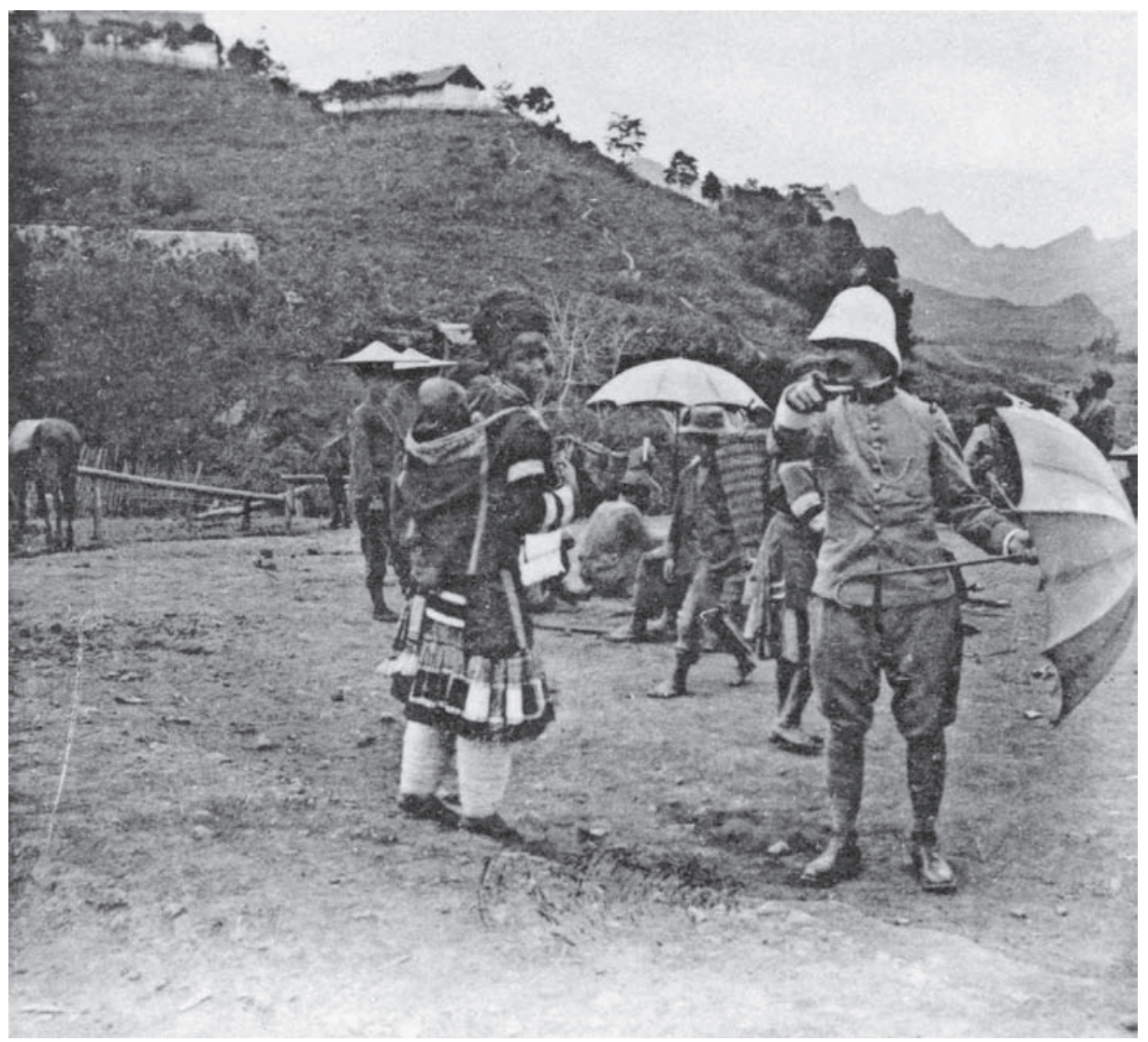

18. French soldier interacting with a Hoa-méo (Hmong) woman, Pa-Kha (today Bac Ha), northern Tonkin, late 1910s. Photographer unknown. Source: Abadie 1924. 


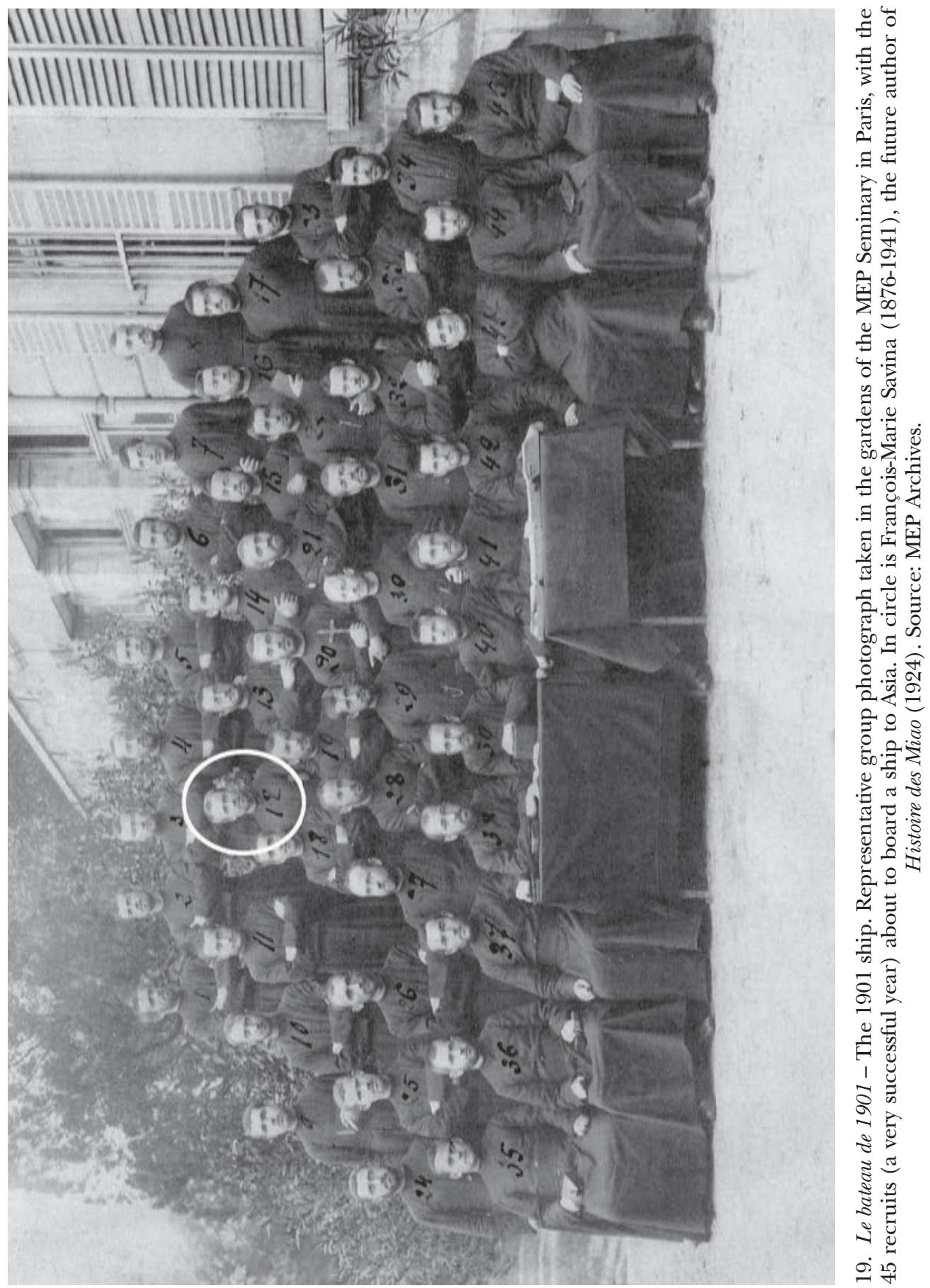




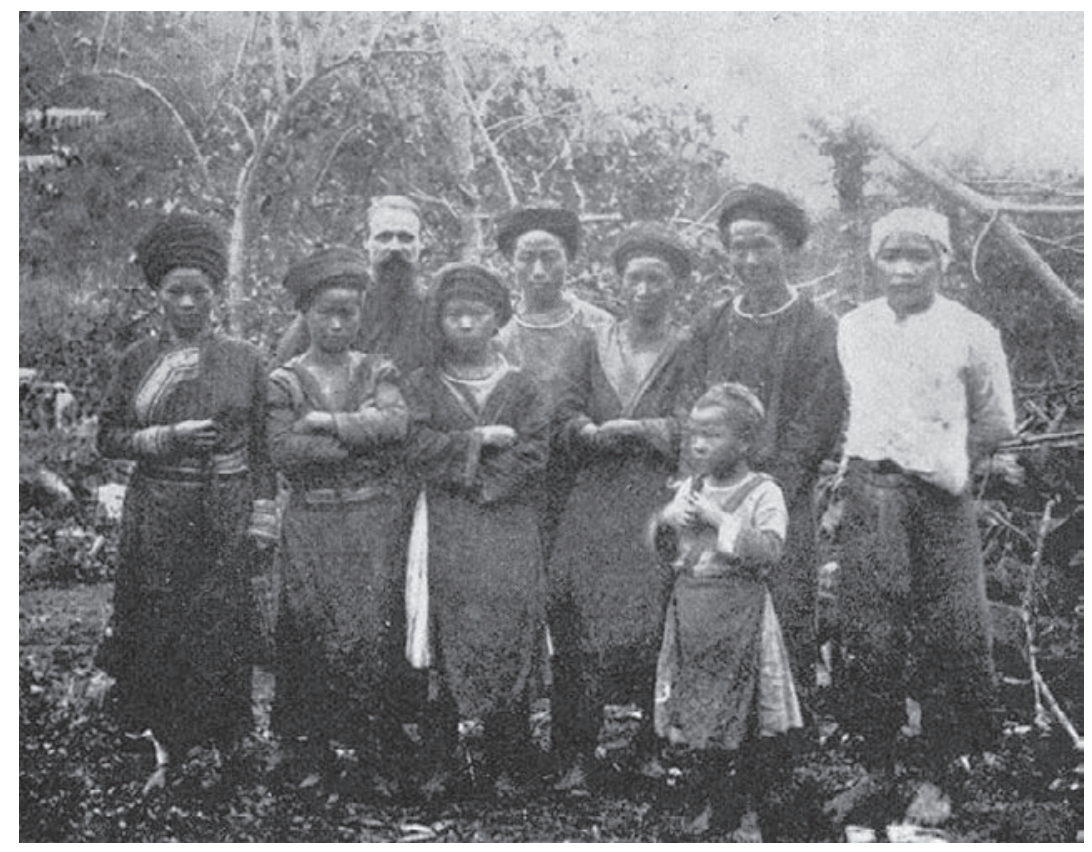

20. Father F.-M. Savina among the Miao (Méo, Hmong) in Tonkin. Undated, c.1920. Source: Savina 1924.

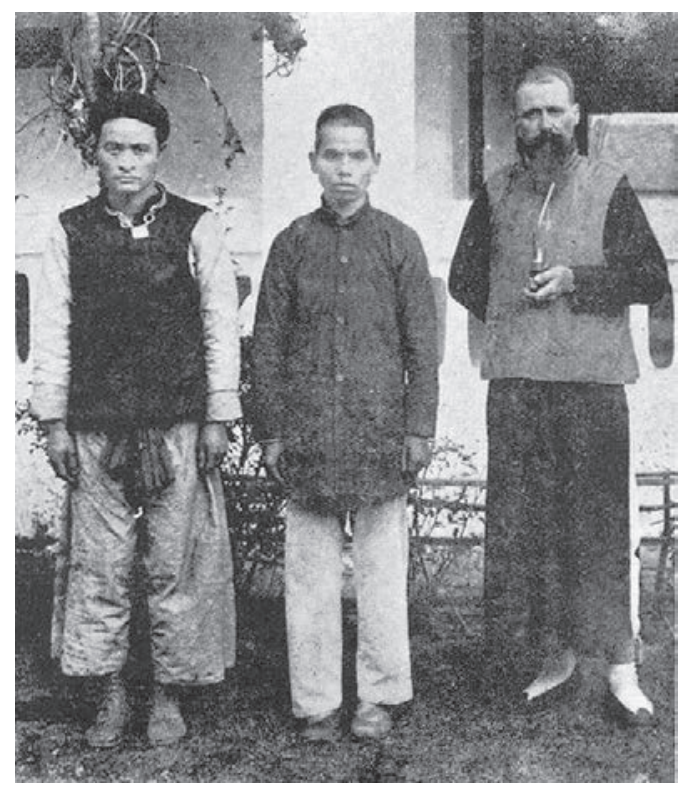

21. 1920 - F.-M. Savina at age 44 in Xieng-Khouang (Tranninh), northeast Laos, during the two years he was detached to the colonial troops sent to tame a Méo rebellion. Savina stands with his Nung personal assistant (centre) and a Miao leader (left). Source: Savina 1924. 


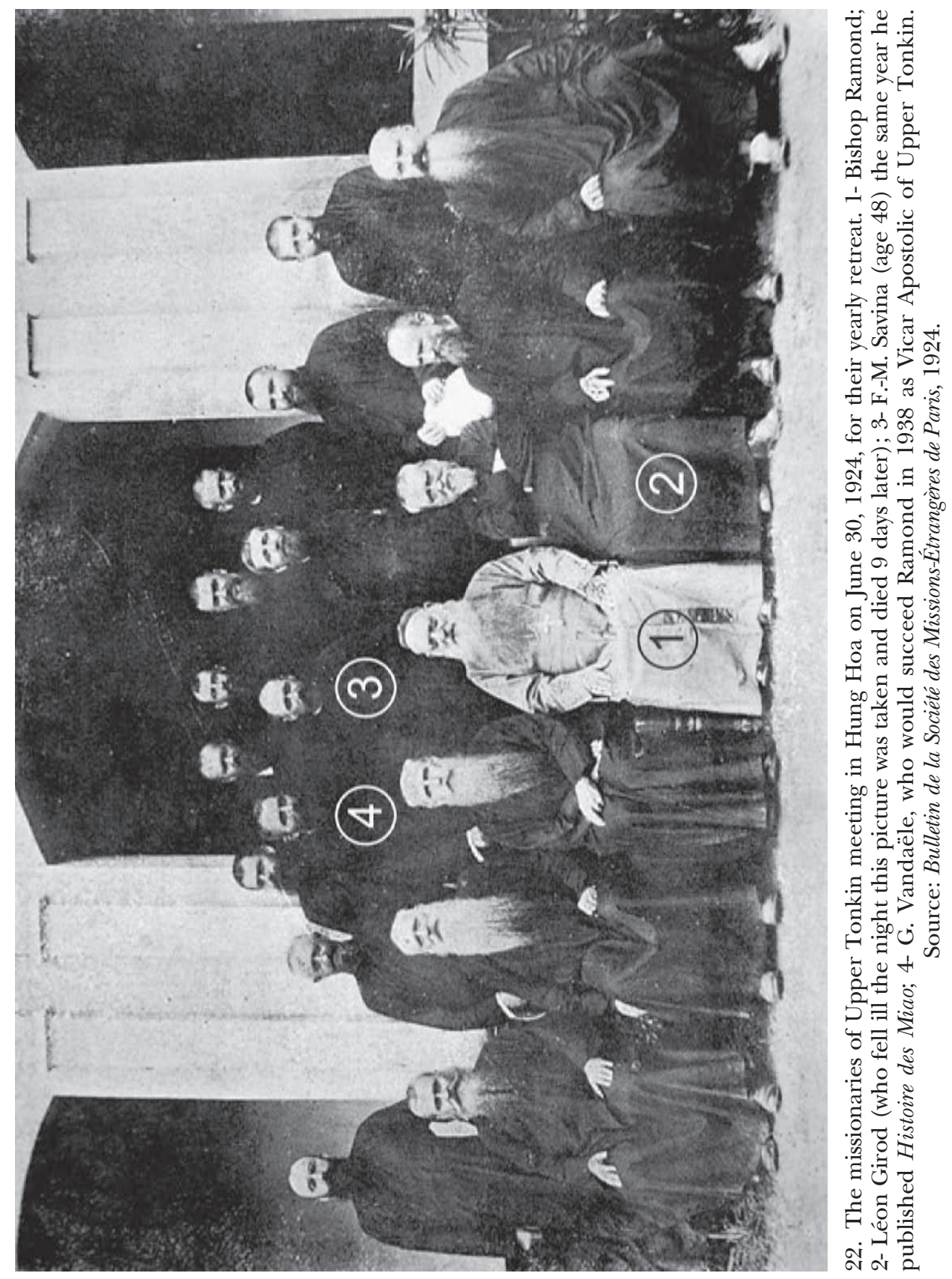




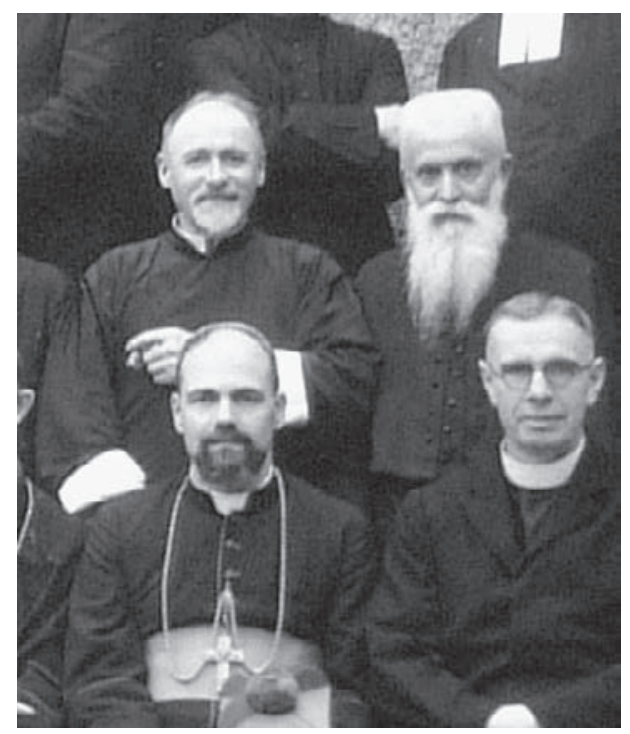

23. F.-M. Savina (top left), at age 58, with colleagues in Hong Kong, 1934 (fragment). Just back from a year in France, Savina was starting a 5 year stay in Hong Kong to put together his Guide linguistique de l'Indochine française (1939). Source: MEP Archives.

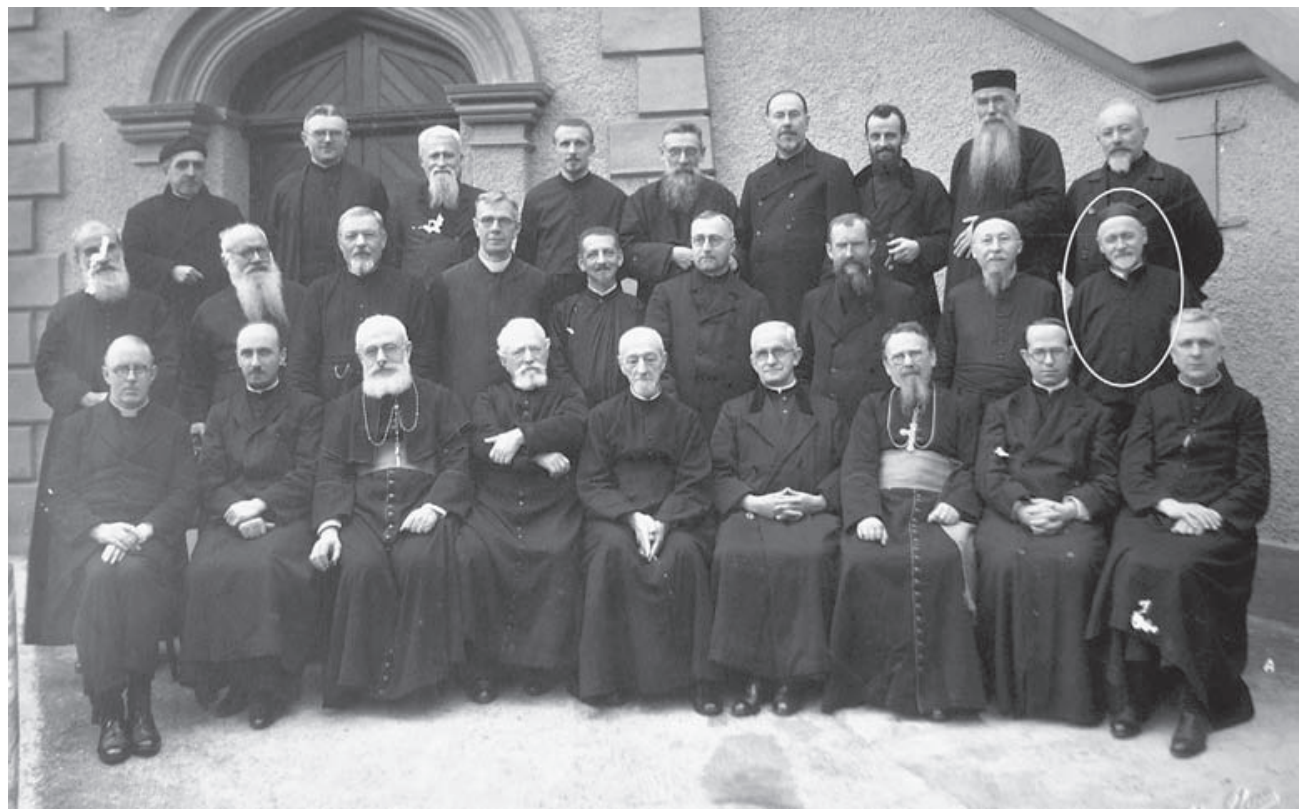

24. 1938 - F.M. Savina (circled) still at the MEP house in Hong Kong writing his multilingual dictionary. Source: MEP Archives. 


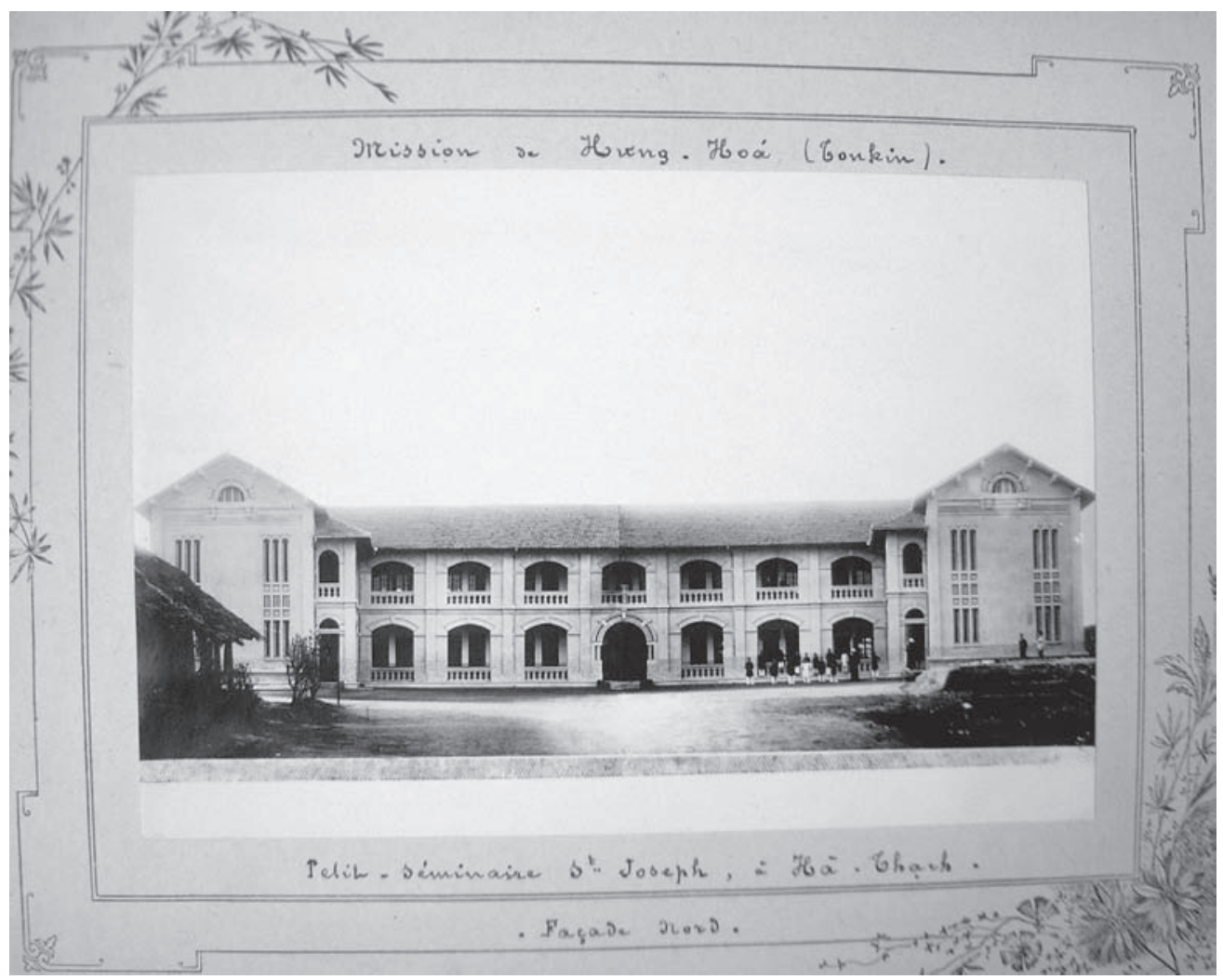

25. North face of the MEP St-Joseph Minor Seminary in Ha-thach, Upper Tonkin vicariate. The seminary was destroyed, along with the buildings of the vicariate's see in Hung Hoa, during the First Indochina War (1945-1954). Undated. Source: MEP Archives. 


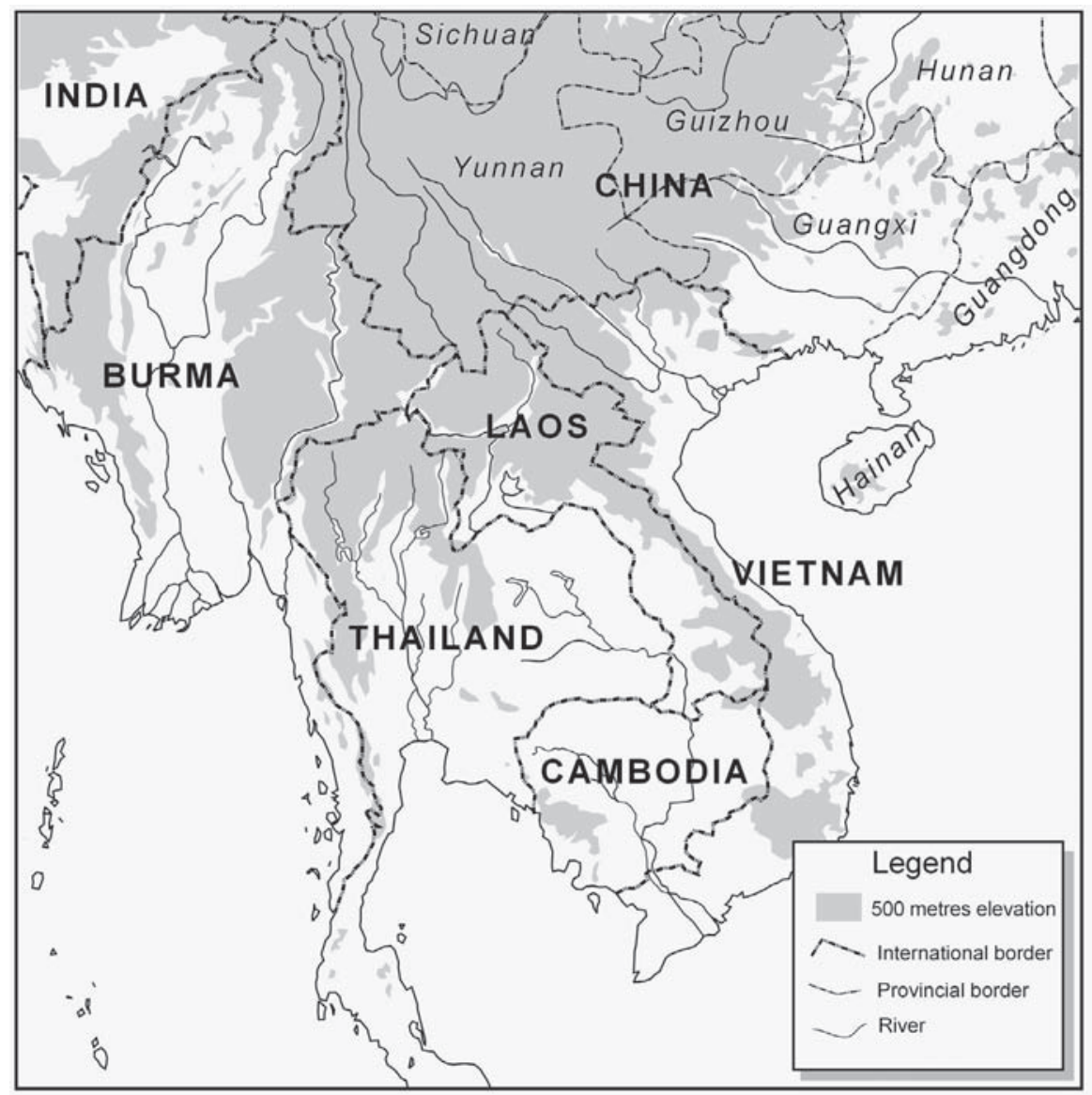

Map 1 - General area of interest 


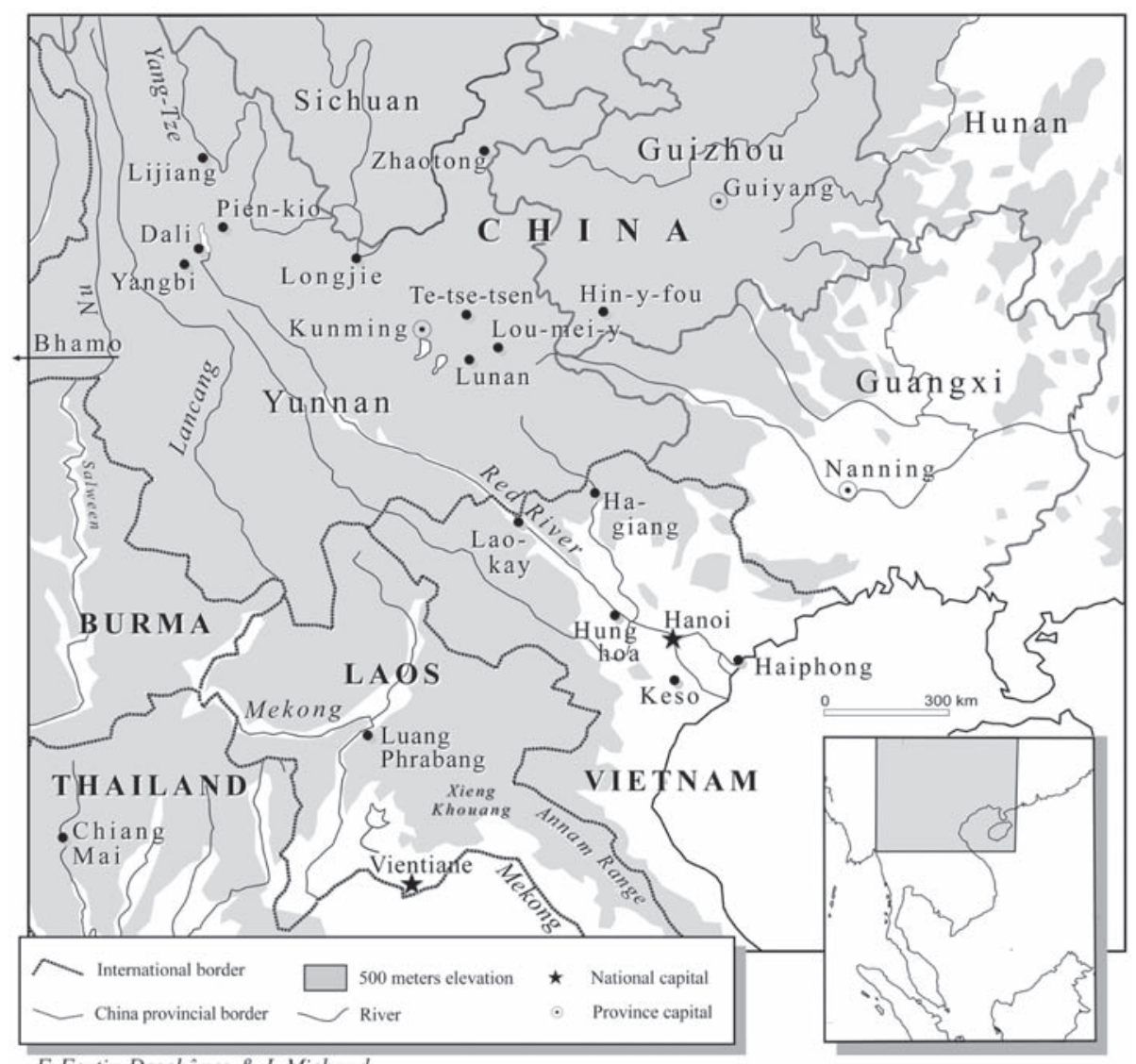

F. Fortin-Deschênes \& J. Michaud

Map 2 - Principal locations today 


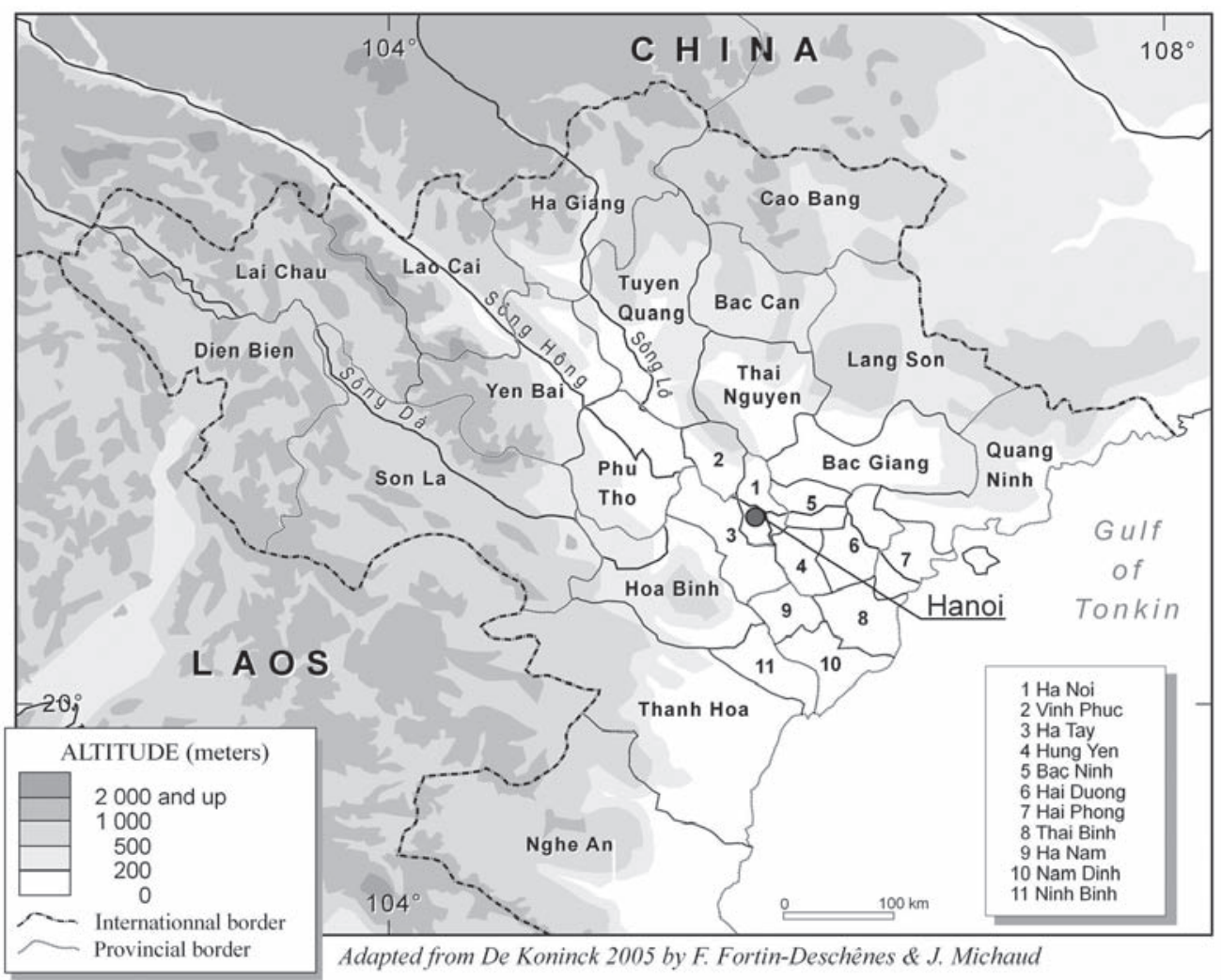

Map 3 - Northern Vietnam - Provinces and topography, 2006 


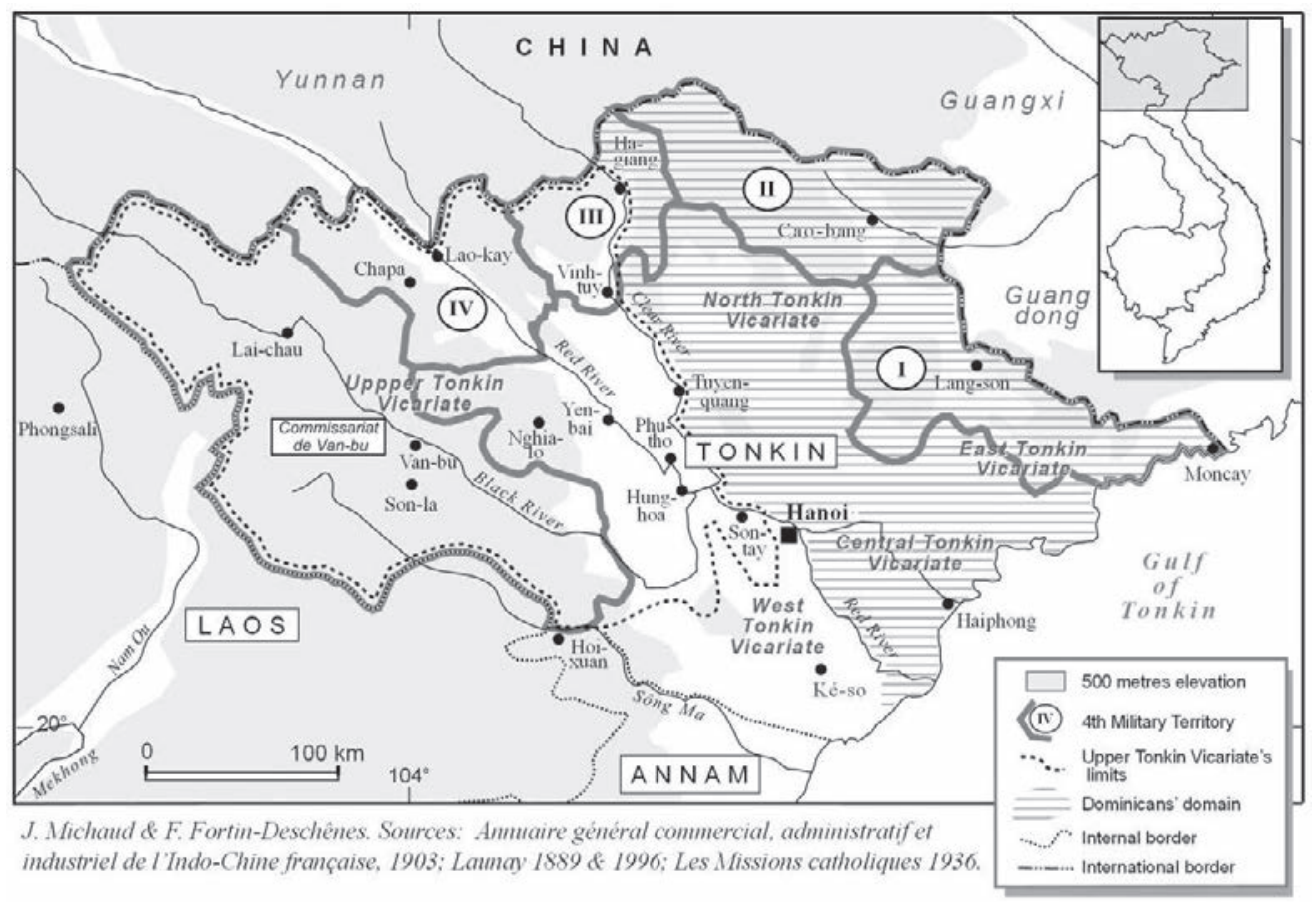

Map 4 - Tonkin: Military Territories (1903) and Vicariates (1896) 


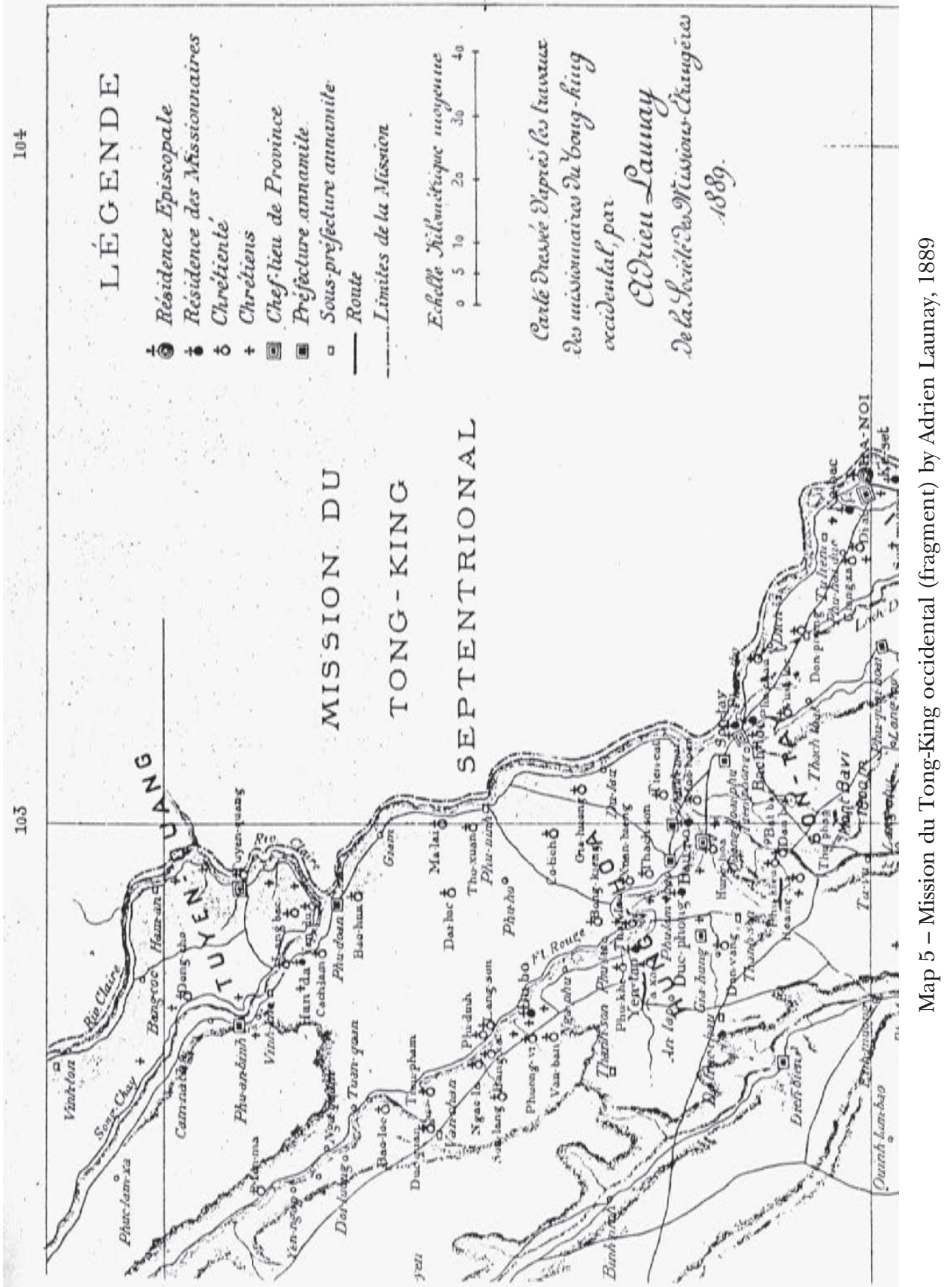




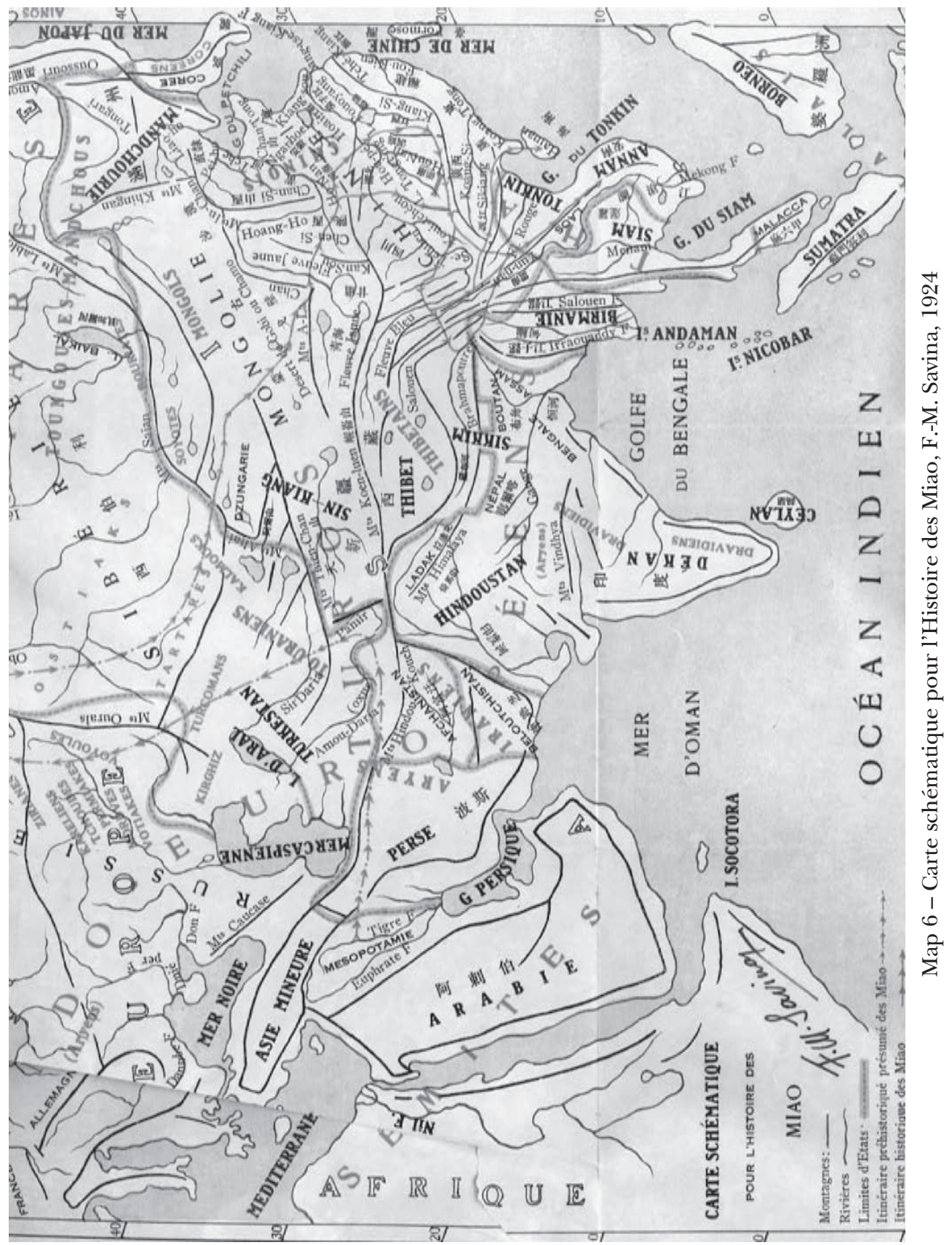




\section{INDEX}

Abadie, Maurice, 14, 15, 219

Abenaki, 45, 52

agriculture, 34, 77, 101

Algonkin, 52

Americas, 44, 50

ancestor worship, 33

Anglican, 148, 219

Animism, 33, 56, 57

Annales de la Société des Missions Étrangères, 163, 215

Annam, 22, 31, 88, 92, 113, 222

Annam Range, 20

Annamite (Vietnamese), 27, 31, 97, 132, $136,167,222$

An-tây prefecture, 20

anthropology, ix, 3, 5-11, 13, 38, 43, 50, 59-63, 81, 102, 109, 134, 155, 187, 203, 207, 216, 224: economic anthropology, 147

Anthropos, 5, 8, 141-144, 150-152, 154, 157, 158, 202, 206, 214, 218, 222

anticlerical critics, 133, 223

anti-French resistance, 113

Antonini, Antoine, 120, 121

apostolic mission, 11, 93, 202

Asian missions, 93

Asong, 108

Assam, 110

Austro-Asiatic family, 31, 33

Austronesian, 19, 35

Ayutthaya, 90

Babel, 193, 198, 204

Bac Thành, 23

Bách Loc, parish of 119

Bangkok, 105

barbarians, 148, 195, 226, 228

Bau-no, parish of, 119

Bear nation, 55

Bessière, Amans, 119

Bhamo, 159

Bible, 56, 194, 201, 202, 220

Black River (Sông Đà), 20, 22, 27, 32, 106, 108, 110, 117, 119-120, 125

Black Tai, 108

Blondel, Auguste, 120

Boas, Franz, 10, 205

Bonifacy, Auguste, 15, 82, 158, 208
Bonnard, Jean-Louis, 221

Borie, Pierre, xiii, 221

Boucher, Pierre, 52

Bourlet, Antoine, xiv, 16, 142-145, 214

Boxer Rebellion, 150, 162

Bridgman, E.C., 148, 206

Brisson, Théodule, 141

British anthropology, 10

Brossier, Eugène, 119

Broumton, C. 206

Brûlé, Étienne, 52

Bulletin de la Société des Missions-Étrangères de Paris, 139, 223

Bulletin de l'École française d'Extrême-Orient (BEFEO), 28, 154, 173, 184

Burma, 22, 32, 33, 77, 103, 104, 106, $110,159,218$

Cadière, Léopold, 210, 222, 223

Callet, François, 210

Canada, 17, 43, 45, 46, 48-51, 53, 54, 58, 59, 89, 213

Cao Bang, 28, 32, 36, 174, 175, 181

Cao Huy Thuan, 112

Cardinal de Richelieu, 50

Cardinal Mazarin, 45

Cartier, Jacques, 45

Catholic Church, 68, 81, 89, 229

Catholic doctrine, 223

Catholic mission to Laos, 114

Catholic mission(s), ix, 17, 44, 80, 89, 119, 122, 153, 166, 229

Catholic missionary expansion, 89

Catholic missionary, 13, 16, 17, 49, $65,67,68,74,78-80,88,89,141$, 231

Catholic missionaries, 3, 11, 13, 14, 39, 48, 64, 70, 73, 87, 93, 148, 227

Central Highlands, 36, 37, 98, 103, 104, 122

Cham, 35, 38

Chapa (Sapa), 77, 125, 127, 173, 174, 176, 179-182

Chatellier, Pierre, 119

châu (Sub-prefectures), 20, 21, 24

Chavannes, Alexandre, 158, 225

Chevreul, 90

China, xiv, 11, 14, 17, 19-22, 26, 27, 
31-34, 37, 38, 44, 89, 93, 94, 95, $100,102,103,106,123,130,135$, $142,145,148,149-151,153,159$, $169,176,177,184,189,190,194$, 202, 219, 233

China Inland Mission, 219

Chinese border (Yunnan), 14, 19, 28, $32,115,116,120,123,125$

Chinese highlands, 161

Chinese historical accounts, 148

Chinese Republican troops, 173

Chinese source(s), 158, 194, 195

Chotard, Julien, 119

Christian community, 89, 119

Christian faith, 90, 91, 138, 222, 224

Christian missionary(ries), 7, 8, 10, 98, 141, 206

Christianisation, 217

Christianity, 12, 89

civilization, notion of, 50, 79, 228

civilizing mission, 10, 228

Glear River (Sông Lô, Rivière Claire), 16, 22, 32, 94, 116, 119, 120, 124, 170, 174, 175, 180, 208

Clifford, James, 3, 9, 83

Cochinchina, 38, 89, 90, 92, 222

Colbert, Jean-Baptiste, 45

Cold War, 61

colonial authorities, 47, 74, 76, 77, 114, 125, 127, 169, 171, 180, 226

colonial ethnic classification, 30

colonial ethnography, 4

colonial history, ix, 13, 203

colonial missionary(ies), 6, 11, 66, 217

colonial politics, 73,110

Colquhoun, Archibald, 77, 109, 159, 218

Commune uprising (Paris), 229

communist ethnologists, 37

Communist Party, 35

Compagnie du Saint-Sacrement, 89

comptes-rendus, xiii, 76, 95, 118, 134, 135, $137,138,142,160,170-172,174$, $175,177,180,213,214,218,220$

Comte, Auguste, 59, 205, 223

Condominas, Georges, 210

Congregatio de Propaganda Fide, 16, 89

Conklin, Aline, 228, 229

conquest, 14, 30, 76, 88, 101, 112, 114

contextual value, 140

conversion, 44, 46, 52, 88, 91, 95, 97, $121,134,138,139,140,145,165$, 171

Cordier, Henri, 157, 158
Cornay, Jean-Charles, 118, 221

cosmogony, 144, 193, 201

Cothonay, Bertrand, 181

Coton, Pierre, 54

Crawford, T.P., 148

Cree, 52

Cua-bang, 89

cultural expansionism, 160

cultural relativism, 26, 79

Cupet, Pierre-Paul (Captain), 104

D'Abrigeon, Pierre, 119, 120, 135, 141, 171

D'Ollone Mission, 77

D’Ollone, Henri, 158, 189

d'Orléans, Henri-Philippe-Marie

(Prince), 110, 158

Dao (see Man)

Darwinism, 69

de Brébeuf, Jean, 48, 51, 54, 55, 219

de Certeau, Michel, 50

de Champlain, Samuel, 45, 52

de Charlevoix, Pierre, 48, 51, 216

de Coligny, Gaspard, 44

de Cooman, Alexandre, 120

De Gérando, Joseph-Marie, 225

de Guébriant, Jean-Baptiste, 77

de Lanessan, Antoine, 113, 114

de la Selle, Marie (Viscountess), 161

de Las Casas, Bartolomeo, 216, 231

de Léry, Jean, 216

de Montmorency de Laval, François, 89

de Quatrefages de Bréau, Armand, 207, 225

de Rhodes, Alexandre, 88, 89, 97

de Sahagún, Bernardino, 216

de St-Denis, Hervey, 149

decolonisation, 61

Deo family, 106, 116

Deo Van Tri, xiii, 103, 106, 107, 125, 171

descriptive ethnography, 148, 196

Devéria, Gabriel, 102, 149, 158

Deydier, 91

dictionaries, 48, 49, 54, 153-155, 158, 164, 169, 173, 179, 180, 182, 183, 185, 191, 209

Dien Bien Phu (battle, plateau), 108

Diguet, Edouard, 15, 219

diocese, 16, 69, 89, 92

diplomatic mission, 90, 100, 169

Djo-kou-la (village), 151

Đối Mới, the 'economic renovation', 35-37 
Dominicans, 87, 88, 90, 94, 175, 219

Dongdang, 174

Don-hoi (Tonkin), xiii

Doudart de Lagrée, Ernest, 28, 99, 109

Doumer, Paul, 113, 120

Dourisboure, Pierre, 97, 98

Doutreligne, Denis, 223

Dù Ba, parish of, 119

Đuc Phong, parish of, 119

Duchet, Michèle, 50

Duhamel, Emile, 119

Duke of Montmorency, 49

Dupuis, Jean, 14, 24, 28, 99, 114,

Durkheim, Émile, 205, 223

ecclesiastical authorities, 132

École française d'Extrême-Orient (EFEO), 28, $30,82,177$

economic profit, pursuit of, 228

economic systems, 34

Edkins, J., 148, 206

education, 8, 36, 45, 50, 65, 68, 69, 79, $81,97,143,145,158,169,188,208$, 216, 231

elitism, 216

emissary of modernity, 131

Enlightenment, 26, 44, 49, 51, 59, 60, 217, 229

ethnic diversity, 19, 29, 31, 146, 149

ethnocentrism, 8, 65

ethnographic accounts, 216

ethnographic anthologies, 219

ethnographic discourse, 213

ethnographic inquiry, 202, 225

ethnographic literature, 3, 12, 59, 60

ethnographic questionnaires, 227

ethnographic studies, 26, 121

ethnographic writings, 3, 16, 46, 57, 63, $131,144,213$

ethnohistorical issue, 194

ethnological academic standards, 145

ethnological intention, 213, 214

ethnological research, 37

ethnological sources, 207

ethnology, 12, 59, 60, 134, 142, 145, 167, 192, 193, 196, 205, 222, 223, 337

ethnonym, 29-32, 164, 195

Eurocentric, 187, 195

European colonization, 6

Evans-Pritchard, E.E., 11, 59

evolutionism, 26, 60, 50, 60, 138, 202, 221
Fanon, Franz, 61

Ferry, Jules, 114

field research, 226, 227, 224

fieldwork method, 222, 225, 226

Figuet, Paul, 141

Finot, Louis, 82

First Empire (France), 91, 229

First Indochina War, 14, 111, 127

Forest, Alain, 88

Fourth Military Territory, 116, 120

France, 4, 5, 8, 13, 17, 26, 37, 42, 43, 44-46, 48, 49-51, 54, 58-60, 66, 71, 75, 80, 82, 88, 89-93, 95, 98, 101, 102-104, 106, 107, 110, 114, $123,133,139,140,145,158,160$, $162,163,165,169,173,175,180$, $182,213,216,221,224,226,227$, 228-230

Franciscan, 88, 216

Free Masons, 229

French authorities, 27, 46, 101, 114

French Catholic tradition, 68

French colonial administrators, 4

French colonial army, 99

French colonial authority, 106

French colonial tradition, 216

French colonies, 226

French colony of Canada, 213

French Concession (Hanoi), 114

French ethnographer(s), 106, 224, 225

French Indochina, ix, 3, 4, 30, 58, 66, $70,77,83,99,102,106,112,114$, $120,153,210$

French military administration, 117

French professional anthropology, 109

French Protestant, 3, 44, 83, 216

French scientific community, 215

Freppel, Charles, 114

funerary rites, 144

fur trade, 44, 46, 49, 52, 53

Garnier, Francis, 14, 28, 29, 99, 100, $102,109,114,152$

Gauja, Jean, 120

Gendreau, Pierre, xiii, 115, 116, 124, 133

Gendron, François, 52

Geographical Society of Hanoi, 185

Gia Lai, 36

Gia Long (Emperor), 22, 23, 91, 93, 98,

Girod, Léon, xiii, xiv, xv, 98, 118, 119, $136,137,139,140,163,213$

Gni-p'a (lolo subgroup), 160, 163, 164

Government General of Indochina, 177 
Granger, Pierre, 119-121, 137

Great Lakes (North America), 46, 53

Guangxi, 24, 28, 30, 32, 33, 91, 174, 175

Guennou, Jean, 93

Guérard, Jean-Jacques, 98

Guerlach, Jean, 98, 222

Guizhou, 17, 145, 146, 164, 214, 219, 223

habitus, 78, 189, 230, 232

Hà Giang (Ha-giang), 28, 36, 117, 120, $170,172,174,180,182,207$

hagiographies, 112, 221

Hainan island, 177, 178, 184, 185

Haiphong, 182, 208

Haiphong-Yunnansen (Yunnan-Tonkin) railway, 122

Han, 25, 33, 101, 102, 146, 156-161, $165,189,190,194,195$

Hanoi, 14, 19, 20, 30, 53, 74, 90, 94, $95,102,105,106,112,113,116$, $117,123,126,132,142,153,169$, 170, 177, 181, 208

Harmand, Jules, 102, 109, 112

Ha-thach, xv

Haut-Tonkin (see Tonkin vicariate)

Hennepin, Louis, 47

highland ethnography, 97, 141, 206

highland minority(ies), ix, 18, 23, 35, 36, 38,82

highland society(ies), 20, 37, 38, 100, $103,121,123,140,153,163$

highlander(s), 14, 25, 35, 37, 103, 104, 107, 121, 125, 126, 133, 134, 148, $173,185,232$

highlands of Tonkin, 12, 16, 87, 110, $112,121,140,152,230$

Hin-y-fou, 145

historical interpretation, 98, 221

Hmong (see Miao)

Ho Chi Minh, 126

Hoa (Chinese), 33, 35

Hoa Binh province, 31, 36

Hoa-méo (Hmong), xiv

Hobbes, 59

Hoi-xuan, 142-144

Hong Kong, 160, 169, 177, 180-182, $184,205,208$

horticulture, 33, 52

Houni (Hani), 33

Hudspeth, William H., 206

Hue, 22, 25, 112, 222

Hui, 33 human races, 192

Hung Hoa (Hùng Hóa), 20, 74, 119

hunting, 52, 54, 57, 77, 156, 197

Huronia, 49, 52-57, 75, 219

Hurons, 45, 53, 57, 58

huyên, (sub-prefecture), 20, 21, 24

Huynh Huu Xúng, 23

Idiart-Alhor, Jean, 126, 180

ignorance, 8, 50, 160, 221, 223, 224

imperial expansionism, 228

imperialism, 61-63

'incidental' ethnographers, 6, 11, 65, 67, 81,233

indigenous clergy, 90

Indochina, ix, 4, 6, 13, 15, 17, 28, 30, $76,77,82,83,88,90,93,97,98$, $102,103,105,106,110,111,113$, $114,123,126,133,135,142,145$, $170,173,176,177,184-186,188$, 196, 204, 205, 218, 226, 228

Indochina population, 30

Indochina Wars, 135

Indochinese Union, 228

inductive approach, 199

Industrial Revolution, 59

Iroquois, 45, 48, 50, 52, 53, 55

Irrawaddy River, 110

Jesuit ethics, 216

Jesuit missionary, 48, 50, 219

Jesuits, 50, 51, 53, 87-90, 135, 159, $161,216,220$

Jordan, François, 120, 121

Karrer, Edouard, 120

Keso (Ké So), 74

Khmer (Kho-me), 35, 38

Khmu, 33, 132

Kho, 33

King Francis I, 45

King Louis XIII, 45

King Louis XIV, 45, 89

Kinh, xiii, 21, 23, 25, 31, 33, 35, 36, $74,88,94,95,96,98,102,104,115$, $117,119,121-126,132,179,181$

Kircher, André, xiv, 150, 158, 162, 163

Kon Tum, 36

Kouang-Si (Guangxi), 91

Kouang-Tong (Guangdong), 91

Kouy-tcheou (Guizhou), 146, 147, 149: vicariate, 145

Kunming, 100, 150, 159, 160 
La Salle expedition, 47

Lac-tho (Lac-thô), 95, 96, 98, 141

Lafitau, Joseph-François, 48, 49, 50, 51, 58, 216, 218, 221, 223

Lai Chau (Lai-chau), 22, 171, 174, 175

Lai Chau Military Territory, 175

Lai Chau, White Thai stronghold, 171

Laisi, Joseph, 120, 121

Lalemant, Gabriel, 54

Lalemant, Jérôme, 55

La-ma jen, 151, 154

Lambert de La Motte, Pierre, 89-92

land tenure, 136, 143, 196

Langson (Lang-son), 32, 175, 181, 182

language tools, 131, 134, 220

languages of Asia, 185

Lan-ngy-tsin, 150, 162

Lao, 31, 35, 36, 38, 108, 144

Lao territory, 27

Lao language, 144

Lao kingdom of Luang Phrabang, 33

Lao Kay (Lào Cai), 24, 25, 28, 36, $115,118,119,122,125,141,163$, $173-175,181$

Laos, 11, 16, 17, 28, 31-33, 82, 93, 94, 103-106, 108, 115, 116, 141, 114 $169,172,174-177,182,204,214$

Latin, 69, 90, 195, 219

Launay, Adrien, xvii, 96, 122, 153

Le Caron, Joseph, 49, 52

Le Clercq, Chrestien, 213

Lê dynasty, 20, 23, 91

Le Jeune, Paul, 56, 58

Le Roy, Alexandre, 95, 96, 198, 199, 202, 222, 227

Lê Thành Khôi, 23, 24

Leclère, 157

Leenhardt, Maurice, 5, 8, 83

Lefèvre-Pontalis, Pierre, xiii, 104-110, 189

Legendre, A.-F., 157

Legends, 49, 143, 156

Lemonnier de la Bissachère, Pierre-Jacques, 97

Les Annales de la propagation de la foi, 92, 139, 145

Les Missions catholiques, 92, 118, 123, 139, 141, 153, 163, 213, 215, 218, 222

Levi-Strauss, Claude, 8

Lezzoli, 90

Liétard, Alfred, xiv, 18, 131, 142, 150-159, 162, 164, 166, 167, 187, $189,214,215,218,225,232$

linguistic classification, 31 local authorities, 16, 46, 89, 100, 112, 114

local economy, 122, 178

local politics, 89, 90, 107

Lockhart, William, 148

Lolo, xiv, 30, 101, 108, 152, 159, 160, 163, 164, 166, 167, 191, 193, 201, 218

Lo-lo A-hi, 150, 154

Lolo-Burmese groups, 33

Long-ki, 159

Louisiana, 47, 60

Lou-lan river (Lunan), 160

Lou-mei-y, 160, 163

Louvet, Eugène, 97, 112

Luang Phrabang, 22, 33, 105, 108

Lue, 30, 31, 32, 106, 108

Lunet de Lajonquière, Émile, 15, 82, 219

Ma Touan Lin, 102

Macau, 88

Mainland Southeast Asia, 17, 18, 31, 61, 150, 153, 169, 226, 231, 233

Mainland Southeast Asian Massif (see Southeast Asian Massif)

Malay, 105, 109, 191, 193

Malinowski, Bronislaw, 10, 205

Man (Yao, Dao), 21, 31, 34, 82, 120, $125,136,137,167,171,174,175$, 178, 180, 184, 185, 189, 191, 193, 201, 208

Mandarin, 20, 21, 25, 33, 98, 99, 112, 113, 133, 148, 150, 151, 159, 185

Marguerie de la Haye, François, 52

market economy, 35, 232

Marquette, Jacques, 47

Marquis de Frontenac, 45

Martin, Jean-Marie, 141, 164

Martin, Joseph-Eugène, 158

Martinique, 220

martyrs, 72, 73, 92, 93, 96, 221

martyr room (Salle des Martyrs), 72, 221

material culture, 101, 136, 140, 155, 216

Mauss, Marcel, 8, 57, 59, 60, 205, 226

Méchet, Louis, 119

Mekong River, 27, 32, 106, 110

Méo (see Miao)

Méo rebellion, xiv

MEP (see Société des Missions Étrangères de Paris)

MEP vicariate, 16, 87, 120, 175

methodological tools, 101, 227 
Métraux, Alfred, 50

Miao (Méo, Hmong, Miaotse), 110, 146-149, 161, 164, 167, 172-178, $181,183-191,193-209,218$

Miao-Yao, 19, 21, 34, 35, 184

Middle East, 194, 195

Middle Empire, 102

Mien (see Man)

military administration, 14, 28, 117 , $118,123,175,176$

military officers, 5, 15, 102, 158, 168, $189,207,208$

Military Territories, 15, 16, 116, 117 , 124, 175, 208, 226

mineral resources, 100

Min-kia (Lo-lo group), 151, 152, 154

Minority Nationalities, 32, 37

mise en valeur, 15, 123, 228, 229

missiology, 222

Missionnaire d'Asie, 139, 168

mission civilisatrice, 228

Mission Pavie (see Pavie Mission)

missionary authors, 15, 18, 48, 81, 110 , 213

missionary education, 64, 78, 83

missionary ethnographers, 10, 18, 66, 83, 144, 210, 218, 219, 227, 232

missionary ethnography, ix, 6, 11, 17, $43,58,60,232$

missionary ethnology, 222, 223

missionary ideology, 232

missionary journals, 12, 76, 140, 142, 158, 162, 163, 166, 213, 214

missionary media, 97

missionary societies, 5, 11, 16, 71, 77, $90,92,126,135,141,175,215,217$, 224,232

missionary territories, 16, 89, 112

missionary texts, $11,12,81,121,131$, 152

missionary tradition, 132, 216

Missions Etrangères de Paris ( see Société des Missions Étrangères de Paris)

Mississipi River, 47

Môn Khmer, 31, 33

Moncay (Monkay) 28, 33, 174, 175, 182

monogénism, 149, 193, 197, 202, 207

monotheism, 199

Montagnais, 45, 54, 56

montagnard(s), 21, 22, 24, 25, 26, 28, 82, $96,108,116,120,124,134,171$

Montesquieu, 59

Montréal, 50, 53
Moréchand, Guy, 203

Morgan, Henry, 205

Morrison, Georges, 159

Motsch, Andreas, 50

Mouhot, Henri, 109

Muang Lai, 22

Müller, Max, 199

Muong, 21, 25, 30, 31, 34, 88, 95-98, $120,136,167$

Muong Sing, 108

Mus, Paul, 178, 185

Muslim, 100

Myths, 49, 143, 147, 156, 157, 190, 195,198

Nam Hou River (Nam Ou), 31, 110

Nam Ta River, 106

Nam Xang, 115

Nam-Á, 35

Nan principality, 108

Napoléon I, 225

Napoléon III, 229

Napoleon wars, 229

narrative, 48, 87, 95, 111, 139, 140, 147, 163, 186, 193, 201, 207, 213, 214,215

nationalism, 61

Native Americans, 45, 49, 51, 59

natives, $7,12,13,18,45,46,48,49$, 52-55, 74-77, 79, 119, 132, 134,

$140,157,161,165,171,181,183$, 214, 216, 217, 221, 222, 229, 231, 232

Néez, 91

Néis, Paul-Marie, 109

neo-imperialism, 61

Néron, Pierre, 118

New Economic Zones (Vietnam), 36

New France, 44, 45-52, 54, 58, 60, 135, 219,220

New Mexico, 47

Nghia-lo, 136, 137

Nguyên Anh, (see Gia Long)

Nguyên dynasty, 22, 91

Nguyên Thê Anh, 21

non-religious source(s), 132

North America, 14, 43, 48, 49

northern French Indochina, ix, 153

northern highlands, 19, 27, 29, 35, 36, 99, 103, 106

Nouvelle France (see New France)

Nung, 30-32, 36, 37, 174, 176, 182

Nyang, 31, 32 
oral history, 148, 157, 194

oral tradition, 165, 190, 194, 197, 198

orientalism, 165, 233

Ottawa, 53

Ounhi, 108

pagans, 71, 74, 119, 121, 150, 170, 217

Pai-xat, 174: settlement of, 171

Pa-Kha (today Bac Ha), xiv

Pallu, François, 89, 90

Paris, 50-52, 72, 73, 89-91, 102, 109, $113,121,135,144,145,150,158$, $169,172,178,181,198,220,221$, 223, 226

participant observation, 55, 136, 225

Patenôtre Treaty, 113

Pavie Mission, 103, 104, 109

Pavie, Auguste, xiii, 22, 27, 103-107, 110,189

Pe-Che-Ngay, village of, 151

Pels, Peter, 6, 9, 12, 63, 227

Pennequin, Théophile, 119

Perrot, Nicolas, 52

Peu-méo (see Hmong)

Phnom Penh, 105

Phongsaly, 116

Phouthai, 31

Phu (prefectures), 24

Phú Tho, 115, 117, 124

Pichaud, Mathurin, 119

Pien-Kio, 150, 151

Pigneau de Behaine, 98

Pinabel, Pierre-Charles, 98

Pin-Y, district of, 151

Plains of Abraham, 45

political organisation, 32, 34, 56

Pollard, Samuel, 206

Polo, Marco, 152

polygyny, 205

Pope Alexander VII, 89

Pope Clement XIV, 220

Pope Gregory XV, 89

priesthood, 69 ,71, 169, 182, 221

primitive religion, 200

primitive society, 59, 201

Protectorate of Tonkin (Protectorat du Tonkin, see Tonkin)

Protestants, 44: Protestant ministers, 68: Protestant missionaries, 73, 206

Prussia, 228, 229

Puginier, Paul François, xiii, 74, 87, $111-115,133,230$
Québec, 44-46, 52-54, 56

Rabinow, Paul, 231

race, 20, 59, 100, 101, 137, 149, 150, 186, 187, 190, 192, 193, 198, 200, 201

Ramond, Paul-Marie, xiii, xiv, xv, 77, $115-117,121,123,125,132,133$, $135,169,174,179,181,182$

rationalism, 217

Raynal, Guillaume-Thomas, Abbé de, 47

rebellions, 22, 76, 100

Red River (Sông Hông, Fleuve Rouge), 16, 20, 24, 32, 38, 91, 99, 106, 113-114, 116-120, 122, 124

Red River delta, 11, 19, 21, 25, 27, 28, $33,35,38,75,87,94,95,112,118$

Red Thái, 30, 31, 143

Regent Tôn That Thuyet, 113 (mettre les caractères vietnamiens)

Reinach, Salomon, 199

Relations des fésuites en Nouvelle France (Jesuit's Relations), 51, 52, 54, 57, 58, $76,135,220$

religious authorities, 49, 134

religious censorship, 221

religious communities, 46

religious education, 78, 79, 158, 221, 230

religious establishment, 73, 127, 131, 140, 145, 217

religious ethnographers, 65, 224

religious ethnology, 222, 223

religious persecutions, 93

religious schools, 53

Republican ideals, 4, 228, 229

revolution, 59, 60, 91, 93, 166, 228, 229, 233

rituals, 26, 49, 56, 138, 197

Robert, Ambroise, 118, 119

Robert, Jean, 118

Rocher, Emile, 28, 100-102, 157, 158

Roman Catholic Church, 89

romanisation, 185, 191

Rousseau, Jean-Jacques, 59, 65, 66, 223

Roux, Henri, 15, 82, 204

Roux, Vincent, 164

Sagard-Theodat, Gabriel, 48-52, 54, 56,216

Saigon, 53, 105

Sainson, C., 157, 158 
Saint Lawrence River, 44

Sainte-Croix Island, 44

Salemink, Oscar, 6, 63, 227

Sani, 160, 165, 166

Sapa (see Chapa)

Sarraut, Albert, 228

Sault Saint-Louis, 50

savages, 29, 44, 46, 47, 50, 51, 69, 96, $138,216,218,221$

Savina, François-Marie, 121, 125, 131, 152, 163, 167-209, 214, 215, 218, 223, 225, 230, 232

Schmidt, Wilhelm, 5, 141, 158, 214

Schoeffler, Augustin, 117, 221

Schotter, Aloys, xiv, 142, 145-150, 189, 206, 207, 214, 232

Schrauwers, Albert, 3

scientific community, 215, 216

scientific intention, 58, 214

scientific longing, 216

scientific role of missionaries, 222

scientific thinking, 224

Second Empire (France), 229

Second World War, 126

secular sources, 219

seminaries, 68-71, 122, 224

Seven Year War, 60, 220, 228

shamanism, 199, 203

Shan, 108

Siam, 88, 90, 92, 103, 106, 146

Siberia, 193, 194

Sichuan, 77, 153, 156, 158, 159, 206

sinologist, 102, 165

Sino-Tibetan language family, 33

Sioux, 47

Sip Song Chau Tai, 22, 27, 106, 116, 171

Sip Song Phan Na, 106

Société des Missions Etrangères de Paris

(MEP) , 13, 16, 29, 65, 69, 70, 87, 90, $153,213,230$

Society for the Observation of Man (Société des observateurs de l'homme), 225

Society of Jesus (see Jesuits)

Society of the Divine Word, 5, 141

Son-Tay, 91

Song Ma (River Ma), 32

Song-chay, parish of, 118

Southeast Asian Massif, 18, 20, 26, 28, 91, 99, 102, 106, 145, 153, 167, 195 southwest China, 21, 32, 131, 142, 148, 159, 184, 189, 206, 219, 233

Spanish Dominicans, 87, 94, 219

Stieng, 191, 193

Stipe, Claude, 9
Stocking, George W. Jr., 10, 60, 63, 109

subjectivity, 14, 65

Swain, Margaret Byrne, xi, 4, 160, 163, 165, 166, 233

Tadoussac, 44

Tahiti, 220

Tai language, 145,170

Tai speakers, 24, 30, 32, 33, 34, 108, 143, 145, 184

Tai Youne, 108

Tai-Kadai, (Thai-Kadai), 18, 31, 35, 36

Tali Lake, 151, 159

Taoism, 33

Tatars, 193

taxation, 20, 33, 76, 143, 176

Tay (Tày, Thô), 22, 25, 30-32, 36, 37, 120, 170, 171, 173, 174, 182, 183, 185, 208

Tchao-Tong (today Zhaotong), district of, 151

Tchen-Fong-Shan, 151

Terrasse, Jean, 159

Thai (Thái), 22, 31, 32, 36, 108, 120, 125, 143, 167, 191: Black Thai, 30, 31, 108: White Thai, 171, 176: Red Thai (Thai Daeng), 143: Thái Neua, 31: Thái Phong, 31

Thai domain, 120

Thai Lao (Thai Laotien), 31, 32

Thái Lue, (see Lue)

Thái Nguyên region, 22

Thailand, 19, 32, 110

Thanh Hóa , 36

Thâp-châu, 20

Thay, 137, 143, 144

Thérien, Gilles, 56

Theurel, Joseph, 97, 113, 115

Thibetans, 193

Third Military Territory, 116, 172, 174, 175, 208

Third Republic (France), 4, 13, 93, 110, 133, 227-229

Third World, 61

Thô (see Tay)

Thomas, Nicholas, 207

Thu-Lê, 137

Tibeto-Burman, 30

Tiele, Cornelis Petrus, 199

Tien-yen, 174

Tilburg (Netherlands), 223

tobacco, 49,156

tông (cantons), 24

Tonkin, $4,12,14,16,18,19,21,22$, 
24, 25, 27, 28-35, 51, 53, 74, 75, 77, 81, 82, 87-89, 91-106 111-117, 119-126, 132-135, 137, 139, 144, $145,153,159,162,163,170$, 173-177, 179, 182-184, 189, 198, 202, 204, 209, 213, 214, 219

Tonkin's vicariates, 90, 94, 95, 110 , $114,115,117,121,122,126$, 131-134, 141, 142, 168-170, 179, 181

T'oung Pao, 154

trade, 20, 25, 33, 34, 36, 45, 52, 53, 65, 66, 77, 101, 105-109, 196

Tran (prefectures), 23, 24

Trenta Council, 89

tribute, 22, 96, 108

Tri-châu, 21

Trigger, Bruce, 52

Tri-huyên, 21

Tring authorities, 89

Trivière, Léon, 171, 173, 174, 209

Trois-Rivières, 53

Trudel, Serge, 213

Tsin-chan-keou, 162, 163

Tu-duc, 23

Tuyên Quang, 28, 116-121, 124,

Tylor, E.B., 205

upland Mainland Southeast Asia (see Mainland Southeast Asia)

upland Tonkin (see Tonkin)

upper northern Laos (see Laos)

Upper Tonkin vicariate (see Tonkin Vicariate)

Urry, James, 224

van Gennep, Arnold, 50

Van Lang, kingdom of, 20

Vandaële, Georges, xv, 121, 123-126, 134, 199

Vénard, Théophane, 221

vernacular languages, 55, 74, 75, 120, $132,136,145,165,175,180,190$, 214, 233

Versailles Treaty, 45

Ve-tse (Lolo village), 163

Vial, Paul, xiv, 4, 16, 18, 77, 102, 131, $150,152,153,154,158-168,183$, $187,189,206,214,215,218,223$, $230,232,233$

vicar apostolic, 16, 75, 90, 94, 112, 113, 114,115
Viel, Nicolas, 49, 52

Viet, 19, 21, 24, 25, 30, 31, 33, 34

Viet-Muong, 30

Vietnam, 17, 20, 22-24, 26, 31, 34-38, 72, 87, 88, 91-93, 98, 104, 112, 115, 117, 126, 183, 222: Northern Vietnam, ix, 7, 11, 14, 17-20, 28, 32-34, 140, 176

Vietnam War, 61, 62

Vietnamese language (Vietnamien) 31, $132,170,191$

Vietnamese ethnologists, 35, 37

Vietnamese priest(s), 96, 119

Vinh-tuy (mission), 170-175, 180, 181, 207, 208

Voltaire, 59, 223

von Luschan, F., 205

West Tonkin vicariate (see Tonkin vicariate)

Western anthropologists, 7, 35, 37

Western ethnographers, 5, 37

Western ethnology, 39

wet rice cultivation, 33

White Tai, 103, 106-108

Wisconsin, 47

Wong, Gaston (General), 178

$x \tilde{a}$ (communes), 24

Xieng Khong, 108

Xu Đoài district, 117, 118

Yang-pi district, 159

Yao (see Man)

Yen-bai (Yên Bái), 28, 117-120, 122, 124,136

Yên Tap, parish of, 119

Yi (Lo-lo group), 151

Y-jen (Tai-speaking group), 146, 147, 156

Youne, 108, 109

Yunnan, ix, 6, 11, 14, 16-18, 24, 25, 28, 32, 33, 77, 91, 100-101, 105, $106,110,116,122,150,151$, $153-155,157,159,161,163,166$, 167, 174, 184, 214, 218, 219, 225, 230

Yunnan-sen (today Kunming), 100

Zhuang, 32 